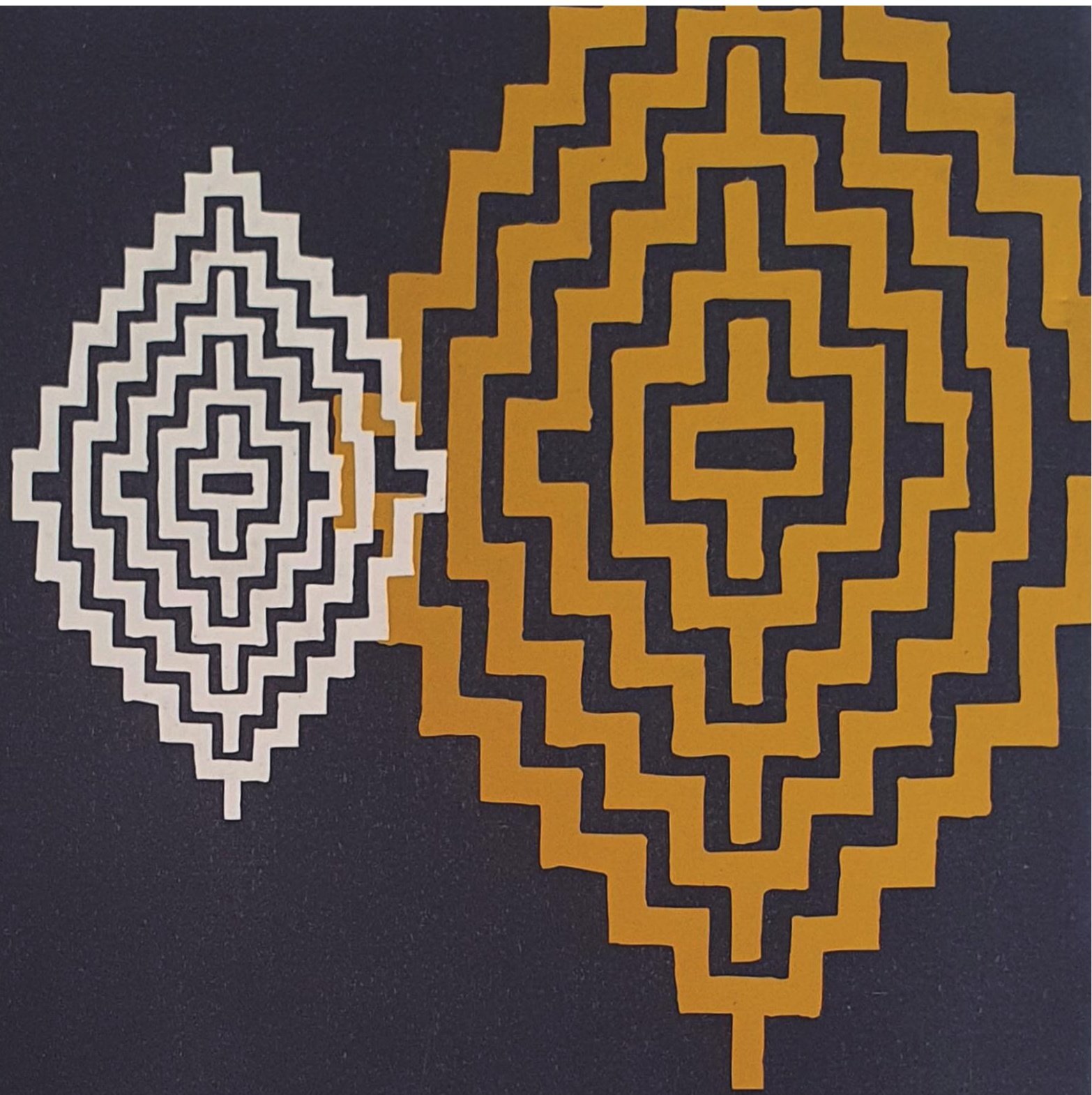

Poder, Hierarquia e Reciprocidade: saúde e harmonia entre os Baniwa do Alto Rio Negro

Luiza Garnelo 


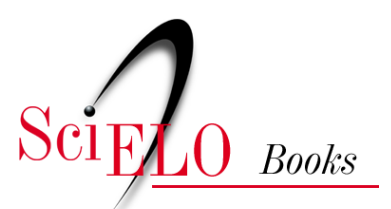

\title{
Poder, hierarquia e reciprocidade saúde e harmonia entre os Baniwa do Alto Rio Negro
}

\author{
Luiza Garnelo
}

\section{SciELO Books / SciELO Livros / SciELO Libros}

GARNELO, L. Poder, hierarquia e reciprocidade: saúde e harmonia entre os Baniwa do Alto Rio Negro [online]. Rio de Janeiro: Editora FIOCRUZ, 2003, 257 p. Saúde dos povos Indígenas collection. ISBN: 978-65-5708-012-2. https://doi.org/10.7476/9786557080122.

International license.

Todo o conteúdo deste trabalho, exceto quando houver ressalva, é publicado sob a licença Creative Commons Atribição 4.0.

Todo el contenido de esta obra, excepto donde se indique lo contrario, está bajo licencia de la licencia Creative Commons Reconocimento 4.0. 

Poder, Hierarquia e Reciprocidade: saúde e harmonia entre os Baniwa do Alto Rio Negro 


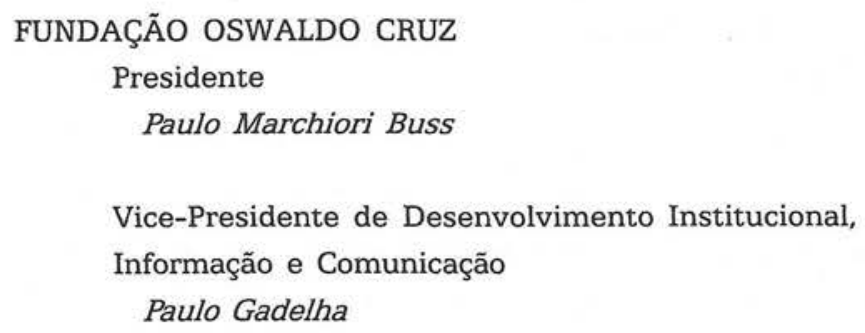

Vice-Presidente de Desenvolvimento Institucional, Informação e Comunicação Paulo Gadelha

\section{EDITORA FIOCRUZ}

Coordenador

Paulo Gadelha

Conselho Editorial

Carlos E. A. Coimbra Jr.

Carolina M. Bori

Charles Pessanha

Jaime L. Benchimol

José da Rocha Carvalheiro

José Rodrigues Coura

Luis David Castiel

Luiz Fernando Ferreira

Maria Cecília de Souza Minayo

Miriam Struchiner

Paulo Amarante

Vanize Macêdo

Coordenador Executivo

João Carlos Canossa P. Mendes

Coleçāo Saúde dos Povos Indígenas

Editores Responsáveis: Ricardo Ventura Santos

Carlos E. A. Coimbra Jr. 
Poder, Hierarquia e Reciprocidade: saúde e harmonia entre os Baniwa do Alto Rio Negro

Luiza Garnelo 
Copyright (c) 2003 da autora

Todos os direitos desta edição reservados à

FUNDAÇÃO OSWALDO CRUZ / EDITORA

ISBN: 85-7541-033-4

Capa

Danowski Design

Projeto gráfico e editoração eletrônica

Angélica Mello

Preparação de originais e revisão

Marcionílio Cavalcanti de Paiva

Copidesque

Simone Brantes

Catalogação-na-fonte

Centro de Informação Científica e Tecnológica

Biblioteca Lincoln de Freitas Filho

G234p Garnelo, Luiza

Poder, hierarquia e reciprocidade: saúde e harmonia entre os Baniwa do Alto Rio Negro. / Luiza Garnelo. Rio de Janeiro: Editora Fiocruz, 2003.

260p.

1. Índios Sul-Americanos. 2. Saúde.

CDD- 20.ed. - 980.41

2003

EDITORA FIOCRUZ

Av. Brasil, 4036 - $1^{2}$ andar - sala 112 - Manguinhos

21040-361 - Rio de Janeiro - RJ

Tels.: (21) 3882-9039 e 3882-9041

Telefax: (21) 3882-9006

http://www.fiocruz.br

e-mail: editora@fiocruz.br

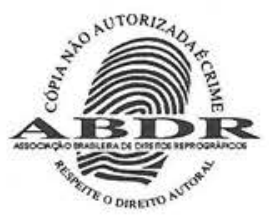


Para Taui,

com todo meu amor. 



\section{Sumário}

Prefácio

Parte I - Mitologia, Política, Gênero e Geração

1. Os Sentidos Cósmicos e Políticos da Produção e Reprodução da Doença ............. 29

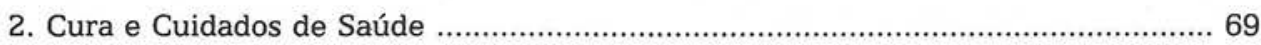

3. Doença, Poder e Disputas no Dia-a-Dia: o a posteriori da doença ........................ 81

Parte II - Política, Moral e Legitimidade no Mundo Aldeão

4. Hierarquia, Guerra, Alteridade e Poder na Ancestralidade

5. Mundo Baniwa: o ontem no hoje 135

6. Organizações de Base do Içana e Aiari ....

Parte III - A Politização da Etnicidade

7. Mundialização, Globalização e Etnicidade 177

8. Movimento Indígena no Cenário Baniwa 203

Conclusão 225

Anexo 237

Referências Bibliográficas 241 



\section{Prefácio}

Coerente com os modelos baniwa de organizar o universo, o livro de Luiza Garnelo, produto de sua tese de doutorado na Universidade Estadual de Campinas (Unicamp), trabalha com três círculos concêntricos - correspondentes às três partes que o compõem - e as conexões entre eles. O primeiro, e o mais fundamental, se refere aos sentidos que os Baniwa atribuem ao seu mundo, o cosmos, e o lugar central que a doença ocupa nele. É a parte mais densa do livro, mas com bastante habilidade a autora apresenta ao leitor esse complexo mundo. Não é uma descrição pura e simples do cosmos em sua relação com os mitos de criação, pois ela mostra que existe uma profunda conexão entre os atos de criação ou transformação pelos seres primordiais, as divindades, e a política. A criação envolve a política; todo ato de criação envolve - como se fosse em troca - um ato de destruição, o lado negativo que geralmente é manifesto na doença. Esta foi introduzida no mundo nos primórdios da humanidade e é inerente à natureza da existência humana. A própria divindade, chamada o Senhor das Doenças, é ao mesmo tempo a fonte e origem dos instrumentos sagrados mediante os quais a vida se reproduz e pelos quais os humanos podem se destruir através da doença, geralmente atribuída à feitiçaria. Todos os atos de criação elaborados nos mitos acontecem por intermédio de enredos políticos tramados entre os atores. São inúmeras as histórias de 'tribos' primordiais que ameaçam destruir a ordem e a harmonia desejada pelo Criador ou tentam impedir que tal ordem se reproduza.

O drama cosmogônico que acaba criando o eixo vertical do cosmos, associado à réprodução da ordem, é traduzido no mundo humano nas histórias políticas, relações de guerra, no comércio e matrimônio, os quais definem o eixo horizontal do mundo baniwa, as relações entre as fratrias e os sibs Baniwa e outros povos - os Tukano, os Maku, os Maquiritare e outros do noroeste amazônico (alguns desses povos, como os Maquiritare, vivem na Amazônia colombiana). Do mesmo modo que, no eixo vertical, a identidade humana só se define através de uma tensão constante com a alteridade, no eixo horizontal das relações entre grupos atuais, a história consiste de tramas políticas com os 'outros.' Esses 'outros' abrangem desde os aliados e afins potenciais até os inimigos com quem faziam a 
guerra. Os afins potenciais representam uma ameaça particularmente ambígua porque, como ensinam os mitos, podem matar os parentes por meio de feitiçaria e doenças, mas, no entanto, são a fonte de bens e descendentes. São um mal necessário da vida.

Na segunda parte do livro, Garnelo analisa a organização política baniwa, começando com uma breve discussão das instituições tradicionais como a guerra marcante na memória baniwa sobre o seu passado, e na memória de povos vizinhos sobre os Baniwa -, os líderes de guerra e chefes de aldeias, a centralidade da dinâmica entre a organização hierárquica dos sibs - característica também da organização sociopolítica dos povos tukano-falantes da região - e uma ética cotidiana de igualitarismo. A história recente modificou o funcionamento dessa dinâmica, particularmente em relação à estrutura interna da autoridade nas comunidades a qual é definida, na maioria, pela organização evangélica. Finalmente, ela atualiza essa discussão considerando o movimento associativista que, desde os anos 80 , tem definido a configuração política da região com mais de 30 associações políticas locais, ou 'organizações de base', várias das quais entre os Baniwa do Içana e Aiari. Focaliza atenção, ainda, em uma das associações mais bem-sucedidas da região, com a qual ela colabora desde a sua criação. É esse trabalho que lhe permite fazer uma análise extremamente interessante e detalhada do dia-a-dia das associações e de seus líderes - uma contribuição original e valiosa a nossa compreensão do movimento indígena. Quais os problemas que as lideranças enfrentam? Quais as barreiras que precisam ser superadas? Como eles conseguem construir novos espaços de intermediação entre os Baniwa e os Brancos? Como lidam com as armadilhas do maquinário do Estado e quais os riscos pessoais que correm? As próprias lideranças traçam paralelos entre as lutas que enfrentam para conseguir uma vida melhor para o seu povo e as lutas do Criador que, nos tempos míticos, teve de enfrentar inúmeras armadilhas e até a morte nas mãos de outras tribos. $\mathrm{O}$ Mito é sempre atualizado na política contemporânea. Os depoimentos de algumas lideranças são eloqüentes nessas comparações entre as habilidades e a 'esperteza' dos heróis míticos e o que é exigido das lideranças atuais.

Novamente, a doença e a cura representam o processo crítico para a definição de relações de poder. As doenças, e mais especificamente aquelas provocadas pela ação humana (a feitiçaria), são mecanismos normativos para a regulação de poder. As lideranças, portanto, se colocam numa posição de extrema vulnerabilidade, como os profetas do passado e como os heróis míticos, pois são mais sujeitos aos ataques dos inimigos que procuram nivelar, senão inverter, as relações de poder. Por isso, os Baniwa se encontram numa 'encruzilhada da história', como diz a autora: para conseguir os recursos que por tantas gerações lhes foram negados, precisam afrouxar as normas de nivelamento ou igualitarismo, pois as novas lideranças precisam de espaço para negociar as mudanças ou correm o risco de sacrificar as lideranças. 
A Parte III analisa o terceiro círculo, o de maior abrangência, definido pelo processo atual de globalização em que o movimento indígena está inserido. A história baniwa ensina que eles começaram a ser envolvidos em sistemas políticoeconômicos maiores logo no início do contato com os Brancos - o sistema de escravidão no século XVIII, os dois ciclos da borracha nos séculos XIX e XX, além de uma série de outras formas de extrativismo para mercados externos. Tais ciclos deixaram-nos em situações de extrema dependência até a metade do século XX, quando a maioria deles se converteu ao protestantismo evangélico, resultado da Cruzada de Evangelização Mundial (World Evangelization Crusade), efetuando relativa ruptura com os processos colonizatórios anteriores. A 'mundialização', portanto, não é novidade para eles. Nova é a postura das lideranças atuais buscando assumir o controle sobre sua participação nesse processo, afirmando a sua etnicidade no contexto global. $O$ texto mostra grande habilidade em analisar diversos aspectos da nova politização baniwa, principalmente na área da saúde.

Com isso, os círculos se fecham em torno da questão da saúde, esfera em que Luiza Garnelo tem atuado na região do Alto Rio Negro desde os anos 90, com o programa Rede Autônoma de Saúde Indígena da Universidade Federal do Amazonas, vinculando o presente mais uma vez com os fundamentos míticos, através da noção de poder.

\section{Robin M. Wright}

Doutor em antropologia, professor do Departamento de Ciências Sociais da Unicamp, pesquisador dedicado ao estudo da cultura baniwa 

Este livro é uma versão ligeiramente modificada de minha tese de doutorado defendida na Unicamp em 2002. Ele representa uma busca de apreender diversos aspectos do mundo baniwa, aparentemente díspares mas que estão, de fato, interconectados na vida cotidiana dessas pessoas, cuja trajetória me esforcei para registrar nas páginas que se seguem. A convivência com o mundo baniwa é sempre uma vertiginosa entrada num portal misterioso que há vários anos tento desvendar. Nesse período, mais do que buscar histórias de ancestrais mortos, tenho tentado entender como essas antigas idéias influenciam a vida dos vivos e como tais existências vão remontando o mosaico dessa fascinante tradição.

Nessa trajetória me tornei profunda admiradora da cultura baniwa e de seu modo estóico de vida, cujos precisos contornos posso apenas entrever. Também fiz diversos amigos, dentro e fora do mundo baniwa, mas todos interessados em contribuir para a melhoria das condições de vida desse e de outros povos indígenas. Assim, sou profundamente grata aos meus amigos baniwa, em especial a André, Bonifácio, Gersen, Irineu, Sr. Valentim e seu filho Roberto Paiva, com quem travamos longas conversas e produtivas parcerias em atividades de apoio aos Baniwa.

No mundo não-indígena também são muitos os que me auxiliaram nessa tarefa. Dentre esses quero mencionar meu orientador, professor Robin Wright, e também Carlos Coimbra, Ricardo Ventura, Jean Langdon, João Pacheco de Oliveira Filho, Geraldo Andrello, Almir Jr., Maria Helena Ortolan Matos, Márcio Silva, Jorge Guerra, Raimunda Silva, Elda Rizzo, Inesita Araújo, Fábio Vaz, Gedeão Timóteo, Dominique Buchillet e Beth Conklin.

Agradecimentos institucionais à Capes, Universidade Federal do Amazonas, Projeto Rasi, ao convênio CNPq/IRD/ISA/Projeto "Fatores sócio-culturais e econômicos de risco para HIV e tuberculose na região do Alto Rio Negro (Amazônia brasileira)" e ao Centro de Pesquisas Leônidas \& Maria Deane/Fiocruz/Amazônia. Por fim, uma referência especial a meus pais, minha filha Taui, ao meu companheiro Brandão, a Sully, D. Rosária e Adriana, que não apenas suportaram minhas ausências e a eterna falta de tempo, mas também me estimularam e me apoiaram com seu carinho e presença constantes. 



\section{Introdução}

Produto de uma pesquisa conduzida entre os indígenas do grupo Baniwa, no Alto Rio Negro, noroeste da Amazônia brasileira, este trabalho toma as representações de doença, práticas de cura e movimentos reivindicatórios por melhoria das condições de vida e saúde, como ponto de partida e eixo principal de uma discussão sobre o exercício do poder político num contexto de relações entre os mundos indígena e não-indígena. Por essa via se busca analisar os modos pelos quais produções sociais e culturais trazidas pelo processo colonizatório se constituíram historicamente no Alto Rio Negro e como se articulam com as concepções indígenas de autoridade, legitimidade, de doença e de cuidados de saúde, aqui entendidos como formas possíveis da expressão do poder nas culturas locais.

O Alto Rio Negro é uma região que congrega diversos grupos étnicos que mantêm interações sociais, políticas e religiosas entre si, configurando-se como um sistema cultural que guarda muitas características comuns, como os rituais de passagem, a estrutura social, regras de matrimônio etc. A diversidade lingüística é um dos traços marcantes na organização social rionegrina e reflete variações culturais expressas na distribuição espacial dos grupos de parentesco, no acesso a recursos naturais e na produção de cultura material e simbólica (Hugh-Jones, 1979a, 1979b; Kock-Grümberg, 1995).

Em termos geopolíticos a área é subdividida de acordo com seus principais cursos de rio, os quais equivalem aos sítios ancestrais de moradia de grupos étnicos específicos (Vide anexo, mapa 1). Assim, temos o Uaupés com seus principais afluentes; o Tiquié, congregando os grupos de língua Tukano; o Papuri, onde se localizam ainda hoje as moradias dos Tariano, sociedade de origem Arawak que adotou o Tukano como língua-mãe, além dos grupos Maku. ${ }^{1}$ A calha do Rio Negro tem sido a moradia dos grupos Baré; seu afluente Xié abriga os Warekena, Arawak falante, ao passo que no Içana e seus afluentes Aiari, Quiari e Cuiari residem os Baniwa. Esta subdivisão geográfica das sociedades locais tem orientado o processo colonizatório desde os seus primórdios até os dias atuais; mesmo tendo havido uma considerável mudança nos padrões indígenas de moradia, ela permanece influenciando na forma de atuação das organizações indígenas e das agências de governo. 


\section{Relações interétnicas no processo colonizatório - panorama sucinto}

Ao longo do processo colonizatório, os grupos rionegrinos têm interagido com diversos agentes de contato, como os inspetores de índios, os missionários, seringalistas da borracha e o Estado brasileiro, através do Serviço de Proteção ao Índio (SPI), Fundação Nacional do Índio (Funai) e dos militares. Mais recentemente o cenário se enriquece com a chegada de outros interlocutores do poder público, como o Ministério da Saúde, universidades, órgãos de fomento ao desenvolvimento agrícola, secretarias de saúde e de educação, além de organizações não-governamentais de apoio à causa indígena e/ou voltadas para a preservação ambiental.

A história das relações interétnicas é uma sangrenta sucessão de violências que se iniciam no século XVIII com o comércio de escravos e os conseqüentes descimentos feitos pelos portugueses, na busca de mão-de-obra capaz de executar as atividades necessárias ao estabelecimento de suas possessões territoriais. As expedições de captura, organizadas tanto por portugueses quanto por espanhóis, aliadas à eclosão de violentas epidemias e à exacerbação das relações guerreiras entre os grupos indígenas, dizimaram violentamente a população.

Na segunda metade do século XIX, instala-se o boom da borracha com o estabelecimento de seringais de extração e postos locais de armazenagem e comercialização das pélas. Os patrões da borracha, brasileiros e colombianos recrutavam a mão-de-obra indígena por intermédio de expedientes como o aliciamento, o endividamento forçado (aviamento), a alcoolização e a violência franca, num sistema de relações que ficou conhecido como 'regime do barracão'.

Em 1914, os salesianos chegam à região dispostos a obter sucesso onde os outros fracassaram; encontraram um cenário desolador de miséria, morte, doença e medo, o que deve ter contribuído para uma melhor aceitação de seu projeto catequético pelos índios. Os preceitos missionários se assentavam no pressuposto da imoralidade, ignorância, superstição e atraso dos índios, demandando um projeto civilizatório ativamente construído por meio da escolarização, da imposição progressiva da religiosidade cristã/católica e do uso de vestimentas ocidentais, da destruição das malocas, desmoralização dos seus rituais e proibição do uso de línguas indígenas dentro dos internatos (Oliveira, 1995).

No seu longo período de atuação, a missão católica desenvolveu uma imagem profundamente depreciativa da cultura indígena. Os jovens precocemente recolhidos aos internatos conviviam diuturnamente com um conjunto sistemático de mensagens que desvalorizavam a cultura indígena, ao associá-la à incapacidade, à sujeira e à selvageria. Depoimentos de ex-internos demonstram uma internalização gradativa desta auto-imagem depreciada, gerando-se um terreno 
propício para um abandono 'voluntário' dos demarcadores culturais mais evidentes, como os rituais de passagem, e para a negação da identidade étnica, vista como barreira na superação das desigualdades sociais a que os índios estavam submetidos. A eliminação da etnicidade passou a ser vista, por muitos dos egressos das escolas salesianas, como uma forma eficaz de supressão do estigma gerado pela condição indígena e como meio de alcançar lugares privilegiados na sociedade nacional. Tais idéias ainda hoje são encontradas entre as gerações que estão nas faixas etárias entre 40 e 70 anos, em todo o Alto Rio Negro.

A estas condições subjetivas associava-se a falta de alternativas de emprego e geração de renda, pois a decadência do extrativismo da borracha não deu lugar a outro tipo de atividade econômica que pudesse suprir as necessidades da população local. A persistência da extração de outros produtos da selva, como o chicle e a piaçava, não era capaz de gerar renda minimamente compatível com as expectativas das famílias, perpetuando a desagregação familiar, endividamento e deslocamento forçado dos homens para longe das suas aldeias. Os diversos ciclos econômicos promoveram uma integração subalternizada dos índios à economia de mercado e criaram a necessidade de produtos manufaturados fora das terras indígenas, tornados imprescindíveis à vida cotidiana. O sistema de aviamento se manteve em lenta decadência até o fim da década de 70, quando a geopolítica da ditadura militar sacudiu novamente a região com suas propostas integracionistas.

A atuação do órgão indigenista, presente na região desde o início do século XX, através do Serviço de Proteção ao Índio (SPI), foi marcada pela triste trajetória do órgão, conivente com os abusos dos seringalistas, quando não pela subordinação direta dos índios ao chefe de posto. Debatendo-se entre a inoperância e a necessidade de gerar receitas próprias para sua sustentação local - o que obviamente só poderia ser obtido pela extração de produtos através de mão-deobra indígena -, o SPI entrou em confronto com a missão salesiana e, após uma troca de acusações recíprocas, foi vencido por ela. O órgão indigenista se retirou na metade da década de 50, deixando o território livre para os católicos até a década de 70, quando a Funai revitalizou os postos outrora existentes (Oliveira, 1995).

A conjunção das iniciativas missionárias e as transformações da vida econômica tiveram entre suas conseqüências a ruptura de várias estratégias tribais de cooperação, tornando a família nuclear o módulo primário de desenvolvimento de atividades econômicas e comprometendo a capacidade produtiva num ecossistema caracterizado pela escassez de alimentos.

Os anos 80 trouxeram novos problemas para a população rionegrina. Embora reconhecidas como área indígena, suas terras não estavam demarcadas. Em 1983, a elevação do preço do ouro no mercado internacional propiciou a invasão da região por garimpeiros, gerando em conseqüência a mobilização de duas 
empresas mineradoras (Goldamazon e Paranapanema) que detinham a licença para prospecção mineral na região e iniciaram uma movimentação para expulsar os garimpeiros não-indígenas que lá atuavam. O clima era de conflagração geral, com as duas empresas disputando entre si, mas aliadas contra os garimpeiros autônomos e contra os direitos indígenas. Na área baniwa, a empresa Goldamazon controlava não apenas a licença para minerar no território indígena, mas, apoiada pelas autoridades estaduais, estabeleceu um sistema de bloqueio ao trânsito fluvial, inclusive indígena, no Rio Içana.

Ao longo da década de 80 conjugaram-se os interesses das empresas com os das autoridades locais e das políticas militares de ocupação da Amazônia, cuja maior expressão foi o projeto Calha Norte, que revitalizou o projeto colonizatório no Alto Rio Negro, estimulando a ocupação das fronteiras por empresas e colonos não-indígenas, implantando uma malha viária e abrindo as terras de ocupação ancestral à exploração econômica de solo e subsolo. Os índios com seus assessores, bem como a Funai, elaboraram diversas propostas de demarcação, seja na forma de uma reserva única ou de áreas contíguas, sem lograr resultados satisfatórios.

O órgão indigenista corroborou, por fim, as propostas de expropriação das terras homologando finalmente, em 1989, uma demarcação de três áreas indígenas contíguas por entre as quais as 'florestas nacionais' estariam abertas à exploração econômica, prejudicando gravemente os direitos dos grupos Maku, Baniwa e parte dos povos Tukano. Apesar das tentativas de alguns antropólogos do órgão, que tentaram obter uma demarcação contínua ou, no mínimo, mais ampliada, a Funai se curvou às determinações do Conselho de Segurança Nacional, garantindo regalias (ilegais) para as mineradoras na região (Buchillet, 1991a, 1991b).

Os índios também se dividiram politicamente quanto às iniciativas dos militares. Sua divisão política pode ser creditada à omissão do órgão indigenista, à falta de perspectivas de desenvolvimento econômico e à ausência de um projeto político próprio que aglutinasse de forma construtiva suas motivações e necessidades. A ruptura das antigas formas de poder político e ritual, produzida pela ação missionária, deixava as chefias locais imersas numa incompreensão difusa sobre as formas de operar das instituições do mundo dos brancos. O jogo de decretos, portarias e comissões encobria um conjunto de interesses obscuros e muito mais amplos que o viver cotidiano indígena, deixando as chefias sem as informações necessárias à tomada de decisão. As informações localmente disponíveis eram insuficientes para a apreensão de idéias tão abstratas quanto florestas nacionais, 'segurança nacional', 'terra indígena' etc. Além disso, a tomada de decisões de alcance supralocal, como a demarcação de terras para todo o Alto Rio Negro, era uma experiência nova para agentes políticos acostumados a entabular relações e negociações apenas no âmbito do parentesco e do conjunto de aldeias onde viviam. 
Some-se a isso a já citada incorporação de uma depreciação da sua própria etnicidade pelos membros mais escolarizados. Estas pessoas, a princípio as mais habilitadas a compreender as nuances envolvidas nestas delicadas negociações, tendiam paradoxalmente a uma maior permeabilidade às propostas desenvolvimentistas dos militares, demonstrando a difusão de um senso comum evolucionista na vida cotidiana. Além disso, as gerações mais jovens não tinham vivenciado a violência gerada pela convivência cotidiana com frentes econômicas em suas terras. O terror dos descimentos e do regime de barracão surgia mais como uma lembrança, tornada viva apenas pelos relatos dos velhos, do que como uma experiência concreta; aparentemente faltavam aos mais jovens elementos para apreender de imediato a magnitude da ameaça representada pela disruptiva intervenção do Calha Norte. A perspectiva de geração de renda e do estabelecimento de políticas sociais que favorecessem o acesso a direitos anteriormente negados parecia mais atraente do que a preservação de um modo de vida, encarado naquele momento como um entrave à modernização da sociedade.

Como se disse antes, não havia consenso estabelecido e a expressão pública indígena através de documentos e pronunciamentos, feitos na época, mostrava uma polifonia eivada de contradições; o quadro era agravado pela ausência de um contradiscurso sistemático e eficiente na valorização da etnicidade e/ou das idéias democráticas em geral, pois no cenário nacional o País ainda convalescia das mazelas da ditadura e os movimentos etnopolíticos mal iniciavam seus primeiros passos. Nos fóruns indigenistas ainda não se legitimara a idéia de que os índios podiam falar por si e por seus interesses, prevalecendo a noção de que tinham de ser representados por 'autoridades' não-indígenas, fossem elas missionários, antropólogos, funcionários do órgão indigenista e outros atores quaisquer, tornando o controle indígena sobre seu próprio destino uma impossibilidade.

Num cenário tão desfavorável, é de se perguntar como essas iniciativas semi-ordenadas possibilitaram a instituição da Federação das Organizações Indígenas do Rio Negro (Foirn) em 1989, inaugurando a era do movimento indígena na região e criando um canal onde as vozes indígenas pudessem expressar suas prioridades e contradições. Do fim da década de 80 até o momento atual, a Foirn vem aglutinando as iniciativas de revitalização da etnicidade, tendo conseguido inclusive reverter a desastrosa demarcação e obter por meio de recursos judiciais uma demarcação contínua, tal como inicialmente pretendido.

Construída ao longo de muitas décadas, essa é a cena social na qual hoje vivem os Baniwa - objeto deste estudo - que mantém relações regulares com as instituições de saúde, não apenas como usuários, mas como agentes de saúde, conselheiros e gerentes indígenas de convênios firmados com o Ministério da Saúde, participando de forma ativa da construção de um subsistema de saúde dirigido aos povos indígenas do País. 


\section{Os Baniwa}

O grupo étnico Baniwa ${ }^{2}$ tem, em território brasileiro, uma população de aproximadamente 4.650 indivíduos, distribuídos em 94 assentamentos ao longo dos rios Içana e Aiari, tributários do Rio Negro, em área de fronteira com a Colômbia (ISA/Foirn, 1997). Seus membros partilham a história comum dos povos rionegrinos, mas as singularidades culturais do grupo e o processo coletivo de conversão à religião evangélica lhes conferem características não encontradas em outras subregiões do Alto Rio Negro. Dentre elas destacamos a existência de um milenarismo, estudado por Wright (1992c, 1999b) e por Wright \& Hill (1986), com tendência a eclosões periódicas cujos surtos convulsionavam a região, gerando mobilização interna contra o violento processo colonizatório, assim como reação das autoridades encarregadas de controlar a mão-de-obra indígena.

Embora tenham sofrido - como os outros povos da região - a intervenção dos salesianos, os Baniwa foram profundamente influenciados por uma missionária evangélica, a americana Sophie Muller, que em 1948 penetrou no Içana brasileiro para evangelizar nesse lado da fronteira, após ter desenvolvido trabalho semelhante com os Curipaco na Colômbia. Entre os Baniwa a reação à atividade de Sophie foi espetacular, logrando conversões em massa e despertando novo surto messiânico. A missionária fazia uma pregação ativa contra os católicos e brancos em geral, condenando também as práticas xamânicas e outros rituais, além do uso do tabaco e do caxiri, que foram abandonados pela maioria.

Para Wright (1999b), a religiosidade tradicional se transfigurou na conversão religiosa, católica e evangélica, e na eclosão de movimentos milenaristas que mobilizaram a sociedade baniwa nos séculos XIX e XX. Atualmente a conversão religiosa permanece coexistindo, particularmente entre os católicos, com práticas xamânicas responsáveis pela manutenção da ordem cósmica. A conversão e seus desdobramentos até hoje repercutem no modo de vida baniwa, instaurando um conflito duradouro entre 'crentes' e católicos, restringindo particularmente entre os evangélicos - a reprodução das práticas xamânicas e de outras técnicas tradicionais de cura, e dos rituais pubertários masculinos. Tal contexto imprimiu acentuada transformação na vida social e moldou a configuração cultural hoje encontrada no mundo baniwa.

Dentre os especialistas de cura, Wright $(1996,1993,1999 a)$ assinala a existência de xamãs (malirı) propriamente ditos - que se hierarquizam segundo a profundidade de seus conhecimentos e a capacidade de viajar para níveis mais altos do cosmos - e os 'donos de cânticos', chamados em baniwa de malikai iminali, que associam um uso ritual do tabaco às recitações e cânticos denominados kalidzamai, executados nos rituais de passagem do nascimento e da puberdade. Essas práticas mantêm 
íntima vinculação com a produção mítica, com a categorização de doenças e com a manutenção da identidade e territorialidade dos grupos frátricos.

Internamente essa sociedade é dividida em aproximadamente cinco ou seis grupos de parentesco considerados consangüíneos entre si; tais grupos, denominados de fratrias, são, por sua vez, subdivididos em quatro a cinco $s i b s^{3}$ hierarquizados de acordo com a ordem mítica de nascimento na cachoeira de Hipana, o local de origem dos seres humanos. As fratrias recebem o nome de seu sib de maior importância ritual. Em território brasileiro existem atualmente três fratrias: Hohodene, Walipere dakenai e Dzawenai. Os membros de um grupo de consangüíneos partilham um forte senso de identidade e se constituem como o nível mais importante de tomada de decisão no plano da aldeia (Wright, 1992).

A relação entre as fratrias tem expressão política, pois é a vinculação a determinado grupo que possibilita a celebração de alianças matrimoniais, o controle de territórios no interior da terra baniwa e o conseqüente acesso aos recursos naturais necessários à sobrevivência cotidiana. Dentro do espaço de sua fratria, cada sib controla áreas específicas utilizadas para agricultura, caça, pesca e atividades rituais, estabelecendo uma conexão material e espiritual com a terra que habita e cultiva. Esta vinculação, explicada através da emergência mítica do espírito ancestral do sib em Hipana, propicia a definição de áreas diferenciadas para cada sib dentro do território frátrico, onde se localizariam também a morada dos mortos recentes e os lugares para onde os xamãs viajam por meio das canções dos rituais de cura e de liminaridade. Os territórios e as produções culturais a eles correlatas fornecem importantes elementos distintivos de identidade em relação aos outros grupos considerados não consangüíneos (Hill, 1986). Como os recursos naturais disponíveis nas diversas partes do território baniwa são desiguais, sua exploração favorece a manutenção de um sistema de relações de interdependência entre as fratrias.

As fratrias têm statusigualitário entre si; as principais formas de expressão da hierarquia ritual ocorrem nas relações inter e intra sibs, nas quais também se delineia a subordinação de gênero e de geração. Para Hill (1986), a hierarquia ritual entre os sibs atua como um meio de sustentação da ordem política, permitindo uma otimização do uso de recursos naturais que variam de acordo com as épocas do ano. Nos períodos de maior escassez de alimentos, ele identifica importante incremento nas interações intra sibs, ao passo que as relações interfrátricas, viabilizadas principalmente por meio das cerimônias de troca Pudali, seriam mais freqüentes nos períodos anuais de maior abundância de alimentos. Outrora, a hierarquização dos sibs, tal como em outras sociedades rionegrinas, se categorizava por meio de papéis rituais especializados de 'chefes', 'guerreiros', 'acendedores de cigarro', 'servos' etc.; parece ter havido uma superação histórica destas funções que não têm nos dias de hoje expressão concreta na vida cotidiana. 
A vinculação mítica das fratrias aos seus territórios tem expressão geopolítica; dessa forma, das três fratrias nomeadas que vivem no Brasil, duas Dzawenaie Walipere - habitam aldeias dispostas ao longo das margens do Rio Içana; a terceira, Hohodene, se distribui ao longo do Rio Aiari. O processo migratório produziu diversos assentamentos baniwa na calha do Rio Negro, na área urbana de São Gabriel da Cachoeira e no Médio Rio Negro, nos municípios de Santa Izabel e Barcelos, que não estão contemplados neste estudo. A geopolítica das relações frátricas é parte constitutiva de um grande conjunto de trocas materiais e simbólicas que estabelece um circuito infinito de obrigações mútuas entre consangüíneos e afins. ${ }^{4}$

Ao longo do texto, será utilizado o vocábulo Baniwa em alternância com as designações de fratrias e sibs quando isso se fizer necessário, enfatizando assim os manejos identitários utilizados pelos indígenas, que podem variar de acordo com as situações. Sendo inicialmente uma designação externa, o termo Baniwa foi incorporado e é usado taticamente como forma de auto-identificação em espaços e momentos de embates políticos que exigem uma aliança tática entre os diversos sibs; são situações em que as diferenças internas são colocadas entre parênteses na busca de unir forças, seja com a Foirn ou com as autoridades não-indígenas. Quando se trata de eventos locais realizados no âmbito das aldeias, o elemento predominante da auto-identificação é a filiação a um sib; neste contexto, o 'outro' é representado pelos afins pertencentes a outras fratrias.

\section{Contexto da pesquisa}

O trabalho vem sendo desenvolvido no município de São Gabriel da Cachoeira, Alto Rio Negro; essa região, conhecida na geopolítica brasileira como 'cabeça do cachorro', tem sido, nos últimos anos, palco de importantes embates entre grupos nacional-desenvolvimentistas, como os militares do Sivam/Calha Norte, e garimpeiros, entidades ambientalistas e de defesa da causa indígena, missões religiosas, sociedades indígenas e instituições transnacionais que conduzem a globalização das relações planetárias.

No campo específico da saúde, assinala-se a recente intervenção do Ministério da Saúde para a implantação dos Distritos Sanitários Especiais Indígenas (Dsei) ${ }^{5}$ uma tentativa de dar atenção à saúde de grupos etnicamente diferenciados e de resolver uma longa disputa com a Fenndação Nacional do Índio (Funai) pela condução dos rumos das políticas de atenção à saúde indígena. A movimentação em torno dos Dsei gerou, além de um incremento nas tensões e interações políticas, a celebração de relações conveniais entre um órgão de governo, a Fundação Nacional de Saúde, e entidades indígenas. Os convênios, celebrados não apenas no Alto Rio 
Negro, inauguram uma forma nova de legitimação das lutas etnopolíticas por setores do governo brasileiro, propiciando o repasse de recursos públicos para as Organizações Indígenas e gerando uma implícita aceitação/formalização do movimento indígena, cuja existência jurídica até poucos anos atrás era sumariamente contestada por órgãos como a Funai.

A parceria com políticas públicas, associada ao montante de recursos que vem sendo repassado para diversas associações indígenas na Amazônia, além de gerar impacto nas suas estratégias gerenciais e administrativas, também cria novos problemas de legitimidade e representatividade ante seus liderados, o que certamente influenciará os rumos futuros de sua atuação.

No cenário rionegrino entrecruzam-se diversos tipos de atores políticos indígenas: chefias de aldeia, catequistas, diáconos, pastores e padres indígenas, xamãs, benzedores, índios parlamentares, ocupantes de cargos do poder executivo municipal, agentes de saúde e membros de Organizações Indígenas. Boa parte deles participa ativamente dos conselhos de saúde, onde disputam sentidos no mercado simbólico local. Nestes fóruns seus discursos são continuamente atualizados pela presença do 'outro', ${ }^{6}$ expressando tanto as concepções e práticas sanitárias oriundas do contato interétnico quanto os saberes míticos, que ordenam não só a visão nativa de mundo, mas também as formas de apropriação e de uso político dos saberes advindos do mundo não-indígena. Deste conjunto de interlocutores, selecionamos os informantes da pesquisa, priorizando membros dos grupos Baniwa/Curipaco.

Os dados sobre doença, cura e cuidados foram obtidos a partir das informações de xamãs, donos de cânticos e outras pessoas que, não sendo especialistas de cura, foram apontados pelas Organizações Indígenas como conhecedores de doenças e plantas medicinais nativas. Boa parte deles exerce, ou já exerceu, funções de chefia de aldeia. Dados sobre biomedicina e organização de serviços da rede de saúde foram coletados junto a estes mesmos informantes e mais os capitães e vice-capitães e agentes de saúde baniwa/curipaco.

O campo específico da saúde propiciou a exploração da interface entre reprodução e transformação das formas próprias de organização social e política do grupo e as atividades desenvolvidas com as instituições da sociedade nacional brasileira, com o objetivo de garantir o direito à diferença cultural, o acesso aos direitos universais de cidadania e aos benefícios gerados por políticas públicas, entre as quais se destaca a de saúde. Tais relações, ainda que travadas no âmbito das instituições e fóruns decisórios não-indígenas, são fundadas no princípio de uma etnicidade singular, sendo matizadas pelo modo indígena de vida, que orienta as representações e práticas sociais dessas lideranças, quer no campo da saúde (nosso foco de interesse), quer nas outras ações realizadas no âmbito mais geral do movimento indígena. 
Embora a organização política baniwa/curipaco se constitua um dos principais eixos da investigação, também foram coletadas informações entre lideranças indígenas de outros povos rionegrinos. Isso se fez necessário (e possível) porque, apesar da coexistência de distintas visões ontocosmológicas, a realidade rionegrina gera também um conjunto de padrões culturais comuns, de interligações políticas, sociais, religiosas e de trocas comerciais que faz com que, em muitos aspectos, estas sociedades operem como uma totalidade cultural, na qual as relações intertribais se influenciam e se condicionam mutuamente.

Partindo deste princípio, formulamos a hipótese de que os dados coletados entre os Baniwa poderiam ser analisados também à luz da dinâmica das entidades políticas de outros povos da região e vice-versa, configurando um processo de mútua retroalimentação. Refletir sobre as práticas políticas dos baniwa, desconsiderando sua íntima interação com o restante do movimento indígena rionegrino, coordenado pela Foirn - com quem as lideranças baniwa e curipaco mantêm um contato estreito e cotidiano e onde buscam referências e apoio político, financeiro e gerencial para desenvolver atividades em suas regiões de origem - empobreceria a análise. Em função disso, procuramos construir a investigação da política interna do mundo baniwa/curipaco, mas sempre de forma articulada com interações estabelecidas com líderes e organizações de outras sub-regiões do Alto Rio Negro.

As informações foram coletadas em quatro regiões geopolíticas distintas dentro da área baniwa: no Médio Içana, entre os sibs Kadapolitana, Dzawenai, Walipere Dakenai; Alto Içana, com informantes dos sibs de falar Curipaco Comada minanai e Capithi minanai; Rio Aiari, onde trabalhamos com informantes Hohodene, Walipere Dakenai e Mawlieni, além de dois membros da etnia Cubeo que ali vivem. A quarta região geopolítica é São Gabriel da Cachoeira, onde foram colhidas informações sobre o movimento indígena pan-rionegrino.

A análise congregou questões referentes à organização social dos povos rionegrinos, ao contato interétnico, às representações sociais e práticas organizadas em torno da saúde, da doença e de cuidados, à circulação de informações sobre saúde, à produção de discursos e práticas políticas e técnicas em saúde, ao exercício do poder político indígena que vem sendo ressignificado pelas relações interétnicas, e particularmente pelas práticas do movimento indígena que, além de propiciar a (re)construção da identidade indígena na militância étnico-política, também viabilizam a intervenção dos grupos indígenas nas políticas públicas. A proposta aqui formulada busca, a partir de um enfoque nas relações de poder, tratar essas questões como uma totalidade capaz de respeitar a indissociabilidade da realidade abordada na pesquisa. 
1 Os povos de língua Maku costumam viver em terra firme, distante dos grandes cursos d'água, mas como estabelecem interações rotineiras com os grupos Tukano, podem ser agrupados nesta sub-região geográfica.

2 O termo Baniwa não é uma auto-identificação, tendo sido produto do processo colonizatório; entretanto ele foi incorporado pelos membros dessa etnia, sendo utilizado regularmente nos circuitos de relação interétnica. Na literatura etnológica o grupo tem também outras denominações, sendo chamado de Wakuenai, na Venezuela, e de Curipaco, na Colômbia (Wright, 1992).

3 Os sibs são grupos de parentes consangüíneos, descendentes de um mesmo ancestral mítico do sexo masculino. Um conjunto de sibs forma uma fratria; eles são hierarquicamente ordenados de acordo com a seqüência de saída da cachoeira de Hipana, do ancestral que originou o grupo familiar. Segundo as regras da sociedade baniwa, os membros de uma fratria devem procurar casamento entre pessoas pertencentes a outra fratria, distinta da sua, sob pena de cometerem incesto. A inclusão de novos membros na sociedade é dependente da origem do pai do recémnascido, visto que esse pertencerá ao sib paterno, num sistema denominado de patrilinear, (Journet, 1980). Como se verá posteriormente, a relação entre os sibs e as fratrias também é essencial para o entendimento da expressão da doença nesse grupo étnico.

4 O termo 'afinidade' será utilizado para designar trocas matrimoniais, reais ou potenciais, entre membros de fratrias diferentes. Por sua vez a palavra 'afim' será utilizada para designar cunhados reais ou potenciais, ou seja, não consangüíneos.

5 Distritos Sanitários Especiais Indígenas são formas de organização de microssistemas de saúde de base local dirigidos especificamente à prestação de cuidados de saúde para a população indígena residente em sua área de abrangência, constituindo-se um subsistema dentro do Sistema Único de Saúde.

6 O 'outro' não apenas como o branco, o não-índio, mas abrange também representantes de grupos étnicos que mantêm relações ancestrais de disputas e rivalidades atualizadas num contexto moderno, que pode exigir que inimigos tradicionais acirrem suas disputas ou que estabeleçam alianças políticas conjunturais num conselho de saúde. 

Mitologia, Política, Gênero e Geração 



\section{Os Sentidos Cósmicos e Políticos da Produção \\ e Reprodução da Doença}

Este capítulo trata das representações e práticas organizadas em torno da produção social de doença e de cuidados que visam à prevenção e cura do evento patológico. Na língua baniwa os termos usados para designar genericamente os eventos patológicos são basicamente dois: Idzamikatti, que indica doenças graves, que podem levar à morte, e Ipoate, utilizado para se referir a uma doença de pouca gravidade, ou manifestações iniciais em que predominam sintomas vagos como febre, dor e mal-estar geral, que podem se curar sozinhos; obviamente, todo quadro de Ipoate é passível de evoluir para uma situação de Idazmikatti.

Em termos antropológicos a idéia baniwa de doença recobre o que foi distinguido por Young (1985) como sickness, ou seja, uma alteração no comportamento considerado socialmente aceitável, gerando uma perturbação na harmonia dos relacionamentos sociais, comprometendo sua capacidade potencial de cumprimento das obrigações cotidianas; recobre também o conceito de illness, ou seja, gera um conjunto de interpretações sobre as razões pelas quais o evento patológico ocorreu e como ele se deu, o que no caso baniwa remete à sua produção mítica. A noção de illness subentende a existência de um "papel social de doente", uma alteração no exercício de seus direitos e deveres no âmbito comunal e comprometimento da plena condição humana (Buchillet, 1991c, 1991d).

Não existe uma palavra específica em baniwa para designar o conjunto de cuidados destinados a preservar e recuperar a saúde; tampouco existe a noção de 'tratamento', concebido como técnica de recuperação física do corpo. Os xamãs utilizam o termo pamatchiatsa para designar uma idéia bem mais ampla, de melhoria geral da qualidade de vida de uma pessoa. Para eles o cuidado com o corpo é indissolúvel do cuidar da alma, da natureza e da harmonia nas relações sociais.

O termo 'cuidados' está sendo usado aqui no sentido de um conjunto de valores expressos em atos e palavras, que objetivam auxiliar pessoas que, fragilizadas em seu corpo e/ou espírito, enfrentam dificuldade - permanente ou temporária - em desempenhar os papéis cotidianos considerados adequados ao seu status no seio da coletividade (Saillant, 1999:5). A noção cuidados está ligada à dimensão relacional da vida, compreendendo processos de aprendizagem, de 
demarcação de identidade dos grupos que os praticam e reconhecimento da alteridade naqueles que não partilham as produções culturais dos produtores de cuidados, sendo por isso considerados 'errados' e demandando normalização.

Em seu estudo sobre os Achuar, Philippe Descola (1989) observa que as representações que os membros desta sociedade elaboram sobre a natureza equivalem à idéia que eles têm de si próprios como grupo social. Desta forma, os Achuar atribuem aos seres da natureza comportamentos análogos aos preconizados pelo modelo indígena de vida social, reconhecendo na natureza os mesmos eventos - troca de mulheres e outras formas de reciprocidade, disputas, conflitos, seduções, alianças e guerras - que povoam sua vida cotidiana. Segundo Descola, essa forma indígena de interagir com o meio natural desconhece a dicotomia entre natureza e cultura estabelecida pela razão ocidental, que representa a primeira como algo restrito ao plano puramente material da vida e exterior à sociedade humana. Para o pensamento Achuar, os seres da natureza possuem atributos típicos da humanidade e as regras que regem seu comportamento são similares às daquela.

Viveiros de Castro (1996) retoma esta discussão num plano mais genérico, situando tais características como comuns a diversos povos indígenas sul-americanos, para os quais o mundo estaria povoado por pessoas que podem ser humanas e não-humanas e que desenvolvem interações entre si, apesar de representarem o mundo através de opostos simétricos que levariam, por exemplo, os animaisespíritos a considerar a carne e o sangue humanos como alimento, de modo análogo, mas em sentido inverso às representações dos humanos sobre suas fontes animais de comida. No contexto destas relações, os xamãs ocupariam uma posição diferenciada, por transitarem entre o ponto de vista humano e o dos seres da natureza, ocupando posições simultâneas num e noutro espaço social.

Prosseguindo a análise dessas características das culturas ameríndias, o autor demonstra que a intencionalidade de atos e propósitos seria comum a todos os seres, evidenciando um tipo de subjetividade não-humana, mas semelhante à consciência humana; a distinção aparente entre humanos e não-humanos dar-se-ia apenas na forma/envelope corporal assumida por eles, mas sem que os seres da natureza deixem de manter "uma relação privilegiada com outras figuras prototípicas da.alteridade, como os afins" (Viveiros de Castro, 1996:120). Nesta perspectiva, haveria uma "socialidade englobante", da qual a natureza é parte de uma sociedade cósmica onde coexistem humanos, plantas e animais (Viveiros de Castro, 1996:121).

Viveiros de Castro alerta que a questão é ainda mais complexa, pois não se trata apenas de uma projeção metafórica da espécie humana sobre os não-humanos; tratar-se-ia, na verdade, de uma inversão de perspectiva: a cosmologia ocidental postularia uma "continuidade física e uma descontinuidade metafísica (...) entre humanos e os animais", ao passo que as culturas indígenas postulam uma... 
continuidade metafísica e uma descontinuidade física entre os seres do cosmos. Para os ameríndios, a condição humana seria a 'forma geral do Sujeito'; humanos e não-humanos partilhariam a mesma essência, mas difeririam no modo de perceber e atuar sobre o mundo, em função da especificidade de seus corpos ${ }^{7}$ (Viveiros de Castro, 1996:129)

Os valores, as formas de organização da vida social, seriam análogos - isto é, haveria uma continuidade nas propriedades do espírito que servem de eixo para a organização da representação do mundo -, mas a especificidade dos corpos exige que cada um deles apele para formas distintas de intervenção sobre a realidade.

Embora longa, a discussão é relevante para o entendimento da expressão das doenças cuja origem é atribuída, pelos Baniwa, às relações com a alteridade. Do ponto de vista de um membro de fratria, esta categoria compreende todos os que não pertençam ao seu grupo de agnatos, incluindo-se aí os não-humanos que povoam seu cosmos; estes são considerados 'pessoas', na medida em que, tal como os humanos, ocupam espaço na estrutura social, produzem ações deliberadas, nãoaleatórias e têm capacidade de julgamento fundada em padrões morais partilhados por sua sociedade e pela dos Baniwa. Tais noções implicam a existência de seres humanos considerados como 'não-pessoas', caso se mostrem incapazes de atender às qualificações implícitas na concepção de pessoa.

Overing (1983-1984) tem analisado o que ela chama de uma "filosofia da existência" comum a diversos grupos ameríndios, entre os quais os povos do noroeste amazônico; tal 'filosofia' expressa as formas de entendimento desses grupos na relação com a alteridade, identificada como uma 'diferença' associada ao perigo e à violência, mas também à reafirmação da identidade e à geração de variações positivas e renovadoras do conjunto de forças e poderes da cultura local. A autora afirma que a forma encontrada pelos grupos para limitar a periculosidade do 'diferente' é o estabelecimento de relações de reciprocidade que fundam a vida social, propiciam a renovação e a perpetuação da identidade, que é simultaneamente ameaçada e garantida pela existência da diferença. Identidade implica segurança, mas também a negação da vida social, que só se faz possível pela interação com a alteridade.

Analisando a estrutura das recitações e cânticos kalidzamai, Wright (1993) demonstra que eles contêm uma taxonomia dos seres que povoam o universo baniwa, contemplando os seres-espíritos de animais aquáticos e terrestres, os ancestrais frátricos e os espíritos dos mortos que, juntamente com os brancos e outros povos nativos, constituem a alteridade baniwa que se configura como um espaço heterogêneo que se desdobra em planos diferenciados.

Se tomarmos como exemplo as representações de um membro do sib walipere dakenai, podemos conceber o mundo como um conjunto de círculos concêntricos, que comportam, no entanto, uma divisão primordial entre o 'nós' 
(os consangüíneos) e os 'outros', todos os não-parentes; esta última categoria, por sua vez, é subdividida em um plano mais próximo do 'nós', ocupado pelos membros de outras fratrias, afins reais com quem as trocas rituais e matrimoniais costumam ser concretizadas. A eles segue-se o círculo onde se dispõem outros povos indígenas rionegrinos e finalmente o plano mais externo, onde se situam os seres da natureza, uma categoria que comporta também os brancos que se identificam com seresespíritos canibais do panteão baniwa.

Estas idéias são congruentes com as dos informantes de Wright, que em seu texto Prophetic Traditions Among the Baniwa (no prelo) formulou um modelo concêntrico de organização do espaço social baniwa, o qual reproduzimos de forma ligeiramente modificada:

Figura 1 - Espaço social baniwa

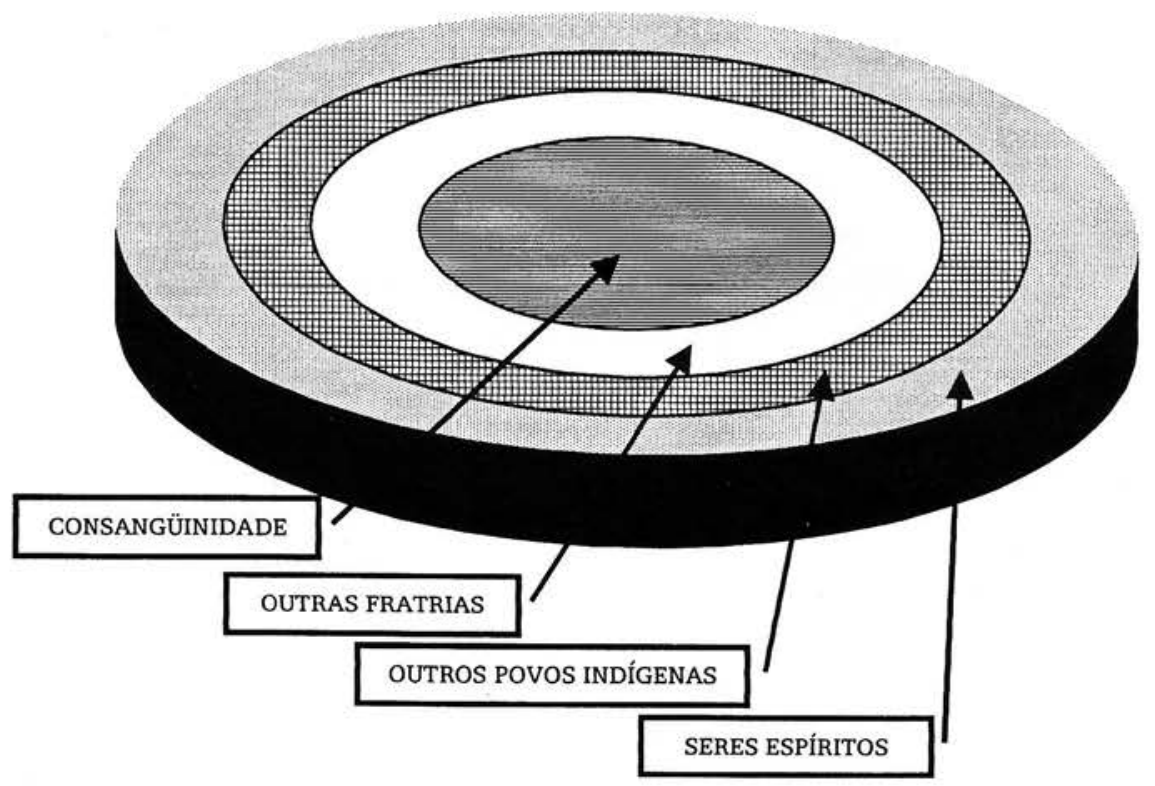

Fonte: Adaptado de Wright (no prelo)

Numa cosmovisão como essa, quanto maior a distância do espaço central, menores as expectativas de reciprocidade positiva que só se realizam plenamente no plano da consangüinidade; a alteridade é o lugar da reciprocidade negativa onde imperam perigo, guerra, violência e vingança. Tal modelo será retomado posteriormente, na análise da reprodução do evento patológico, cuja origem é atribuída prioritariamente à alteridade. 
A partir dessas premissas os circuitos de produção e modulação da saúde, da doença e dos cuidados podem ser entendidos como formas de expressão das relações contratuais estabelecidas entre conjuntos de pessoas, humanas e nãohumanas, que formam o universo baniwa. As interações sociais travadas entre esses grupos organizados em classes de idade, gêneros, sibs e fratrias, pertencem ao espaço do 'político', aqui caracterizado como lugar de relações assimétricas de competição e de cooperação travadas entre grupos que, para obter os fins desejados, desenvolvem entre si estratégias de manipulação, de convencimento, de contestação e de alianças. Trata-se, portanto, de relações de poder e de suas formas de exercício numa dada sociedade.

Para Santos-Granero (1990), nas sociedades indígenas amazônicas, o poder político se fundamenta na posse de conhecimentos rituais que propiciam capacidade de intervenção nos processos produtivos e reprodutivos. Tais "ritos de produção" conferem autoridade política a seus detentores, pois se caracterizam como fatores essenciais para fomentar a fertilidade, os nascimentos, a prosperidade, a harmonia e o bem-estar; enfim, todos os elementos necessários para promover a manutenção da vida social. O monopólio destes saberes propicia o controle sobre os principais meios de produção nestas sociedades, ou seja, as pessoas (1990:30).

Em acordo com esta linha de pensamento, caracterizamos os saberes sobre doença, cura e cuidados de saúde como "meios místicos de produção" que propiciam o controle de frações da sociedade baniwa sobre as outras que estão desprovidas dos conhecimentos rituais indispensáveis para garantir a continuidade da vida, legitimar a ordem social vigente e aplicar sanções morais aos que rompam com as prescrições neles contidas (Santos-Granero, 1990).

Nesta sociedade, como em tantas outras, existe uma distribuição desigual de saberes entre os elementos formadores de sua estrutura social. As relações entre fratrias são relativamente igualitárias, mas a hierarquização entre sibs, homens e mulheres, jovens e velhos gera uma distribuição desigual dos conhecimentos que propiciam o controle dos meios místicos de preservação da saúde. Dentre as diversas possibilidades de exercício de poder na sociedade baniwa, optamos por analisar, neste capítulo, aquela que incide sobre as relações de gênero, citando de passagem o controle de geração e as hierarquias que regulam as relações entre os sibs, aspectos que serão aprofundados nos capítulos seguintes.

A análise das representações e práticas sobre doença, cura e cuidados veiculará o entendimento de como se processa não apenas o controle sobre estes meios humanos de produção, mas também como este se naturaliza, se legitima e como opera em íntima relação com as atividades religiosas, interações familiares, regras de casamento, de residência etc. Tais atividades são atribuições do parentesco e atuam como executores das sanções morais e espirituais que mantêm a ordem social. 
Entre os Baniwa, a longa história de contato não retirou a regulação dos conflitos e das contradições sociais do campo do parentesco. Seus membros continuam desenvolvendo estratégias fundadas no saber mítico-religioso - entre as quais se destacam aquelas ligadas à doença e à cura - com as quais almejam fortalecer o controle sociopolítico da sociedade pelas gerações mais velhas, cuja hegemonia é continuamente ameaçada pela presença de outras formas de poder engendradas no contato interétnico. No âmbito da consangüinidade, este poder incide sobre os membros mais jovens ${ }^{8}$ do grupo; no plano da afinidade, expressa-se nas relações entre fratrias, envolvendo principalmente as mulheres que circulam entre elas através das trocas matrimoniais.

As categorias de doença aqui estudadas são o que Sindzingre (1981) denomina de categorias a priori, isto é, um conjunto de informações prédisponibilizadas para os membros de uma sociedade, que lhes permite elaborar interpretações sobre o evento patológico e utilizá-las como um meio preditivo e orientador da ação. Tais categorias não são de fato apriorísticas, mas como se geram em ciclos de ação social produzidos no passado, as gerações mais jovens convivem com elas desde seu processo de socialização primária, tendendo a interpretá-las como tal. A internalização das categorias de doenças faz parte de processos mais amplos de incorporação da linguagem e dos sistemas de significados e valores vigentes na cultura do grupo, o conjunto todo opera como forma de reprodução da visão de mundo das gerações antecedentes (Hill, 1988).

Copans (1971:111) considera que quando o parentesco forma a armadura de uma sociedade, ele também fornece modelo à linguagem e à política, definindo as formas como se dá a coesão social e como os poderes são repartidos entre os diferentes grupos na sociedade. Tais premissas serão aplicadas ao longo do texto, onde tentaremos demonstrar que as estratégias de alianças e confrontos políticos estabelecidos no âmbito do parentesco orientam as formas de expressão da doença e de aquisição e gerenciamento de saberes e poderes que vão sendo engendrados ao longo da história do grupo e são incorporados ao conjunto de cuidados de saúde disponíveis na sociedade.

Os sentidos atribuídos aos episódios de doença remetem, por um lado, à cosmovisão do grupo, aos valores e às regras de conduta (ou à transgressão deles) daí decorrentes e, por outro, às práticas sociais nas quais as explicações causais de doença serão reinterpretadas de acordo com a possibilidade de apropriação, pelo sujeito, do conjunto de informações pré-disponibilizadas sobre doença e cura. Tais estratégias propiciam a formação de um 'campo de poder', aqui entendido como um conjunto de relações de força que grupos, no interior de sociedades determinadas, estabelecem entre si. Por meio do manejo dessas relações, cada um deles tem como objetivo garantir um quantum de força social suficiente para fazer valer o reconhecimento de suas posições como sendo mais legítimas que a de seus 
oponentes (Bourdieu, 1989); representações de doença e cura são elementos constitutivos do quantum de força acumulado pelos grupos e utilizado para consolidar suas posições na sociedade.

No caso baniwa, os relatos míticos constituem o eixo essencial para o entendimento da origem e manutenção da doença neste mundo. Os mitos que tratam da origem e reprodução da sociedade contêm adendos ou pequenas variantes explicativas dos eventos de doença e cura. Sendo formas de poder político, os sentidos sobre a doença têm um indissolúvel componente moral, o que lhes permite gerar formas de coação sobre os membros do grupo. As narrativas míticas situam, por um lado, a causalidade da doença como um tipo particular de pensamento religioso, que demanda procedimentos rituais específicos para viabilizar uma interação com divindades capazes de proceder à recuperação do bem-estar e da saúde; por outro lado, produzem uma interface da doença com os eventos da vida cotidiana, proporcionando parâmetros de orientação para a ação ante os mesmos. Elas atuam como sistemas de percepção e de pensamento, fornecendo ainda um conjunto de taxonomias de objetos e espécies naturais que se expressam nos kalidzamai e nas formas de classificar os tipos de doença (Hill, 1989).

A análise da produção e reprodução da doença exige uma explicação prévia da cosmogonia, que lhe confere inteligibilidade. Existem várias publicações de Wright (1996) (1993/1994, 1998) e de Johnatan Hill (1989) tratando desse tema. A partir delas faremos um resumo dos aspectos da cosmogonia que têm relevância para a discussão subseqüente sobre doença e cura.

\section{Cosmogonia, violência, doença e morte}

O mundo primordial, temporal e espacialmente indiferenciado, conquista a diferenciação através das ações dos seres miraculosos que o povoam e que se sucedem ao longo de um tempo espiralado que se perpetua no mundo de hoje; o plano vertical garante a continuidade entre as gerações, entre o céu e a terra, entre o mundo ancestral e o atual. A guerra permanente, o caos e o não-cumprimento de regras de convívio social que imperavam no começo dos tempos e que inviabilizam o estabelecimento de uma ordem social são apenas parcialmente controladas pelos seres que antecedem a humanidade. Seus componentes disruptivos permanecem latentes e são responsáveis pelo aparecimento da doença e da desordem que enfeiam e maculam o mundo atual (Wright, 1996).

O início do cosmos baniwa é uma sucessão de sangrentas lutas entre os proto-humanos e seres-espíritos não-humanos pelo controle do mundo. Toda esta atividade é centralizada numa família de supra-humanos formada por Nhiãpirikoli, seus irmãos Dzooli, Eeri e Mawirikoli, o irmão mais jovem, que foi também a 
primeira pessoa a morrer. Outros personagens importantes são Kowai, filho de Nhiãpirikoli e Amaro, a primeira mulher. Essa família é obrigada a travar guerras constantes com grupos inimigos, como a família das serpentes-peixe, chefiadas por Omáwali e a tribo dos trovões que também aparecem nos relatos, na forma dos macacos Eenonai, os donos primordiais do veneno. Os inimigos com quem Nhiãpirikoli guerreava eram de fato seus afins, sendo comuns os relatos das escaramuças contra seus sogros e cunhados.

Nhiãpirikoli e seus irmãos são órfãos, porque seus pais foram predados por animais canibais ancestrais nas incessantes guerras de todos contra todos do caos primordial. Eles crescem sob o signo da vingança a ser feita contra os assassinos de seus pais. A Likoada, regra baniwa que regula a vingança, a retribuição de agressões e todas as formas de troca, é um dos elementos essenciais no circuito de violência que se perpetua no seio de um mundo caótico, onde predominam situações de violência extrema que ameaçam a permanência da humanidade no mundo. A Likoada será, como veremos, uma das causas mais importantes da perpetuação de doenças no mundo.

Wright (1993/1994) descreve a organização do cosmos baniwa em três ciclos: o primeiro se refere a este período de grande turbulência e guerra contínua entre Nhiãpirikoli e os animais/espíritos canibais; é o momento em que a divindade se esforça por acumular poder mágico (Malikaı) e assegurar o domínio da ordem humana sobre o caos e da vida sobre a morte, tornando o mundo seguro para as futuras gerações. Os mitos deste ciclo mostram todo tipo de comportamento excessivo, tais como canibalismo, incesto, agressividade e sexualidade incontroladas e uso desenfreado de veneno nas guerras de Nhiãpirikoli e seus consangüíneos com os serpentes-peixe, macacos/trovões e outros seres. Os esforços do herói para superar este estado de coisas são recompensados apenas em parte; o caos primordial sempre reaparece nos ciclos posteriores, reproduzindo-se até o mundo atual. A vida dos homens, e particularmente, dos xamãs, é uma luta constante para manter as manifestações do caos sob controle e possibilitar a continuidade do cosmos. Diversas doenças que acometem hoje os Baniwa têm origem nas guerras do primeiro ciclo cósmico.

A irreversibilidade da morte é um dos eventos contidos neste primeiro ciclo. No mito que trata do tema, Mawirikoli, o irmão mais jovem de Nhiãpirikoli é envenenado pelos Eenunai, recebendo um tratamento que promove uma progressiva reaproximação com a condição humana, expressa na melhoria dos sintomas; o processo de purificação é interrompido antes do completo restabelecimento do doente, pois este é seduzido por uma mulher com quem mantém relações sexuais, proibidas em seu estado de reclusão. A transgressão torna sua morte irreversível, condição que se estende à humanidade futura. 
A narrativa ressalta dois pilares na produção de sentidos sobre a doença e a ordem social baniwa: a desobediência e impulsividade dos jovens e a sexualidade desenfreada das mulheres. Os cuidados pela manutenção da saúde e bem-estar visam sobretudo ao controle das ações destes seres, cuja menor habilidade no cumprimento de seus deveres para com o corpo social os coloca na posição de pessoas incompletas, com dificuldades em produzir juízos morais adequados e em cumprir as normas sociais, ameaçando tornar vãos os esforços dos homens mais velhos no trabalho de contínua restauração da ordem cósmica e social.

Ainda segundo Wright (1993/1994), o segundo ciclo cósmico se caracteriza como um período de transição entre o primeiro e o mundo atual. Nesse ciclo o herói cria condições para a reprodução da ordem social; aqui se completa a diferenciação entre homens e mulheres, nasce Kowai, filho de Nhiãpirikolie Amaro, que institui os rituais de pós-nascimento e de iniciação pubertária.

Kowai é o personagem principal desse ciclo mítico, que se encerra quando seu pai o atira numa fogueira, matando-o. As características físicas deste personagem são muito importantes para o entendimento da expressão da doença e de formas de curar. O corpo de Kowai é uma síntese de tudo o que existe, exceto o fogo; através da música de seu corpo, ele cria toda espécie de seres vivos e expande o mundo; também estabelece, através dos ritos de iniciação masculina, as regras de comportamento que devem orientar a socialização das gerações humanas futuras. A dificuldade de controlar o comportamento inadequado dos jovens aparece como um elemento marcante no segundo ciclo; é o comportamento irrefreado dos iniciandos, incapazes de controlar seu apetite e manter o jejum deles exigido, que desencadeia sua morte e o subseqüente assassinato de Kowai.

A relação entre Kowai e Nhiãpirikoli remonta a um conjunto de agressões e vinganças recíprocas, trazendo a violência para o plano da interação entre consangüíneos, resultando igualmente em canibalismo, assassinato, envenenamento e vinganças, práticas que até então caracterizavam o conflito entre afins.

$\mathrm{O}$ terceiro ciclo é um momento de conquistas culturais para a humanidade; aqui surge a noite, efetua-se a domesticação do fogo e das plantas selvagens, a criação das plantas medicinais e dos cânticos terapêuticos por Dzooli. O período é marcado ainda pela diferenciação e distribuição desses elementos de cultura entre os distintos povos que compõem as sociedades indígenas rionegrinas. Ele enfatiza também outra faceta dos conflitos e disputas que perpassam a sociedade baniwa: as guerras travadas entre os gêneros, que eclodem de forma aguda após a morte de Kowai, devido ao roubo das flautas sagradas pelas mulheres; estas fogem para fora da terra baniwa com o produto de seu roubo e tocando-as voltam a expandir o mundo que havia encolhido após a morte de Kowai. O roubo desencadeia uma guerra entre Nhiäpirikoli e as mulheres, resultando na expulsão delas do território ancestral baniwa. O final desse ciclo é demarcado pelo afastamento de Nhiãpirikoli da humanidade. 
Em cada ciclo observam-se nichos diferentes de eclosão da violência, um elemento constante na interação entre os personagens míticos. No primeiro ciclo, ela se configura principalmente como guerra entre humanos e animais-espíritos afins; no segundo ela eclode nas relações agressivas entre consangüíneos, com ênfase nas tensões entre Kowai e seus irmãos canibalizados, Kowaie Nhiãpirikoli, Kowai e seus tios, ou seja, entre gerações mais velhas e mais jovens. No último ciclo, o eixo da violência incide nas relações de gênero; se em momentos anteriores a agressividade entre homens e mulheres se apresentava de forma latente, aqui ela explode em toda plenitude, gerando conseqüências permanentes para a configuração da futura ordem humana.

Outra expressão recorrente de violência nas diferentes fases dos ciclos cósmicos é a irrupção de grandes incêndios, que devastam a terra e matam personagens-chave. $\mathrm{O}$ calor é ligado ao ardor e à dor da picada das serpentes e da penetração de flechas mágicas como as usadas por Nhiãpirikoli para matar a serpente Omáwali; ele também simboliza Amaro, cuja genitália é quente e perigosa, pois sua vagina foi originada de um tiro desferido por Nhiãpirikoli para que Kowai nascesse. $\mathrm{O}$ calor de Amaro é associado às armas, ferramentas, febres e às doenças trazidas pelo branco. A genitália feminina é também associada ao adultério ancestral conectando calor genital com a sexualidade inadequada e a conseqüente geração de doença.

Entretanto o calor se opõe a Kowai, 'dono' dos venenos, cujo corpo é a base de formação de todos os elementos do mundo. Sendo um corpo cheio de veneno, o mundo inteiro se torna venenoso, e o fogo se torna um elemento de purificação de Kowai/mundo, atualizando-se no calor das chicotadas e das plantas urticantes usadas nos rituais pubertários e na pimenta das refeições cotidianas. No cosmos baniwa a ação do fogo simboliza a transição entre os ciclos, a purificação ritual, a superação de fases e a recriação (violenta) de novas formas de existência.

Outros elementos importantes para o desenvolvimento dessa temática são:

- Os cânticos, que os informantes chamam de rezas malikai e kalidzamai, recitados em situações de liminaridade e doença, fornecem outras indicações essenciais para o entendimento da lógica das concepções baniwa sobre doença e cura. $\mathrm{O}$ térmo Malikaié utilizado para designar este tipo de cântico, mas também expressa uma complexa categoria de poder simbólico: é o poder mágico utilizado por Nhiâpirikoli para lutar contra os animais-espíritos e impor uma ordem humana ao cosmos. No mundo atual ele expressa a capacidade xamânica de reordenar o cosmos, curar doentes, limpar o mundo do mal e da sujeira, que, para os Baniwa, estão intimamente ligados; entretanto, Malikai também comporta o poder de gerar maldade, destruição, doença e desavenças entre as pessoas. Enfim, é um termo ambíguo, que expressa a capacidade de mudar magicamente a ordem das 
coisas, com todas as conseqüências construtivas e destrutivas geradas pela utilização de um poder desta natureza.

Nos relatos míticos a busca de poder mágico envolve sangrentas lutas dos ancestrais entre si e com os animais-espíritos; essas lutas e suas conseqüências se atualizam hoje nos episódios de doença, nas guerras mágicas travadas entre os xamãs e nas viagens que eles fazem ao céu para finalidades diversas, entre as quais a busca de cura para os doentes. Os xamãs dão continuidade às lutas de Nhiâpirikoli, atuando como elementos-chave para manter o equilíbrio de um mundo permanentemente ameaçado pela maldade, a doença, a sujeira e infortúnios diversos (Wright, 1996).

- A busca de saber/poder pode ser uma importante fonte de doença, infortúnio e morte, caso o aprendiz não consiga usar seus saberes de forma socialmente responsável e sua aquisição se destine à mera obtenção de benefícios pessoais. O poder é obtido sobretudo na alteridade, mas o risco que sua obtenção acarreta exige salvaguardas que limitem suas potencialidades destrutivas e viabilizem sua apropriação pelos membros do grupo.

Santos-Granero (1994) fala nas conseqüências, em sociedades indígenas, da aquisição de poder e nas obrigações que incidem sobre quem o obteve. Segundo o autor, nesses grupos é corrente a associação entre a busca de conhecimento sagrado e o uso moral do mesmo, revertido em benefício comunal. Entre os Baniwa, a associação entre aquisição de saber/poder (malikal) e seu uso moral é reiterada nos mitos - que também enfatizam as catástrofes e doenças decorrentes do mau uso do malikai - e representa um ponto-chave na manutenção da vida social e na reprodução da ordem para as gerações futuras. Tais eventos ancestrais são evocados para justificar a não-extensão deste conhecimento às mulheres e aos não iniciados, cuja condição poderia gerar um uso irresponsável dos mesmos. Esta limitação indica a existência de um poder simbólico que opera através de redes de relações sociais e é desigualmente distribuído entre os membros da sociedade. Existe uma hierarquia na distribuição dos saberes, e aqueles que detêm menor quantum de poder simbólico sofrem uma restrição de acesso aos outros espaços de poder da sociedade.

Para Hill (1989) e Wright (1993/1994, 1996), entre os Baniwa as gerações se sucedem numa verticalidade contínua e sua sucessão representa o elo entre o passado mítico, de onde tudo surge, e o futuro, representado pelas gerações que virão. A continuidade é garantida pelo respeito e reprodução criativa dos pilares que ordenam a sociedade; a manutenção do eixo vertical do cosmos se deve à capacidade de seguir os preceitos estabelecidos pelos pais, avós e gerações de ancestrais; aqui, a possibilidade de adoecimento se deve essencialmente à transgressão (deliberada ou não) das regras de comportamento socialmente 
aceitáveis que as gerações mais velhas impõem às mais novas através de uma série de artifícios de cultura (rituais de passagem, regras de purificação, regras de captura, preparo e consumo de alimentos, regras de casamento etc.). Doença, cura e cuidados fazem parte de um complexo conjunto de estratégias que tem como objetivo garantir a reprodução física e simbólica da sociedade e a congruência entre o comportamento de seus membros e os padrões morais vigentes.

- A condição feminina é outro elemento importante na gênese e reprodução da doença e infortúnio. Numa advertência formulada para os povos tukano, mas perfeitamente aplicável a este contexto, Jackson (1992) lembra que as representações sobre a feminilidade escondem dimensões mais amplas da vida social, tais como a diferenciação/indiferenciação entre homens e animais e homens e mulheres, a heterossexualidade e as relações entre agnatos e afins; elas propiciam o desenvolvimento da consciência da diferença entre o 'nós' e o 'outro', estabelecido nas relações horizontais de troca com a alteridade, nas quais as mulheres constituem o principal objeto.

Também entre os Baniwa, os estudos de Hill $(1993,1987)$ sobre os rituais Pudali mostram que, além de viabilizar as trocas matrimoniais, eles expressam uma íntima interação entre assimetria de gênero e a diferenciação entre humanos e animais, produzida ao longo de uma trajetória que vem dos tempos míticos até a realidade atual. Os rituais Pudali não são apenas sessões de trocas entre afins, sendo também um ativo mecanismo simbólico de abolição temporária das diferenças, de transformação do 'outro' em um 'semelhante a mim', limitando a periculosidade da relação entre doadores e receptores de esposas e potencializa a constituição de alianças seguras com uma alteridade perigosa. O Pudali expressa a multifuncionalidade das relações de troca de mulheres, que engloba aspectos econômicos, políticos, relações morais, de comunicação, de saberes sobre a vida animal, enfim campos diversos em interação, que numa ótica não-indígena constituiriam espaços sociais diferenciados, mas que aqui se apresentam como funções sociais 'totais', que visam conservar a ordem social vigente.

Os trabalhos de Jackson (1988, 1992) e de Chernella (1997, 1988a, 1988b) que abordam a questão de gênero foram produzidos a partir de material coletado entre os grupos Tukano; como não existem informações sistemáticas sobre esta temática para os Baniwa, utilizaremos tais produções como ponto de apoio para a discussão do tema, lançando mão também do já citado texto de Hill (1987), que se refere, de passagem, às relações entre homens e mulheres no mundo baniwa.

Para Jackson (1992), a presunção dos Tukano de que os homens seriam superiores às mulheres, justificando assim a ocupação do espaço central das relações sociais pelo gênero masculino, esconde uma discrepância entre o ideal de dominação masculina, expresso nos rituais e nas representações sobre a feminilidade, e as 
relações concretamente travadas na vida comunal, onde os meios físicos de controle sobre as mulheres são escassos, exigindo reforços simbólicos para manter o comportamento feminino congruente com normas definidas pela razão androcêntrica. A assimetria de gênero, um dos elementos-chave na reprodução material e simbólica da sociedade, seria naturalizada, representada como algo inerente à 'natureza' do homem e da mulher.

Segundo as regras matrimoniais comuns aos grupos Tukano e Arawak rionegrinos, a mulher deve ser sempre oriunda de uma fratria de não-consangüíneos; sendo um membro da alteridade, ela representa uma porta aberta por onde a desordem, a violência e a doença podem irromper no grupo do cônjuge. A recém-casada é alvo da desconfiança dos co-residentes do marido - uma condição que nunca cessa completamente -, mas, com o passar do tempo, sua longa convivência com o mundo dos afins também gera desconfiança entre seus próprios consangüíneos; essa trajetória gera uma espécie de limbo: a mulher é remetida à condição de um outsider, passando a viver num espaço social intermediário entre os dois grupos sem pertencer plenamente a nenhum deles; nessas condições, ela é representada como um 'não-nós', seja em termos de gênero, seja em termos de descendência, visto que a prole pertence ao grupo de agnatos de seu marido (Hill, 1993:4). Estas representações negativas não são direcionadas exclusivamente para as mulheres, mas fazem parte de um conjunto mais amplo de idéias depreciativas produzidas sobre os afins em geral, fonte atribuída da violência, do egoísmo, da trapaça e da selvageria.

Apesar dessa simbolização, Jackson demonstra que na vivência cotidiana o masculino e o feminino são esferas complementares; no âmbito doméstico a mulher gozaria de bastante poder de decisão, e a violência discursiva das produções míticas tukano expressaria as ansiedades e vulnerabilidades dos homens ante a autonomia feminina, gerando a necessidade de uma parafernália ritual, ${ }^{9}$ que busca tornar as mulheres mais obedientes e as relações de gênero mais seguras.

A abordagem de Chernella (1997) enfoca outros aspectos da mesma temática; a autora analisa um mito Wanano contado em duas versões, uma masculina e uma feminina. A versão masculina é uma variante Wanano do mito do adultério da mulher de Nhiãpirikoli com a serpente Omáwali, analisado neste texto. Na versão feminina analisada por Chernella, a ênfase não recai sobre o adultério nem sobre a ameaça ao controle masculino dos processos reprodutivos, mas sim sobre a perda de poder político pelas mulheres. Uma das propostas da análise é demonstrar que os discursos públicos que expressam posições na sociedade, longe de representarem consensos, são um produto de sentidos negociados; a versão corrente do mito expressa uma posição privilegiada do gênero masculino na cena social, na qual o homem detém o monopólio da palavra e da ocupação dos cargos de prestígio; o relativo desconhecimento da versão feminina do mesmo mito é uma demonstração da não-legitimação dos discursos das mulheres nos espaços públicos. 
No estudo dos rituais de troca Pudali, Hill (1987) tece algumas considerações sobre as relações entre homens e mulheres na sociedade baniwa, demonstrando que tal como a hierarquização dos sibs, que é mais flexível na cultura baniwa, também a assimetria de gênero é menos acentuada que entre os grupos lingüísticos tukano. $\mathrm{O}$ autor demonstra importantes diferenças entre as regras de casamento tukano e baniwa; para os primeiros os matrimônios são feitos preferencialmente entre primos cruzados bilaterais, mas oriundos de grupos lingüísticos específicos; por exemplo, os grupos Tukano, Dessano e Piratapuia priorizariam as trocas triangulares travadas entre si, garantindo, através da contratação de obrigações mútuas entre os membros do triângulo, a retribuição das mulheres cedidas; neste caso, as mulheres representam a principal via de celebração de alianças entre os afins, pois a única retribuição aceita em retorno à doação de uma esposa é a cessão de outra mulher para a mesma finalidade.

Entre os Baniwa, os acordos matrimoniais priorizam o casamento entre primos cruzados bilaterais, mas aceitam também um leque bem mais amplo de opções que compreende todas as fratrias baniwa e membros dos outros grupos lingüísticos rionegrinos; a garantia de reciprocidade não se funda necessariamente nos acordos feitos entre sibs doadores e receptores de esposas, mas sobretudo no trabalho que o genro deve prestar ao seu sogro após o casamento. O serviço do genro representa uma espécie de pagamento antecipado em retribuição à perda de um membro feminino pelos parentes da mulher que irá residir na aldeia do marido.

Dentre as conseqüências da diferença estabelecida por instituições, como o serviço do genro, pode-se apontar uma ampliação da possibilidade de escolha de cônjuges e uma menor sujeição das mulheres aos interesses políticos e matrimoniais de seus consangüíneos do sexo masculino. Onde predominam as regras de tipo tukano, a única forma de conseguir novas esposas para si ou para seus parentes é mediante a doação de uma mulher. Em razão disso, os homens teriam maior tendência a forçar suas irmãs e filhas a casamentos, mesmo indesejados por elas, para fortalecer sua influência política por meio da celebração de alianças matrimoniais com o maior número possível de afins. Tanto Hill (1987) quanto Jackson (1992) assinalam que tais regras representam mais um ideal social que uma imposição plenamente aplicável no dia-a-dia de homens e mulheres.

Sem negar a relevância das observações de Hill, geradas em pesquisa realizada entre os sibs baniwa residentes na Venezuela, o que se observa na vida dos grupos que acompanhamos no Brasil é que as mulheres não têm acesso ao corpo mais profundo de conhecimentos que orientam a condução geral e decisõeschave dos rumos da vida em sociedade; elas são excluídas do controle dos meios, particularmente os simbólicos, de produção e reprodução da sociedade, dos meios materiais e simbólicos da violência, do poder xamânico e dos cânticos, do controle do sistema de trocas matrimoniais e da convivência com seu grupo de consangüíneos 
após o casamento; exiladas dos territórios ancestrais de sua fratria, tornam-se mais sujeitas aos ataques dos seres-espíritos Yoopinai que residem no território da fratria de seu marido, o que amplia o controle masculino sobre elas. A exclusão se estende à ocupação de cargos públicos engendrados pelo contato interétnico, nos quais elas também são minoritárias.

Não existe uma proibição formal da ocupação de cargos de prestígio e do uso público da palavra pelas mulheres, e sim um desestímulo persistente que se expressa tanto no descrédito à sua capacidade de exercê-lo quanto numa socialização que desestimula a participação de crianças do sexo feminino em situações que as habilitem a liderar grupos e a conduzir situações, especialmente no domínio público. Quando as mulheres tomam a palavra em situações coletivas, os homens costumam assumir uma postura de desdém condescendente. Como exceção, citamos a apresentação de números musicais nas Conferências evangélicas facultados a mulheres ${ }^{10}$ e crianças; entretanto, elas não costumam fazer pregações públicas nesses eventos e não existem mulheres ocupando cargos de liderança religiosa, embora elas sejam chamadas a testemunhar a favor (ou contra) as qualidades de seus maridos, nas avaliações a que são submetidos quando escolhidos para estes papéis (Sampaio, 2000). As mulheres também são consideradas incapazes de memorizar as longas orações, suportar o uso de parikáe as privações que lhes permitiriam acumular malikai suficiente para desenvolver o trabalho de dono de cântico ou de xamã.

A patrilocalidade não apenas reforça o enfraquecimento sociopolítico das mulheres, que, ao contrário de seus maridos, não dispõem do apoio de seus consangüíneos para viabilizar a ocupação de cargos de prestígio na vida comunal, como também expressa o paradoxo da condição de seres que detêm o poder de procriar (crianças e roças) e domesticar a natureza pela preparação da comida e da bebida, mas que só podem desenvolvê-lo plenamente longe de seu grupo familiar. No mito de Kowai, as mulheres só podem exercer o poder criativo das flautas sagradas longe de Hipana, a aldeia primordial onde surge a humanidade; no mundo de hoje elas também só podem viver sua condição feminina adulta quando se domiciliam longe de seu grupo de consangüíneos (Hill, 1989). Sendo a alteridade a principal fonte de conflito e violência no mundo baniwa, a lealdade feminina é sempre contestável e se torna uma fonte perene de instabilidade entre seus novos co-residentes, na medida em que são entendidas como vias de fortalecimento de inimigos externos no interior da consangüinidade.

Dentre os mitos baniwa que tratam da condição feminina, citamos o do adultério da mulher de Nhiápirikoli com Omáwali, que será detalhado mais adiante; o da guerra entre Nhiãpirikoli e as mulheres pelas flautas sagradas, que deve ser interpretado como uma luta para decidir quem controla a reprodução da sociedade, e o da mulher de Pinawali, que, raptada pelo urubu, um dos animais-espíritos da morte, é forçada a tornar-se sua mulher. $\mathrm{O}$ adultério involuntário não impede que 
ela seja punida com uma genitália que se corrompe e se putrefaz. A mulher é retomada pelo marido através de um engodo que a leva a acreditar que seria bem recebida no retorno ao lar. Encolerizado pelo adultério e pela indesejável condição física da esposa que a torna inapta para a atividade sexual, o marido a abandona faminta e doente numa praia deserta, onde fica à mercê de outros afins perigosos, que finalmente a matam (Garnelo, 2001b).

$O$ relato é rico em atos de violência masculina que se concretizam na disputa pela mulher, objeto de rapto, violação, sadismo, perfídia, ciúmes e assassinato. Apesar disso, a trama enfatiza a contribuição feminina nas desgraças que lhe ocorreram e as características poluidoras de sua condição, que se estendem às adúlteras do tempo atual. A genitália e sexualidade das mulheres são consideradas como mais próximas da sexualidade dos seres da natureza. Elas são vistas como tendo parco controle sobre seus impulsos, o que gera a necessidade de uma vigilância contínua por parte dos homens.

As ligações com a alteridade tornam as mulheres um veículo da violência e da impureza; além de seus processos fisiológicos produzirem extravasamento de sangue, a própria origem da vagina é violenta: ela foi perfurada por Nhiãpirikoli com uma arma de fogo, para permitir o nascimento de Kowai; é um ato violento gerando um ser perigoso. As diferenças nas funções corporais e sociais entre os sexos recebem uma explicação cósmica e proporcionam os meios para a produção de discursos e mensagens que naturalizam as desigualdades de gênero e legitimam a necessidade do controle das mulheres pelos homens.

Na representação androcêntrica da reprodução biológica e social, a mulher tem simultaneamente o poder de criar, fecundar e transformar - elementos que no mundo baniwa estão ligados essencialmente à alteridade - mas são também fonte do caos e da desordem, disparidades que ela congrega em si mesma nos papéis sociais que desempenha e que se reproduzem em Kowai, o filho primordial, síntese da vida e da destruição do mundo. As mensagens míticas sobre a condição feminina enfatizam principalmente as catástrofes desencadeadas por sua insubordinação e pelo não-cumprimento de seus deveres.

As condutas femininas que aparecem nos relatos míticos expressam alguns doș mais negativos comportamentos do mundo baniwa: curiosidade excessiva, dificuldade para controlar seus impulsos, particularmente os sexuais, disponibilidade para trair os princípios morais e os interesses da família do marido, instabilidade de opiniões ${ }^{11}$ e desleixo. Nas conversas cotidianas, as mulheres costumam ser situadas na categoria manhene, termo usado em português para descrever alguém que 'não pensa', ou seja, uma pessoa irrefletida e egocêntrica, com escassa capacidade de reflexão sobre as conseqüências de suas atitudes. A essas características de comportamento agrega-se o cheiro ${ }^{12}$ das secreções femininas, que tem o poder de simultaneamente irritar e atrair espíritos das águas e das 
florestas, com intenções de cunho agressivo e sexual. Tais condições são particularmente propícias à eclosão da doença na mulher e em sua prole, podendo se estender ao restante da sociedade.

Retomando as premissas de Jackson (1992), diríamos que essas imagens terrificantes expressam a carência de meios para inibir comportamentos desviantes de quem decida transgredir sistematicamente as regras de boa conduta. Em sociedades sem poderes centralizados de coerção sobre seus membros, existem poucos meios individuais de controle das mulheres e outros transgressores por suas famílias e/ou por seus maridos. Neste contexto, as crenças sobre doenças e cura, bem como sobre a responsabilidade feminina por sua eclosão, operam como vias coletivas de controle, capilarmente distribuídas no corpo social; são meios simbólicos de coação buscando adequá-las às normas da sociedade.

Uma interpretação como esta não é hegemônica na sociedade baniwa; o monopólio masculino da palavra nos espaços públicos ritualizados propicia maior circulação das versões masculinas dos eventos, que são sancionadas como explicações legítimas e autorizadas a representar a vida em sociedade. Os homens são os porta-vozes das verdades públicas sobre a origem da doença, do infortúnio, das estratégias de cura e de cuidados; as divergências produzidas em torno desses conteúdos discursivos costumam estar ligadas às disputas de sibs, isto é, de versões masculinas de cada sib, e não às disputas de gênero.

Os homens monopolizam as atividades xamânicas e de donos de cânticos; ${ }^{13}$ esse último tipo de especialista encarrega-se dos rituais kalidzamai de nascimento e da menarca, reservando para seu gênero o conhecimento sobre as formas de neutralizar a periculosidade dos seres e locais onde a alteridade se manifesta. As mulheres entrevistadas na pesquisa insistem que as explicações corretas sobre as doenças e cuidados com a feminilidade só podem ser obtidas com os donos de cânticos, que oficiam estes ritos nos momentos de liminaridade. Não encontramos, entre as mulheres baniwa, relatos similares ao recolhido por Chernella (1997).

A condição feminina se integra apenas parcialmente na dimensão vertical do cosmos onde ocorre a sucessão das gerações e se garante a primazia da paternidade que controla a descendência. A inserção da mulher tem mais afinidade com a dimensão horizontal onde se processam os casamentos. A ausência de um elaborado ritual de passagem feito nos moldes masculinos dificulta, aos olhos do grupo, a internalização pelas mulheres dos valores caros à cultura baniwa e a investidura no papel de membro pleno da sociedade, o que exige a instauração de controles familiares duradouros.

Os rituais femininos de passagem objetivam mais à proteção da mulher dos ataques de seres-espíritos do que à sua recategorização como membro adulto da sociedade. As jovens permanecem na condição liminar de puberdade por vários anos e as perdas mensais de sangue as colocam em situação de fragilidade, 
demandando periódicas intervenções masculinas feitas através de cânticos, para evitar os descaminhos de uma condição que nunca desaparece completamente até que sua menstruação cesse. A consolidação da maturidade feminina é lenta e só se completa quando a mulher casa e se afasta da moradia de sua família de origem; esta é a nova condição que a habilita a iniciar o desempenho de papéis adultos que só podem ser plenamente exercidos quando sua sexualidade for disciplinada e enquadrada na moldura dos deveres conjugais.

Para Hill (1989), a mulher púbere é situada numa condição de proximidade dos recém-mortos, particularmente aqueles que sofreram perda de sangue. Os produtos da feminilidade são poluidores: o sangue menstrual sintetiza as violências sexuais inextrincavelmente ligadas à produção biológica dos indivíduos; a umidade das secreções femininas é assimilada à dos animais aquáticos causadores de doença ${ }^{14}$ e dos espíritos da morte Inyaime; suas secreções produzem cheiros atrativos para os Yoopinai. Umidade também é sinônimo de presença anormal de água na diarréia, nos inchaços, nas hemorragias, assim como nos catarros e secreções purulentas de toda ordem. A cura exige 'secar' o doente nos rituais kalidzamai e prevenção da doença pode ser feita nos rituais de passagem pela ação do calor dos chicotes e plantas urticantes. No cotidiano a prevenção é feita pela pimenta que tempera o peixe e protege as pessoas, ainda que de modo imperfeito, da umidade e periculosidade do alimento.

A observação da vida cotidiana nas aldeias evidencia um discreto, mas eficiente, controle dos homens (e das mulheres mais velhas) sobre o comportamento feminino, expresso numa vigilância permanente do cumprimento das regras de higiene pessoal e do preparo de alimentos e na limitação do contato com homens de fora da aldeia, particularmente os brancos. Nas Conferências Evangélicas, ${ }^{15}$ este controle deixa de ser discreto, passando a uma vigilância explícita, feita por um corpo de 'guardas da Conferência' que têm entre suas principais funções a de fiscalizar o fervor e a participação das mulheres nos cultos, além da de empreender uma vigília permanente durante a noite, quando tentam flagrar atos ilícitos que possam ser perpetrados no escuro. Nessas ocasiões, o controle sobre as secreções e excreções corporais se intensifica manifestando-se na delimitação de espaços e horários específicos destinados à higiene corporal feminina. Pode-se dizer que nas Conferências ocorre uma publicização e uma exacerbação do controle habitualmente exercido no cotidiano familiar.

Rituais femininos de passagem, representações de doença e cura e ocupação de funções de responsabilidades conjugais implicam a legitimação da assimetria de gênero, comportando uma ativa colaboração das mulheres mais velhas na manutenção de normas sociais, que se legitimam pela culpabilidade cósmica da mulher. Apesar disso, o gerenciamento cotidiano da vida familiar pode colocar a esposa em oposição às posições públicas do marido; ambições políticas masculinas 
podem se concretizar apenas por meio da prodigalidade exercida entre seus liderados. Como as alianças políticas costumam ser consolidadas através da distribuição de presentes, este fluxo pode ameaçar a qualidade de vida de sua família, levando a esposa a tentar limitar a permanente evasão das riquezas; essa atitude é interpretada como sovinice, mais uma das falhas de caráter atribuídas às mulheres.

Obviamente, as regras de conduta existem não apenas como um meio de opressão de mulheres e jovens. Para os homens tais regras também constituem uma pesada carga de responsabilidades que os obriga não apenas a zelar por sua adoção pelos outros membros da sociedade, mas também a aplicá-las para si próprios, sob pena de comprometimento de sua credibilidade e legitimidade no exercício de cargos políticos. Nessa sociedade o bom desempenho de funções públicas está ligado ao rigoroso cumprimento de normas morais, usadas também como critério de avaliação das chefias. Remetemos para os capítulos seguintes o detalhamento das contradições que envolvem o exercício da chefatura pelos homens.

No julgamento cotidiano, as mulheres são consideradas como mais pragmáticas, mundanas, impulsivas, sovinas e maledicentes, tendendo a obter o que desejam por intermédio da astúcia e da mentira. Tais características de comportamento contradizem o ideal de franqueza, correção, generosidade e honestidade exigido aos homens. Essa contradição aparente recobre um mecanismo de cooperação entre os cônjuges, pois o comportamento menos rigoroso e mais flexível das mulheres - próprio da alteridade que as constitui - permitiria aos maridos efetivar, por intermédio das ações de suas esposas, atos socialmente condenáveis que eles não poderiam realizar diretamente sob pena de perda de prestígio no exercício de suas funções públicas. Os boatos e maledicências espalhados pelas mulheres cumprem funções políticas, pois visam manipular a opinião pública local e desencadear ações para obter fins deliberados, destinados a atender não apenas a seus interesses pessoais, mas também aos das facções nas quais seus maridos se alinham.

As fofocas promovem uma ritualização e circunscrição dos conflitos; quando veiculadas pelas mulheres, tornam possível aos seus maridos ou a seus consangüíneos exprimir, através delas, opiniões e insatisfações sem o risco de um confronto dịreto; elas possibilitam que os homens se escudem no nicho do discurso não-autorizado, desprovido de poder público, mas não de verdade ou de validade, para expressar posições antagônicas, sem o perigo de retaliação com Manhene ou de censura social ${ }^{16}$ e sem a renúncia à dignidade de seu status. A eficácia social dos boatos é garantida pelas relações materiais ou simbólicas que lhes servem de contexto; costumam ser a contraparte negada do discurso formalizado das chefias e cumprem também um papel de questionamento e fragilização das relações sociais, mantendo a demarcação das diferenças entre os grupos e facções constitutivas da estrutura social (Altman, 1994). A concordância das mulheres em operar como 
'válvula de escape' das severas restrições morais impostas aos homens indica uma complementaridade de papéis entre os cônjuges e uma partilha dos interesses do grupo familiar do marido que se estendem a si próprias e à sua prole. Aqui, a assimetria de gênero é indissociável da complementaridade e reciprocidade estabelecidas entre homens e mulheres.

A essas considerações cabe acrescentar também um breve comentário das relações entre Amaro, a primeira mulher, e os brancos; como demonstra a literatura (Wright, 1993/1994, 2000), (Hill, 1989) e a observação participante feita por mim, os brancos foram assimilados a Omáwali ou Oliámali, o protótipo das serpentes ancestrais agressivas e a Kowai; ambos pertencem à turbulenta zona de relações fronteiriças entre a humanidade e a sociedade dos seres-espíritos da natureza; a mulher é representada em íntima interação com os mesmos, o que enfatiza sua posição ambígua, de ocupação de um espaço periférico, transicional entre o mundo baniwa e a alteridade formada por humanos ou não-humanos.

Os eventos patológicos costumam ter uma dupla (ou às vezes múltipla) origem, seguindo um padrão em que a primeira manifestação do agravo é sucedida por um relato mítico subseqüente, que reafirma a reprodução da doença e/ou infortúnio no mundo de hoje. Essa movimentação reflete também concepções subjacentes de doença, como uma seqüência de ações reiteradas, cujo efeito cumulativo culmina na eclosão dos sintomas como o produto final do processo.

\section{Os sentidos da origem das doenças - o eixo vertical do cosmos}

A origem das doenças no mundo baniwa remete à organização do cosmos, que comporta um eixo vertical, representado pela continuidade de gerações, desde o ancestral criador Nhiãpirikoli até os homens do tempo atual; o plano horizontal conecta a reprodução da doença na vida social às relações político-históricas de aliança e hostilidade entre sibs e fratrias (Hill, 1989), (Wright, 1993/1994, 1996). A lógica produzida pelos relatos míticos de origem de doenças permite agrupá-las em três grandes troncos, que geram a taxonomia reconhecida pelos informantes.

\section{Doenças do tronco mítico de Nhiãpirikoli}

$\mathrm{O}$ mito ${ }^{17}$ que vamos relatar trata de um adultério ancestral cometido pela mulher de Nhiãpirikoli com a serpente ancestral, Omáwali ou Oliámali, pai de todos os peixes, inimigo mortal dos ancestrais dos humanos. Nhiãpirikoli constata o adultério e se vinga matando a serpente com uma zarabatana. Como ele erra nas duas primeiras tentativas, as flechinhas da zarabatana caem a esmo e se transformam em cobras venenosas (surucucu, jararaca e coral), que, até então, não existiam. 
Em seguida, ele mira para o alto e atira; num movimento elíptico a flecha sobe, bate no céu e retorna; a serpente, que assumira a forma de um homem branco, é atingida nas espáduas, mas não morre. Em nova tentativa a flecha penetra no lombo, na altura dos rins, matando-a. A serpente morta solta-se do corpo da mulher e afunda no rio; ao fazê-lo, solta na água seu sêmen. Das flechas de zarabatana que perfuram e matam Omáwali surge o grupo de doenças, Walama.

A vingança prossegue, intentando atingir agora a mulher. Nhiãpirikoli amputa o pênis da cobra morta e corta-o em quatro pedaços que são transformados em peixes; ele os assa e serve à esposa, que engravida dos peixes-pênis. Ela tenta expeli-los vomitando e consegue eliminar três deles, mas o quarto permanece e a gravidez se consolida. Dessa fase do mito surge a explicação da origem do grupo de doenças Whiókali.

A gravidez se prolonga e a criança/serpente não nasce completamente; perfura a clavícula materna, por onde sai para o mundo exterior, mas mantém seu corpo enrolado no pescoço da mãe e a cauda presa em seu útero. Durante a gravidez interminável, a mulher vê sua rotina diária seriamente perturbada pelo apetite voraz do filho e passa por uma série de desventuras em suas tentativas de se desvencilhar da indesejável situação. Diversas peripécias se sucedem na busca da cobra de satisfazer seus apetites e evitar a fuga da mãe. Nesse ínterim o filho cria os cânticos rituais para tratar picada de cobra e define algumas regras de periculosidade (reima) das frutas e outros alimentos interditados às vítimas de tais agressões. Por fim, a mãe consegue fugir do incômodo filhote, sendo punida por ele, que a transforma num peixe. O filhote/serpente migra para o Baixo Rio Negro, onde se torna o pai dos Yoopina $1^{18}$ daquela região. Esses seres são importantes para a presente discussão, pois deles os brancos roubarão, num tempo posterior, o petróleo - para fazer gasolina - e óleo diesel, combustíveis que movimentam as máquinas para fabricar as mercadorias, que eles aprenderam a fabricar com Amaro e que veiculam as doenças trazidas pelo contato.

Figura 2 - Representação desse grupo de doenças, em relação à origem mítica

\section{ADULTÉRIO ANCESTRAL OMÁWALI X MULHER DE \\ NHIÄPIRIKOLI}

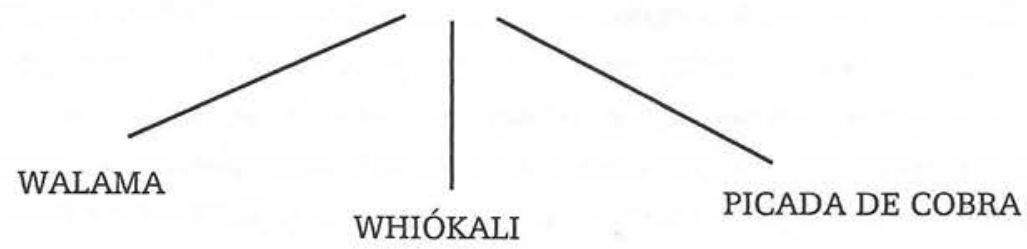


Walama, Picadas de cobra e Whiókali formam três grupos taxonômicos subdivididos em diversas outras manifestações patológicas. Uma descrição detalhada da taxonomia de doenças baniwa pode ser obtida no Manual de Doenças Tradicionais Baniwa (2001) e em Garnelo \& Wright (2001). Aqui serão resumidas apenas as características de cada grupo, que interessam à presente discussão.

Walama: segundo Garnelo \& Wright (2001), esse termo tanto designa os sintomas de doença como seu veículo, as flechinhas mágicas, que podem ser atiradas por pajé, pelos seres-espíritos Yoopinai ou pelos astros celestes, provocando dor súbita e aguda, tipo perfurante que aparece em locais diversos do corpo, sobretudo nos ombros e na região lombar. O meio de difusão do Walama é o ar, mas os trovões, fonte essencial de poder dos pajés poderosos, podem ser mobilizados para causar formas graves da doença. Os Baniwa identificam diversos tipos de Walama, como Kainoakanaadali, Walamanheetta, Owa haiko, Katodakanapa etc.; todos eles têm em comum serem manifestações de dor súbita em pontada, imitando a dor gerada pela penetração das flechas mágicas da zarabatana usada por Nhiãpirikoli para matar Oliámali. Sua capacidade de provocar doenças se deve ao poder mágico Malikai que elas materializam; é um poder partilhado pelo pajé - presente em seus instrumentos de trabalho, como o maracá, osso de soprar paricá, e suas pedras mágicas - e por seres espíritos como os Yoopinai, quando desejosos de causar dano a alguém.

Longe de se constituir evento fortuito, as picadas de serpentes peçonhentas devem ser entendidas como produto do mesmo contexto das relações conflituosas com a alteridade, expressas nesse mito de origem. Associado ao fato de que as cobras com veneno surgem da agressão mal-sucedida de Nhiãpirikoli, apresenta-se o fato de que serpentes e peixes pertencem, na cosmovisão Baniwa, a um grupo único de animais que, desde os primórdios dos tempos, disputam o domínio do mundo com os humanos.

$\mathrm{O}$ terceiro grupo de doenças remete à periculosidade dos peixes e ao descumprimento de regras de preparo e consumo destes alimentos. Dessas, o representante mais expressivo é Whiókali, um conjunto de manifestações consumptivas que cursam com diarréia crônica, emagrecimento e enfraquecimento geral, que, se não forem tratadas, podem matar a pessoa. A doença derivaria da ingestão de peixe cru ou preparado inadequadamente por mulheres pouco higiênicas; o veículo da doença é o cheiro (pitiú) característico do peixe. O portador dessa patologia elimina, na diarréia, uma substância gosmenta que evoca o sêmen de Oliámali e em seu intestino cresce uma cobra que, se não for exterminada, termina por matar seu hospedeiro. Porákali é um tipo de diarréia que acomete jovens em estado liminar da puberdade que não cumprem as normas dietéticas prescritas especificamente para esta fase da vida. Segundo Wright (1994), malformações congênitas também são atribuídas à agressividade dos peixes. É a 
interação entre preparação inadequada de alimentos - o peixe ou caça que incompletamente limpos ou mal cozidos manteriam seu cheiro específico que pode ocasionar essa doença - e a falta de cumprimento de restrições alimentares ritualizadas em períodos de liminaridade que desencadeia as manifestações deste grupo de patologias.

As doenças Whiókali sintetizam a guerra permanente entre humanos e cobras/peixes/espíritos das águas e evocam desvios no comportamento feminino, que vêm se reproduzindo ao longo dos tempos. No mito, Nhiãpirikoli se vale de um elemento da cultura, a zarabatana, para matar Omáwali; no mundo atual, os meios utilizados para controlar a irrupção do poder agressivo das serpentes no domínio humano são os cânticos kalidzamai (nos quais o xamã mata simbolicamente as serpentes/peixes), as restrições alimentares e sexuais e as regras de purificação do corpo e dos alimentos.

A origem das doenças desse grupo remete às relações conflitivas com a alteridade, representada nesta fase dos ciclos míticos baniwa pelos animais afins com os quais Nhiãpirikoli guerreia e troca mulheres. A morte da serpente, cujo adultério ameaçava a descendência humana futura, consolida a hegemonia da humanidade sobre a Terra e garante sua subsistência cotidiana pela pesca. $\mathrm{O}$ mito trata da própria possibilidade de existência humana, obtida através da vitória nas relações guerreiras travadas com os seres-espíritos animais. Tais guerras se atualizam na caça, na pesca e nas tensões cotidianas que redundam em doenças provocadas pela agressividade animal.

\section{Doenças do tronco mítico de Kowai}

Kowai personifica o segundo tronco mítico de origem de outro conjunto de doenças. As características desse ser, de importância central na cosmogonia, já foram bem analisadas por Wright (1999) e por Hill (1989), de modo que não vamos nos estender sobre ele. Aqui tentaremos analisar apenas algumas implicações contidas no mito que são importantes para a patogênese baniwa.

O personagem é responsável pelos saberes ligados ao ritual de iniciação masculina, um dos pilares da cultura baniwa, pela origem das rezas, sopros Hiwiathi, remédios e venenos. Este ser, polimorfo e ambíguo por excelência, concentra em si próprio a doença e a cura, a reprodução (ritual de iniciação masculina) e a destruição da sociedade (doenças mortais); faz a junção entre natureza e cultura, entre violência, canibalismo, assassinato e comportamento socialmente aprovado que garante a reprodução do mundo baniwa.

Devido a sua extrema periculosidade, ele havia sido banido do mundo ancestral por seu pai Whiãpirikolie retorna para ensinar a seus quatro jovens irmãos o rito de iniciação masculina. Como parte das regras rituais, Kowai estabelece um 
período de rigoroso jejum para os iniciandos. Ao ser desobedecido por três deles, reage com fúria e canibaliza os transgressores. $\mathrm{O}$ atribulado rito é finalizado apenas com o mais jovem dos rapazes, o único que havia mantido o jejum prescrito. Durante o período de preparação do rito, ele ensina para Dzooli, um dos irmãos de Nhiäpirikoli, as rezas para tratar doenças; o outro, Eeri, é enganado e aprende procedimentos próprios para causar doenças e morte, os sopros Hiwiathi. Outra conseqüência secundária da desobediência dos jovens é que Kowai não finaliza os benzimentos que fazia sobre a alimentação, temperada com pimenta, que se destinava aos iniciandos ao final de seu período de jejum. Como o procedimento não foi completado, a periculosidade dos alimentos e da pimenta não foi amenizada. É deste episódio mítico que se origina a necessidade de restringir o uso de diversos alimentos, entre os quais a pimenta e os peixes, pelos doentes.

Cumprindo as premissas da Likoada, Nhiápirikoli procura vingar-se, matando Kowai pelo fogo, único elemento capaz de destruir seu corpo imortal. Da fumaça que se desprendeu do corpo de Kowai saíram os mais perigosos sopros Hiuiathi, e de suas cinzas nasceram, simultaneamente, as palmeiras das quais são feitas as flautas que daí por diante passaram a orientar os rituais de iniciação masculina e os venenos Manhene, uma das principais categorias de doença baniwa, considerada, na representação dos informantes, como o agravo mais freqüente e mortal em sua sociedade.

As principais categorias de doença aqui agrupadas são:

\section{Manhene}

Vocábulo cuja tradução literal é 'ninguém sabe' (Wright, 2001); ${ }^{19}$ é um termo traduzido para o português como 'veneno da região', que conota simultaneamente o envenenamento da comida, bebida, objetos pessoais e orifícios naturais de um inimigo, os sintomas provocados por estas substâncias no corpo da pessoa e o veículo do envenenamento, seja ele uma planta ou outra substância (material ou simbólica) utilizada para causar dano à vítima. Para os Baniwa essa é a mais grave e freqüente das doenças; a primeira morte no mundo ancestral, que própagou a mortalidade para os seres humanos foi causada por Manhene, o que permite aquilatar a importância do veneno na nosologia do grupo (Garnelo \& Wright, 2001).

As razões atribuíveis a um envenenamento podem ser diversas, mas os motivos mais comumente alegados são a vingança pela morte de um parente e a inveja dos bens e sucesso de um membro do grupo; Wright (no prelo) assinala também, como razões para uso de Manhene, o ressentimento causado por trocas não retribuídas ou por maledicências e a perda de controle dos impulsos pelo envenenador, levando-o a reincidir nessas práticas. 
Segundo as formas de classificação baniwa, existiriam três grandes grupos de Manhene, todos originados de Kowai, pois se espalharam no mundo a partir de suas cinzas sopradas por um vento que era a expressão do poder mágico do personagem ou das plantas que nasceram no local onde ele foi queimado. A herança do veneno é um ato de vingança de Kowai, deixado como retribuição por seu assassinato (likoada). Dessa forma, temos:

- Venenos do cérebro de Kowai: para os informantes, esses venenos seriam originados do cérebro queimado e transformado em cinza; eles geram distúrbios de comportamento com abandono das atitudes consideradas compatíveis com as regras de convivência social. O perigoso cérebro de Kowai atacaria a razão humana, gerando uma ruptura com a condição de vida tribal e instituindo o domínio da natureza na alma do doente, que é remetida à animalidade expressa no seu comportamento selvagem. As doenças são reconhecidas de acordo com o tipo de comportamento adotado pela vítima: no Powekaimi, ela se comporta como um macaco; no Manhene tipo Katsirikaimi, o envenenado adota o comportamento de um animal aquático e assim por diante. Este tipo de Manhene caracteriza um evento em que a ação agressiva de um ser humano sobre outro provoca uma 'baixa' nas fileiras humanas, ao jogar o doente na condição animal provocada pelo efeito do veneno.

- Venenos do fígado de Kowai: seriam oriundos de plantas nascidas no local onde Kowai foi queimado, sendo depois transplantadas para outros lugares por feiticeiros interessados em dispor deles. Os informantes situam lugares especiais onde tais venenos proliferam, em seu próprio território, no Brasil, e numa serra na Venezuela, locais escolhidos por Nhiãpirikoli para guardar 'todos os venenos do mundo'. As manifestações dos venenos vegetais são de dois tipos básicos: um quadro agudo de hemorragia digestiva em que o envenenado pode morrer em poucas horas, vomitando e defecando sangue e os quadros crônicos, tipo consumptivos, que evoluem com fraqueza, emagrecimento, palidez, desânimo e, por vezes, perversão alimentar tipo geofagia, levando vários meses, ou mesmo anos, para matar o envenenado.

- Venenos dé pêlo de Kowai: estes agentes agressores ora são representados como pêlos, ora como espinhos que perfuram e penetram o corpo da pessoa. Essa indistinção se deve à idéia de que o corpo de Kowai era peludo, principalmente quando ele assumia a forma da preguiça preta Wamo. Entretanto, sua pelagem não era como a dos animais comuns, era formada por espinhos venenosos, dotados da capacidade de penetrar o corpo das pessoas e nele transitar até encontrar e perfurar o coração da vítima, que morreria por perda de sua essência vital. Os venenos considerados pêlos de Kowai provocariam dor aguda no peito e na cabeça, febre, frio e morte rápida. 
Em tese, qualquer pessoa do sexo masculino pode conhecer e utilizar venenos. O tema é bem conhecido entre as pessoas comuns das aldeias, que dominam saberes sobre contravenenos e outras formas de tratamento. Existe restrição de seu acesso às mulheres, tanto em função de sua ligação com os rituais de iniciação masculina, vedados ao sexo feminino, quanto pela potencial capacidade de disseminação do veneno no meio social através do corpo feminino. Os informantes costumam afirmar que, antigamente, todo jovem recebia informações básicas sobre venenos e contravenenos no ritual de iniciação pubertária, o que, segundo dizem, já não ocorre nos dias de hoje. Ao lado desse conhecimento disseminado no corpo social também existem especialistas, denominados de donos do veneno (manhene iminall), como os estudados por Wright (no prelo). Segundo o autor, a trajetória percorrida pelos donos do veneno torna-os gradativamente incapazes de controlar seus impulsos homicidas e a se afastar, cada vez mais, da natureza humana, de tal forma que sua alma se transforma na de um animal, em geral um macaco Eenunai; só os xamãs são capazes de reconhecê-los.

No ideário de comportamento social baniwa, o uso de veneno seria restrito aos afins e, embora as hostilidades entre consangüíneos possam ser bastante evidentes, os informantes relutam em admitir a existência de uso de veneno e sopro entre agnatos. A observação participante demonstra, porém, que as relações entre tios e sobrinhos, irmãos e primos podem ser bastante tensas, envolvendo inveja e disputa de prestígio que podem redundar em acusações veladas de uso de Manhene. Caso haja morte, instala-se um ciclo de vinganças que pode se perpetuar por gerações. Existe uma forte censura social ao uso de veneno entre consangüíneos, mas as informações disponíveis mostram que um parente desejoso de vingança pode contratar os serviços de um não-consangüíneo para envenenar seu desafeto; além disso, as formas de uso do veneno (na comida, na bebida, no nariz, quando a vítima dorme, ou em seus objetos pessoais) indicam a necessidade de um convívio próximo entre agressor e vítima para que esse tipo de agressão possa ser perpetrada com sucesso.

\section{Hiwiathi}

É um segundo grande grupo de doenças, traduzido para o português como 'sopro'. Trata-se de tipos de encantamentos, rezas ou cânticos do mal, manejados por pajés ou por benzedores, não sendo impossível que pessoas comuns conheçam alguns sopros e que possam utilizá-los contra os seus desafetos. Tal como os venenos, um conhecimento básico sobre os sopros era tema de aprendizado nos rituais de iniciação masculina. Segundo Garnelo \& Wright (2001), a enunciação dos sopros segue a mesma lógica dos cânticos, dos quais são opostos simétricos; eles nomeiam objetos do mal, como certos tipos de pássaros, peixes, plantas venenosas, espíritos dos mortos e outros seres agressivos, visando causar dano à vítima; seu veículo 
essencial é a fumaça do cigarro soprada no ar. Os sopros foram criados por Kowai, que, por ocasião do primeiro ritual de passagem, enganou um dos irmãos de Nhiãpirikoli, afirmando que se tratava de orações para fazer o bem; a partir daí, foram reproduzidos para a humanidade que sucedeu aos ancestrais.

Esta categoria engloba um subconjunto muito heterogêneo de manifestações patológicas ${ }^{20}$ de pele (Maalittalemi, Koliri ipákam), do tecido celular subcutâneo e músculo-esquelético (Kooloipemi, um tipo de cisto, Komadeewhémi, hérnia inguinal e escrotal), hemorragias diversas (Iraidalimı), manifestações oculares agudas tipo conjuntivite, que podem levar à cegueira (Mathikaim) e Dezeewhemi, ${ }^{21}$ um conjunto de manifestações consumptivas de fraqueza, emagrecimento, mal-estar geral e palidez que costuma se confundir com Manhene. Um grupo especial de Hiwiathi deve ser assinalado: é aquele que provoca doenças da feminilidade, como hemorragias pós-parto, excesso de menstruação, morte pré e pós-natal do feto, infertilidade e falta de leite materno; essas doenças são todas geradas por sopros que 'estragam' a mulher e costumam decorrer de ciúme de pretendentes desprezados.

Doenças e infortúnios provocados por Yoopinai dada sua ambigüidade, essa categoria de doença poderia ser agrupada tanto no tronco mítico de Nhiãpirikoli quanto no de Kowai, em função do caráter transitante desses espíritos da floresta, das águas e do ar, que aos olhos humanos tomam a forma de lagartos, peixes, cobras, borboletas e vivem em estado de guerra latente com os homens. Alguns Yoopinai são descendentes dos Awakaruna, uma espécie de curupiras da floresta, outros são antigos humanos que foram reduzidos à condição animal; o traço que une os dois grupos é o uso irresponsável e indiscriminado de Malikai, sob cujo poder sucumbiram, provocando enlouquecimento e punição subseqüente com a perda da forma humana.

Desde os tempos ancestrais as relações de reciprocidade entre humanos e Yoopinai se caracterizam como de tipo negativo: geram roubos e agressões ora perpetradas por humanos e retribuídas por eles, ora o contrário, redundam em doenças e infortúnios diversos, como acidentes e tempestades. Os locais considerados como sendo suas moradias obedecem à mesma distribuição territorial dos sibs e fratrias baniwa, reforçando a idéia de uma socialização similar à humana. Sua origem mítica permite classificá-los como um tipo de 'gente imperfeita', que perdeu a forma física humana devido a um comportamento arrogante e impaciente, que os levou a desobedecer às regras de aprendizado xamânico estabelecidas por Kowai. Seu comportamento representa uma espécie de protótipo de afins violentos e socializados de modo incompleto, mas sua essência permanece similar à dos humanos, demonstrando uma continuidade metafísica entre estes seres da natureza e a cultura baniwa (Viveiros de Castro, 1996).

Os Yoopinai podem causar doenças de pele (Hiipami, Paixakada, Kopiñhaim, Paapakapemı), cegueira (Hipolechi, Hirimaka); também podem flechar 
os humanos com flechinhas Walama, causando os sintomas típicos desta categoria de doença. Eles são responsáveis ainda por tempestades, alterações climáticas passíveis de causar dano aos seres humanos, além de infortúnios diversos, especialmente o que se costuma classificar corriqueiramente como acidente: uma árvore que tomba e atinge alguém, fraturas, naufrágio de canoa etc.

Tais seres-espíritos exercem funções de censores morais nessa sociedade; o não-cumprimento de regras de higiene, ${ }^{22}$ pensamentos e sonhos libidinosos, a falta de sobriedade e cumprimento das restrições alimentares, desobediência e inveja são comportamentos passíveis de atrair seu ataque. Sonhos libidinosos e/ou com acidentes são premonitórios de ações de Yoopinai; entre os evangélicos, considerase que a melhor forma de evitá-los é a confissão pública do sonho e a realização de rituais de purificação que envolvem restrição alimentar, sexual e penitências religiosas.

Graficamente, esse conjunto de doenças pode ser expresso da seguinte forma:

Figura 3 - Conjunto de doenças geradas a partir de Amaro e Kowai

\section{NHIÁPIRIKOLI X AMARO}

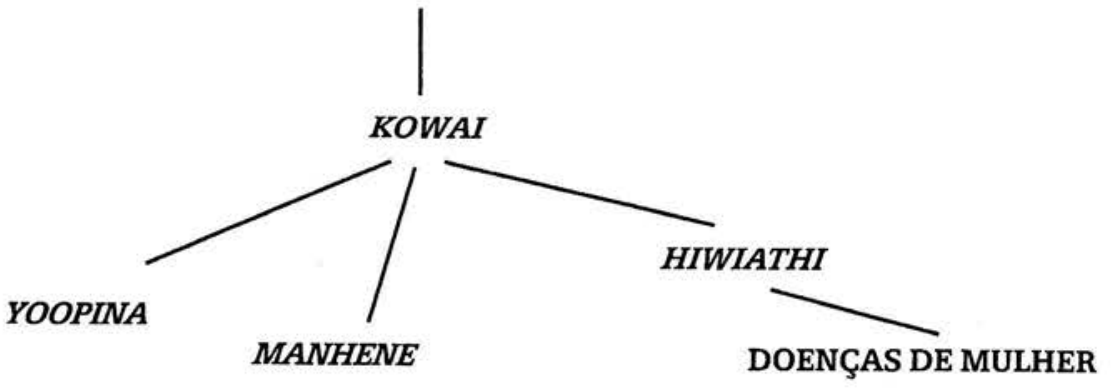

O ciclo mítico de Kowai enfatiza a obediência das gerações mais jovens; sua morte pelo fogo é conseqüência direta da indisciplina dos jovens iniciandos que desobedecem às regras de restrição alimentar do ritual de reclusão pubertária. Essa morte/vingança desencadeia outro conjunto de ações, o estabelecimento das regras de iniciação masculina, nas quais os ideais de obediência são novamente enfatizados e saberes sobre sopros e venenos, reproduzidos. O assassinato de Kowai o retira do plano humano e o transfere para o da natureza; seu corpo se transforma tanto na palmeira da qual devem ser feitas as flautas sagradas dos rituais de iniciação, quanto nos venenos de origem vegetal e animal que expressam a discórdia entre os humanos. $\mathrm{O}$ veneno, vingança de Kowai, traz o caos à ordem social e seu uso fere as regras do bom convívio humano, atingindo preferencialmente os que desobedecem as regras de purificação/proteção corporal. Sob esse ponto de vista, a 
vingança de Kowai é o oposto simétrico da ordem social instaurada pelas flautas. É fora dos limites da sociedade humana que Kowai estabelece as regras da ordem e o caos social; o ciclo mítico se completa em torno de um elemento bem definido na rede de relações de causa e prevenção de doenças, a desobediência.

\section{Amaro e as doenças de branco}

As doenças oriundas do contato: O termo 'doenças de branco' (Ialanawi idzmikathı) é usado pelos informantes para caracterizar doenças cujo potencial epidêmico seja evidente; eles as traduzem para o português como 'doença passageira', enfatizando a capacidade da doença de 'passar' de uma pessoa para outra, com rapidez, num curto período de tempo, configurando micro ou macroepidemias. ${ }^{23}$ Embora a designação doenças de branco se refira às doenças trazidas pelo contato interétnico, as nosologias aqui agrupadas pelos informantes não têm uma correlação necessária com os diagnósticos biomédicos, mesmo quando ambos utilizam a mesma denominação, pois não há equivalência entre a lógica classificatória do sistema biomédico e a taxonomia baniwa. Por exemplo, o termo Wheetsié traduzido como gripe e descreve manifestações agudas de coriza, febre e dor de cabeça, mas também existe o vocábulo Iitsipemi, igualmente sinônimo de gripe, mas descrevendo quadros de tosse crônica, que na taxonomia biomédica poderia equivaler tanto à coqueluche quanto à tuberculose. Em função disso, consideraremos que o que está agrupado sob o rótulo de doenças de branco são as representações baniwa sobre o tema, ou seja, a forma como eles interpretam a expressão desses eventos patológicos.

As doenças de branco ${ }^{24}$ foram incorporadas à taxonomia de doença do grupo, mas são eventos pertencentes ao espaço da alteridade, isto é, a um caso específico de alteridade representada pelos não-índios. Internamente, o lugar de classificação das doenças de branco também se mostra problemático, pois elas tanto podem se configurar como um grupo específico de doenças ligado às relações interétnicas, quanto podem ser distribuídas em outros nichos da taxonomia baniwa. Por exemplo, Dzeewhemi é reconhecida como tuberculose, que teria surgido após o início do contato interétnico, mas também pode ser reenquadrada como Manhene ou Hiwiathi. Iraithooli, uma diarréia com sangue de tipo microepidêmica, é reconhecida como doença que se origina nas idas à cidade, mas pode ser também agrupada entre as Whiókali, e assim por diante.

Tal ambigüidade é congruente com a representação do branco na cosmovisão baniwa, na qual costuma aparecer mesclado a representantes perigosos da alteridade. Essas doenças também estão ligadas a Amaro, a primeira mulher, que é considerada como mãe ancestral dos brancos, a quem teria ensinado a fabricação das mercadorias, após ser exilada do território baniwa. Jonhatan Hill (1989) 
identifica uma associação deste personagem com o calor, com as febres, comuns nas doenças trazidas pelo contato, e com ferramentas, motores de popa e armas de fogo, cujo funcionamento gera calor e cuja fabricação exige que esses materiais sejam expostos a altas temperaturas que ficariam retidas no objeto.

O mito que explica a origem do Kooname, doença que em português é chamada de malária, exemplifica a complexidade das recriações culturais feitas pelos baniwa. Segundo o relato, o Kooname surge por ocasião do assassinato de Konáwheri, o 'dono' do Timbó; esse personagem é um dos Eenonai, os macacos-espírito ancestrais, afins de Nhiãpirikoli e 'donos dos venenos'. Os filhos de Konáwheri matam e comem um dos irmãos de Nhiãpirikoli e este se vinga introduzindo o gavião Kamattawa, criado com fragmentos do coração do morto, na aldeia de Konáwheri. Um dia, o gigantesco gavião prende o velho sogro de Nhiápirikoli em suas garras, carregando-o pelos ares em direção ao Rio Uaupés. Nhiãpirikoli finge que atira no gavião, mas mata Konáwheri com uma flechada, fazendo o assassinato parecer acidente. A ave estraçalha o corpo venenoso do velho e sua urina corrosiva se espalha, cavando buracos nas pedras onde também se depositam os restos de seu corpo morto.

Nessas 'panelas de pedra' ficariam armazenados os venenos que provocam a malária; quando começa o período de seca, o sol quente os evapora, espalhando-os pelo ar. Quando caem as chuvas, eles se misturam com as frutas Thewainada ${ }^{25} \mathrm{e}$ contaminam as águas, causando a proliferação da doença. Pajés poderosos podem fechar e abrir essas 'panelas', evitando ou provocando a doença. Nessa perspectiva, Kooname pode ser caracterizada como um tipo de Manhene. No passado, os pajés conseguiram fechar as 'panelas', de modo que a doença desapareceu; porém, os conflitos provocados pelo aparecimento dos brancos no cenário rionegrino suscitou sua reabertura por um pajé Tuyuca, como vingança pela morte de seu filho, assassinado pelos brancos; o episódio traz a origem do Kooname para o nicho das doenças derivadas das relações interétnicas.

O relato articula as principais variáveis correlatas ao fenômeno de produção de doença:

- sua eclosão está ligada a disputas e violência entre afins;

- longe de ser um evento individual, o episódio remete a relações travadas entre grupos sociais que lutam pelo controle do mundo;

- a sociedade humana, aqui representada pela família de Nhiãpirikoli, disputa posições com seres-espíritos da natureza, animais na forma, mas organizados em sociedades similares à dos Baniwa; são parte da alteridade para onde os Baniwa remetem a origem primordial da violência e do mal;

- o mito descreve as mudanças ecológicas que determinam os períodos de pique e de declínio da doença, as representando, no entanto, como parte do contexto das guerras entre afins; 
- finalmente, o relato acolhe as transformações geradas pelo aparecimento dos brancos no cenário no qual se origina e reproduz a doença, criando nexos explicativos que, articulando o pré e o pós-contato, explicam o incremento da mesma na região do Uaupés onde sua incidência, nos tempos atuais, é maior que nas terras baniwa (Abric, 1994).

Os mitos explicativos da patogênese também denunciam uma relação essencial dos personagens com a sexualidade transgressora, com a animalidade primordial contida a duras penas pela socialização humana, com o desregramento dos apetites e transgressões de toda ordem, das regras morais e sociais. A doença no mundo baniwa é uma forma de expiação de culpas e faltas, não apenas dos ancestrais, mas também daquelas cometidas pelos habitantes do mundo de hoje, a própria vítima ou seu grupo de parentes. Ela é simultaneamente uma categoria moral - é um dos meios de definição do comportamento socialmente desejável - e política assumindo uma forma de exercício de poder, através da qual se pode coagir, sem uso da força, os membros da sociedade a adotarem certos tipos de comportamento em detrimento de outros, contribuindo assim para a reprodução da visão nativa de mundo e para a manutenção do controle da vida social pelas gerações mais velhas.

Tais premissas são congruentes com uma das importantes funções da elaboração mítica: a função moral de delimitação do que é socialmente aceito e do que é reprovável; tais representações promovem a mediação entre extremos, apaziguam conflitos, instauram um ritmo domesticado a eventos perigosos como a doença (Lévi-Strauss, 1984). Assim, o cumprimento das regras de comportamento socialmente desejável aparece como uma das principais maneiras de preservar a ordem do cosmos, da sociedade e a sanidade corporal e espiritual.

\section{Doenças do cosmos}

Identificamos ainda um terceiro bloco de doenças geradas a partir da interveniência das estrelas no domínio humano. A primeira informação sobre esse grupo, denominado Hekoapi Ipoa, vem de Wright (2000), que utiliza a expressão "doenças do mundo ou do universo" para congregar agravos decorrentes de eventos climáticos e sazonais. Nossos dados de campo corroboram esta informação e mostram que essa categoria engloba um conjunto de sintomas gerados pela agressão de estrelas que se sucedem no céu, ao longo de diversos meses no ano. Assim, existiriam doenças causadas pela constelação Walipere, Kakodzode etc. A sintomatologia descrita pelos informantes é basicamente a mesma para todas, sendo caracterizada por vômitos, dores no corpo e febre; a doença seria um tipo de Walama, mas as flechinhas seriam atiradas pelas estrelas. 
A representação gráfica desse grupo de doenças pode ser feita assim:

Figura 4 - Doenças geradas com base na interveniência das estrelas no domínio humano

\section{HEEKOAPI IPOA}

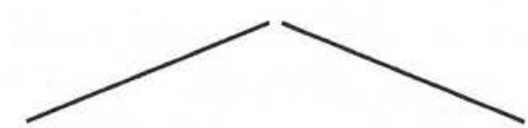

WALIPERI IPOANA

KAKODZODE IPOANA

Embora provocadas por seres cósmicos, elas também se relacionam com as intervenções dos pajés, que, quando poderosos, têm a capacidade de mobilizar os poderes de tais entidades, influenciando na sucessão das estações, na regulação do clima e maturação das frutas, eventos demarcados pela presença de constelações que se sucedem no firmamento. Elas também estão relacionadas ao cheiro das frutas maduras cujo ciclo de maturação é regulado pelos Yoopinai e assinalado pelo surgimento seqüencial de constelações no firmamento. As constelações são sibs ancestrais que foram transportados para o céu em um tempo remoto, mas ainda assim não são alheios aos assuntos humanos. De modo similar aos grupos de parentes aqui da Terra, elas interagem ativamente com sua contraparte humana: sentem ciúme, tomam partido nas disputas entre consangüíneos e afins, regulam o volume de água dos rios e igarapés - função explícita da constelação Kakodzude -, ordenam o clima etc. A hostilidade é uma das formas possíveis de interação; os astros podem flechar humanos, causando doença de tipo Walama, numa agressão que não é aleatória, mas segue seu aparecimento no céu; o auge da periculosidade de cada constelação coincide com seu ápice no firmamento, declinando conforme sua descida no céu. As doenças do cosmos também se ligam às relações entre afins, pois as estrelas são representadas como 'cunhados' agressivos.

As vítimas preferenciais das estrelas são os jovens e as mulheres, potencialmente mais capazes de negligenciar a higiene corporal, a obediência aos mais velhos, as normas de regulação dos casamentos preferenciais, a divisão de alimentos e a deferência devida aos co-residentes. Tais fatores, ligados ao descontrole dos impulsos, os tornariam mais susceptíveis ao ataque das estrelas.

A prevenção de tais agravos passa pela vigilância e controle estrito, pelos homens mais velhos, do comportamento dos jovens e das mulheres, particularmente no período de ápice da constelação agressora. As medidas preventivas 
compreendem, ainda, a exigência de que os jovens, particularmente do sexo masculino, se banhem à noite na água fria dos igarapés, antes do aparecimento da constelação no céu da madrugada, devendo enfrentar o sono e o frio, sem direito a aquecer-se ou secar-se. Na ocasião, os rapazes devem esfregar-se, particularmente no pênis, com um cipó que produz uma espuma. É um procedimento que visa à purificação, não apenas do corpo, mas também dos impulsos sexuais proibidos. 0 procedimento é visto como um meio de fortalecer e disciplinar o corpo e o espírito para resistir às potenciais flechadas das estrelas; é também recomendado para retardar as manifestações da senilidade. Trata-se, enfim, de uma estratégia disciplinar de gênero e de geração que incide sobre a domesticação do corpo. Muitas mudanças na sociedade baniwa, consideradas negativas pelos informantes, são atribuídas ao abandono dessas disciplinas corporais.

A explicação sobre a origem geral das doenças não deve ser pensada como algo estático. Ao contrário, os componentes do mundo mítico transmutam-se entre si, garantindo grande plasticidade aos relatos e personagens. Serpentes são simultaneamente peixes e humanos, além de representar também o homem branco. Os animais ancestrais podem ser aprendizes de pajé mal-sucedidos transformamse em Yoopinai, sibs se metamorfoseiam em estrelas etc. Igualmente, um tipo de doença pode se transmutar em outra sem descontinuidade lógica no relato. Quadros de Walama se confundem com doenças provocadas por Yoopinaie/ou pelas estrelas, não por uma confusão diagnóstica, mas por partilharem uma origem comum quando se constituíram os grupos de parentesco. Doenças aparentemente díspares se interligam numa rede de relações partilhadas e reproduzidas no mundo dos ancestrais e dos humanos.

\section{A Reprodução do evento patológico - o eixo horizontal do cosmos}

Saúde, doença e cuidados são estratégias situadas no plano de reprodução da vida social. Os humanos desenvolveram elementos de cultura, capazes de viabilizar o répasse de informações a seus descendentes e garantir a transmissão dos saberes acumulados a cada geração, independentemente das condições biológicas da reprodução. Os conhecimentos em questão envolvem a capacidade de estabelecer processos de classificação, codificação, registro e transmissão de informações sobre os fenômenos à sua volta, entre os quais os eventos de doença, que são remetidos diretamente às condições de produção da cultura na qual se processam (Samaja, 2000).

O eixo horizontal do cosmos baniwa trata da reprodução das relações de guerra, aliança, consangüinidade e afinidade entre grupos sociais humanos e destes 
com a natureza (Wright, 1996). Neste âmbito, a caça, a pesca, a roça, os casamentos, nascimentos, as trocas e as guerras são elementos de continuidade da vida social. De modo similar, situaremos a reprodução social da doença no eixo horizontal do cosmos baniwa, aplicando o modelo concêntrico de espaço social de Wright (no prelo) na análise da taxonomia deste grupo.

Nesse eixo, o processo patológico pode ser expresso por meio de um conjunto de círculos concêntricos, tal como concebido por Wright (no prelo), que enfatiza a reprodução socioespacial da doença através da movimentação dinâmica dos agressores e vítimas no interior e nas fronteiras sociais, geográficas e políticas da sociedade baniwa. A lógica subjacente a essa representação gráfica enfatiza o movimento 'centro' da cultura baniwa versus 'periferia', recorrente em vários relatos míticos.

Esse plano de análise remete para as relações de troca, alianças e disputas entre grupos de parentes e afins humanos, representadas no gráfico que apresentaremos a seguir pelo círculo mais interno, o das doenças que se reproduzem no interior das fronteiras da humanidade, por relações travadas entre os membros da sociedade baniwa ou por relações destes com outros povos indígenas rionegrinos; nesse plano situam-se doenças como Manhene e Hiwiathi; formas de agressões produzidas pelos homens na manutenção de sua vida social, ligando-se a vinganças, disputas, inveja e desentendimentos de todos os tipos.

Figura 5 - Circuito de reprodução das doenças

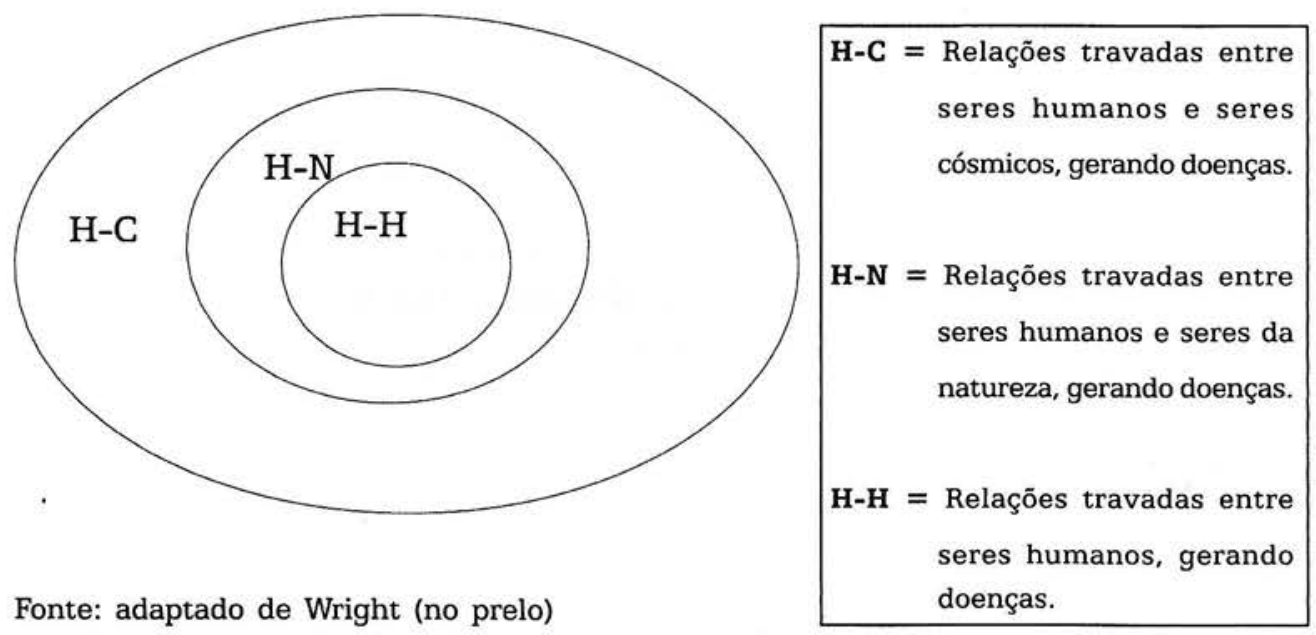

O círculo intermediário equivale às doenças surgidas no âmbito do contato e dos conflitos entre membros da sociedade humana e elementos de uma natureza transfigurada em sociedade pelo pensamento mítico. As doenças provocadas pelos Yoopinai, as picadas de cobra, infortúnios de diversos tipos e doenças decorrentes 
de transgressão das regras alimentares como Whiókali se situam nas interações conflituosas do lado 'de dentro' do mundo humano com o lado 'de fora', representado pela sociedade dos seres-espíritos, o espaço que os não-índios chamam de natureza. As doenças que se reproduzem neste âmbito recriam, atualizando-a, a luta ancestral entre homens e animais evidenciando a complementaridade destes dois pólos, nos quais os humanos se situam ora como predadores, ora como vítimas.

As restrições alimentares típicas dos momentos de liminaridade, particularmente os rituais pós-parto e pubertários, expressam essa tensão constante nos limites da sociedade humana. Tais momentos demonstram a ambígua condição do recém-nato e dos jovens púberes, membros parciais do grupo que podem facilmente ser capturados por uma alteridade selvagem. Em sua condição vulnerável, precisam de uma dieta especial e da proteção dos cânticos kalidzamai, que preservam o vínculo vertical que une o bebê e o/a jovem púbere à linha de ancestralidade.

Esses rituais também comportam um eixo horizontal, representado pela nomeação dos territórios ocupados pelos Baniwa, áreas socializadas e domesticadas da natureza agressiva, e dos peixes e animais capazes de garantir a subsistência dos membros da comunidade humana (Hill, 1989). Caso eles não sejam realizados ou tenham sido feitos incompleta ou erradamente, o indivíduo a quem se destinam - bem como seu grupo de consangüíneos - pode ser freqüentemente acometido pelas patologias que se situam nesse círculo de produção de doença. Mesmo os que cumpriram adequadamente os rituais de proteção podem ser acometidos por elas, caso estabeleçam relações de abuso e predação com os espíritos e elementos naturais não-domesticados que existem fora das fronteiras da sociedade humana.

O círculo mais externo do diagrama representa os conflitos potenciais estabelecidos entre seres humanos e cósmicos; ele remete à íntima interação que humanos, animais e espíritos partilhavam nos tempos ancestrais. Aqui se situam as Hekoapi Ipoa, o grupo especial de sopros Hiwiathi provocados pela invocação dos espíritos dos mortos Inyaime, bem como as doenças decorrentes de alterações climáticas e cósmicas desencadeadas por pajés poderosos. Esse círculo mais abrangente representa também a idéia de que todos os agravos ocorridos nos outros níveis estão contidos nesse circuito mais amplo da causalidade da doença; para os Baniwa todo evento patológico, longe de ser uma ocorrência individual, é um evento de âmbito simultaneamente social, sobrenatural e cósmico, ameaçando a estabilidade e a ordem deste e do "outro mundo" (Wright, 1996).

O grupo de doenças Walama ocupa uma posição especial nessa forma de representação gráfica, porque ele se refere simultaneamente aos três círculos. Podemos ter Walama como decorrência de conflitos entre humanos, situação em que a doença é mandada pelo pajé, e outro tipo provocado por flechas de Yoopinai e/ou das estrelas, ambos antigos humanos transfigurados em animais e astros. As doenças de branco devem ser situadas no círculo intermediário, já que ocupam 
uma posição fronteiriça, mas cuja origem se dá fora da cultura baniwa. Obviamente, nem toda interação social, com a natureza ou com o cosmos, é de ordem conflituosa e geradora de doença; apenas enfatizamos aqui este leque de possibilidades, dentre muitos outros.

Se efetuarmos uma junção dos planos vertical e horizontal de análise das categorias de doença baniwa, poderemos conceber uma representação gráfica como a que vemos a seguir:

Figura 6 - Planos vertical e horizontal de análise das categorias de doença baniwa

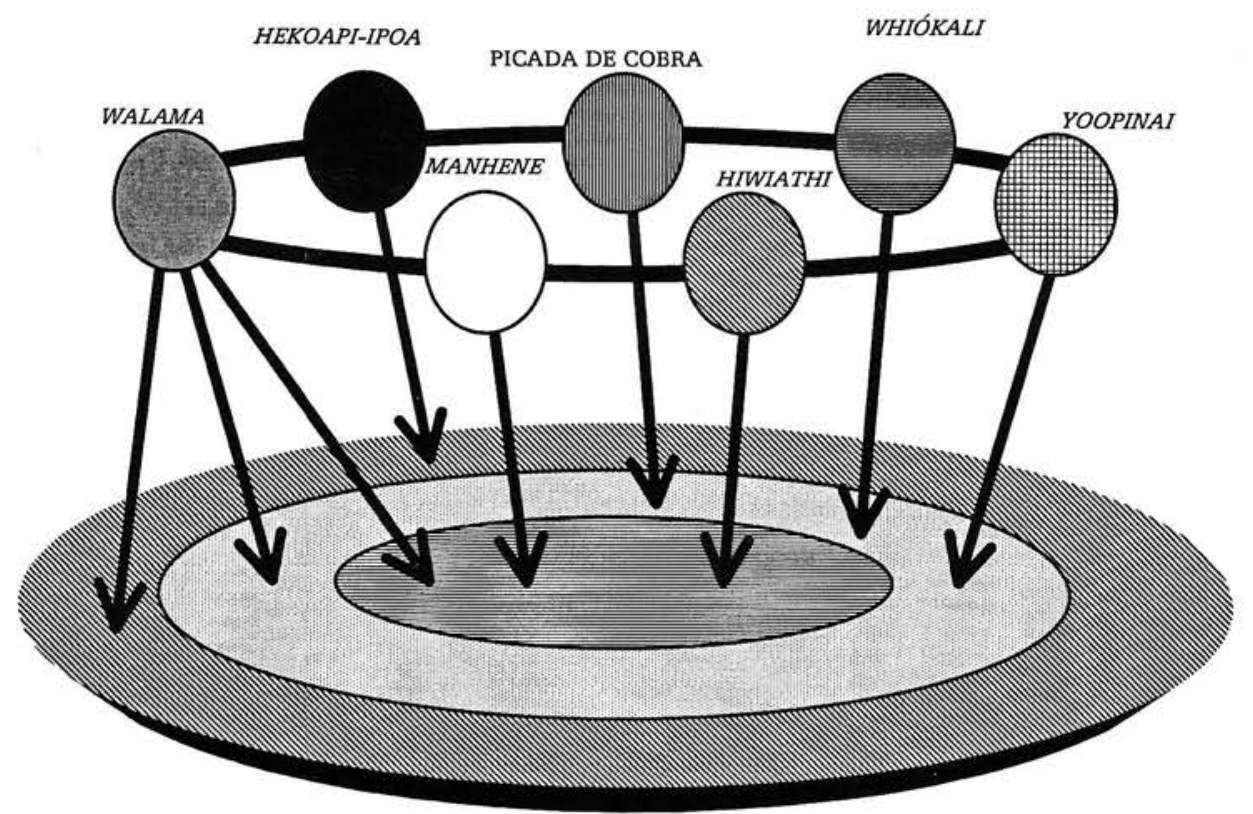

A identificação dos agentes imediatos da doença remete às interações sóciopolíticas conflituosas, seja entre os membros da comunidade humana, da natureza ou do cosmos socializados. Um afim, um enamorado ciumento, um amante desprezado, uma pessoa com inveja do sucesso do outro, um espírito da natureza com sua eterna belicosidade, a essência intrinsecamente perigosa e venenosa das mercadorias dos brancos, são todos elementos identificados nas relações de causalidade baniwa.

O reconhecimento do agressor pode se fazer através de sonhos, premonições, conversas entre os parentes da vítima ou, no caso dos evangélicos, do grupo de anciãos; pode comportar também a realização de sessões xamânicas 
quando o quadro não se resolve com outras condutas terapêuticas; a identificação, ${ }^{26}$ porém, não é essencial para a eficácia do tratamento. Plantas e rezas podem ser utilizadas com sucesso sem que se tenha uma identificação positiva de quem perpetrou a agressão/doença. O não-reconhecimento explícito do agressor é congruente com as restrições baniwa à expressão aberta de conflitos.

Nessa sociedade, o doente nunca é totalmente inocentado do que the acontece; a ocorrência de eventos patológicos costuma exigir uma participação da própria vítima. Comportamentos de egoísmo, avareza, preguiça, inveja, falta de controle dos próprios impulsos, curiosidade e sexualidade excessivas, desobediência às restriçọ̃es alimentares, às regras de higiene, às normas de obediência de gênero e de geração, são considerados pré-condições que favorecem o adoecimento; igualmente tais características de comportamento também tornam a pessoa suspeita de enviar Manhene ou Hiwiathi, quando ocorrem na aldeia. Tais atitudes contrastam com as valorizadas qualidades morais de diligência, obediência, controle dos próprios impulsos, firmeza de opiniões, higiene, generosidade, sobriedade e coragem de expressar suas próprias opiniões; todos esses são comportamentos que levam à boa saúde e/ou à capacidade de resistir às doenças.

A saúde é um estado alcançado pelo cumprimento das regras do bem viver; adoece quem descuida dos procedimentos de purificação, teve idéias ou sonhos libidinosos e não fez os rituais adequados para o caso; adoece-se ainda por manifestar curiosidade excessiva, ou por desejar lesar os outros com veneno. Mesmo quando se é vítima de um envenenamento ou de um sopro, a extensão do dano vái depender do grau de pureza e força espiritual para resistir à agressão. As crianças que sofrem de Whiókali por falta dos rituais capazes de amenizar seus efeitos não são responsáveis pelo seu estado, mas seus pais o são, na medida em que não cumpriram as regras de jejum pós-natal.

A causa última das doenças sempre remete às guerras, ao comportamento anti-social (incesto, assassinato, canibalismo, desrespeito dos mais jovens etc.) dos seres míticos ancestrais (Albert, 1988); são os atos de Nhiãpirikoli, Amaro, Kowai, Omáwali e outros personagens do panteão baniwa que condenaram o mundo de hoje à doença, ao infortúnio e ao caos. Os xamãs, os benzedores e os sujeitos comuns da cultura baniwa são continuamente chamados para manter a ordem do cosmos - e da sociedade - por meio de suas boas ações, da renúncia ao uso do veneno e do exercício do controle corporal, sexual e mental, em favor do bem comum. 
7 O autor alerta que o que ele está chamando de corpo não é a mera morfologia física do ser, mas "um conjunto de modos de ser que constituem um habitus ... o corpo (seria) um feixe de afecções e capacidades, que é a origem das (diferentes) perspectivas" (Viveiros de Castro, 1996:128).

8 Em termos baniwa, a noção de idade é também uma construção social, não se restringindo apenas aos aspectos biológicos da vida de uma pessoa; ela é relativa e condicionada à presença de consangüíneos mais velhos nos grupos de convivência e à capacidade de desempenhar papéis de responsabilidade na sociedade. Assim, por um lado um homem casado e com filhos pode ser considerado 'jovem' caso conviva com agnatos considerados mais velhos, seja no sentido biológico, seja por pertencerem a sibs considerados de 'irmãos mais velhos'. Por outro lado, entre os evangélicos podemos ter elementos cronologicamente jovens, mas considerados 'anciãos' pelo seu conhecimento privilegiado dos textos bíblicos. As categorias 'jovem' e 'velho' se referem à possibilidade de deter conhecimentos que propiciem o acesso a espaços de poder, prestígio e responsabilidade na sociedade.

9 A autora cita como exemplo o ritual do Jurupari, no qual a exclusão física das mulheres não esconde a apropriação de princípios e poderes femininos por homens que buscam a reprodução social do grupo - ao transformar meninos em membros plenos do grupo-por meios não-biológicos, já que estes são vistos como atributos da feminilidade.

10 Hill (1987) descreve a participação regular das mulheres no ritual Pudali, mas em sua descrição os cânticos e danças femininos são suplementares às performances masculinas que conduzem as encenações.

11 A firmeza de opinião é um atributo muito valorizado na sociedade baniwa; pessoas que mudam de idéia e de atitude são consideradas imaturas e inaptas a exercer funções de responsabilidade. As mulheres são representadas pelos homens como seres particularmente instáveis e irresponsáveis.

12 O cheiro deve ser considerado um demarcador entre a sociabilidade e a selvajaria, demandando elementos de cultura como a higiene, a defumação com plantas medicinais e tabaco para domesticá-lo, neutralizando sua periculosidade.

13 O termo 'dono de cânticos' (malikai-iminali) é usado aqui para designar um tipo de especialista religioso, que funda sua atuação no conhecimento de orações cantadas, ou 'rezas', como são chamadas pelos informantes. Esses cânticos são enunciados em momentos rituais importantes, como o pós-parto, o ritual de iniciação masculina, ritos de cura e outros eventos ligados aos ciclos produtivos da sociedade (Wright, 1996).

14 Wright (1993) estende as relações entre dano e umidade à origem da humanidade retirada dos buracos úmidos da cachoeira de Hipana, aos espíritos dos mortos que habitam mundos subaquáticos e às flautas Kowai, guardadas no fundo dos cursos d'água no intervalo entre os rituais pubertários, que são realizados no período chuvoso; a isso, acrescentaríamos também que o período chuvoso é o tempo de escassez de alimentos e da maior incidência de doenças. 
Conferências Evangélicas são grandes encontros religiosos que envolvem grupos fixos de aldeias geograficamente próximas e que parecem recobrir, entre os convertidos ao evangelismo, grande parte das funções outrora desempenhadas pelos rituais Pudali, estimulando as trocas cerimoniais e reafirmando alianças e solidariedades comunais. A este respeito ver Sampaio (2000).

16 Foi possível observar o uso intensivo desta alternativa no controle feito sobre as Organizações Indígenas. Nestas ocasiões, o discurso feminino, mobilizado na forma de fofoca, vem sendo utilizado para veicular o descontentamento e discordância de seus maridos com a atuação das lideranças das entidades. Em baniwa, o termo fofoca (kaitépe) tem a mesma raiz do verbo 'aconselhar' (kaíte), usado no sentido de evitar ou reduzir as transgressões, evidenciando uma função reguladora comum.

17 Este mito já foi analisado por Wright (1993/1994), numa perspectiva que remete às formas de reprodução social do mundo baniwa; estamos enfatizando os detalhes que são importantes para a análise das doenças. Hill (1989) encontrou entre seus informantes a associação simbólica entre Omáwali e as manifestações do desejo sexual excessivo e a destruição do mundo pela água. Os xamãs e outros especialistas podem utilizar esses poderes perigosos para domesticação de forças/espíritos da natureza e obtenção de alimentos para a subsistência humana.

18 Os Yoopinai são espíritos da mata, da água e do ar; são considerados 'donos' dos rios, dos animais e das florestas, sendo, por isso, agressores potenciais dos humanos que, para sobreviver, precisam predar esses recursos. Seus ataques aos humanos podem causar várias doenças.

19 Wright (no prelo) fez um estudo sobre o uso de Manhene, caracterizado por ele como uma forma de bruxaria. $\mathrm{O}$ autor assinala o caráter secreto de tais práticas, que refletiriam as disputas de poderes principalmente no âmbito da afinidade, pois existem interdições ao uso de veneno entre consangüíneos. Ele analisa casos concretos de atuação de envenenadores, demonstrando que essa forma de bruxaria pode recobrir conflitos interpessoais, intercomunais e interfrátricos, nos quais afins podem ser utilizados como instrumentos do envenenamento, uma forma de driblar a interdição à sua prática entre consangüíneos.

20 Outras categorias de doença contêm subgrupos mais homogêneos em relação ao substrato corporal onde se assentam: por exemplo, Whiókali congrega um conjunto de manifestações digestivas; Walama congrega manifestações agudas de tipo reumático; doenças causadas por Yoopinai agrupam doenças de pele etc. O grupo mais heterogêneo de manifestações é de fato o dos sopros Hiwiathi.

${ }^{21}$ Os informantes traduzem Dzeewhemipor tuberculose, mas não parece haver uma correspondência entre as manifestações dessa doença e o diagnóstico biomédico de tuberculose. As observações indicam que, sob o rótulo de Dzeewhemi, estão agrupados conjuntos de sintomas de doenças de evoluçăo crônica, que em termos biomédicos se traduzem em diagnósticos distintos.

22 O termo tem aqui um sentido distinto do usual no mundo do branco, onde o conceito de higiene se refere à prevenção de doenças microbianas através da assepsia dos corpos e de utensílios, visando à eliminação de microorganismos. Em termos baniwa, ele designa medidas materiais e simbólicas de proteção contra ataques de Yoopinai; as regras de higiene baniwa visam eliminar os cheiros das secreções corporais que atraem estes seres-espíritos. Nesse sentido, as regras de higiene têm como finalidade última o reforço das diferenças/fronteiras entre humanos e não-humanos. 
23 É importante não confundir 'passageiro' com 'transitório'; a tradução para o português do termo 'passageiro' busca enfatizar a capacidade que a doença tem de se transmitir entre as pessoas, isto é, seu caráter epidêmico. Os informantes são unânimes em afirmar, por exemplo, que existem diarréias que são "doenças de branco", como a diarréia de sangue (Iraithool), porque "passam" de uma pessoa para outra, enquanto manifestações diarréicas como Whiókali não têm esse caráter epidêmico, a doença "fica" numa só pessoa.

24 As principais patologias oriundas do contato, reconhecidas pelos informantes, são o sarampo (que não tem uma designação específica em baniwa), a gripe (Wheetsi), a diarréia de sangue (Iraithool), a varíola (Ibichikan) e a catapora (Karaka ibichikan = varíola pequena). São reconhecidas ainda a praga ou vela (macumba feita por feiticeiro branco ou Baré), a tuberculose e a malária (Kooname), que serão problematizadas em seguida.

${ }^{25}$ Essa fruta era predileta dos macacos Eenonai. Desejoso de eliminar estes seres para acabar com os venenos no mundo, Nhiâpirikoli envenenou-as, deixando-as para os macacos comerem; muitos deles morreram assim, mas seu chefe sobreviveu, garantindo a continuidade da existência do veneno. A maturação deste fruto coincide com o período de transição do inverno para o verão, época de recrudescimento da malária.

26 A identificação do agressor pode não ser essencial para a eficácia do tratamento, mas a relação entre diagnóstico e tratamento é de dependência e coerência mútuas. Ao contrário de algumas tendências apontadas na literatura - ver, por exemplo, o estudo de Sindzingre (1981) sobre os Senoufo-, entre os baniwa a decisão terapêutica é estritamente dependente do tipo de diagnóstico formulado, que pode ser mudado em caso de fracasso da terapêutica adotada; neste caso, o tratamento também mudará. Ambos constituem, portanto, uma realidade indissociável. 
Cuidados com a saúde devem ser considerados mediadores, simultaneamente materiais e simbólicos, que permitem aos grupos sociais representar subjetivamente, eventos ameaçadores à manutenção da vida, contra os quais deve intervir. De modo geral, eles costumam reforçar as esferas de regulação e reprodução da ordem social estabelecida e buscam produzir medidas destinadas a atenuar ambigüidades que se exacerbam no caso de doença, e a eliminar ou evitar o fato anômalo gerado pela eclosão do evento patológico (Samaja, 2000).

No mundo baniwa, os procedimentos preventivos e curativos se imbricam de tal forma que não podem ser considerados entidades discretas; rezas, jejuns, procedimentos de higiene, uso de plantas medicinais e curas xamânicas prestamse simultaneamente às duas atividades.

O leque desses cuidados compreende os cânticos kalidzamai, as recitações iapakethi, a restrição sexual, a dietética, as plantas medicinais, as curas xamânicas e os medicamentos industrializados. Neste texto nos limitaremos a efetuar uma síntese de plantas medicinais, dietas e regras de higiene, remetendo o leitor que deseje maiores informações sobre a cura xamânica e sobre os kalidzamai e os iapakethi para publicações de Wright (1993, 1996), Hill (1989); e aquele que deseje se informar sobre o uso de medicamentos industrializados, para Garnelo \& Wright (2001).

O itinerário terapêutico seguido pelo doente e sua família não difere do que é registrado com freqüência na literatura (Sindzingre, 1984), (Langdon, 1994). Ante um evento patológico, eles formulam uma hipótese diagnóstica baseada no acervo de saberes preexistentes sobre o tema, decidindo também a opção terapêutica que pode passar inclusive pelo uso de medicamentos industrializados. O xamã só costuma ser acionado caso o evento patológico persista ou se apresente com especial gravidade. Dentre as variáveis que limitam a intervenção do xamã, apontamos a escassez desse especialista, o alto preço de seu trabalho e as grandes distâncias que o doente deve percorrer até encontrar um xamã que possa tratá-lo. Além disso, o pequeno número de xamãs faz com que atualmente apenas a fratria Hohodene disponha desse especialista, o que torna o recurso a ele potencialmente perigoso para um doente das outras fratrias. 
Caso o tratamento escolhido não proporcione resultados satisfatórios, a doença poderá ser reclassificada sob novo diagnóstico, com conseqüente redimensionamento das alternativas terapêuticas. Observamos que mesmo doenças corriqueiras costumam ser interpretadas à luz das interações políticas e conflituosas estabelecidas entre os humanos ou entre estes e os seres-espíritos da natureza; qualquer sinal de doença já é indicativo de um potencial distúrbio no cosmos, exigindo uma ação terapêutica imediata. As atuações xamânicas visam principalmente aos problemas de ordem cósmica, mas os donos de cânticos podem intervir também nos conflitos sociopolíticos implicados na eclosão do processo patogênico.

Os diagnósticos de doença são objeto de discussão cotidiana nas aldeias; quando alguém adoece, as pessoas opinam sobre os diagnósticos possíveis, voltando suas atenções particularmente para a possibilidade de que seja um caso de Manhene, seguramente o evento patológico mais angustiante para os Baniwa e, segundo sua percepção, também o mais freqüente. Mais do que qualquer outra doença, a ocorrência de um caso de Manhene representa sempre uma ameaça coletiva, um sinal agudo de distúrbios cósmicos e políticos que ameaçam a ordem do mundo.

Sonhos, augúrios e premonições do doente ou de seus co-residentes costumam ser observados com atenção porque contribuem tanto para o diagnóstico quanto para o prognóstico da evolução do caso. Via de regra, o adoecimento por Manhene é parte do circuito de vinganças por agressões recíprocas em função de eventos de gravidade variável, indo desde discussões banais, no entanto, levadas a extremos por desafetos inconformados, até sua forma mais extremada, o xamanismo de vingança, no qual se pagam os serviços de um pajé para exterminar o agressor ou assassino de um parente.

O contato com substâncias perigosas como o cheiro dos peixes gera Whiókali. A penetração dos venenos de Kowai ou de serpentes geram o Manhene, e o cheiro do combustível e da fumaça traz a doença do branco. Todas essas são formas de contágio simbólico, cujo alcance deve ser controlado por severos procedimentos de purificação ritual, para isolar o perigo e obter a renovação cósmica que garante a abundância, a fertilidade e a continuidade das gerações humanas. Se por um lado os procedimentos rituais têm por objetivo evitar a difusão do estado de impureza, por outro eles são medidas de proteção para os já envolvidos pela violência ancestral que ameaça não só a eles, mas toda a descendência humana. É nesse âmbito que situamos o uso das plantas medicinais e a dietética e as regras de purificação baniwa.

A preservação da saúde depende do exercício da moralidade e da solidariedade nas relações sociais, do reforço das relações intercomunitárias, do autocontrole e da limitação de todo comportamento excessivo, da limpeza dos corpos, dos espíritos e dos utensílios domésticos e controle das ações predatórias 
sobre a natureza. Os processos terapêuticos têm por meta afastar o ser do doente da putrefação e do comportamento socialmente descontrolado, reconduzindo-o aos limites da sociedade humana, rompendo um contato perigosamente próximo com a alteridade e contribuindo para a restauração da ordem cósmica. Eles reproduzem criativamente os princípios contidos nos ciclos míticos de KowailDzooli nos quais os fundamentos da domesticação da natureza e da socialização da pessoa baniwa foram estabelecidos. As curas xamânicas, que se processam pela viagem do xamã a pontos diversos do plano vertical do cosmos reforçam a idéia de sua conexão originária com esse nível de causalidade.

\section{Uso de plantas medicinais}

As plantas medicinais cultivadas e selvagens compõem um extenso conjunto de saberes disseminados em todos os níveis da sociedade baniwa. Existe um vigoroso processo de circulação de plantas cultivadas que, tal como a mandioca, acompanham o circuito de troca de esposas. Quando a mulher se casa, seus pais a presenteiam com um estoque de plantas que podem proteger sua futura família de males diversos e que, na prática, reforçará o acervo disponível na aldeia do esposo. O marido também pode receber plantas de seus consangüíneos, e o casal zela pelos recursos que lhes são disponibilizados, recorrendo, sempre que necessário, aos ascendentes e outros familiares em busca de novos espécimes.

A divisão sexual de trabalho vigente na sociedade se reproduz também no manejo das plantas medicinais. Existe um amplo conhecimento sobre plantas cultivadas partilhado entre homens e mulheres, sem que se negue a existência de certos nichos de diferenciação, pois os homens costumam conhecer e manejar melhor as plantas propiciatórias ao sucesso na caça e na pesca, e as mulheres reservam para si próprias o conhecimento de plantas destinadas a tratar as doenças da feminilidade, as quais guardam secretamente nas roças. Tais diferenças recobrem tensões nas relações de gênero, nas quais homens e mulheres procuram resguardar seus campos de saber, utilizando-os como reforço das suas próprias posições no meio social.

Os saberes sobre plantas medicinais silvestres constituem um monopólio masculino. Os homens costumam identificá-las na mata durante as expedições de caça ou nas idas para a roça. Os lugares de sua ocorrência são mentalmente mapeados para que possam ser encontrados em caso de necessidade. A variação na distribuição dessas informações é dependente da disponibilidade das espécies e das características do ecossistema nas proximidades das aldeias. $O$ interesse individual em ampliar seu acervo de conhecimentos também é muito importante, pois os Baniwa valorizam a iniciativa pessoal, deixando grande parte do aprendizado 
a cargo do empenho e dedicação dos aprendizes; o ensino-aprendizado do uso de plantas medicinais não envolve qualquer restrição dietética ou sexual por parte dos envolvidos. A interrupção dos rituais masculinos de passagem vem ameaçando uma reprodução sistemática e consistente de tais conhecimentos, pois ele se caracterizava como um espaço de consolidação e ampliação das informações produzidas na socialização primária em âmbito doméstico.

Apesar da tendência apontada na literatura sobre o uso de plantas medicinais como um recurso que atua meramente no tratamento dos sintomas, no caso baniwa existem espécies capazes de atuar em níveis mais profundos de causalidade, pois, se existem plantas para tratar sintomas gerais como dores, febre, fraqueza e palidez, a maioria delas é usada para tratar as doenças reconhecidas na taxonomia baniwa. Elas não atuam apenas como sintomáticas - quem desempenha esse papel são os medicamentos industrializados, largamente consumidos para tratar os sintomas, ainda vagos, das primeiras manifestações de doença -, mas têm indicações próprias para cada tipo de doença, existindo plantas para tratar tipos específicos de Manhene, Hiwiathi, Thooli etc. Sua origem mítica talvez possa explicar essa singularidade, pois, nas representações dos informantes, plantas e rezas são recursos terapêuticos equivalentes, criados num mesmo gesto por Dzooli no tratamento instituído para evitar a morte de Mawirikoli.

As plantas são bastante disseminadas em todas as aldeias, e são indicadas amplamente não só para o tratamento das doenças conhecidas, mas também para a alteração de comportamentos çonsiderados socialmente inadequados. Assim, também existem plantas para combater a preguiça, para aumentar a valentia e a disposição para o trabalho, para acalmar crianças choronas, para aprender a língua portuguesa etc. Como dito anteriormente, o uso de plantas medicinais não é um recurso restrito apenas ao tratamento do evento patológico; trata-se de mais um componente num conjunto de cuidados que visam auxiliar pessoas a retomar o desempenho dos papéis que lhes são socialmente designados na vida cotidiana na aldeia.

\section{Dietética}

A dietética baniwa é um importante componente dos cuidados que objetivam à preservação e à recuperação da saúde. Na verdade, não se concebe qualquer tratamento sem a adoção concomitante das dietas. Exceto para o uso de medicamentos industrializados, todos os outros procedimentos de cura exigem a adoção deste coadjuvante terapêutico. Além disso, situações de liminaridade, como o pós-parto, a puberdade, rituais de iniciação masculina e feminina e o treinamento xamânico, exigem uma rigorosa restrição dos alimentos. Ela se aplica, ainda, a outras situações da vida: é adotada quando enamorados desejam seduzir parceiros 
através de procedimentos mágicos, como o uso das plantas de Monotsi, e quando os homens desejam obter sucesso na caça. A adoção de restrições alimentares subentende a restrição concomitante da atividade sexual, compreendida como um elemento inerente à própria dieta. Tais procedimentos se perpetuam ao longo das diversas fases da vida, incorporando-se às formas próprias do viver baniwa.

Sendo a natureza concebida como análoga à sociedade humana, as fontes de alimentos são também representadas como dotadas de características perceptivosensoriais que permitem definir sua condição de maior ou menor periculosidade potencial para os seres humanos. Dessa forma, os alimentos podem ser compatíveis/ incompatíveis com um estado de doença, fortes, fracos, agressivos, inofensivos, agonistas, neutros ou antagonistas de um estado de doença e poluição corporal. A análise dos alimentos interditados mostra que, no âmbito do registro mítico, a comida considerada perigosa para o consumo humano em situações de liminaridade se origina de inimigos de Nhiápirikoli, como Kowai, os macacos Eenonaie os peixes/serpentes.

Os kalidzamai, rituais que representam a principal forma de prevenção de doenças, também orientam a dietética e as regras de higiene que o indivíduo deve seguir por toda a vida. Eles são realizados nos rituais de nascimento e de iniciação pubertária. Entre os evangélicos, os termos da recitação variam, comportando trechos das orações cristãs enunciadas nos cultos, sendo as referências ao xamanismo cuidadosamente expurgadas; porém os princípios dietéticos são seguidos à risca, talvez até de forma mais rigorosa que entre os católicos.

O sistema de reclusão utilizado para os pais e recém-nascidos, jovens púberes, doentes de Manhene e picados de cobra segue a lógica da purificação ritual adotada na primeira morte. Os que a ele se submetem são proibidos de manter atividade sexual, comer caça, peixes com pimenta, sobretudo se o peixe for de dente e de esporão. $O$ contato com as pessoas em geral é restringido, tendo o objetivo de evitar particularmente o contato com mulheres menstruadas, grávidas e com pessoas que possam ter mantido relações sexuais recentemente, pois, nessas condições, elas podem exalar cheiros que agravarão a doença. Mulheres grávidas e menstruadas são particularmente perigosas porque o sangue relacionado à sua condição ${ }^{27}$ é considerado uma importante via de enfraquecimento dos reclusos. Tais restrições visam limitar os agravos que poderiam precipitar o recluso na mesma morte de Mawirikoli.

As dietas recomendadas para pessoas doentes podem variar segundo o diagnóstico, mas os dados coletados indicam algumas regras gerais, a saber:

Para doentes de Manhene e picados de cobra, a dieta é bastante rigorosa no início do tratamento, sendo proibida a ingestão de proteína animal (carne ou peixe), tanto pelo doente, quanto pelos consangüíneos; a esposa ou o marido de quem foi picado estão, em tese, liberados da dieta, mas, como a mulher não caça e nem pesca e o marido não cozinha, em termos práticos a restrição acaba se 
impondo, em maior ou menor grau ao cônjuge. Nos primeiros dias, o doente só pode comer mingau de farinha em pequena quantidade, fracionado ao longo do dia; se o tratamento se mostrar efetivo, pode começar a ingerir peixes pequenos, desde que sejam apanhados com rede e que não tenham ferrão, esporão, dentes ou gordura, o que obviamente restringe bastante o tipo de alimento a eles disponibilizados. De acordo com o tipo de Manhene, particularmente os quadros crônicos, esta proibição pode se estender por vários meses, enquanto durar o tratamento.

O uso de pimenta é igualmente proibido, pois esses doentes estão, em ambos os casos, envenenados, e o veneno é o oposto simétrico da pimenta. $\mathrm{O}$ condimento que tempera o alimento é análogo ao veneno que tempera o corpo humano, tornando-o apetitoso para os espíritos canibais. Como, em geral, toda carne e peixe costumam ser ingeridos com pimenta, a proibição de seu uso reforça a restrição à ingestão de carne ou peixe pelos doentes. Essa periculosidade se perpetuou no mundo a partir do primeiro ritual de passagem, quando a quebra do jejum pelos iniciandos impediu a despoluição da pimenta e dos alimentos, que permaneceram como fonte constante de perigo para os seres humanos.

Picados de cobra são proibidos de comer também qualquer tipo de alimento vegetal que tenha leite que possa ser extravasado, pois extravasamento similar poderia ocorrer do líquido retido no membro picado; igualmente, não podem tomar banho, pois o contato com a água poderia exercer tanto um efeito de extravasamento (hemorragia) quanto de enchimento (edema) no local da picada. Essa é a mesma lógica que proíbe o contato do picado com mulher grávida e mulheres menstruadas, pois o sangue presente em ambas poderia provocar sangramento ou inchaço no doente. Uma dieta igual a do picado de cobra é recomendada para a mulher (e seu marido) que sofre de hemorragia após o parto, reforçando a idéia de continuidade entre ambas situações.

Existem algumas especificidades ligadas ao tipo de Manhene que acomete o doente: nos casos de Manhene originado de pêlo de Kowai, há uma proibição mais forte de comer animal de pêlo; os envenenados por Omai Panattemi, um veneno vegetal feito da chamada folha de piranha, não podem comer frutas que provoquem coceira nas mucosas, como o abacaxi e alguns tipos de cará, pois a coceira se reproduziria no intestino, aumentando o sangramento provocado pelo veneno. Por igual razão, estão proibidos de comer peixes com dentes e ferrões, particularmente a piranha. ${ }^{28}$ Doentes de Manhene cuja origem é o cérebro de Kowai também são proibidos de comer partes da cabeça de qualquer animal aquático ou terrestre; nos casos em que esse tipo de veneno provoca distúrbio de conduta, no qual o doente assume comportamento de macaco (Manhene puuekhaime), de pássaro (Manhene hipiralikhaime) ou de um ser aquático (Maṇhene kachirikhaime), há uma proibição mais forte em torno da ingestão do animal equivalente ao distúrbio de comportamento do doente. 
Manhene e picadas de cobra são condições especiais que transportam o doente para uma posição fronteiriça entre a humanidade e animalidade; seu corpo é o palco da luta entre esses dois pólos e sua alma enfraquecida se presta mais facilmente a ser tomada por um espírito animal. Nesse contexto as dietas buscam uma purificação ritual capaz de demarcar uma separação radical entre esses dois domínios que se confundem perigosamente no evento patológico.

Para os doentes de Whiókali, a dieta varia segundo a origem: se for Whiókali de caça, o doente está proibido de comer qualquer animal de pêlo. A proibição se estende às frutas e tubérculos com pêlos, como manga, inhame, cana etc. Se a origem de Whiókali for de peixe, o doente é proibido de ingerir peixes que apresentem aspecto que lembre as cobras (peixes lisos, sem escamas), peixes com dentes, ferrões, esporões e com muita gordura, considerados potencialmente capazes de ferir o intestino do doente, enfraquecendo-o, fazendo-o sangrar e agravando seu quadro, pois, à medida que o doente enfraquece, o peixe/serpente em seu intestino se torna forte. Eles são ainda proibidos de comer frutas que tenham espinho, como cana, ${ }^{29}$ pupunha e cubiu, frutas gordurosas ou ainda as longas, que lembrem serpentes, como a fruta conhecida por ingá.

A proibição de peixes gordurosos ou de aspecto similar ao das $\operatorname{cobras}^{30}$ parece se prender a uma idéia de reforço simbólico: a doença Whiókali remete à luta ancestral entre proto-humanos comandados por Nhiâpirikoli e a serpente ancestral Omáwali, que representa os animais aquáticos, principal fonte de alimento do povo baniwa; sua eclosão é uma atualização cotidiana de um conflito que nunca cessou. O 'pitiú' do peixe mal-cozido possibilita o crescimento de um peixe/serpente no intestino do doente, que retira forças do conjunto das serpentes e peixes em geral, particularmente aqueles mais perigosos ou agressivos, justamente os que são mais proibidos para este tipo de doente. Além disso, quanto mais parecido com uma cobra, maior potencial teria o peixe ingerido de fortalecer o peixe/cobra no intestino do doente.

A pouca restrição ao consumo de peixes pequenos poderia ser considerada estranha se os imaginarmos como membros do grande conjunto de animais aquáticos. Entretanto, em seu estudo sobre a taxonomia baniwa, Hill (1988) demonstra que os peixes pequenos, os primeiros a serem ingeridos com a melhoria dos quadros de doença, pertencem a nichos classificatórios diferentes daqueles ocupados pelas cobras e pelos peixes grandes com dentes, ferrões, ou de aspecto semelhante ao das serpentes. Segundo os critérios taxonômicos baniwa, tais peixinhos pertencem, dentro do mundo aquático, a um domínio distinto daquele dos peixes/serpentes canibais, do qual Omáwali deve ser considerado a representação prototípica.

Feridas na pele, atribuídas em geral à ação dos Yoopinai, geram a proibição de alimentos considerados 'feridos', ou seja, frutas ou tubérculos com a casca 
rompida, furada ou enegrecida. Bananas, frutas de rápida putrefação, são proibidas para pessoas com lesões de pele ou de órgãos internos, pois poderiam acelerar ainda mais a evolução desfavorável.

O cheiro do alimento apodrecido é indicativo da capacidade agressora dos seres-espíritos da natureza. O cheiro, uma parte que representa o todo, é capaz de gerar o processo mórbido, mesmo que não haja um agente animal visível no alimento. Parasitas encontrados em frutas concretizam esta idéia, levando à associação da doença à putrefação, atual ou potencial, dos alimentos; a goiaba, por exemplo, é considerada uma fruta de alto grau de patogenicidade, dada a freqüência com que já contém 'vermes' em si mesma, mesmo sem estar putrefata.

O uso de sal está proibido em todos os casos de doença em que ocorra edema, sangramento digestivo, coceira e ferimentos na pele, pois o sal é considerado um alimento cáustico, passível de provocar abrasões nas mucosas e pele, além de ser responsabilizado pelo inchaço de quaisquer lesões existentes. Além disso, o sal é produto da alteridade perigosa do branco. Para os Baniwa, sua fabricação - como a de qualquer mercadoria industrializada - envolve a participação de combustível e a produção de calor, elementos que se incorporam ao produto, multiplicando sua periculosidade.

A utilização de plantas medicinais indica sempre a necessidade de restrição alimentar concomitante; de modo geral, pudemos observar que esta regra é mais severa entre os sibs baniwa e mais amena entre os de falar curipaco, residentes no Brasil. Cada tratamento tem dietas específicas, ligadas mais ao tipo de doença do que à planta em si. Também aqui as restrições dietéticas se estendem ao grupo de consangüíneos do doente, particularmente os que são co-residentes. Segundo os informantes, este seria um dos motivos que leva as pessoas, quando podem optar, a preferir os medicamentos industrializados, cujo uso não exige a adoção das severas dietas; desta forma, elas estariam poupando o resto da família do sofrimento e privações inerentes aos tratamentos com plantas medicinais.

O tipo de alimento permitido varia segundo o tipo de doença. Frutas doces e alimentos 'frios' podem ser importantes coadjuvantes na dietética terapêutica. No plano simbólico eles são evocados nos cânticos e nos mitos, nos quais as categorias 'frio' e 'doce' são evocadas como parte da reparação da alma e do corpo lesados pelos seres agressivos.

As dietas gozam de uma rigorosa coerência interna, demonstrando as íntimas e fortes ligações entre os incidentes da vida cotidiana e os fundamentos míticos que regulam a vida social. Além de recriar diariamente a luta ancestral com a alteridade disruptiva, elas incrementam o ascetismo, o autocontrole e a disciplina corporal, qualidades consideradas vitais à preservação do bem-estar e da harmonia na vida comunal. 


\section{Regras de purificação e de higiene corporal}

Os Baniwa dispõem de diversas formas de purificar o corpo e o espírito, que variam segundo as finalidades de quem as utiliza e cujo grau de severidade também varia pelas mesmas razões; o uso delas no treinamento de um xamã envolve minúcias e um rigor infinitamente mais acurado que sua utilização por um não-especialista.

Busca-se a purificação do espírito através da contenção dos impulsos, do controle cuidadoso de pensamentos e sonhos libidinosos, dos sentimentos de raiva, das explosões de cólera, da tristeza, frustração, cobiça, inveja e do desejo pelas mulheres proibidas. Existe uma forte interdição social à manifestação pública destes sentimentos, que remetem ao caos primordial; sua ocorrência é interpretada como uma forma de manifestação patológica (sickness), que demanda a mortificação do corpo pelo jejum, pelas privações sexual e sensorial (particularmente no caso dos reclusos) e pela exposição às intempéries. Tais estratégias se destinam particularmente aos jovens, pessoas em estados diversos de liminaridade, caçadores, xamãs e donos de cânticos, ou seja, aqueles em situações de maior risco de transgressão a normas socialmente valorizadas. O jejum é uma forma de aprimorar o comportamento humano, reaproximando-o do domínio da cultura.

Os membros do grupo considerados incapazes de viabilizar um controle pleno de seus impulsos sofrem restrições à ocupação de posições de poder político e podem se tornar suspeitos de ministrar veneno ou enviar sopros aos seus desafetos. Quem cultiva rancor e ódio, que podem redundar em condutas agressivas contra outros membros da coletividade, deve esperar que em algum momento ocorra um retorno, uma retribuição à sua agressividade, o que poderá ocorrer na forma de doença ou infortúnios diversos, ostracismo social, ou vingança xamânica de suas vítimas. Tais condutas costumam ser vigiadas pelos outros membros do grupo, pois suas conseqüências (Likoada) podem atingir não apenas o transgressor, mas qualquer um, dada a crença numa continuidade entre o todo social e cada um de seus membros.

A saúde e o bem-estar passam pelo cultivo da alegria, da gentileza com os consangüíneos, da boa vontade com as falhas das mulheres e crianças, e principalmente pela honestidade e generosidade redistributiva dos bens adquiridos. A riqueza material é uma prova contundente da transgressão das regras da reciprocidade. A acumulação e apropriação individual de riquezas podem transformar o acumulador em alvo da maledicência, da inveja, do veneno e dos sopros, que serão o troco de sua avareza. A representação da doença é parte das estratégias de controle da individualização dos membros do grupo e expressa a tensão permanente entre interesses e necessidades individuais e coletivos; prevenção e cura são reafirmações da solidariedade e da coesão social. 
A purificação do corpo, com suas repercussões sobre o espírito, passa pelas regras de higiene corporal que se imbricam com as conflitivas tensões entre seres humanos e animais-espíritos como os Yoopinai. As principais regras de higiene praticadas pelos Baniwa são os banhos, que devem ser tomados ao acordar, após a relação sexual, antes do preparo das refeições (mulheres), quando a pessoa estiver suada e fundamentalmente antes de se alimentar. As mãos devem ser escrupulosamente lavadas após a manipulação de peixe ou caça e depois das refeições, com vistas a eliminar quaisquer vestígios do cheiro do animal e evitar Whiókali. Mulheres menstruadas e no pós-parto não devem preparar alimentos nem trabalhar na roça, e seus odores corporais devem ser expurgados, não apenas com banho, mas também com a utilização de plantas medicinais próprias para afastar os Yoopinai.

Os banhos são imperativos quando a pessoa viaja de um rio para o outro, pois as famílias de Yoopinai são diferentes em cada rio e costumam atacar os estranhos com ferocidade. As normas de higiene também se estendem aos utensílios de cozinha e de pesca que têm de ser limpos até que todo o cheiro do peixe ou da caça desapareça; as vasilhas com alimento devem ser cobertas; objetos pessoais e utensílios domésticos devem ser cuidadosamente guardados preferencialmente no interior das casas, para que se mantenham a salvo da ação dos Yoopinai e dos envenenadores.

Como a diligência e a operosidade são associadas à saúde, e a preguiça, a sujeira e o mau cheiro são ligados à doença e à maldade, a busca incessante de limpeza se estende às casas e à aldeia, cabendo aos chefes de família, particularmente ao capitão, zelar para que as medidas de higiene do ambiente sejam mantidas e os moradores preservados de ações maléficas.

Além de classificar, nomear ou ordenar a realidade, essas representações e práticas buscam viabilizar também uma intervenção prática sobre os corpos, a alimentação, os meios de subsistência, as relações de gênero, de geração e de afinidade. Elas intentam estabelecer consensos que são constantemente ameaçados pelas tensões inerentes ao viver. A ritualização da cura propicia um prolongamento dos consensos e um apaziguamento momentâneo dos conflitos que inevitavelmente se atualizarão no próximo episódio de doença.

Os cuidados de saúde aqui descritos remetem às funções ética e normalizadora dos saberes sobre doença e cura; se não fossem internalizados como parte essencial da existência, poderiam ser facilmente ignoradas pelos membros do grupo, o que é evitado pela crença de que o abandono ameaçaria a própria sobrevivência da humanidade. A ocorrência de um evento patológico ajuda a materializar tais regulações, reforça os laços de coexistência comunal e o controle das manifestações do interesse individual. Trata-se de um tipo de poder simbólico com a capacidade de impor uma cosmovisão que gera conseqüências concretas na realidade social, transportando o mundo do pensamento para o mundo do corpo e transformando representações mentais em relações sociais (Abric, 1997). 
Em seu clássico estudo sobre o tema, Mary Douglas (1976) demonstrou que os sentidos atribuídos à desordem, à sujeira e à poluição costumam representar somente uma pequena parte do comportamento socialmente aprovado e se prestam principalmente a tentativas de solucionar conflitos gerados em situações moralmente ambíguas. Para ela, controles simbólicos deste tipo costumam ser produzidos com mais freqüência em sociedades nas quais existe uma escassez de alternativas eficazes para limitar os comportamentos desviantes de seus membros. Sua produção tanto expressaria pressões políticas e sociais através das quais membros de uma sociedade tentam influenciar o comportamento dos outros, quanto conteúdos simbólicos mais amplos nos quais se delineiam visões gerais sobre a ordem social e o cosmos. O plano concreto refletiria idéias de simetria ou de hierarquia aplicáveis ao sistema social mais amplo, ligando instituições sociais à ordem cósmica. Sujeira e desordem seriam subprodutos das tentativas de ordenação e classificação das coisas; purificação, separação, ordenação e punição de transgressões visam impor sistematizações em realidades vivenciadas como desordenadas e proteger a unidade política e cultural do grupo que as produz.

Os dados analisados ao longo dessa discussão mostram que, no mundo baniwa, esta correlação entre a vida cotidiana e o plano sociocósmico é algo plenamente reconhecido, quase corriqueiro. A violência e o caos ancestrais, caracterizados como simbólicos por um observador externo, não apenas são percebidos como reais, mas se atualizam quotidianamente em manifestações como o Manhene, compelindo os membros da cultura a crer na eficácia dessas produções simbólicas e a atuar segundo as regras e elas subjacentes; impressas física e mentalmente nos vários momentos da vida, elas levam as pessoas a atuar no pressuposto de sua inevitabilidade. A falibilidade deste pressuposto é reiterada pela eclosão de novos episódios de doença, revelando uma funcionalidade mais ideal do que real; mas é inegável que tais estratégias contribuem para contornar, apaziguar ou suprimir a violência transgressora que se expressa no evento patológico e para reinstalar periodicamente a unidade sociopolítica do grupo.

27 Para os Baniwa as grávidas e menstruadas partilham a condição de portar sangue em seu abdômen; considera-se que a barriga da grávida está cheia de sangue destinado a alimentar a criança e que é extravasado quando ela nasce. Nove meses de sangue represado tornam a mãe e a criança bastante impuras, vulneráveis, portanto, a qualquer forma de ataque mágico.

28 A piranha é considerada a materialização dos espíritos aquáticos canibais. 
29 $O$ que é denominado espinhos em relação a esta fruta, são na verdade os duros fragmentos da palha e da casca de cana que podem ferir uma pessoa.

30 Os peixes ditos lisos (sem escamas) são todos considerados muito gordurosos pelos Baniwa, de forma que estas duas características se superpõem e se reforçam mutuamente. 
o a posteriori da doença

Os quadros nosológicos até aqui descritos constituem o que Sindzingre (1981) chama de categorias a priori, ou seja, informações pré-disponibilizadas na cultura do grupo que orientam as pessoas sobre os sentidos do evento, as escolhas diagnósticas e terapêuticas para fazer frente ao problema. Entretanto as normas culturais não são um bloco fechado de prescrições obrigatórias a serem literalmente seguidas pelos sujeitos. Elas oferecem um conjunto de orientações gerais, do qual as pessoas podem lançar mão em seus problemas habituais, recriando-as e aplicando-as de forma criativa segundo as contingências do dia-a-dia (Sahlins, 1997a). Em razão disso, vamos analisar relações potencialmente conflituosas e alguns eventos de doença para tentar apreender como estas representações sociais se expressam na vida cotidiana.

Os 17 mitos, coletados na pesquisa, que explicam a origem das doenças falam do desejo de poder (busca de Malikal), disputas entre afins e consangüíneos pelos objetos de poder, disputa por mulheres, cobiça, adultério, assassinato, canibalismo, gula, uso irresponsável do poder mágico, curiosidade irrefreada, fúria, sexualidade descontrolada, roubo, vingança, dissimulação, mentiras, desobediência a regras de conduta estabelecidas pelas gerações mais velhas, disputas entre homens e mulheres, preguiça, sujeira, crueldade e inveja, dentre outros comportamentos considerados socialmente reprováveis na visão baniwa de mundo.

Cabe, então, perguntar: como as prescrições míticas se expressam na vida concreta das pessoas? De que forma elas dão conta destes eventos cuja eclosão se propõem'a limitar? Quais são os grupos que se conflagram na sociedade baniwa? A que interesses essas representações de doença servem? Com que finalidade são usadas? Em busca de responder a questões como estas, rastreamos casos de doença efetivamente ocorridos, para tentar apreender como orientações gerais da cultura se expressam na vida cotidiana das pessoas.

A observação participante nas aldeias confirmou que, no plano concreto, se reproduzem os pontos mais importantes de tensão e conflito já apontados nos relatos míticos; estas relações conflituosas se atualizam no contexto de contato interétnico, assumindo novas configurações, assentadas ainda sobre os antigos pólos 
de disputa. É o que podemos observar, por exemplo, na relação entre gerações mais velhas e mais jovens; essas, exprimem pontos de tensão e conflito que seguramente precedem o contato interétnico. Diversos mitos demonstram os conflitos estabelecidos entre gerações, sendo um dos mais violentos o que envolve o próprio Nhiâpirikoli, que se esforça por controlar seu filho Kowai, lançando mão de recursos como o exílio e o assassinato. Outros falam de pais que disputam os favores sexuais das esposas de seus filhos, como no caso do mito de Kaali thayr, de relações guerreiras conduzidas contra seus afins por Nhiãpirikoli, que se apóia no potencial agressivo de seus irmãos mais jovens (por ele controlado) para sustentar tais conflitos, externos ao grupo de consangüinidade (Journet, 1995).

A análise de relações políticas nas aldeias permite observar os confrontos entre irmãos ou primos 'mais velhos' e 'mais novos'31 que podem atravessar gerações, como se verá mais adiante, no caso de doença, $n^{2} 1$. Tais linhas de tensão são mais antigas que as relações de contato interétnico, mas este favorece perceptivelmente a atualização cotidiana de atitudes rebeldes (reais ou potenciais) de jovens desejosos de se autonomizar do controle dos mais velhos, de fazer valer os saberes/poderes do mundo do branco, transformando-os em meios de obtenção de prestígio ou privilégios que atenuem a assimetria perante os mais velhos.

A situação encontrada no campo mostra que as gerações mais velhas exercem um controle efetivo sobre os mais jovens, mas este controle é instável e sujeito a contestação, sendo possível observar, apesar dele, rebeldias, bem ou malsucedidas, contra as regras de casamento, as definições paternas do papel a ser desempenhando pelo jovem na vida política da(s) aldeia(s), dietas pós-natais, regras de disciplina corporal etc. Os mais velhos expressam abertamente seu desconforto diante das atitudes dos mais jovens, situando-as num quadro geral de afrouxamento dos costumes que contribui para acelerar a disseminação do veneno, a entropia e a desorganização potencial do cosmos, comprometendo a sobrevivência da sociedade baniwa. As novas gerações se rebelam contra os duros procedimentos disciplinares, o que se revela, por exemplo, na flagrante redução do número de pessoas interessadas em cumprir o rígido aprendizado xamânico.

Igualmente as relações travadas por homens e mulheres expressam fortes tensões que surgem, tanto nas narrativas míticas, quanto na interação cotidiana de gêneros nas aldeias, comparecendo como uma das principais vias de eclosão da doença e da morte.

Se nos relatos míticos as mulheres parecem estar sempre prontas para 'escorregar' para o domínio da alteridade, como acontece à mulher de Nhiãpirikoli com seu filho-serpente, na vida cotidiana na aldeia a situação não parece ser muito diferente. $O$ contato das mulheres, principalmente as jovens, com elementos da fronteira cultural são limitados e controlados por suas famílias: diversos procedimentos são utilizados para evitar seu contato como os brancos, com os 
Yoopinai e com as serpentes. Os procedimentos dos kalidzamai feitos por ocasião da primeira menstruação têm, entre seus objetivos, domar a sensualidade feminina e anular potenciais relações sexuais entre mulheres e serpentes, seres que representam a sexualidade sem freios e que ameaçam a reprodução da sociedade humana. Os cantores nomeiam os limites do território baniwa, definindo procedimentos específicos de proteção à mulher e delimitando as fronteiras da cultura, na qual ela pode transitar em segurança (Hill, 1988). As secreções corporais femininas são cuidadosamente evitadas, seus odores devem ser eliminados e suas atividades culinárias reguladas de forma a evitar a poluição perigosa e adoecedora.

As relações entre evangélicos e católicos já foram exploradas por Journet (1995), Wright \& Hill (1986) e Wright (1998) e serão melhor desenvolvidas no capítulo seguinte. No momento, basta assinalar que é um dos importantes pontos de conflitos e disputas potencialmente geradores de doença, o que, com grande freqüência, encobre as disputas entre afins, particularmente quando as situamos na geopolítica das relações Içana e Aiari.

Relações entre lideranças de aldeia (capitães) também são conflituosas e envolvem a busca de prestígio entre os seus liderados e a disputa de bens e serviços obtidos com sociedade nacional, gerando, não raro, acusações de uso de veneno, sopro ou malefícios diversos. Como é de se esperar, conflitos deste nível se superpõem às tensões entre afins e consangüíneos, pois os sujeitos envolvidos em tais querelas ocupam obrigatoriamente uma posição nesses nichos.

Os contatos com outros grupos étnicos, representantes de uma alteridade agressiva, também podem gerar a eclosão de eventos patológicos. Da mesma forma, as relações com seres-espíritos da natureza e do cosmos representam igualmente uma alteridade perigosa, que estabelece relações de reciprocidade negativa.

Existem diversas formas de preservar o equilíbrio das relações de controle de uns grupos sobre outros, utilizadas pelos que ocupam posições de poder dentro da sociedade; Entre elas podemos citar as conferências evangélicas, as representações e práticas de doença e cura e a vigilância que os capitães exercem sobre os jovens, particularmente os que recebem a delegação de responsabilidades 'modernas', como o trabalho de agente de saúde e de líder de Organização Indígena. O controle·do comportamento dos jovens é uma preocupação tão premente nesta sociedade, que diversas medidas vêm sendo tomadas historicamente pelos mais velhos para implementá-lo; dentre estas, poderíamos citar a conversão ao evangelismo, que, para Journet (1995), representa uma forma de retorno às exigências morais e às rigorosas condutas que outrora se concretizavam nos rituais de iniciação masculina e que, hoje, se atualizariam nos cultos e conferências.

Tentando responder a essas questões, levantamos informações sobre algumas situações que talvez possam elucidar as dúvidas que acabamos de expressar. Com vistas a proteger os informantes, os nomes das pessoas envolvidas 
nos casos levantados foram trocados porque algumas das disputas que envolveram estas pessoas estão mais vivas do que nunca e representam uma permanente ameaça de tragédia e morte.

O VENENO COMO INSTRUMENTO DE EXPRESSĀO DE DISPUTA PELO PODER POLÍTICO ENTRE CHEFIAS DE ALDEIA; UMA DISCÓRDIA QUE ATRAVESSA TRÊS GERAÇŌES

O caso estudado parte de um fato ocorrido há mais de dez anos: a morte, atribuída a envenenamento, do filho mais velho de uma família de sib Dzawenai. Ainda que não houvesse uma acusação pública, a pessoa responsabilizada pela morte foi um tio patrilateral, irmão classificatório de seu pai. Os elementos que antecedem o drama remontam a 30 anos antes e foram resumidamente os seguintes:

Primeira versão (contada a partir da ótica de Joaquim e de sua família)

A família em questão residia em uma só aldeia; no início dos conflitos havia as seguintes famílias residindo na comunidade:

- Família A: Joaquim, sua esposa e seus quatro filhos e seu pai, Arilton;

- Família B: Manduca, sua esposa e seis filhos, seu pai, Severino e sua mãe, Joana;

- Família C: Matilde, viúva, e dois filhos.

Joaquim, Manduca e Matilde são primos paralelos; Arilton, o pai de Joaquim, era o capitão da comunidade, mas estava velho, prestes a se afastar do cargo. Severino, o pai de Manduca, sempre desejou ser capitão, mas nunca conseguiu ocupar o lugar, alegadamente por ser mais novo que o irmão capitão. $O$ velho capitão decide se afastar e, em vez de atender o desejo do irmáo, decide passar o cargo para seu filho mais velho, Joaquim, que o sucede. Explode uma onda de conflitos cotidianos, que se exacerbam quando acontecem festas na aldeia $e$ os homens ingerem bebida alcóolica. Os conflitos nunca são assumidos como decorrência da disputa pelo cargo de capitão e algum tempo depois se transfiguram em conversão religiosa; Severino e seus filhos convertem-se ao evangelismo e passam a hostilizar Arilton e Joaquim, que permaneceram católicos. No fundo a disputa girava não apenas em torno do cargo de capitão, mas também do desejo de bens e prestígio oriundos da missão católica, que tinha nessa comunidade um de seus principais pontos de apoio na disputa com os evangélicos da Missão Novas Tribos. Não conseguindo estabelecer uma aliança sólida com os padres, Severino opta por se tornar crente, convertendo também sua família.

Os anos passam e a situação parece se acomodar um pouco. Três anos após a sucessão, o pai de Joaquim cai gravemente doente, a suspeita é de envenenamento; ele passa vários dias entre a vida e a morte, até que Joaquim se encoraja em usar um potente contraveneno, que pode matar o doente caso haja qualquer erro em sua preparação. $O$ envenenado reage bem ao tratamento, 
sobrevive, se recupera e acusa veladamente o irmão de tê-lo envenenado. A acusação é grave, principalmente por envolver consangüíneos. A convivência se torna impossível e o grupo familiar se fraciona: Joaquim e sua família permanecem na comunidade de origem, e Severino, Manduca, esposa e filhos fundam uma nova comunidade em local antes usado por todos para fazer roça. Desgostosa com o problema, Matilde se muda com os filhos crescidos para São Gabriel.

Na nova comunidade, Severino finalmente torna-se capitão, embora já esteja bem velho. Quando ele morre, seu filho Manduca assume a chefia do povoado. As relações entre as duas aldeias permanecem tensas por vários anos, mas, aos poucos, as pessoas vão se reaproximando, passando a freqüentar eventos em comum. A conversão evangélica se reverte e as pessoas da nova comunidade voltam ao catolicismo. Joaquim e sua família não deixam de fazer comentários mordazes sobre essa instabilidade de crença religiosa. Joaquim coloca os filhos para estudar na escola da missão e seu segundo filho torna-se professor; ele mostra-se também um promissor aprendiz de rezas que o pai lhe ensina com gosto. $\mathrm{O}$ filho de Joaquim funda uma escola na comunidade, reconhecida pela Secretaria de Educação. Manduca tenta, sem sucesso, fazer o mesmo em sua aldeia; além de não ter filhos com a escolaridade necessária para ocupar o cargo de professor, a existência de uma escolinha credenciada bem perto de sua aldeia faz com que a Secretaria de Educação rejeite seu pedido; os filhos e netos de Manduca devem se dirigir à aldeia de Joaquim e estudar lá. Assim é feito, mas a hostilidade volta a explodir e o clima permanece tenso.

Quase um ano depois, o professor adoece e morre subitamente com uma forte dor abdominal; sua família atribui a causa de sua morte à disputa pelo cargo de professor. Não há uma acusação explícita, mas todos murmuram que Manduca, ou alguém a seu mando, seria o envenenador. À família de Joaquim cabe aceitar a perda do filho; este passa a investir então na educação dos netos, filhos de seu filho mais velho, visando reabrir futuramente a escola.

Essa história foi reconstituída a partir dos depoimentos dos atores sociais envolvidos neste drama que dura quase 30 anos. No momento da pesquisa encontramos a seguinte situação:

Um neto de Joaquim é professor na escola, que recebe também as crianças da comunidade de Manduca. Ambas as famílias desejam ter um agente de saúde, pois não foram contempladas com o recrutamento anterior de agentes comunitários de saúde. A partir de sua atuação no Projeto de Medicina Tradicional Baniwa, o filho mais velho de Joaquim consegue uma vaga. Manduca, que até então não se interessara pelo assunto, encaminha seu filho mais novo para o trabalho com plantas medicinais. $O$ filho de Manduca entra em uma competição franca com o filho de Joaquim tentando fazer uma horta de plantas medicinais melhor e mais variada que a de seu primo. Quando o 
filho de Joaquim consegue um contrato de agente comunitário na Prefeitura, Manduca também tenta obter, sem sucesso, uma vaga para o filho.

Repete-se o que ocorreu na escola anos antes: os técnicos da Secretaria de Saúde consideram dispensável lotar dois agentes de saúde em comunidades tão próximas e tão pequenas; recomendam que o filho de Joaquim estenda a cobertura de suas açóes até a aldeia chefiada por seu tio. Ele tenta, vai de canoa até lá uma vez por semana para fazer atendimento e educação em saúde. Suas tentativas são rechaçadas pela família do tio, que acusa o novo agente de saúde de sonegar remédios e de ganhar dinheiro à custa dos parentes. Depois de alguns meses alguém coloca sal no motor rabeta que move a canoa do filho de Joaquim, estragando a máquina. Depois desse incidente, ele deixa de ir à comunidade do tio. A alegação pública é de que não pode ir porque não tem mais motor para se deslocar; em privado, ele admite seu medo de ser envenenado como o irmão.

A Secretaria de Saúde recebe a denúncia de que o agente comunitário não estaria cumprindo suas obrigaçóes de visitar a aldeia vizinha, onde vive a família de seu tio; a denúncia é atribuída a uma tentativa de fazê-lo perder o cargo e liberar a vaga. Ele recebe uma notificação da Secretaria de Saúde: deve comparecer a São Gabriel para explicar por que não cumpre as obrigações de cobertura da comunidade do tio, que fica na sua área de abrangência. $O$ agente se recusa a ir, pois não quer explicar que teme ser envenenado por seus próprios familiares.

O problema se agrava e gera uma intervenção da diretoria da Organização Indígena que cobre essa região. Os dirigentes tentam mediar o conflito, amenizar o teor das acusaçóes e conseguir uma alternativa geradora de renda para o filho de Manduca, que desejava o cargo do primo. Não há uma soluçấo para o caso. Até nossa última viagem a campo, o agente tinha conseguido engendrar uma explicação plausível para os técnicos da Secretaria de Saúde, mas continuava sem atender a aldeia de seus parentes. Manduca continuava pressionando a Organização Indígena para conseguir um emprego para o seu filho, e Joaquim e sua família viviam praticamente reclusos em sua aldeia, receosos de comparecer a eventos públicos, nos quais se exporiam à ação de envenenadores. A sangrenta disputa que dura quase 30 anos não parece ter qualquer perspectiva de término.

Segunda Versão (síntese dos pontos principais, a partir da ótica de Manduca e sua família):

$O$ motivo do desentendimento entre Arilton e Severino seriam as constantes bebedeiras de Arilton e seus filhos, gerando distúrbios na comunidade. Buscando limitar a hostilidade, Severino teria procurado a conversão evangélica, tentando manter seus filhos longe da violência e do alcoolismo. A correção do comportamento da família de Severino teria enfurecido Arilton, que tratou de 
expulsá-los da comunidade. Severino e seus filhos teriam sido obrigados, então, a procurar outro lugar para morar.

Quanto à acusação do envenenamento de Arilton, Manduca afirma que, se houve veneno, foi por causa do envolvimento do primeiro com feiticeiros, pois ele treinava para ser pajé e se relacionava com pessoas más. A interpretação dada para a morte do filho mais velho de Joaquim é similar: segundo Manduca, ele só queria ser da cidade, estudava na missão e se achava mais importante do que as outras pessoas; pode ter sido envenenado ou mesmo soprado pelas pessoas com quem costumava beber. A obtenção da escola e do cargo de agente de saúde por Joaquim é interpretada como fruto de suas relações servis com os missionários católicos, com os quais buscaria beneficios em detrimento do direito das outras pessoas. Para Manduca, o filho de Joaquim roubou a vaga de agente de saúde que deveria pertencer ao seu filho, com apoio das lideranças da Organização de Base; por esta razâo, ele pressiona a diretoria da entidade para resolver o problema criado por sua intervenção.

Este exemplo trata de disputas entre agnatos, envolvendo doenças, mortes e acusações de uso de Manhene, numa flagrante contradição com a ideologia vigente, que remete tais agressões para a alteridade. Aqui o uso (suposto) do veneno está ligado à disputas por bens, prestígio e pelo controle político de uma aldeia e das relações de aliança com os missionários brancos. Ao longo do tempo, as mesmas disputas vão assumindo outras configurações/pretextos/razões que são continuamente atualizadas e reordenadas em torno de novas instituições produzidas no espaço interétnico, como a escola, o assalariamento e as atividades da Organização Indígena. As razões atribuídas ao envenenamento partilham um campo explicativo comum; para ambos os contendores, as causas do ocorrido remetem à transgressão de regras morais: o lado de Joaquim atribui a seqüência de desgraças à inveja e à ganância de Manduca; para este, os motivos seriam a soberba, a avareza e a recusa da distribuição dos cargos. O conflito de interpretações caracteriza um mercado simbólico no qual os discursos concorrentes expressam posições e os atores negociam poder e sentidos explicativos dos episódios de doença, tentando fazer valer a sua interpretação como a mais fidedigna e-legitimadora da posição política que tentam consolidar (Verón, 1980). O Manhene aparece como forma de controle da diferenciação social, da individualização e da acumulação de poder simbólico e material.

A conversão religiosa nos primeiros anos e a militância no movimento indígena nos momentos posteriores surgem como munição numa guerra de acusações e contra-acusações que antecede o aparecimento destas instituições na vida comunal. 

DE SAÚDE

Primeira Versão (contada a partir da ótica de Leandro):

Leandro começou a apresentar tosse com catarro, fraqueza, palidez e emagrecimento; passou sete meses com estes sintomas, que se agravaram paulatinamente. O primeiro diagnóstico, feito pela família, foi de envenenamento. Leandro, um bom conhecedor de plantas medicinais, fez uso de várias delas, sem obter qualquer melhora; o irmão o tratou com os remédios disponíveis na farmácia do posto comunitário de saúde da aldeia, também sem resultado. Embora não estivesse melhorando, ele não procurou um pajé por ser evangélico; em compensação comparecia a todas as Conferências que eram organizadas em sua área e nelas orava fervorosamente, tentando obter a cura para sua doença.

$O$ quadro foi se agravando e um dia o doente teve uma crise de vômito com sangue vivo; depois disso foi removido para a Casa do Índio de São Gabriel, onde permaneceu por mais de três meses sem que se obtivesse um diagnóstico para sua doença; foi encaminhado para a Casa do Índio de Manaus e, após quatro meses de permanência, recebeu diagnóstico de tuberculose. Foi tratado durante seis meses, recebendo alta como curado. Leandro voltou para casa, mas continuou se sentindo doente: tinha ondas de calor noturno, fraqueza, sonhava freqüentemente com mortos e não conseguia trabalhar normalmente. Continuou tomando remédios feitos de plantas medicinais para tratar o veneno que acreditava permanecer em seu corpo. Por vezes, tinha que interromper o tratamento porque nem ele, nem seus familiares suportavam as rigorosas dietas. Ao longo do tempo em que buscou tratamento com plantas, chegou a acumular em sua roça mais de 32 plantas para tratar Manhene $e$ Hiwiathi. Ele as obtinha através de troca ou de pagamento em dinheiro e as utilizava regularmente. Não havendo solução satisfatória do problema, tentava outra planta e assim sucessivamente; esgotou primeiramente todo o estoque de recursos que the foi acessível para o tratamento de Manhene e depois para sopro, até que finalmente rendeu-se à impossibilidade de se auto-curar e, apesar de seu ato conflitar com sua fé evangélica, decidiu procurar um pajé.

$O$ informante relembra que, durante esse período, sua família enfrentou dolorosas privações, tanto pela restrição alimentar decorrente das dietas, quanto por sua incapacidade em prover a caça e o peixe diários. Além disso, a compra de combustível, plantas e outros remédios e os sucessivos deslocamentos em busca de tratamento fizeram com que ele exaurisse toda a reserva de dinheiro do grupo familiar, acumulada no tempo do garimpo.

Leandro passou dois anos e meio doente e, mesmo tratado para tuberculose, só se sentiu curado ao se tratar com um pajé Hohodene em São Gabriel. Com o pajé, também ficou sabendo que sua doença não era decorrente de 
envenenamento e sim de um sopro, que havia sido feito por um membro do sib walipere dakenai de outra aldeia, com quem teve uma discussão logo após o término de uma Conferência Evangélica, mais ou menos um ano antes de adoecer. A discussão decorreu de uma discordância quanto à indicação de pessoas para ocupar o cargo de ancião na comunidade vizinha.

Segunda Versão (contada a partir dos desafetos de Leandro):

A pessoa a quem Leandro atribui o sopro que o acometeu situa-se como um dentre seus muitos desafetos ${ }^{32}$ na região onde ele vive, partilhando eventos sociais com evangélicos e católicos no mesmo trecho de rio. Com eles, não foi possível discutir diretamente a acusação feita por Leandro, mas sua doença foi comentada por diversas pessoas que mantêm uma relação conflituosa com o mesmo. Essas pessoas vêem Leandro como alguém difícil, com um comportamento autoritário - sempre tentando definir o que os outros devem fazer - e ganancioso - sempre tentando obter vantagens à custa de outras pessoas que exercem liderança política nas aldeias vizinhas. ${ }^{33} O$ episódio de conflito a que Leandro atribui o sopro que o vitimou é confirmado, mas as pessoas o interpretam como tendo sido fruto da tentativa de Leandro impor quase à força a indicação de um cunhado seu para o cargo de ancião, em troca de algumas vantagens negociadas com o pretendente, o qual, segundo esses informantes, não tinha as qualidades requeridas para o exercício do cargo. Informantes católicos também não vêem Leandro com bons olhos; acreditam que ele seja um conhecedor de venenos, uma pessoa perigosa, de quem se deve ficar longe; além disso, teria o hábito de perseguir e difamar os benzedores católicos do Aiari. Os católicos não deixam de observar, com mordacidade, que tais condutas não o impediram de procurar um pajé quando se viu seriamente doente. Os entrevistados atribuem uma conotação muito negativa a este tipo de atitude contraditória.

De modo geral, os desafetos de Leandro consideram muito difícil saber quem possa tê-lo envenenado ou soprado, pois muita gente poderia ter feito algo assim. Consideram como possibilidade alternativa que ele seja vítima de suas próprias práticas de uso de veneno.

A doença de Leandro também tem como pano de fundo as disputas políticas, desta vez travadas entre afins, gerando um rico cenário de versões e contraversões dos sentidos de doença, cuja eclosão estaria ligada ao mau uso de Malikai, materializado na manipulação de venenos que terminam por se voltar contra ele próprio (Likoada); o doente, por sua vez, atribui seus problemas à inveja da prosperidade de sua aldeia.

Ele percorre todo o itinerário terapêutico disponibilizado por sua cultura e pelas instituições não-indígenas; apesar disso, o diagnóstico biomédico de 
tuberculose se subalterniza à taxonomia indígena, onde finalmente obtém uma adequada interpretação e subseqüente resolução para o seu problema. Os sucessivos fracassos terapêuticos promovem também uma relativização da conversão religiosa, o que não passa despercebido aos inimigos de Leandro. O último ponto relevante do relato são os prejuízos materiais e simbólicos gerados pela adoção do "papel social de doente", que o impossibilita de cumprir as obrigações inerentes à sua condição de chefe de família e de aldeia.

Caso 3:

UMA MĀE 'ESTRAGADA' PELO SOPRO

A pesquisadora, que também é médica, percorre comunidades para fazer gravação com informantes do Manual de Doenças Tradicionais. Ao pernoitar em uma das aldeias do Aiari, o agente de saúde pede que a mesma avalie três crianças que estão doentes na comunidade; duas delas têm casos simples de diarréia e gripe, mas a terceira criança, de aproximadamente quatro meses de idade, apresenta um quadro grave de desnutrição e desidratação e corre sério risco de morte. Não é possível, num primeiro momento, detectar a causa da desnutrição. A pesquisadora decide interromper a viagem e buscar atendimento hospitalar para o doente; conversa com a família sobre a necessidade de remoção para São Gabriel, os pais se mostram relutantes, mas por fim concordam em levar o filho para a cidade. A remoģão se deu sem agravo significativo do quadro, que começou a melhorar ainda em viagem, com uso intensivo de soro de reidratação oral. Durante a viagem, a pesquisadora pôde obter mais detalhes sobre a doença: por onde o grupo passava, as pessoas apontavam para a mãe, dizendo que a mesma estava estragada por um sopro, e por isso seu leite não sustentava o bebê. $O$ pai e a mãe concordavam com o diagnóstico e informaram que tentaram o uso de várias plantas medicinais para tratar o sopro, sem resultado; apesar de serem evangélicos, tentaram os serviços de um benzedor, igualmente sem uma solução satisfatória.

A origem do sopro foi atribuída à vingança de um antigo pretendente da mãe da criança, que foi rejeitado pela família dela; este mesmo ex-pretendente teve uma altercação com o marido da mulher estragada, graças a problemas de conversão religiosa. Na aldeia onde moram, metade das pessoas é evangélica e a outra metade é católica. Houve uma eleição para capitão, na qual o pai da criança doente e o ex-pretendente de sua esposa concorreram ao cargo. $O$ pai da criança ganhou a eleição, tornando-se capitão; o outro concorrente, ressentido, teria mandado fazer um sopro para estragar o leite da mãe, procurando assim causar a morte do filho do casal.

Em todos os lugares por onde o grupo passava, as pessoas facilmente diagnosticavam o problema como sendo um tipo de sopro chamado de kettalimi, mas o diagnóstico era sempre acompanhado de uma acusação mais ou menos explícita à mãe, a quem atribuíam a maior parte da responsabilidade pelo que 
ocorrera. As humilhações à mãe se sucederam ao longo de todo trajeto, até São Gabriel; sua condição de 'estragada' representava um estigma ${ }^{34}$ que diminuía sua credibilidade junto às outras mulheres e provocava rejeição à convivência com a mesma.

Em São Gabriel a criança foi internada no hospital e se recuperou plenamente da desnutrição; o diagnóstico biomédico revelou que a desnutrição se deveu à insuficiência da quantidade de leite materno disponível para aleitá-la, sem que houvesse qualquer outra causa orgânica associada. No hospital, foi instituído aleitamento artificial, que a mãe usou por mais ou menos dois meses, substituindo depois o leite artificial pelas comidas disponíveis na aldeia.

O caso da mulher estragada traz os já conhecidos confrontos políticos entre homens, mas agora matizados pelas disputas por mulheres. O relato não se refere diretamente à disputa entre os gêneros, mas sim à periculosidade inerente à condição feminina, que a torna sujeito e objeto dos problemas que enfrenta. Não é desprezível a participação da mulher na geração do evento patológico; se no início do relato ela aparece como uma vítima, o comportamento subseqüente de homens e mulheres é uma demonstração eloqüente da sua culpa pela falta de alimento para o filho.

DOENÇA TRADICIONAL ACOMETE AGENTE DE SAÚDE

Marivaldo é um agente de saúde curipako que tem certo grau de desentendimento com seu pai, a quem considera como uma pessoa ignorante das coisas do mundo do branco. Marivaldo se orgulha de ter freqüentado a escola, de seu treino como agente de saúde, do conhecimento de medicamentos industrializados e de saber operar a radiofonia. Quando o projeto de Medicina Tradicional foi iniciado, ele foi um dos agentes de saúde que pouco se interessou pelo tema, apesar do grande conhecimento de sua mãe sobre uso de plantas medicinais.

Quando nasceu seu primeiro filho, a família insistiu para que Marivaldo seguisse as dietas e os procedimentos de purificação correlatos ao evento. Ele, porém, não cumpriu as regras, preferindo viajar para assistir a uma Conferência Evangélica. Meses depois começou a sentir fraqueza, falta de apetite, indisposição para o trabalho, dor de cabeça, insônia e pesadelos recorrentes nos poucos momentos em que conseguia dormir. $O$ caso foi diagnosticado como uma doença de Yoopinai, decorrente do não-cumprimento das restriçôes pós-natais. $O$ agente de saúde passou vários meses doente, incapaz de cumprir as funçóes inerentes ao seu trabalho com saúde. Foi tratado, pela mãe, com plantas medicinais, melhorando lentamente, mas sem um retorno completo ao seu estado de saúde anterior.

O caso de Marivaldo ficou conhecido em todo o Içana, foi divulgado pela radiofonia por seu pai, como um exemplo da desobediência dos jovens. 
A doença de Marivaldo aclara outra faceta dos sentidos de doença, a do controle de gerações. $O$ ponto de partida é a recusa do jovem em aceitar as regras de comportamento impostas pelas gerações mais velhas, demonstrando, por um lado, as dificuldades destas em garantir seu cumprimento, e, por outro, a existência de espaços de contestação, reforçados pelo manejo de saberes e artefatos do mundo do branco. O pai aproveita a eclosão dos sintomas para reafirmar sua autoridade, normalizar e reenquadrar os comportamentos do filho rebelde; os sintomas se tornam reforço do poder paterno, habilitando-o a "fazer ver e fazer crer" nas interpretações tradicionais de doença; o uso da radiofonia, símbolo dos saberes que subvertem o poder dos mais velhos, curiosamente permite uma inversão do equilíbrio de forças em favor dos mais velhos.

\section{ENVEnEnamento de Mariano}

Mariano é um hohodene de aproximadamente 40 anos, que vive na aldeia do sogro no Rio Içana. É benzedor e no início da pesquisa era também capitão de sua comunidade; o sogro lhe havia repassado o cargo, como uma estratégia para garantir sua permanência na aldeia, pois ele tencionava mudar-se de volta para o Aiari. Essa decisão, porém, gerou tensões entre seus cunhados, que desejavam suceder o pai na chefia. Pouco depois de iniciarmos a pesquisa, Mariano ficou doente: apresentava distúrbio de comportamento caracterizado por inquietude, um discurso que oscilava entre a coerência normal do dia-a-dia e longas falas desconexas em que citava trechos de rezas de modo ininteligível; emagreceu muitos quilos e em pouco tempo adquiriu uma aparência bem mais velha que a da sua idade cronológica. Também já não conseguia cumprir suas obrigações como chefe de família e como capitão. Ia para São Gabriel e não retornava, ficava vagando na cidade, passava fome e se embebedava com freqüência.

Não raro sua família também passava fome, pois ele pouco pescava e seus filhos mais velhos estavam estudando e trabalhando fora da comunidade. Igualmente a aldeia ficou suja, seus prédios deteriorados, os trabalhos comunitários não eram mais realizados e com freqüência a refeição comunitária consistia apenas em chibé. O padre ameaçava não mais rezar missas na comunidade por falta de condições de alojamento, pois a Igreja estava desabando. Mariano conta que foi envenenado por uns Tukano do Uaupés. Relata que foi convidado para beber uma cerveja com eles e não prestou atenção que era servido de uma garrafa separada da de seus anfitrióes; segundo ele, tal atitude confirma a existência de veneno no líquido que lhe foi servido; desde a tarde em que isso ocorreu, ele começou a se sentir doente. Segundo Mariano, o veneno que lhe serviram era muito forte e objetivava matá-lo, o que não aconteceu por ele estar bem protegido por rezas e dietas que cumpria com freqüência. A razão alegada para a atitude dos envenenadores foi inveja de seus conhecimentos como benzedor. 
A doença durou quase quatro anos, com períodos de melhora e piora. Mariano se automedicava, com medicamentos industrializados, plantas medicinais, das quais é bom conhecedor, e se tratava também com rezas. Admite que o seu estado mental alterado dificultava o cumprimento das dietas necessárias ao tratamento com as plantas, por isso voltava a recair. Questionado sobre o porquê de não consultar um pajé, ele alegou que não tinha dinheiro para pagar o tratamento e que estava certo de que seria capaz de curar a si mesmo com os seus conhecimentos de rezas e fitoterapia. Pelo que foi possível perceber, Mariano tinha conflitos mal resolvidos em sua comunidade de origem, o que o impedia de ir até lá em busca de tratamento para sua doença. Há 13 anos ele nâo retornava à aldeia onde nasceu e viveu até casar-se.

No quarto ano incompleto de doença, ele finalmente começou a melhorar e seu comportamento voltou aos padröes anteriores. Nesse ínterim, ele havia perdido o cargo de capitão para o seu cunhado mais velho. As pessoas toleraram com bastante paciência seu comportamento desregrado, mas em algum momento elas atingiram o limite da suportabilidade e resolveram eleger outro capitão que cumprisse as atividades inerentes ao cargo. A melhora da doença se traduziu também na retomada dos trabalhos comunitários. Mesmo não sendo mais o capitão, ele começou a fazer a reforma da igreja e mudou a cobertura de sua casa.

Quando Mariano estava quase curado, morreu um filho seu. Era um rapaz de uns 24 anos que trabalhava como professor em uma comunidade da calha do Rio Negro. A primeira versão explicativa da morte dizia que o filho de Mariano morrera porque viajava com amigos numa canoa onde todos estavam embriagados. A canoa teria batido numa pedra e virado; como ele estava bêbado, não conseguiu nadar e afogou-se. Essa versão foi veiculada por familiares do morto e num primeiro momento, Mariano pareceu acatá-la, indo a São Gabriel acompanhar o resgate do corpo do filho e o enterro. Quando retornou, sua interpretação dos fatos já era bem diferente: o filho morrera por inveja dos Barés, residentes na comunidade onde o jovem era professor; tinham inveja de um motor de popa que ele havia comprado. Aproveitando um dia de bebedeira, agrediram-no com cacetes e o afogaram no rio. As pessoas presentes no resgate do corpo não confirmaram a presença de sinais de agressão física que corroborassem a nova versão de Mariano sobre a causa da morte.

Depois de reinterpretar os fatos desta maneira, Mariano reagiu de forma depressiva ficando cabisbaixo, calado (bem diferente de seu estilo loquaz habitual), com o olhar perdido no horizonte. Pouco mais de um mês da morte do filho, o encontramos subindo o Aiari para ir até sua aldeia de origem,com a intenção de visitar um tio que é pajé. A razão alegada é que ele queria aprender umas 'histórias' (mitos) para incluir no Manual de Medicina Tradicional Baniwa. Os comentários das pessoas que acompanharam o desenrolar deste drama é que, depois de tantos anos sem retornar para casa, o motivo que o fez ir lá foi encomendar um xamanismo de vingança, um retorno pela morte do filho. 
A riqueza de detalhes do caso $\mathrm{n}^{2} 5$ permite agrupar nele boa parte dos elementos implicados na produção de sentidos de doença na cultura baniwa. Os conflitos entre afins surgem agora entre grupos étnicos distintos que interagem no contexto urbano, mas reafirmando disputas que só encontram um pleno sentido na vida em aldeia. A diferenciação, gerada pela posse de Malikai ou de bens industrializados, desencadeia a inveja que se materializa no veneno e na morte do jovem professor. A ressignificação da morte do filho do informante produz um culpado e a busca de xamanismo de vingança como retorno ao crime. $\mathrm{O}$ efeito protetor das dietas se traduz na capacidade de resistir à morte e na recuperação lenta, mas definitiva do doente. A adoção prolongada de um papel social de doente inviabiliza o cumprimento dos procedimentos necessários à manutenção do cargo, da organização e da limpeza da comunidade.

Caso 6:
Em 1998, fizemos uma longa viagem de observação participante das atividades de Organização Indígena de Base. A equipe de viagem era composta de duas lideranças indígenas, outros dois índios que pilotavam o barco e três mulheres não-indígenas que coletavam material de pesquisa. Um dos locais onde tivemos que parar era uma pequena aldeia na qual morava um benzedor, o único walipere dakenai que pratica essa atividade no Içana e que vive isolado com suas três mulheres e filhos, bem no centro da área evangélica. O local de moradia do benzedor é considerado próximo a uma 'maloca' dos Yoopinai, um local de grande poder em virtude da concentração desses seres naquela região. Para chegar até a aldeia do benzedor é necessário atravessar diversas cachoeiras. Ao chegarmos na última delas, uma das lideranças que viajava conosco veio nos recomendar que tomássemos um bom banho, pois alegava que não teríamos onde nos banhar nos próximos dias; a recomendação soou deveras estranha, pois viajávamos por sobre o Rio Içana onde em quase todo lugar é possível tomar banho. Apesar da estranheza, o banho foi tomado, tendo sido possível observar que os índios também se empenharam num minucioso processo de limpeza de seus próprios corpos.

A viagem prosseguiu sem maiores incidentes até a chegada na aldeia do benzedor; pouco antes da aldeia nos foi mostrado uma enorme pedra próxima da margem do rio que foi identificada por nossos companheiros de viagem como a maloca dos Yoopinai. Após a recepção de chegada, fomos nos alojar e em seguida os índios iniciaram as recomendações, que se perpetuaram durante toda a nossa permanência, sobre as regras de higiene a serem seguidas: banho todos os dias de manhã ao acordar, antes de preparar e ingerir qualquer alimento, lavar as mãos depois de comer, limpar minuciosamente os utensílios domésticos, visando eliminar o cheiro do peixe e da caça. Igualmente qualquer vasilha com alimento deveria ser tampada etc. Essas pressões, sutis mas 
onipresentes, foram repetidas à exaustão durante toda nossa permanência na aldeia e visavam evitar ataques de Yoopinai.

Contrariando frontalmente o que nos havia sido dito, no local indicado para o banho encontramos um esplêndido igarapé. A reconstituição posterior dos eventos mostrou que a liderança usou de um subterfúgio para nos coagir a tomar banho e entrar com os corpos limpos na perigosa moradia dos Yoopinai. $A$ aldeia onde estávamos é localizada no alto de um morro e o igarapé que usávamos para todas as finalidades higiênicas se encontrava muitos metros morro abaixo, de tal forma que tínhamos que subir e descer o barranco inúmeras vezes ao longo do dia.

Após três dias nessa faina, uma das auxiliares de pesquisa de campo passou a apresentar dor aguda no joelho esquerdo. $O$ diagnóstico biomédico foi de uma tendinite, por esforço excessivo; o diagnóstico comunitário foi de flechada de Yoopinai, deixando subentendido que isto havia ocorrido por nấo estarmos cumprindo todas as regras prescritas quanto à higiene corporal..$^{35}$ Iniciou-se, então, um sutil, mas eficiente processo de controle das nossas ações: as pessoas passaram a verificar nossos banhos e a insistir, gentil mas firmemente, para que lavássemos as mãos após cada refeição, pois todos estavam temerosos de ser atingidos por um ataque de Yoopinai.

A tônica deste relato é o controle de gênero estendido inclusive a mulheres não-índias, justificado por sua incapacidade em cumprir as regras de higiene corporal e por suas ligações com a alteridade perigosa. Subjacente a estas representações, surge a idéia de que as ações transgressoras de um indivíduo podem ameaçar não apenas a si próprio, mas a todos os que com ele convivam, mesmo que de forma transitória.

UM CASO DE HIPOLERHI

Caso 7:

Viagem de pesquisa, com parada em aldeia evangélica do sib waliperi dakenai; fomos chamadas pelo capitão da aldeia para atender um doente. Ao adentrarmos na casa, encontramos um jovem com um quadro de conjuntivite com uma fotofobia tão intensa que ele mal suportava a luz da lanterna para o exame do olho. $O$ diàgnóstico feito pela família era de um ataque de Yoopinai, causando Hipolerhi; segundo a familia do doente, o ataque decorreu do fato de que o jovem estava em fase de reclusão pubertária e não cumprira adequadamente as regras de reclusão; saíra de casa sem autorização e se expôs a correntes de ar nas quais havia Yoopinai que atacaram seus olhos. Outras pessoas da aldeia nos procuraram para comentar o assunto; segundo elas, o ataque foi devido à preguiçosa família do doente náo gostar de zelar por sua casa; o telhado da moradia estava velho e cheio de aranhas que haviam atacado o jovem, tratando-se então de um caso de Hirimaka, ou seja, um ataque de Yoopinai através das teias de aranha. 
Apesar da controvérsia em torno de um diagnóstico da causa instrumental, não havia dúvidas de que se tratava de um ataque de Yoopinai, o que as pessoas queriam não era um diagnóstico médico, e sim o medicamento industrializado para tratar o doente. Quando perguntados por que não estavam usando as plantas medicinais de que dispunham, informaram que parte da família do doente estava viajando para uma Conferência Evangélica, impossibilitando o seguimento das dietas que acompanham o tratamento. $O$ doente foi tratado com colírio antiinflamatório, e se restabeleceu após quatro dias de tratamento.

A falta de consenso sobre os nexos explicativos da origem desta doença esconde um campo interpretativo comum, as conseqüências funestas da adoção de comportamentos não condizentes com as regras do bom-viver, sejam a desobediência do jovem ou a preguiça de seu grupo familiar. Apesar do tom moralizante dessa interpretação, a situação encontrada assinala a impossibilidade prática de cumprir certas prescrições rituais que, embora conhecidas e recomendadas, se mostram incongruentes com o contexto enfrentado pelo doente e sua família, produzindo demandas por novas estratégias terapêuticas (Abric, 1994).

Boa parte dos relatos se caracteriza pela ausência de consensos interpretativos sobre os sentidos da doença, cuja explicação de origem pode variar conforme as posições ocupadas por cada participante da cena social onde se desenrola o drama representado pela eclosão dos sintomas. Seu estudo é elucidativo das contradições e ressignificações dos sentidos de doença e das tentativas, bem ou mal-sucedidas, de utilizá-los como obstáculo às transgressões, num meio social que dispõe apenas de meios tênues para fazê-lo. Sanções e proibições são tentativas de organizar o ambiente, reduzir a ambigüidade e preservar a ordem ideal da sociedade; tais processos costumam comportar contradições entre a experiência e a norma, promovendo mútuo redimensionamento destes termos (Douglas, 1976).

Caso 8:

LidERANÇA INDÍGENA É ATACADA COM MANHENE

Maurílio, presidente de uma importante organização indígena baniwa, está doente; acredita estar envenenado há sete meses. Ele vem apresentando freqüentes episódios diarréicos, com sangue e pus, indisposição estomacal, gases intestinais e perda de peso acentuada; ao longo do período de doença chegou a perder mais de nove quilos. Como uma persistente dor de cabeça o impedia de dormir, em uma de suas viagens se obrigou a combater a insônia tomando algumas cervejas, a única forma de relaxar e conciliar no sono; tal situação lhe gerou conflitos morais, pois, sendo evangélico, é abstêmio convicto. Os sintomas físicos se acompanham de outros mais subjetivos e mais exuberantes caracterizados por pesadelos, dificuldade de concentração, sensação de fraqueza, sentimentos depressivos e uma avassaladora certeza de que pode 
sucumbir à ação do veneno; se tal não ocorrer neste episódio, considera a morte inevitável em outro ataque. Igualmente acredita que o envenenador pode transferir suas atividades maléficas para outro membro de sua família. Nos últimos tempos os pesadelos, que foram tratados por um de seus tios, um pajé Hohodene que mora em Barcelos, desapareceram. Os pesadelos interpretados pelo pajé tinham como ponto comum a idéia subjacente de agressão - tentativa de assassinato - por um xamã inimigo. Dentre os temas mais freqüentes pode ser citada: a ingestão pelo doente de carne de anta, $o$ animal representativo de seu sib (os walipere dakenai são os netos da anta); em diversos sonhos se via comendo o coração do animal. Em outras ocasióes sonhava com objetos que demarcam suas atividades cotidianas em perigo de destruição iminente; assim, via o bote em que viajava, virado e afundado nas cachoeiras que costumava percorrer no desempenho de suas atividades. A interpretação oferecida pelo xamã sobre a ingestão de anta e a destruição de seus objetos pessoais é a mesma: ambas situações representavam a ameaça de destruição do envenenado por um xamã contratado para assassiná-lo. Os pesadelos cessaram após a realização dos procedimentos de cura que atribuíram tais sentidos às produções oníricas do doente.

Por vários meses a liderança enferma tentou diversos tipos de tratamento; inicialmente procurou cuidados domésticos como o uso de plantas, obtendo melhora do quadro, mas nunca uma remissão completa; posteriormente em São Gabriel procurou uma benzedeira de outra etnia, que diagnosticou ataque de Yoopinai, prescrevendo plantas e dietas com plantas medicinais. Ele apelou ainda para preces cristâs, benzimentos maliri, tendo por fim, apesar de suas crenças evangélicas, buscado tratamento xamânico, por absoluta falta de resposta às outras tentativas.

Em uma ocasião foi procurado por um pajé Puinave, residente na área dos Curipaco; o pajé já o conhecia das atividades da Organização que dirige e veio se oferecer espontaneamente para tratá-lo; fez benzimentos, tratamento com plantas que igualmente trouxeram melhora, mas não cura. Este xamã o alertou que seu problema era grave, pois tratava-se de uma associação de uso de veneno (omai panattemi) com uma agressão xamânica encomendada por outro Baniwa desejoso de assassiná-lo. Segundo o Puinave, o xamã homicida ficava sempre a espreita, enviando agressões; o diagnóstico era tão grave que o próprio Puinave já estava receoso de que os agressores de Maurílio se voltassem contra o seu terapeuta. $O$ doente começou a usar as plantas recomendadas pelo terapeuta Puinave, mas estava com dificuldade de custear o tratamento, pois o mesmo cobrava 50 litros de gasolina em paga de cada remédio, já pronto, que lhe ministrava.

Ao longo de todos os frustados tratamentos, ele vem fazendo as rigorosas dietas baniwa, embora não consiga cumpri-las pelo tempo necessário porque a pesada agenda de viagens, inerente às suas atividades políticas, impossibilita o correto cumprimento das restriçōes dietéticas. No mês de janeiro de 2001 teve uma acentuada piora da sintomatologia, chegando a ter dez episódios 
diarréicos por dia, passando a se sentir depois disso, muito fraco e tonto. Na ocasião buscou atendimento com a equipe no serviço de saúde, mas não recebeu a atenção devida; foi então procurar seu pai, que estava morando em uma comunidade baniwa localizada na calha do Rio Negro. Foi tratado por ele com plantas medicinais, obtendo uma boa melhora dos sintomas; entretanto, dias depois teve que comparecer a uma assembléia no Içana, na qual the foi servido paca (animal de pêlo, proibido aos doentes de Manhene) o que provocou nova recaída e recrudescimento dos sintomas.

As manifestaçôes da doença são intermitentes, melhorando com os tratamentos e piorando com a ingestão de comidas proibidas para uma pessoa envenenada. Como a doença vem avançando, atualmente sua alimentação está reduzida à farinha e a dois tipos de peixe. Quando os sintomas pioram, opta por jejum total, o que tem agravado a perda de peso.

Finalmente chegou a São Gabriel da Cachoeira o pajé hohodene supracitado, seu tio materno, há muito emigrado para Barcelos. Por recomendação do mesmo ambos foram extrair os ingredientes próprios para preparar o Paricá, usado pelo hohodene numa sessão de cura na qual sugou a cabeça e o estômago da vítima. O tio localizou no abdômen o foco original da doença, identificando uma região abaixo do umbigo como o local de ação do veneno; a dor de cabeça seria apenas conseqüente à lesão digestiva. Finalmente o xamã declarou-se incapaz de curá-lo completamente, caso o mesmo permanecesse desempenhando atividades políticas frente à Organização Indígena.

Em vista disso, Maurílio voltou a procurar tratamento biomédico no Distrito Sanitário Especial Indígena; fez exames de sangue e fezes sem que nenhuma doença fosse detectada; recebeu uma prescrição de remédio para vermes, mas não obteve melhora; posteriormente recebeu do enfermeiro do Distrito Sanitário um medicamento destinado ao tratamento de gastrite, mas também não observou melhora de seu quadro. Em termos biomédicos foi possível observar que o doente não recebeu diagnóstico e tratamento adequados, havendo incúria na investigação do problema.

Como os sintomas continuassem, a liderança optou por buscar tratamento em Manaus, submetendo-se a uma complexa bateria de exames de sangue, fezes, ultra-sonografia, raios $X$ e endoscopia. Os exames evidenciaram a presença de uma maciça infestação por parasitas que costumam perfurar a mucosa intestinal e que foram devidamente tratados; não houve outros achados clínicos que pudessem indicar a associação com outra patologia. O tratamento obteve a remissão dos sintomas, mas, segundo o entendimento do doente, trata-se de uma remissão temporária, pois considera inevitável que eles reapareçam, seja ainda neste episódio de envenenamento, seja em outra agressão futura.

A contextualização sociopolítica do caso de doença mostra que este prolongado episódio é apenas a atualização de uma série de situações conflituosas que vem ocorrendo há mais ou menos cinco anos, envolvendo tensões intrafrátricas. 
A primeira dessas situações se origina na discordância de um influente capitão quanto às formas de atuação da Organização Indígena; a insatisfação se liga a uma não distribuição de bens captados pela Organização, aos quais o capitão acreditava fazer jus, em troca do apoio político que emprestou à Organização. Pouco tempo depois da eclosão deste conflito, a liderança adoeceu e várias pessoas associaram seus sintomas à ação de um possível envenenador. Não houve acusações públicas, mas apenas comentários velados de que o rancoroso capitão poderia estar ligado ao aparecimento do problema.

Quase um ano depois ocorreu outro incidente, envolvendo os pais do doente e o capitão da aldeia - igualmente seu consangüíneo - onde todos residiam. O clima de tensão decorria da disputa pela ocupação de posições de prestígio e das responsabilidades delas decorrentes; não chegou a haver um conflito aberto entre os contendores, mas a esposa do capitão adoeceu e a família da liderança foi acusada, através de boatos, de ter mandado fazer um sopro para a mesma. $\mathrm{O}$ conflito nunca foi completamente resolvido e as tensões continuaram de forma subterrânea, culminando com a decisão da família da liderança de passar uma temporada em São Gabriel, como uma forma de acomodação dos conflitos.

Aos olhos do doente tais situações não são elementos isolados entre si, sendo, ao contrário, um conjunto de eventos interdependentes agrupados num único cenário. Seriam conseqüência de atitudes agressivas de pessoas invejosas do sucesso e prestígio obtido pelo doente, e por extensão por sua família, na condução de um vitorioso ativismo etnopolítico, no qual sua atuação gerou uma série de bem-sucedidas realizações do movimento indígena na área evangélica, anteriormente refratária a tais práticas.

Refletindo sobre o seu problema o enfermo relembra que sempre teve uma grande preocupação em não acumular bens para si e para sua família, evitando uma diferenciação nítida dos modos baniwa de viver, para não incorrer nas infrações de comportamento que costumam despertar a inveja das pessoas; entretanto, ele mesmo conclui que o prestígio e o sucesso de seu trabalho já são motivos suficientes para desencadear ações agressivas deste porte, mesmo que suas atividades tenham se pautado pela preocupação em redistribuir de forma equânime os bens captados pela entidade que dirige. O próprio sucesso financeiro e administrativo da Oibi poderia ter dado origem à agressão, ainda que o doente não tenha retido nada para si e para sua família. A mudança para São Gabriel também surge como outro fator de reforço à violência das ações de envenenamento, pois ela é interpretada pelos que estão nas aldeias não como uma decorrência de tensões intra e intercomunais, mas como a busca de uma nova distinção: morador da cidade.

Os benzedores consultados foram unânimes em afirmar que o envenenamento seria uma decorrência direta de seu bem-sucedido trabalho como liderança e que ele poderia superar este episódio de doença; mas, caso persistisse 
na carreira de líder político, novos e mais violentos ataques de veneno se sucederiam, incidindo sobre sua própria pessoa ou sobre outro membro de sua família. O envenenamento seria o 'troco' ou retorno (na forma de inveja e agressão) pela diferenciação produzida no trabalho político. Para os benzedores consultados, a única forma de afastar ou reduzir o risco de novos episódios de envenenamento seria o afastamento permanente das atividades políticas.

Assim, o doente está entre duas opções extremas, que implicam dano. Ele pode manter-se no trabalho político, sabendo que vai se imolar pela causa; neste caso ele conviveria com a certeza de morte ou doença crônica que inexoravelmente iriam atingi-lo ou aos membros de sua família nuclear. Se isso ocorresse, além do sofrimento pela própria doença, receberia a culpa por ter contribuído, mesmo que involuntariamente, para a doença ou a morte de um membro da família, que sofreria as conseqüências de sua opção; nestas circunstâncias a permanência na militância etnopolítica não deixa de ter um 'quê' de suicida. A outra opção seria abandonar o movimento indígena, preservando o corpo e a saúde, uma vez que seus riscos diminuiriam com o anonimato; em troca sacrificaria seu projeto de vida, seus ideais, os planos futuros traçados em torno do trabalho etnopolítico. Na primeira opção ele corre o risco de perder a vida ou a saúde, na segunda ele arrisca perder a essência do projeto político que orienta sua existência.

O informante garante não ter nenhuma idéia da identidade de seu agressor; mais do que isso: há uma opção explícita de não querer conhecer esta identidade; é uma forma de proteção, um meio de bloquear o circuito de violências que poderiam ser ininterruptamente desencadeadas caso houvesse morte de algum dos membros de sua família. Recusar-se a conhecer a identidade do envenenador é um modo de evitar seu próprio desejo de retaliação e de limitar o risco de irrupção da violência incontrolada. Além disso, conhecer a identidade do agressor nada acrescentaria ao prognóstico ou às formas de tratamento da patologia.

Outra dimensão do evento são suas repercussões políticas; na área baniwa o problema é de domínio público e a militância política (com suas potenciais conseqüências) está sub judice. $\mathrm{O}$ doente e seus interlocutores crêem que, em caso de morte ou de cronificação da doença, a tendência seria um refluxo do trabalho político de todas as organizações que lá atuam; o temor de sofrer sina semelhante está impresso nas mentes dos militantes etnopolíticos do Içana e Aiari que aguardam o desfecho do caso e sabem que boa parte de suas ações futuras será pautada por ele. Há um risco reconhecido como real de que o inventivo movimento indígena baniwa tropece num episódio de envenenamento e sofra um refluxo.

A liderança enferma está presa na armadilha de uma cultura que tem no Manhene a importante tarefa política de inibir a diferenciação social, ainda que ela seja bem intencionada e respaldada em fortes propósitos morais e de interesse do bem comum. A mesma estratégia que impede a diferenciação - e mantém um 
dos pilares da ordem social baniwa - também dificulta as ações de seus membros inovadores, fontes internas de estratégias de transformação social. As mudanças trazidas pelo movimento etnopolítico, ainda que desejadas e bem-sucedidas, contêm em si próprias uma subversão da ordem que o corpo social procura circunscrever e reenquadrar a partir dos sentidos do envenenamento. $O$ doente pode ser considerado uma vítima sacrificial do embate entre sincronia e diacronia no mundo baniwa.

\section{Reafirmando os sentidos sociopolíticos da doença e cura}

O estudo dos casos de doença permite relativizar a supervalorização da ordem social a que os relatos míticos nos conduzem; eles evidenciam as contradições, hesitações, imprecisões, heterogeneidade e a indeterminação que coexistem na vida real de pessoas capazes de manipular as categorias explicativas colocadas ao seu alcance pela cultura. As situações práticas mostram que as representações sociais sobre saúde, doença e cuidados estão longe de ser um sistema fechado, homogêneo e determinista; ao contrário, o conjunto das representações e práticas se configura como um espaço aberto, comportando inúmeras contradições, dúvidas e incertezas que permitem sua ressignificação e transformação históricas (Flament, 1997).

Se tomarmos os modelos etiológicos de doença descritos por Laplantine (1991), observaremos que para os Baniwa o processo patológico é algo essencialmente 'relacional', ou seja, ligado à ruptura do equilíbrio entre o homem e seu meio social e entre o microcosmo humano e o macrouniverso dos deuses. Os procedimentos de cura buscam o reequilíbrio cósmico, reafirmando uma relação necessária de continuidade entre corpo biológico e corpo social, entre indivíduo e sociedade e entre singular e universal (Augé, 1986).

O sofrimento gerado pelo estado de doença atinge não só o corpo do indivíduo doente, mas também todo seu grupo social, ameaçando alastrar o desequilíbrio pelo universo. Ao advertir sobre uma infração (voluntária ou não) das normas sociais, esta concepção trai um componente moral-religioso, que exige uma re-harmonização feita mediante procedimentos sacrificiais reparatórios. $\mathrm{O}$ indissolúvel vínculo dos agnatos se expressa em rituais como os kalidzamai de nascimento nos quais a reclusão e o jejum visam proteger o bebê das inevitáveis agressões geradas nas atividades rotineiras dos pais, que matam peixes e animais, cortam árvores e perfuram a terra. Pai e criança formam uma unidade, os atos de um refletirão no outro; os procedimentos rituais que purificam e fortalecem o pai se estenderão à criança, protegendo-a das retaliações dos seres da natureza (Hill, 1989). Nessas ocasiões a obrigação de jejum se estende também à mãe, não pela 
lógica da consangüinidade, mas porque os alimentos agressivos ingeridos por ela podem atingir a prole através do leite.

A patogênese decorre de aumento da agressividade de uns, da diminuição da capacidade de resistir e revidar de outros, ou ainda da associação de ambas condições; a persistência dos sintomas aponta para uma mudança progressiva no ser do doente, que tende a escorregar para o domínio da alteridade. Nos tempos ancestrais, essa mudança qualitativa se expressou na transformação de gente em Yoopina $^{36}$ e hoje pode se atualizar num envenenado que se comporta como um animal. A maldade inerente ao canibalismo, a guerra, a desobediência e a sexualidade irrefreada origina a impureza, o caos, a dor, o sofrimento e a morte.

Saúde e preservação da ordem são elementos indissolúveis entre si. $\mathrm{Na}$ cultura baniwa a prevenção da doença passa pela manutenção das regras matrimoniais, de solidariedade entre consangüíneos, respeito à hierarquia de gênero e de geração, de generosidade e restrição da predação exercida sobre os seres da natureza. As transgressões dos ancestrais e dos atuais viventes produzem poluição corporal, espiritual e cósmica que torna o mundo um lugar sujo, cheio de veneno e de maldade, demandando cuidados que têm por objetivo restituir uma limpeza e a pureza capaz de reaproximá-lo do belo, limpo e brilhante céu de Nhiãpirikoli (Wright, 1993/1994). Tais idealidades não deixam de coexistir com situações em que são concretamente negadas.

A perpetuação mítica da morte, doença, poluição e da desordem impossibilitam um estado perene de saúde, transformando a vida social num permanente palco de luta para afastar o caos e preservar o bem-estar. Viver é um estado perigoso que demanda ritos sacrificiais nos quais se trocam abstinências diversas pela saúde e o bem-estar. É desta forma que podem ser mais bem compreendidos a doença e os cuidados de saúde baniwa, como relações de troca estabelecidas entre grupos humanos e não-humanos; a doença é o 'troco', a retribuição pelas ações agressivas humanas e de seus ancestrais. A obtenção da cura se dá por restrições temporárias que visam restaurar o balanço positivo para os humanos no mercado de trocas simbólicas.

Sendo um evento simultaneamente político e moral no qual coexistem diferentes formas de interpretar a cosmologia e a realidade cotidiana, a doença expressa o conflito, e as terapêuticas objetivam reacomodar os sentidos a ele atribuídos, garantindo, ainda que transitoriamente, consensos de interpretação e de intervenção sobre os eventos sociais. As restrições dietéticas e sexuais e as medidas de prevenção ao ataque das estrelas são disciplinas corporais e espirituais que buscam reafirmar a condição humana por meio do controle dos impulsos, da frugalidade, da renúncia voluntária aos prazeres e da obediência às normas estabelecidas pelos ancestrais no primeiro ritual de iniciação. 
Jejuns retiram o ser humano do grupo de predadores, onde ele se iguala ao animal; a proibição da pimenta simboliza o abandono da condição de predador, demarcando uma fronteira entre o doente envenenado e os agressores que geraram a doença, redefinindo e reafirmando os marcos entre humanidade e seres da natureza. O veneno traz Kowai para o interior do corpo enfermo; a ingestáo de pimenta e de animais reimosos pode desequilibrar a balança e precipitar definitivamente o doente no domínio dos seres canibais. A dieta busca romper o vínculo com os inimigos da humanidade, reafirmar a condição humana, garantir a reprodução das vitórias de Nhiãpirikoli e a manutenção da ordem humana no cosmos.

Além das finalidades terapêuticas já assinaladas, o alimento tem grande importância em outras dimensões da vida cotidiana. A partilha de comida tem um importante papel na gestão das relações travadas entre as famílias de uma aldeia, que costumam fazer pelo menos uma refeição comunal no dia. Journet (1981) descreveu a refeição comunitária, habitualmente organizada pelo capitão, como um espaço onde as pessoas exercitam uma reciprocidade obrigatória na qual cada família nuclear deve contribuir com algum tipo de alimento, que passa a compor um acervo comum a ser redistribuído eqüitativamente entre todos os presentes; garante-se, assim, a sua circulação e o cumprimento das obrigações de generosidade, exigidas particularmente dos que ocupam alguma posição de prestígio. A refeição comunitária é também um espaço político que permite ao capitão avaliar periodicamente seu prestígio com seus liderados, investigar a potencial existência de conflitos e desentendimentos entre os membros da aldeia, utilizando a mesma ocasião para dirimi-los e aglutinar esforços dos diferentes membros do grupo para a realização de tarefas comunitárias que exijam a colaboração de todos.

Durante a refeição comunal, exercita-se a disciplina e a frugalidade; a avareza na distribuição de provisões e a voracidade no seu consumo são comportamentos censuráveis. A etiqueta baniwa recomenda que o alimento não deve ser oferecido, e sim servido com generosidade; quem tem fome ou gula está terminantemente proibido de pedir o que deseja, deve recusar educadamente um alimento que lhe é oferecido e evitar um comportamento voraz ao consumir o que lhe foi servido. Quanto maior a fome, mais se deve aparentar indiferença. O princípio humanista subjacente a estas regras de comportamento é a prevalência do coletivo perante o indivíduo, a preeminência do direito do outro em detrimento do meu próprio. Esses comportamentos cotidianos disciplinam os sentimentos, os corpos, as vontades e os estômagos, preparando-os para enfrentar os períodos de escassez de comida, os rituais de passagem e as dietas com finalidades terapêuticas ou preventivas.

A faceta política do evento patológico também permite concebê-lo como um espaço de relações assimétricas, de competição e cooperação entre grupos. Nele, a busca de hegemonia passa pela obtenção e controle dos conhecimentos 
(malikaı) que viabilizam a cooperação e formação de alianças intra e interaldeias, entre sibs e fratrias. $\mathrm{O}$ controle dos meios simbólicos de produção confere autoridade e legitimidade a seus detentores, possibilitando tornar hegemônicas suas interpretações sobre os sentidos da doença, favorecendo o exercício de poder nos diversos domínios da sociedade. $\mathrm{O}$ desempenho de um papel social de doente propicia validações e contra-validações das ações dos membros da sociedade; os diagnósticos operam como fontes privilegiadas do poder de limitar comportamentos abusivos dos membros do grupo, fornecendo também critérios de validação e avaliação de ocupantes de cargos políticos.

31 Essas expressões nos remetem a uma divisão segundo um critério biológico, mas também à segmentação interna de sibs divididos em 'mais velhos' e 'mais novos', de acordo com sua origem ancestral.

32 Todos eles pertencem a sibs distintos do de Leandro.

33 Só como informaçăo adicional, cabe dizer que a aldeia de Leandro (o qual na prática exerce o papel de capitão, pois seu pai é muito velho para exercer efetivamente o cargo) é bastante organizada, tendo uma escola grande, grupo gerador, antena parabólica e outros bens industrializados capazes de gerar a cobiça de seus vizinhos. Seus dois irmãos mais novos são empregados como agente de saúde e professor, recebendo salários regulares.

34 Esta condição era agravada pelo fato de que tanto a mulher quanto o marido eram portadores de sarna, disseminada por todo o corpo; entretanto, as reações ante a sarna no homem eram bem mais amenas que a rejeição à sarna na mulher 'estragada'.

35 Existe uma persistente associação entre os brancos, suas mercadorias e o mau cheiro, a putrefação e a doença; brancos e o cheiro de suas secreções são assimilados aos peixes-espíritos e outros seres da floresta como os Awakaruna.

36 O texto de Wright (no prelo) corrobora estas mesmas idéias no contexto da bruxaria. Segundo o autor, os Baniwa consideram que o envenenador contumaz aparenta uma forma humana, mas tem uma natureza distinta daquela das pessoas normais; em algum momento de sua existência, o desejo obcecado de matar com veneno fez que com ele cruzasse as fronteiras da humanidade e se transformasse num macaco Eenunai, um ser-espírito canibal. 
Política, Moral e Legitimidade no Mundo Aldeão 



\section{Hierarquia, Guerra, Alteridade \\ e Poder na Ancestralidade}

Os temas aqui tratados fornecem uma transição dos aspectos mais internos da cultura baniwa para o entendimento das atividades políticas das Organizações Indígenas do Içana e Aiari voltadas simultaneamente para o gerenciamento das interações entre sibs e fratrias e para a mediação das relações interétnicas analisadas nos próximos capítulos. Tais informações são relevantes para mostrar como se configuram as relações internas de poder nesse grupo étnico, visto que as mesmas modulam a atuação das entidades etnopolíticas em defesa de seus direitos e na busca de implementar políticas públicas de seu interesse.

O primeiro passo desta tarefa é a análise de como se estabelecem as relações hierárquicas entre os sibs e fratrias baniwa, sem desconsiderar o processo histórico de contato interétnico que provocou alterações significativas em sua expressão. Os dados coletados indicam que tais hierarquias são relevantes para a definição e ocupação de cargos políticos, para legitimar lideranças e garantir ou retirar apoio a sua atuação no âmbito da aldeia, no movimento indígena, na ocupação de assentos durante os conselhos de saúde ou no trabalho de agente de saúde.

Por meio dessa discussão, far-se-á seqüencialmente a transição do microcenário aldeão para o contexto sub-regional formado pelo conjunto de aldeias do Içana e do Aiari, e posteriormente para as realidades regional e mundial/global, que são o palco da ação na Federação das Organizações Indígenas do Rio Negro (Foirn). Ela será utilizada como base de apoio para a problematização da atuação das Organizações Indígenas no contexto do mundo contemporâneo, explorando também sua interface com instituições do mundo não-indígena e/ou que lidam com temática indígena, mas atuando principalmente nos contextos urbanos, como é o caso da Foirn. Nesse quadro, os sinais diacríticos da cultura de origem se tornam instrumentos de luta pela obtenção/ampliação de direitos sociais oriundos da condição de minoria étnica.

A base de dados sobre a qual foi construída esta parte do estudo é proveniente da área coberta pela Organização Indígena da Bacia do Içana (Oibi) e Associação das Comunidades Indígenas do Rio Aiari (Acira), pois as duas entidades representam os tipos mais atuantes e melhor estruturados de Organização Indígena 
nessa região. Secundariamente foram coletados dados junto à área de cobertura da Organização Indígena dos Curipaco do Alto Içana (Oicai) e União das Nações Indígenas Baniwa (Unib); essas organização são mais recentes e de menor impacto e relevância política nessa sub-região rionegrina.

Um dos propósitos essenciais da discussão é demonstrar a conexão existente entre as formas internas de exercício de poder no mundo baniwa e as maneiras como ele se expressa nas atividades engendradas no processo histórico de contato, no qual se enquadram as políticas indigenistas e as políticas de saúde. Os dados coletados indicam que a cosmologia baniwa permanece orientando as concepções políticas subjacentes às idéias de doença, cura, chefia, representatividade, legitimidade etc.; ou seja, a atuação de agentes de saúde, lideranças de Organizações Indígenas, conselheiros de saúde e outros elementos da modernização é pautada por regras e expectativas oriundas do pensamento mítico, que atribui novos sentidos às práticas geradas no contato interétnico. Simultaneamente, a influência dos saberes/poderes veiculados por elementos do mundo não-indígena também contribui para o redimensionamento interno das bases míticas da sociedade baniwa. A caracterização desse circuito de poder exige uma análise da atuação não apenas dos atores políticos supracitados, mas também da chefia de aldeia, o chamado capitão, cujas atuais atribuições são também um produto das relações de contato, que guardam, no entanto, fortes vínculos com noções nativas de poder e autoridade.

Em seus estudos sobre sociedades indígenas sul-americanas, SantosGranero (1994:263) mostra que o campo do poder pode se desenvolver através de quatro níveis básicos de interação: "nível cósmico, nível da política interlocal, nível da intralocalidade e nível do parentesco, englobando também o matrimônio". O nível cósmico foi trabalhado no capítulo que trata das representações de doença e cuidados de saúde e aqui procurar-se-á explorar esses outros nichos do exercício de poder, uma vez que tratamos com sociedades que não desenvolveram instituições capazes de impor a seus membros determinações alheias às suas vontades. Nesse caso elas são obrigadas a desenvolver estratégias de convencimento e relações de compromisso entre seus membros, o que habitualmente se dá mediante as relações do parentesco, que também configuram as formas de expressão da política local nas aldeias e interlocal, ou seja, as interações entre os sibs e as fratrias residentes em localidades distantes entre si.

Tais interações são descentradas, permeando toda a sociedade e se exercendo nas vivências rotineiras do dia-a-dia, e não apenas em ocasiões ou eventos espetaculares ou pontuais (como um julgamento ou uma execução, por exemplo). Como esses grupos sociais também não costumam dispor de instituições especializadas - como, por exemplo, o poder judiciário - para exercer a coação da sociedade sobre seus membros, as formas de garantir a cooperação dos sujeitos e a 
adesão às normas sociais passam pelo exercício desses micropoderes que perpassam e ordenam a vida cotidiana. É nesse âmbito que se inscrevem as representações de doença, cura e cuidados e as relações hierárquicas entre os sibs e as gerações, que expressam a busca da garantia de reprodução da ordem social entre os Baniwa.

Marshall Sahlins (1997a, 1997b) traz uma contribuição decisiva para o entendimento do modo criativo como os Baniwa vêm redimensionando sua própria cultura, não apenas para lidar com as condições históricas que vêm enfrentando ao longo do processo colonizatório, mas também para fazer face às necessidades e prioridades inerentes ao próprio grupo. O autor examina como, em situações de encontro intercultural, os povos indígenas tentam integrar elementos da sociedade mundial ao seu próprio sistema de mundo, entrelaçando histórias locais às contingências dos circuitos econômicos mundiais. A partir das condições nativas de atuação, eles são capazes de produzir efeitos específicos de expressão das forças materiais globais em esquemas culturais locais (Sahlins, 1988:53).

Sem negar a condição de assimetria e dependência do mercado capitalista, Sahlins caracteriza tais estratégias como formas de auto-realização cultural, em escala material e simbólica, responsáveis por continuidades culturais que comportam em si a possibilidade de mudança. A continuidade é vista não como sinônimo de imobilidade; neste caso "a tradição consiste nos modos distintos como se dá a transformação: a transformação é necessariamente adaptada ao esquema cultural existente" (Sahlins, 1997a:62).

Para este antropólogo,

as pessoas organizam sua experiência segundo suas tradições, suas visões de mundo, as quais carregam consigo também a moralidade e as emoçōes inerentes ao seu próprio processo de transmissão. As pessoas não descobrem simplesmente o mundo: ele lhes é ensinado (Sahlins, 1997a:48).

Uma sociedade enfrenta novas condições de vida e incorpora as mudanças a partir das instituições preexistentes, que podem ser redimensionadas internamente no processo de incorporação dos novos elementos da vida social; o resultado final costuma, portanto, ser diferente dos elementos que constituíram originalmente' o processo.

Dessa maneira, tentaremos analisar as estratégias baniwa de incorporação de bens e serviços da sociedade industrial, sobretudo as dos bens e serviços de saúde, demonstrando que tal incorporação é coerente com as formas prévias de organização da sociedade, do exercício do poder político e dos valores morais, comportando, por isto mesmo, finalidades bem diversas daquelas para as quais foram originalmente concebidos. $O$ processo pode ser descrito como uma conjugação entre a "economia de mercado" e a "economia do dom", na qual os bens e serviços incorporados passam a se inserir nos circuitos de trocas cerimoniais recíprocas, 
visando à geração de prestígio e outras formas de poder simbólico que, do ponto de vista nativo, são conquistas mais importantes do que o cumprimento de prescrições das instituições onde obtiveram tais benefícios sociais (Sahlins, 1997a:53). A adesão a práticas institucionais não-indígenas não é sinônimo de abandono da afiliação tribal, podendo significar inclusive uma maior aderência à mesma.

$\mathrm{O}$ autor formula o conceito de cultura como "organização da experiência e da ação humana por meios simbólicos... manifestando-se essencialmente como valores e significados" (Sahlins, 1997a:41). Assim, a cultura deve ser entendida como os meios pelos quais um povo representa a si mesmo como entidade social distinta e em interação com outros grupos sociais, e como produtora de formas e normas culturais que não são prescritivas do comportamento dos membros da sociedade; tais normas seriam apenas orientadoras, deixando grande espaço para a intencionalidade e a inventividade dos sujeitos.

Essas são premissas essenciais para a análise da trajetória dos diversos tipos de líderes políticos baniwa, pois boa parte de sua legitimidade de atuação é fundada em meios simbólicos de intervenção na sociedade, sendo fortemente regulada por valores morais que propiciam critérios de avaliação de seu desempenho pelos liderados. Como muitas situações atualmente enfrentadas por eles não estão contidas e/ou previstas nas normas culturais, compete-lhes reinterpretar criativamente os elementos de cultura colocados a seu dispor, para elaborar parâmetros de interpretação e de intervenção sobre a realidade nativa e aquela gerada no contato intercultural.

Algumas proposições de Sahlins (1983) são essenciais para a caracterização dessa reconstrução cultural. A primeira delas é a tipologia de reciprocidade, estratificada por ele em 'generalizada', 'equilibrada' e 'negativa', podendo ser praticada entre consangüíneos, afins e inimigos para regular o fluxo e intensidade dos bens e serviços distribuídos (ou negados), bem como as obrigações de retribuição daí decorrentes.

Esta circulação ritualizada de bens e serviços feita através de prestações e contraprestações entre membros da sociedade remete à caracterização de Overing (1983/1984) da chamada "antropologia política dos bens", ${ }^{37}$ e à noção de "antropologia política das pessoas" desenvolvida por Rivière (1984). ${ }^{38}$ Ambos os conceitos subentendem uma contraposição à economia de mercado, centrada no controle/expropriação dos produtos do trabalho, no lucro e na acumulação, e a existência de mecanismos que instauram a circulação obrigatória dos produtos, regulada pelas regras de reciprocidade.

A organização social baniwa se caracteriza como uma economia política centrada nas pessoas e organizada, tal como aponta a literatura, em torno do controle hierárquico dos sibs, das gerações e do gênero, por meio do qual busca potencializar e garantir sua reprodução. $\mathrm{O}$ advento de novas instituições como as Organizações 
Indígenas tende a se inserir nas condições pré-existentes e a integrar os circuitos de reciprocidades estabelecidos entre afins e consangüíneos e de relações conflituosas com a alteridade, passando a fazer parte dos modos como os Baniwa vêm reproduzindo seu sistema-mundo nas condições atuais de vida.

Para iniciar uma análise dos dados coletados entre os Baniwa, descreveremos um dos importantes elementos organizativos dessa economia política, ou seja, a distribuição dos sibs e fratrias pelo território ancestralmente ocupado por eles; tal distribuição é relevante para a análise da influência política atual das Organizações Indígenas, que é de base geopolítica.

A tradição oral baniwa situa os igarapés Uarana, afluente do Rio Aiari e Pamaali, afluente do trecho médio do Içana, como os locais de assentamento ancestral das fratrias Hohodene e Walipere, respectivamente. Os sibs Dzawenai eram ocupantes e guardiães das áreas do Içana onde se formaram os lagos piscosos, seja no Médio, seja no Baixo Içana.

A sucessão de perseguições e violências a que os Baniwa foram submetidos no processo colonizatório os levou a se internar nas cabeceiras de rios e igarapés e a evitar as margens dos grandes cursos d'água, onde se tornavam mais vulneráveis aos ataques. A rememoração feita hoje pelos informantes mais velhos reconstrói a movimentação contrária, quando a população volta a se deslocar, desta vez para reocupar as margens dos grandes rios após a redução das incursões de aprisionamento.

Por meio dos relatos e do mapeamento dos atuais sítios de moradia, pode-se observar que a distribuição dos sibs e fratrias difere do antigo padrão de ocupação apenas pelo deslocamento dos igarapés para as margens do Içana e Aiari, mas sem um afastamento significativo das regiões ancestralmente ocupadas; no caso específico do território Dzawenai, na prática não há uma mudança significativa entre os locais ancestrais de ocupação e os atuais. Assim, ao longo do tempo, as margens do Baixo Içana e os trechos de lagos têm sido ocupados pelos sibs Dzawenai, o Médio Içana pelos Walipere e o Alto Içana pelos Curipaco; a sub-região do Rio Aiari e afluentes tem sido historicamente ocupada pela fratria Hohodene (Ver Anexo, Mapa 2).

Os padrões de assentamento baniwa seguem uma lógica bem distinta do modelo descrito na literatura para os grupos Tukano, no qual os sibs 'de cabeça' habitariam preferencialmente os trechos mais largos de rio (Jackson, 1983). Apesar das mudanças geradas no processo colonizatório, observa-se uma bem definida divisão do território entre as fratrias, que não guarda relações necessárias entre status de sib e ocupação de trechos mais largos do rio. O padrão ancestral, em boa parte mantido, é definido na produção mítica que preconiza a destinação de subregiões por grupo frátrico, congregando na mesma área os sibs de diferentes classes de status, pertencentes à mesma fratria (Wright, 1989). 
As três fratrias baniwa residentes no Brasil são Dzawenai, constituídas por um número de sibs que varia entre cinco e sete, cuja principal área atual de assentamento é o Baixo Içana. ${ }^{39} \mathrm{O}$ Médio Içana é área de influência dos sibs Walipere; o assentamento de três aldeias Dzawenai nessa região é congruente com a sua condição de 'donos' dos lagos, pois elas estão assentadas na proximidade de lagos piscosos do Médio Içana. O alto do rio é área auto-identificada como curipaco, ${ }^{40}$ com diversos sibs que compartilham este dialeto e que mantêm relações de exogamia com membros das outras fratrias. O Rio Aiari por sua vez é área de influência da fratria Hohodene; nele também existem cinco assentamentos Walipere e um Dzawenai, cuja história de ocupação remete aos já citados acordos entre sibs.

Como já foi dito, a hierarquização demarca as interações entre os sibs, mas no interior deles os indivíduos convivem também com um ethos igualitário particularmente entre os homens de uma mesma geração - que envolve elementos de desempenho e competição, que travam entre si, nas atividades de produção da subsistência (Wright, 1992a:261). Esses dois pólos provocam um campo de tensão entre hierarquia e igualitarismo que são característicos das sociedades rionegrinas e se expressam igualmente nas interações entre os diversos grupos sociais Baniwa. De modo similar, as Organizações Indígenas precisam lidar com as contradições inerentes aos processos hierarquizantes e equalizantes que perpassam suas linhas de atuação. Por um lado, sua trajetória é pautada pela lógica institucional de uma entidade oriunda do movimento social, centrada nas premissas da participação democrática pactuada entre cidadãos com direitos iguais; por outro lado, porém, a configuração determinada pelo parentesco se funda nas interações hierárquicas entre sibs, forçando as lideranças a atender simultaneamente às demandas de diferenciação hierarquizada dos grupos locais que lhes dão sustentação e ao ideário de representação democrática oriundo do movimento indígena.

Reunindo os dados obtidos com informantes do Içana àqueles disponíveis na literatura, foi possível configurar os conjuntos de sibs distribuídos atualmente entre Içana, Aiari e afluentes. As principais controvérsias que envolvem este tema estão ligadas à distribuição hierárquica de cada sib, visto que nem todos reconhecem o mesmo número de unidades de sibs que comporiam uma fratria, contestando principalmente sua posição no ranking da hierarquia, quando esta lhes é desfavorável.

Tomando como exemplo a composição da fratria Walipere, ${ }^{41}$ os sibs reconhecidos por informantes desta pesquisa são:

- Sib 1 - Koteroeni: sib cujas funções tradicionais estavam ligadas à obrigação de 'iniciar as coisas'; para os observadores externos, como os brancos, parecem ser os chefes principais porque são aqueles cujas ações têm maior visibilidade para os estranhos, mas internamente é o sib walipere dakenai que ocupa posição ritual mais prestigiosa; os mitos de origem situam os koteroeni como servos que 
precediam os sibs de 'irmãos mais velhos' e de 'irmãos do meio' na saída da cachoeira ancestral de onde os Walipere emergiram para a vida.

$\mathrm{Na}$ imagem antropomórfica que os informantes fazem de sua organização social, este sib corresponde à boca humana, sendo então uma de suas principais tarefas a de 'aconselhar' pessoas, procurar argumentos para as conduzir, induzir ou estimular à ação; boa parte dos capitães de prestígio no Médio Içana pertence a este sib. O conselheiro da Oibi no primeiro e segundo mandatos era um prestigiado capitão deste sib; o atual conselheiro da entidade é seu filho.

- Sib 2 - Neliwaieni: é um sib atualmente desaparecido que se classificava como o irmão mais velho entre os sibs que compõem esta fratria; na figura antropomórfica, corresponderia ao braço direito; dentre seus membros, eram recrutados os melhores guerreiros, caçadores e elementos que exercessem outras atividades manuais que exigissem força e destreza. Os informantes foram reticentes nos relatos referentes a este sib; um deles, um benzedor, recusou-se a falar sobre os membros deste grupo, alegando que eram 'pessoas más' que viviam para fazer a guerra e por isso foram extintos. Boa parte do espaço de prestígio deste grupo foi ocupado pelos membros do sib koteroeni nas relações políticas do Içana atual.

- Sib 3 - Maiakolieni: sua especialização ritual era de acendedores de cigarro, exercendo um tipo de mediação entre o material e o sagrado; eram encarregados de 'animar' as conversas nas festas e visitas. Sendo um sib de servos, também apoiavam os chefes da maloca na recepção dos visitantes, auxiliando-o para que nada lhes faltasse e para que assim a chefia pudesse se concentrar no desenvolvimento das fases deste ritual. Existem controvérsias sobre a que parte da figura humana que representa a fratria este sib estaria associado; para alguns informantes, ele estaria associado às mãos da figura humana, ao passo que para outros, aos olhos, já que seus membros também tinham a função de observadores, seja nos rituais, seja no território Walipere, suprindo os chefes de informações necessárias ao desempenho de seu papel político.

- Sib4 - Walipere dakenai: tradicionalmente, a função dos membros deste sib também era de conduzir processos, mas não no sentido físico, como o do sib koteroeni; os membros de walipere dakenai seriam tidos como estrategistas, analistas de situações, pensando e planejando para o tempo mais longo que o cotidiano; exerceriam também uma espécie de chefia moral, se obrigando a dar exemplo de conduta para os outros grupos. Na figura humana corresponderiam à parte pensante da cabeça; seriam os 'donos' do pensamento, dos juízos morais e estratégicos.

- Sib 5 - Tomiene: este sib equivaleria ao braço esquerdo da figura humana, sendo classificado como 'irmão menor' no ranking dos sibs desta fratria. Dentre suas funções rituais destacavam-se a de guardar a porta da maloca e de zelar pelo 
sono das pessoas, o que equivaleria, portanto, a fazer uma espécie de segurança interna. Suas atribuições não devem ser confundidas com a dos guerreiros, que eram encarregados da segurança nos arredores da maloca; os membros deste grupo eram encarregados de manter a ordem interna na maloca e, em caso de ataques inimigos, providenciar a evacuação segura de mulheres, crianças e outros membros não-guerreiros do grupo.

Existem poucos membros remanescentes deste sib, distribuídos entre comunidades do Rio Cuiari, em Vista Alegre e em São José, comunidade localizada pouco acima de Tunuí e moradia predominante dos Wadzarunai, um sib de antigos servos dos walipere dakenai, mas que não pertencem originalmente à fratria Walipere.

- Sib 6 - Toke dakenar: as pessoas entrevistadas não dispunham de informações nem sobre este sib, nem sobre o seguinte; apenas conseguiam informar que seus membros residem atualmente no Rio Guainia, na Colômbia.

- Sib 7 - Pirimiti dakenai e Tarewali dakenai: existe uma confusão até mesmo sobre a identificação deste sib; os informantes não conseguem distinguir se seria um sib com dois nomes ou dois grupos distintos.

(Fonte: informações coletadas por Bonifácio José Baniwa entre membros idosos do sib walipere dakenai).

Na representação dos Baniwa, a fratria Walipere corresponde à constelação das Plêiades e a disposição das estrelas no céu equivaleria à seguinte distribuição gráfica dos sibs:

Sib 6

(?)
Sib 7

(?)
Sib 2
(Braço direito)
Sib 4
(Cabeça)
Sib 1
Sib 3
(Boca)
(Máos? Olhos?)
Na hierarquia dos sibs a importância de cada um decresce nos pontos extremos da classificação; no caso Walipere, sibs n $\mathrm{n}^{\mathrm{es}}$ 1, 3, 6 e 7 são considerados sibs de servos; o mais valorizado é o irmão do meio ( $\operatorname{Sib} \mathrm{n}^{2} 4$, walipere dakenal), assim considerado porque sua posição conferiria equilíbrio à pessoa humana; é a partir deste atributo que se justificariam suas qualidades de mediador, negociador, estrategista e condutor de processos políticos; o segundo sib em importância dentre 
todos seria o de $n^{2} 2$, considerado o irmão mais velho; como este grupo está extinto, membros do sib koteroeni (Sib $\mathrm{n}^{2} 1$ ) passaram a pleitear esta posição social. A posição hierárquica dos sibs orientava, no passado, boa parte das funções e obrigações nas interações que travavam entre si; como se verá mais adiante, esta hierarquia ainda exerce um importante papel nas configurações assumidas pelo movimento indígena na área baniwa. A hierarquia interna de cada família é ordenada de forma diferente; nela a posição de primogênito recebe grande valorização ritual e social em virtude de sua condição de senioridade.

A posição proeminente de um sib ou de um membro da família não deve equivaler ao monopólio de bens nem a um poder de mando, devendo, ao contrário, resultar no estabelecimento de uma reciprocidade equilibrada, na qual aquele que ocupa uma posição mais destacada troca o prestígio outorgado pelos que estão em posição abaixo da sua por um pesado conjunto de obrigações redistributivas de bens materiais e simbólicos que favorecem a reprodução da vida social; assim se restaura o equilíbrio em relações fundadas na assimetria entre seus elementos constitutivos (Sahlins, 1983).

A distribuição hierárquica e nominação de sibs comporta, como já foi dito, uma série de controvérsias que tanto expressam as nuanças na apropriação das informações sobre a organização da sociedade, quanto as posições políticas que cada grupo social sustenta nas disputas que os membros dos sibs travam entre si. Em que pese a observação de Journet (1995) de que a hierarquia entre os sibs se refere a formas puramente protocolares de subordinação ou como referência às origens míticas comuns, os dados colhidos no Médio Içana mostram que a posição relativa de cada sib pode não gerar subordinação de uns em favor de outros, mas no contexto atual pode influenciar na obtenção de cargos e posições de prestígio na sociedade baniwa, o que pode ser traduzido também numa maior facilidade de acesso a recursos financeiros, representado, por exemplo, pelo salário.

Tal como em outros grupos rionegrinos, as relações entre as fratrias eram relativamente simétricas desde que a comparação fosse feita entre sibs de posição hierárquica similar, ou seja, um membro de sib hohodene ocupava lugar de prestígio equivalente a um walipere dakenai e assim sucessivamente. Alguns informantes reconhecem a existência, no passado, de uma certa especialização de papéis entre as fratrias, sendo relativamente comum as alianças entre Walipere e Dzawenai nas guerras contra os povos uaupesinos. Nessas alianças os membros da fratria Walipere, particularmente do sib walipere dakenai, eram considerados como melhores estrategistas, ao passo que membros da fratria Dzawenai seriam mais afeitos à execução física das ações guerreiras. Para esses informantes, não era infreqüente que os guerreiros Dzawenai seguissem sob as ordens de 'cabeças de guerra' (wapidzawall) Walipere. Além do chefe guerreiro ordinário (wapidzawali), os Baniwa reconhecem outro personagem, denominado watalikana, que seria um tipo de chefia 
moral, hierarquicamente superior ao wapidzawali, cuja origem e legitimidade seria construída a partir da guerra, mas que se perpetuaria em tempos de paz, passando inclusive a exercer influência supralocal, através do cultivo das qualidades morais valorizadas pelos Baniwa, tais como a honestidade, retidão de caráter e ponderação, além de habilidade verbal e capacidade de prever o futuro. $\mathrm{Na}$ interpretação evangélica de informantes Walipere, este personagem se configura com algo próximo aos profetas milenaristas baniwa. Como se verá posteriormente, a figura do wapidzawali é passível de uma atualização, mas ser watalikana pressupõe um estatuto moral cujo alcance não parece factível para os Baniwa dos dias de hoje.

\section{Guerra e alteridade}

Para Overing (1983/1984), a noção de alteridade está intimamente relacionada ao que seja entendido (e como seja exercido) como poder político e ao controle das forças da natureza para obtenção de produtos que garantam a subsistência. Suas idéias são centradas na noção de que a diferença é um princípio que viabiliza a existência da vida social, tornando-a possível por intermédio da conjunção de elementos distintos, que entre si interagem para formar o corpo social. É a alteridade e não a homogeneidade que funda a vida social; apesar disso, a diferença não deixa de ser associada ao perigo e à violência potencialmente disruptiva da vida social. A alteridade seria entendida, no pensamento ameríndio, como uma forma de variação (necessária) no conjunto de forças da cultura, o que é também uma forma de representar o poder. A sociedade se funda na possibilidade de partilhar o poder/saber dos diferentes, abrindo para eles uma potencial partilha dos bens culturais dos auto-referidos como iguais.

$\mathrm{Na}$ tradição oral baniwa, as interações conflituosas com a alteridade surgem como fundamento das relações sociais e um dos meios de garantia da reprodução de uma sociedade onde boa parte da inovação e da mudança social era buscada fora de suas fronteiras. Com efeito, os mitos demonstram à exaustão a incorporação de elementos enriquecedores da cultura através de ações belicosas traṿadas nos limites da sociabilidade. Nhiâpirikoli e seus irmãos travaram guerras sangrentas com tribos de animais ancestrais, por meio das quais foram obtendo os elementos fundantes da cultura e sociedade baniwa. A busca de elementos de constituição e renovação da cultura aparece nos mitos mediante o uso de:

- MEIos pacíficos: é o que ocorre no mito em que o irmão mais novo de Nhiãpirikoli busca e obtém Malikai, o poder mágico que possibilita o trabalho do xamã e do benzedor, com o gavião Kamathawa, um ser do grupo das aves, aliado permanente, no entanto, de Nhiápirikoli, aparecendo em muitos mitos como seu animal de 
estimação. O gavião teria sido criado a partir do coração de um dos assassinados irmãos do herói. Em outro mito de teor similar é o xamã Mawêno que obtém Malikai de Kamathawa e, em troca, torna-se seu genro. A obtenção de Moonotsi, isto é, de meios mágicos que permitem seduzir as mulheres também ocorre por doação; é o 'dono do Moonotsi', um ser não humano, que cede a planta e sua forma de preparo a Wadiokali, a fim de que este possa se tornar atraente para as mulheres. É por intermédio de Hoiniri, um espírito aliado, que Nhiâpirikoli obtém a zarabatana e a técnica de seu uso, o que lhe permite matar a serpente Omáwali.

- ROUBO, ENGANO E OUTRAS Formas DisfarÇADAS DE AGRESSIVIDADE: um dos mitos importantes com esta temática é do roubo, por Nhiâpirikoli, das frutas dos Yoopinai. O herói tinha criado as árvores, mas não sabia como frutificá-las. Sem saber como proceder para garantir a reprodução das árvores, Nhiãpirikoli rouba frutas maduras dos Yoopinai, desencadeando uma retaliação eterna destes seres, que, durante o período que vai de julho a setembro, costumam enviar temporais para castigar os Baniwa, beneficiários do roubo ancestral. Um dos mitos que conta a obtenção do fogo mostra uma sucessão de roubos: através de uma série de artimanhas, Nhiãpirikoli obtém o fogo de seu sogro Iwalífeli e o leva para casa; em seguida o jacaré Manulífeli rouba o fogo de Nhiãpirikoli e se retira para o fundo da água, deixando novamente o mundo sem fogo; o herói faz uma aliança com os sapos e engana o jacaré fazendo-o abrir a boca, o que lhe permite retomar o fogo de volta e o distribuir para a descendência humana.

O mito que narra a obtenção da pupunha envolve um conjunto de estratagemas para enganar e roubar Enúfeli, o dono da pupunha, mas já comporta uma série de violências e tentativas de assassinato entre os protagonistas, podendo ser classificado como uma transição para o grupo seguinte. Neste relato, Nhiãpirikoli tenta conseguir a fruta, mas Enúfeli se mostra bastante sovina - para os Baniwa um grave defeito de caráter -, negando-se a partilhá-la. Observando a movimentação das formigas, o herói consegue localizar o fruto e, ao comê-lo, sofre uma série de explosões primeiro na cabeça e depois no ânus. São tentativas disfarçadas de assassinato feitas por Enúfeli para evitar que Nhiãpirikoli se apossasse da pupunha. Finalmente, o herói obtém o fruto, mas só consegue plantá-lo através do recurso de engolir o caroço e semeá-lo ao defecar no solo.

- VIOLÊNCIA DIRETA, COMO GUERRAS OU ASSASSINATOS EM MENOR ESCALA: o mais significativo conjunto de mitos desta categoria é representado pelas guerras entre Nhiãpirikoli, com apoio de seus irmãos, e os macacos Eenunai. Essas narrativas se referem ao aparecimento e à disputa pelo controle do Manhene, o veneno que, para os Baniwa, constitui a principal causa de morte e desgraça para a humanidade. Entre as conseqüências destas ações violentas surgem a primeira morte no mundo, os benzimentos, as plantas medicinais e os cânticos para causar a morte, os Hinimai. 
Outros mitos relatam confrontos sangrentos entre Nhiâpirikolie seu sogro Kunáfeli, para vingar a morte de seu irmão, assassinado pela família de Kunáfeli; dentre as conseqüências destes enfrentamentos surgem o timbó e a malária.

Um longo mito narra a morte de Kuwaikanili, que nesta narrativa representa simultaneamente Nhiãpirikoli e seu irmão, engolido pela serpente Unidáfeli, que desce o Rio Negro. No ventre putrefato do animal, Kuwaikanili percorre um doloroso caminho de doença que leva progressivamente à morte, do qual só se desvia quando ele consegue matá-la. Da narrativa depreende-se o surgimento de uma série de cânticos de cura, de regras dietéticas adequadas para doentes graves e do uso de plantas diversas para fins eméticos, curativos e como armas para enganar a serpente. Do corpo podre do animal morto surgem larvas com as quais Nhiãpirikoli criará os precursores dos homens brancos e negros, cuja condição plenamente humana só será obtida quando os retirar da cachoeira de Hipana. Neste mito, a condição de alteridade do branco é enfatizada por se originar do tapuru retirado do corpo de Unidáfeli.

Outros relatos enfatizam a condição de alteridade do branco, ao registrálo como uma das identidades de Omáwali, que se transforma em homem branco para manter relações sexuais com a mulher de Nhiãpirikoli. Também Kowai-embora filho de Nhiãpirikoli representa a alteridade ambígua, simultaneamente ameaçadora e construtora do mundo, mas tão estranha e perigosa que é proibida de conviver no mesmo espaço com os proto-humanos ancestrais dos Baniwa - aparece com freqüência na identidade de um branco. Por sua vez as mulheres, quer sejam representadas pelas inúmeras esposas de Nhiãpirikoli, filhas de tribos hostis, ${ }^{42}$ quer pela primeira mulher Amaro, que tem relação direta com os brancos e suas mercadorias, são consideradas elementos fronteiriços entre a sociedade baniwa e a alteridade hostil.

Entre os principais pontos comuns a estes três grupos de relatos míticos podemos identificar o pressuposto nativo de que a obtenção amigável de novos poderes e saberes se dá principalmente na consangüinidade, no interior de sua própria sociedade, onde é possível praticar a reciprocidade generalizada, algumas vezes reafirmada por um contrato de casamento entre aliados confiáveis, mesmo não sendo consangüíneos. À medida que as alianças vão se distanciando do centro da sociabilidade baniwa, elas começam a comportar fraudes, enganos e violência latente; geram um tipo de reciprocidade equilibrada, mas cercada de desconfiança e marcada por uma estrita vigilância para evitar ou limitar a possibilidade de que um dos membros da relação leve vantagem sem nada oferecer em troca, tal como se observa no grupo intermediário de mitos.

A violência explode franca no terceiro conjunto de mitos, no qual Nhiãpirikoli se esforça em estabelecer uma vida social fundada na troca e na aliança 
com grupos hostis, que tenta pacificar sem muito sucesso pelo estabelecimento de relações matrimoniais. É um terreno fértil para a aquisição de inúmeros saberes e poderes que ordenarão o futuro mundo baniwa, mas obtidos por meio da reciprocidade negativa representada pelo assassinato, por um ciclo interminável de vinganças, pelo surgimento de doenças e da morte e por uma desconfiança permanente dos não parentes, que até hoje perpassa as interações na sociedade baniwa.

As relações com a alteridade representada pelos afins agressivos constituem-se um dos elementos centrais da cosmologia baniwa, na qual se demonstra que a violência tende a crescer proporcionalmente ao distanciamento das relações de consangüinidade entre os personagens que interagem entre si. Os afins preferenciais representam um elemento intermediário neste cenário; são grupos com quem se trava aliança, mesmo sem uma confiança plena em suas ações e propósitos.

A irrupção da figura poderosa do branco na condução de um violento processo colonizatório leva ao seu enquadramento como um caso particular de alteridade, expresso por sua inserção no panteão dos seres mais agressivos e perigosos do imaginário baniwa, como atestam os relatos míticos que tratam da questão. A necessidade de controlar a periculosidade deste estranho especial gera a produção de mediadores (capitães, lideranças de Organização Indígena, agentes indígenas de saúde, professores) do contato interétnico, que, por meio de alianças/ oposições políticas, religiosas, econômicas e de compadrio, buscam integrar seus poderes e saberes ao sistema indígena de mundo (Sahlins, 1988).

No caso baniwa, existem íntimas relações entre guerra e alteridade. Wright (1981) e Journet (1995) caracterizam a atividade guerreira como elemento estrutural da sociedade baniwa, no qual os jovens combatentes são momentaneamente autorizados a traspassar as fronteiras da sociedade, das regras morais e a hierarquia de gerações, para encetar a obtenção de bens simbólicos (vingança, controle sobre o 'sopro vital' dos inimigos mortos, rapto de crianças como meio de substituição dos mortos do grupo etc.) que potencializam as possibilidades de reprodução da sociedade.

Para Journet (1995), a guerra é uma modalidade de poder político que emerge em situações de ruptura do cotidiano; o chefe guerreiro é a outra face da chefia ordinária de aldeia, cujas atribuições aparentemente opostas de mediar e contemporizar são de fato a contraparte do papel do wapidzawali, o protagonista principal da ação guerreira, aquele que precede e coordena os guerreiros, não sendo necessariamente o autor físico das ações, particularmente do assassinato dos inimigos. As estratégias de mediação e busca de consenso utilizadas pelo chefe da aldeia não seriam qualitativamente distintas das estratégias usadas pelo cabeça de guerra para obter a coesão de seus guerreiros, igualmente ligados a ele pelos laços de consangüinidade e/ou afinidade real. 
Para Wright (1999a), a guerra é um evento associado aos planos mais externos da alteridade. Os conflitos intra ou interclânicos, uso de Manhene e outras formas de agressões entre parentes e/ou afins pertencentes ao mundo baniwa não costumam receber a denominação de oowi, que é reservada para as grandes mobilizações coletivas contra não-membros do mundo baniwa; a guerra costuma ser feita contra 'outra gente', que 'vive longe', contra grupos lingüisticamente distintos, que podem ser afins potenciais, mas preferencialmente pertencentes a outras culturas.

As relações guerreiras expressam também relações de reciprocidade entre os contendores, adotando a forma de reciprocidade negativa, já nos limites da sociabilidade, entre os inimigos que se enfrentam, e reciprocidade generalizada no interior de cada grupo combatente. Em função disso, o desfecho da guerra não implica reequilíbrio nas relações entre os combatentes. Uma vez desencadeado, o ciclo de vinganças recíprocas só se esgota quando um dos lados fica impossibilitado de reagir; neste caso, o restabelecimento da paz se dá por um aprofundamento da assimetria entre os dois lados em conflito e não por uma retomada do equilíbrio; a paz se faria possível apenas pelo aniquilamento de um dos grupos; isso não ocorrendo, a tendência seria o estabelecimento de um estado perpétuo de hostilidade aberta ou latente.

As práticas guerreiras são o oposto simétrico das trocas matrimoniais, ambas se configurando como meios centrais de reprodução da sociedade. Elas buscam a re-organização interna do grupo mediante relacionamentos travados fora de suas fronteiras. A diferença essencial é que as relações guerreiras se fundam em relações de reciprocidade negativa, travadas nas fronteiras da sociedade e as trocas matrimoniais se caracterizam por trocas equilibradas realizadas na fronteira da consangüinidade, mas as duas pressupõem a celebração de alianças que favoreçam a incorporação do 'outro' como forma de autoconstrução.

Os elementos contidos na análise da alteridade e da guerra permitem estender esta caracterização para as interações travadas com o branco, cuja condição de um caso específico de alteridade é demonstrável em mitos já citados, nos relatos de guerra registrados por Wright (1981, 1999a), na diferença lingüística, na ausência de trocas matrimoniais e predominância de relações marcadas pela violência de uma reciprocidade negativa exercida em favor do branco.

Dada a concepção baniwa de guerra, pode-se considerar que os combates abertos entre os membros dessa cultura e os brancos foram encerrados pela absoluta desigualdade de forças; a hostilidade persistente foi deslocada para outras formas de expressão, que têm se exteriorizado ao longo do contato através de sua espetacular adesão às propostas de profetas messiânicos que pregam um afastamento radical do mundo dos brancos e pela ação empreendida pelos Baniwa contra empresas mineradoras de ouro que invadiam sua área na década de 80 (Wright, 1992d, 1999a). 
Paralelamente a isso, a assimetria do contato interétnico retirou dos Baniwa parte da capacidade de garantir sua reprodução social. O controle que eles são capazes de exercer sobre as forças da natureza garante apenas parcialmente sua subsistência, boa parte da qual depende hoje da aquisição de mercadorias industrializadas e de serviços como a educação e os cuidados de biomedicina, que tampouco são passíveis de uma produção autóctone. A intervenção colonizadora instaura um tipo de dominação que impossibilita a existência de sociedades completamente autônomas; no mundo atual, parte significativa de sua capacidade produtiva tem que ser buscada no mundo não-indígena, o que gera a necessidade de mediadores especializados no contato interétnico, cuja missão visa à transposição das fronteiras da etnicidade em busca de saberes/poderes dos brancos que possam integrar elementos da sociedade mundial no sistema de vida baniwa, viabilizando a existência das gerações futuras (Sahlins, 1988).

$\mathrm{Na}$ cultura baniwa a aquisição de conhecimento e a relação com a alteridade são componentes indissociáveis da vida social; ambos exigem autocontrole e capacidade de negociação para que se obtenha os meios para uma fundamentação adequada da vida social. Conhecimento e alteridade são associados ao perigo e à violência potencial, mas também à obtenção de saberes necessários à reprodução da sociedade, desde que utilizados de forma ética. Neste contexto, a "economia política das pessoas" reproduz o padrão ancestral de transposição de fronteiras em busca da satisfação de necessidades inerentes ao equilíbrio interno do grupo, o que antes se fazia pela guerra ou pelo comércio entre iguais.

Se outrora os jovens guerreiros serviam às chefias mais velhas que os enviavam para os raids de guerra, mantendo a si próprios como coordenadores/ mentores da ação guerreira, hoje líderes de Organização Indígena, professores e agentes de saúde também se colocam a serviço das chefias mais velhas numa guerra de papel e caneta travada no violento aparato institucional de dominação, um espaço externo às relações de parentesco, nas quais predominam relações de reciprocidade negativa que eles buscam inverter ou amenizar por meio de estratégias de tipo simbólico.

No espaço das relações interétnicas, a atuação das lideranças pode ser considerada uma atualização das relações guerreiras com uma alteridade perigosa e potencialmente destrutiva. Uma das características mais valorizadas na atuação de lideranças é 'a coragem de enfrentar os brancos' e fazer valer suas posições. Assembléias indígenas são momentos privilegiados para se 'falar duro' com os brancos. A presença de autoridades não-indígenas e, até mesmo, de aliados do dia-a-dia, como os assessores, reveste-se sempre de um componente de tensão. Dependendo da temática discutida e do clima emocional criado, antigos rancores podem ser atualizados e a presença minoritária de não-índios pode se tornar um meio de lideranças emergentes demonstrarem sua bravura. Aqui, as armas usadas 
são os documentos, as denúncias e a ocupação dos espaços de participação social onde lutam para fazer valer as idéias de cidadania e democracia vagamente acenadas pelos brancos. As regras gerais de interação com a alteridade, expressas em mitos já analisados, também incidem sobre o aprendizado dos saberes dos brancos, pelas lideranças de Organização de Base. Se as guerras físicas foram abolidas, atualmente os embates na Foirn, nas negociações com os militares, com a prefeitura e com os órgãos de governo em geral tomaram seu lugar e os jovens líderes são a linha de frente desses confrontos travados com a alteridade.

Os brancos representam simultaneamente a violência, a morte, a riqueza e o prestígio; tal periculosidade gera a necessidade de um controle estrito dos aspectos da vida que a eles se relacionam, não se isentando disso as próprias lideranças indígenas que efetuam a mediação entre os dois mundos. A singularidade dessa interação faz com que as chefias de aldeia e de base estabeleçam relações permanentes de tensão entre eles e seus potenciais inimigos, uma categoria que pode congregar não apenas outros grupos étnicos, mas o próprio Estado brasileiro, instituições da sociedade nacional e inclusive assessores não-índios que trabalham com o movimento indígena. A mediação feita pelas lideranças indígenas deve ser entendida como uma guerra permanente, hoje travada no campo simbólico dos poderes/saberes do branco, mas análoga à guerra de Malikai travada por Nhiãpirikoli e seus irmãos, contra macacos, serpentes e outros seres espíritos da ancestralidade.

A condição liminar dos mediadores do contato interétnico pode torná-los objeto de temor e desconfiança, num mecanismo tipo contigüidade, no qual a proximidade excessiva os torna susceptíveis de transformação no próprio inimigo. A cobiça, a avareza e o proveito individual do conhecimento aí adquirido são transgressões das normas de generosidade e reciprocidade que orientam a vida social e ameaçam a instauração do caos.

Tais atitudes são passíveis de punição pelo corpo social na forma de envenenamento, sopro, ostracismo político, perda de credibilidade e de votos para mandatos futuros. Mesmo nos dias de hoje, a perpetuação da ordem social exige um gerenciamento responsável do conhecimento e do poder adquirido na fronteira interétnica. Os sujeitos empenhados em sua aquisição são responsáveis por seu uso ético, mas não ficam entregues a si próprios, sendo permanentemente monitorados pelo corpo social.

\section{Poder político e chefia indígena}

Santos-Granero (1990, 1993), problematiza as características da chefia indígena das terras baixas sul-americanas e o exercício de poder político no âmbito dessas sociedades. Trabalhando com idéias desenvolvidas por Clastres (1982, 1990), 
ele aponta os limites da abordagem deste último, mas não contesta a validade da afirmação deste autor de que as relações políticas nessas sociedades se configuram como uma relação de troca de bens e palavras entre líderes e seguidores. Por meio de estudos de caso de diversas sociedades ameríndias, ele confirma que a relação de simetria entre chefes e liderados, a ausência de poder de mando da chefia indígena, a distribuição generosa de bens e o exercício do poder mediante a capacidade de convencimento pelo uso eloqüente da palavra utilizada como via de negociação e pacificação de conflito entre os liderados, são características básicas das chefias indígenas sul-americanas.

Outro elemento típico no desempenho desses líderes é atuar no que ele chama de "esfera das relações diplomáticas", isto é, na recepção cerimonial de visitantes e no estabelecimento de interações formais de alianças e negociações com outros chefes. Para Santos-Granero, a atividade política seria uma forma de relação social baseada em trocas recíprocas mediadas pelo manejo do discurso. Com freqüência, os líderes políticos indígenas fundam seu poder político no consenso obtido através do domínio de saberes simbólico-rituais, que os habilitam a agregar esforços produtivos dos membros de suas comunidades, mas sem exercer, necessariamente, um controle sobre a produção econômica e/ou sobre as formas de apropriação de tais bens.

O controle dos processos rituais, propiciando a intervenção mística dos líderes nos processos produtivos e reprodutivos, se configura como um bem escasso que representa uma das principais fontes da autoridade política e econômica em tais sociedades; assim, nenhum poder se configura como exclusivamente político ou econômico (Santos-Granero, 1990:659). O autor lembra, porém, que nem sempre o domínio dos meios rituais de poder implica obrigatoriamente poder político, já que nem todos os líderes místicos são líderes políticos; entretanto, em tais grupos não se costuma encontrar líder político destituído de poderes simbólicos nãoderivados do poder econômico.

Uma das distinções básicas do exercício de poder nas sociedades em questão é que o montante de poder distribuído pela maioria dos membros do corpo social é bem mais amplo que aquele disponibilizado para os grupos sociais que experimentam a dominação econômica nas sociedades com Estado. Além disso, o exercício descentralizado do poder, feito nos interstícios da sociedade por intermédio de instituições que se distribuem em inumeráveis pontos de interação social, dificulta o monopólio pelos dirigentes e favorece a manutenção de mecanismos sociais de redistribuição de poder e bens, mesmo em contextos de relações assimétricas entre dirigentes e o restante do corpo social (Santos-Granero, 1990).

A análise das relações internas que na cultura baniwa fundam e sustentam o exercício do poder político mostra que as relações estabelecidas entre chefias indígenas e membros das comunidades seguem, em termos gerais, os parâmetros 
de orientação traçados na discussão teórica que enunciamos. As interações entre lideranças de Organizações Indígenas e suas bases são igualmente configuradas num sistema de reciprocidades no qual as primeiras trocam o ingresso de bens e serviços no meio comunal por prestígio e legitimidade que lhes garantem os mandatos, seguindo o que Sahlins (1983:207) caracteriza como um tipo de simetria social, na qual se estabelecem relações solidárias, com benefícios e assistência mútuos, se caracterizando como um centro onde se agregam bens materiais e simbólicos, que a partir daí fluem em direção à periferia da sociedade.

Esse princípio se aplica a diversas formas de interação entre lideranças de Organização Indígena e chefias de aldeias, como, por exemplo, as regras de cortesia praticadas nas viagens de articulação: quando a liderança chega na aldeia, costuma ser recebida com alimentos e oferece em troca informações e notícias sobre os mais recentes acontecimentos em São Gabriel e nas aldeias em que passou, sobre a atuação da entidade etc. De modo análogo à expectativa gerada em torno da chefia ameríndia, a liderança de Organização Indígena é vista como um especialista na mediação das relações interétnicas de quem se espera uma distribuição regular de bens, materiais e simbólicos, particularmente aqueles oriundos do mundo dos brancos, sob pena de ver seu prestígio esvanecer-se.

Sahlins (1983) estabelece ainda conexões entre reciprocidade, distância/ proximidade de parentesco e distância/proximidade espacial entre os parceiros das relações de troca, demonstrando que relações de reciprocidade generalizada estão diretamente correlacionadas com interações estabelecidas entre consangüíneos e são diretamente proporcionais à distância geográfica de moradia. Nesta linha de análise a categoria de 'não parente ${ }^{43}$ representa a reciprocidade negativa por excelência, aqueles aos quais não se devem obrigações e com os quais se deseja obter ganhos sem obrigação de retribuição.

Ele representa o plano tribal como uma série de setores residenciais concêntricos, mais ou menos inclusivos, onde se dispõem os grupos de parentes, e observa que o caráter da reciprocidade varia de acordo com sua posição no espaço geopolítico. A tendência geral identificada por ele seria a predominância da reciprocidade irrestrita entre os parentes mais próximos, que também são os que costumam residir mais perto. $\mathrm{O}$ aumento da distância de parentesco costuma acompanhar o distanciamento espacial das moradias, dificultando o estabelecimento de relações harmônicas de reciprocidade. Mesmo na vigência de consangüinidade entre residentes espacialmente distantes, esta última variável costuma subordinar a primeira, limitando igualmente a prática da reciprocidade positiva (Sahlins, 1983:216).

O autor estende essa análise ao entendimento das relações de moralidade, mostrando que elas seguem lógica similar à das relações de reciprocidade, sendo de tipo situacional e variando em função da proximidade geográfica e de parentesco 
entre os que interagem. Desta forma, certos atos, quando praticados em relação a consangüíneos, podem ser condenados, mas são aprovados quando praticados em relação a não-parentes: "um ato não é bom ou mau em si mesmo, sua classificação dependerá de quem seja o outro" (Sahlins, 1983:218).

Rivière (1984) também corrobora diversas características da chefia indígena previamente citadas, tais como a generosidade e a capacidade de persuasão, condições fundantes de sua possibilidade de exercer influência política no grupo de parentes e/ou de afins que se propõe a representar. Outros fatores como co-residência e a expectativa social de que o chefe tome a iniciativa diante de situações que exijam um esforço coletivo são também elementos viabilizadores do exercício da chefia. À luz dessas considerações, é possível perceber que as relações de reciprocidade que dão suporte ao trabalho de chefatura se assentam num esquema tripartite de tipo moral, social e econômico.

Os atributos descritos para a chefia de aldeia se reproduzem nas formas de interação dos líderes de Organização Indígena com as aldeias de sua área de atuação. Tais relações, que num primeiro plano parecem ser de tipo prioritariamente econômico, envolvendo desenvolvimento de projetos, captação de bens, geração de renda etc., centram sua possibilidade de existência e atuação nas relações travadas no âmbito do parentesco, guardando obrigações morais, que, como já foi dito, são contextuais, sendo mais estritas quando aplicadas a consangüíneos e coresidentes. Igualmente, proximidade e distância geográfica entre as aldeias de origem dos membros da diretoria da entidade e o conjunto total de aldeias por eles representadas são elementos essenciais para um maior ou menor aporte de apoio política à sua atuação.

Estas formulações possibilitam a problematização das características do poder político exercido pelas Organizações Indígenas Baniwa e das interações com o conjunto de produções simbólicas e materiais que constituem sua cultura. Para a presente análise, faz-se necessário examinar detidamente um poder político que é centrado na hierarquia de gerações, na qual os mais velhos dominam saberes rituais cujo produto deve ser redistribuído entre os membros do corpo social, e no exercício de um tipo de chefia que se configura nos moldes que descrevemos. Também se deve buscar $\odot$ entendimento de como essas formas de poder se configuram nas condições atuais de vida baniwa, seja entre as chefias de aldeia, seja entre as lideranças de Organização Indígena, que manejam saberes simbólicos oriundos do mundo não-indígena potencialmente capazes de gerar assimetria e dominação de tipo econômico.

Na cultura baniwa a chefia de aldeia exerce um papel destacado nas interações com a alteridade, o que a torna alvo de uma série de controles exercidos pelo corpo social que visam limitar os perigos inerentes a esta função. É responsável por zelar pela manutenção das fronteiras entre as comunidades e/ou sibs, sua 
autoridade demarca o espaço do 'nós', separando-o do espaço do 'outro'. Neste sentido, a função das lideranças de Organização Indígena é similar, só que operando no plano das relações interétnicas, no qual estão encarregados de transpor as fronteiras estabelecidas com um tipo particular de 'alter'. Seu principal papel não é manter essas fronteiras, e sim transcendê-las de forma controlada, atuando como um tipo de sentinela avançada, cuja ação, se bem-sucedida, pode contribuir para obtenção dos necessários saberes vindos do mundo externo ao cosmos indígena, mas sem colocá-lo em risco.

A análise dos atributos considerados ideais na atuação de um capitão evidencia importantes categorias nativas que regem o estabelecimento de um modelo adequado de chefia; tais parâmetros parecem vir se estendendo à atuação das lideranças que militam nas Organizações Indígenas. O modelo instituído para a chefia da aldeia propicia um padrão de comparação que permite o monitoramento contínuo não só do desempenho das jovens lideranças, como também das chefias de instituições do mundo dos brancos; a atuação destes últimos também é continuamente avaliada quanto à maior ou menor congruência com os parâmetros de comportamentos socialmente valorizados segundo o ethos baniwa.

No passado, as atribuições de uma chefia de maloca baniwa se orientavam para a articulação política de relações interlocais, objetivando estabelecer alianças guerreiras, organizar rituais (pudali) de dança e trocas cerimoniais e receber visitantes. No plano intralocal preocupava-se com o ordenamento do cotidiano na maloca, onde se esperava que o mesmo fosse capaz de liderar situações do dia-adia, emitindo juízos serenos sobre a melhor forma de organizar os trabalhos de interesse comum e mediar conflitos, buscando sempre o consenso.

Transcreveremos a seguir três depoimentos de informantes baniwa, os quais foram selecionados de forma a enfatizar as distintas atribuições da chefia, que acabamos de discutir:

Pra ser um bom chefe era assim: ficar nas comunidades, receber qualquer pessoa que chega e, tendo alguma coisa, dar de comer ou então dar de beber; também era ver nas comunidades, ao redor da comunidade, o que falta, o que está errado, o que não está como ele quer. Aí, se ele convida alguém [para fazer um mutirão], ele entáo tem que dar de comer, que não pode trabalhar assim com fome; ele consegue um peixe, junta as pessoas e come um tucunaré, toma um chibezinho e pronto. Depois ele fala pro povo: agora nesse dia nós vamos fazer a limpeza da nossa comunidade, porque está muito cerrado, muito feio, capaz de cobra sair de lá e as crianças andam pelo cerrado; é capaz de cobra morder; se morder, o culpado somos nós mesmos que não limpamos...(G. M., capitão Walipere)

Os parâmetros orientadores da ação da chefia são perfeitamente congruentes com as características da chefia ameríndia descritas nas contribuições 
teóricas de Clastres e Santos-Granero, citadas ao longo do capítulo e que permanecem definindo, ainda hoje, os critérios baniwa de avaliação do trabalho de capitão, tais como:

- O COMPORTAMENTO MORAL:

É como eu falei antes, é igual pra capitão; primeiro é responsabilidade, a moral, o comportamento correto, a paciência com as pessoas, depois é que vem o trabalho; primeiro é o comportamento da pessoa que influencia muito; o trabalho já é conseqüência, quem tem bom comportamento aí já faz um bom trabalho mesmo. É isso que faz ele ser respeitado, quer dizer, legítimo como você diz. (B. J., liderança evangélica Baniwa)

- A SENIORIDADE E.A GENEROSIDADE:

Os antepassados usavam isso de ser capitão até uma pessoa morrer; eles não ficavam trocando não; o capitão era aquele mais velho, aquele que levantou a maloca, que organizou aquele povo para morar no lugar; ele era a 'cabeça', aquele que pensa e orienta o povo pela palavra.... Aí, se ele faleceu e tiver irmão dele, um pouco mais novo, bota o irmão, se não tiver, o filho mais velho do finado continua depois do pai, vai manejar o povo; mas não pode ser muito novo porque a nossa história diz que é o idoso que já tem uma idéia melhor pra levar a vida de viver; o moço ainda não é assim completo, o pensamento dele é leve, não tem idéia muito boa pra assumir esse cargo, fala besteira e fica no atoleiro...Capitão também tem que ser bom pro povo; se ele tem comida, assim comida grande, peixe, caça, porco, a anta, essas coisas, ele tem que arrumar cozinheira e chamar o povo pra comer; aí ele diz: vamos que nosso irmão matou alguma caça, algum peixe, vamos comer assim. E assim é... (R. P., vice-capitão Dzawenal)

No mundo baniwa, uma das principais atribuições do capitão permanece sendo a mediação de conflitos. Numa sociedade em que não existe nenhum tipo de força central de coação dos indivíduos, o confronto agudo entre seus membros costuma gerar cisão no grupo; para evitar tais extremos, a principal estratégia utilizada é a busca cotidiana de acordos entre os membros da sociedade. No processo de contínuo apaziguamento de conflitos, a chefia de aldeia é a figura essencial para o exercício desta atividade (Sahlins, 1983). O controle dos potenciais conflitos internos do grupo é uma tarefa delegada para o capitão, entre cujas funções essenciais está a de negociar e obter acordos entre partes em litígio, mas sem impor sua vontade, já que não dispõe de poderes para tanto. Na realidade observada, quando o capitão se envolve em uma disputa pelo poder com outro membro da aldeia, o resultado final da contenda costuma ser o afastamento de 
ambos os litigantes dos espaços de poder; a destituição do chefe é decorrente de sua falha em mediar as tensões intragrupo. Este tipo de expectativa social se estende também à liderança de Organização Indígena, que é avaliada pelos mesmos parâmetros usados para a chefia de aldeia.

Journet (1995) assinala que um dos termos baniwa utilizados para designar o capitão é enawe, que significa 'aquele que mantém sua palavra'. De fato, a constância de opiniões e de firmeza de posições é um atributo valorizado no trabalho da chefia, em um grupo que aprecia a serenidade, a ponderação e a persistência. Mudanças de opinião e de posicionamento na cena social são consideradas como indicadores de imaturidade e inadequação ao exercício do poder político; tais valores têm forte influência na avaliação negativa que os Baniwa fazem da atuação das instituições dos brancos, aí se incluindo a da missão católica, ${ }^{44}$ notoriamente instáveis e contraditórias nas suas políticas de ação.

A língua baniwa dispõe de um conjunto de palavras aplicáveis à avaliação do desempenho de lideranças, que configuram um mosaico onde se expressam as características de um grande chefe e se definem os valores morais que orientam a ação política nessa cultura.

O primeiro desses termos a ser analisado é Likoada, a lei da reciprocidade, um elemento fundamental na vida social. O vocábulo já foi utilizado antes, na análise das relações guerreiras e da produção de doença, e é retomado aqui para expressar a doutrina baniwa de que tudo o que uma pessoa faça, para o bem e para o mal, retorna a ela.

Wright (1992a) e Journet (1995) têm usado o vocábulo para analisar as relações guerreiras, concebidas como uma forma de 'retorno' da agressão, enquadrando-a, portanto, no contexto da reciprocidade. Aqui, ampliaremos mais ainda a noção de Likoada, situando-a como uma forma de expressão muito ampla da reciprocidade, que atinge os mais diversos setores da vida humana e fornece a base de toda vida política. A própria humanidade só pode ser pensada no âmbito das relações de reciprocidade positiva e negativa, visto que a capacidade de estabelecer trocas é um dos fundamentos da condição humana. Em decorrência deste alcance tão alargado, o termo pode ser utilizado também para explicar a origem das doenças e/ou infortúnios que incidem sobre o grupo. As doenças costumam ser concebidas como 'troco', retorno de alguma ação moralmente condenável e/ou medidas de aprimoramento pessoal que deixaram de ser feitas. Também a obediência às normas dietéticas, de higiene, de boa convivência social e de seguimento dos rituais de prevenção de doenças é vista como a contrapartida da saúde.

As relações cósmicas e sociais são concebidas como uma via de mão dupla, orientada pela noção de reciprocidade. Todos devem pautar suas ações pela idéia de que, se servir a alguém, futuramente será servido; se partilhar bens e favores, receberá em troca a mesma gentileza. Da mesma forma, quem enviar veneno, 
sopros ou outros malefícios quaisquer, receberá de volta o mau conteúdo de suas ações. Nenhuma esfera da vida e do comportamento deixa de ser perpassada pela noção de reciprocidade, que coexiste com a tensão gerada pelo comportamento censurado, mas real, daqueles que tentam receber sem retribuir, instaurando as formas de reciprocidade negativa.

O exercício da chefia é também uma expressão do 'retorno' ou 'troco' - a tradução em português usada pelos informantes para a palavra Likoada - o chefe distribui comida, gentilezas, compreensão, esforço no apaziguamento de conflitos e recebe em troca legitimidade e prestígio para exercer sua função; esse raciocínio se estende integralmente ao trabalho de Organização Indígena: de modo análogo os membros das aldeias oferecem votos, mandatos e apoio político para lideranças jovens e inexperientes e esperam em troca que a Organização Indígena obtenha, entre os brancos e com a Foirn, bens, serviços e prestígio político para usufruto de todos.

As relações hierárquicas entre os sibs são variáveis importantes no estabelecimento de compromissos e obrigações de reciprocidade, que também incorporam conotações morais e econômicas. As relações travadas entre os sibs situados acima e abaixo na hierarquia ritual baniwa não diferem do padrão já descrito na literatura para as chefaturas sul-americanas (Clastres, 1990), (SantosGranero, 1993). Neste caso, observa-se o estabelecimento de pressões sociais para que o tipo de troca adotado seja o de reciprocidade generalizada, na qual o chefe deve doar bens de forma irrestrita aos sibs subordinados.

Formas similares de interação também costumam matizar as hierarquias estabelecidas entre gerações, o que é congruente com as regras que regulam o exercício do poder político; em geral, os cargos costumam ser ocupados por pessoas mais velhas, pois a tendência é de que o homem mais velho de um grupo de irmãos - devendo o termo 'mais velho' ser aqui entendido tanto no sentido da ordem biológica de nascimento dos filhos de uma família como da ordem de senioridade dos ancestrais míticos, que se expressa no status dos sibs -, ocupe prioritariamente os cargos de chefia.

Os dados coletados para as Organizações Indígenas confirmam a tendência de que os irmãos mais velhos preferencialmente concorram aos cargos majoritários antes de seuś irmãos mais jovens; igualmente as lideranças de Organização Indígena costumam ser eleitas entre membros de sibs considerados superiores na hierarquia ritual, observando-se a manutenção da integridade lógica do modelo de chefia e das obrigações de reciprocidade irrestrita daí decorrentes. Tal situação força a liderança a um esforço contínuo para atender aos pedidos de suas bases de apoio político e a viver sob ameaça constante de deposição, difamação e envenenamento (Manhene), caso se mostre incapaz de satisfazer às demandas de seu grupo de parentes. Como cada conquista gera simultaneamente prestígio e novas demandas, a trajetória da liderança passa a comportar uma espiral de exigências crescentes 
de generosidade redistributiva (kaponidall), cujo não cumprimento costuma redundar em seu desprestígio e queda, num processo que lembra o infortúnio do guerreiro selvagem, tão bem descrito por Clastres (1982).

Os Baniwa dispõem de outros termos que expressam o comportamento ético e desejável numa liderança, tais como Madzakanidali, que seria 'uma pessoa direita', ou seja, alguém que cumpre seus compromissos e obrigações; aquela com a qual se pode contar, que cumprirá um acordo firmado; Ithanhetakhetti, pessoa respeitosa, que procura ser gentil e educada com os mais velhos; Itarawatakhetti designa a capacidade de autocontrole e Newikhiadali expressa idéia de moderação de atitudes; pessoa ponderada cuja ação foge a extremos etc.

Tais conceitos não são apenas abstrações; eles podem ser evidenciados no cotidiano político das aldeias. A observação participante de assembléias indígenas permite ver a deferência com que as lideranças procuram tratar os mais velhos e o seu esforço em se mostrar firmes, convincentes e autocontroladas. A expressão aberta de raiva, tristeza ou frustração é cuidadosamente evitada e a alegria e afabilidade cultivadas; o rigoroso controle sobre a externalização de sentimentos íntimos torna difícil para um observador externo decifrar as expressões faciais ou corporais de seus interlocutores. A facilidade de falar em público e a capacidade de fazer uma platéia rir em reuniões e assembléias são habilidades valorizadas; em geral velhos capitães, benzedores e narradores de mitos manejam com muita eficiência a capacidade de prender a atenção de uma platéia, alternando a discussão de assuntos sérios com a emissão de ditos jocosos que fazem os presentes gargalhar. Também é atributo da liderança a habilidade em manter a paciência, não se deixando levar por provocações fundadas ou infundadas. A capacidade de negociar e transitar entre as várias facções que dividem os grupos de parentesco são qualidades essenciais de um líder, que precisa garantir o apoio político de várias famílias para desempenhar suas tarefas a contento, mediando e conciliando conflitos.

Gestos e posições extremadas podem ser explicitamente censurados e esta censura não se restringe aos interlocutores indígenas; brancos que expressam posições extremistas também não são apreciados, podendo haver uma atitude sub-reptícia de evitar o contato com os mesmos. Outros atributos valorizados nas chefias são o respeito às regras da moral doméstica, tais como o repúdio às relações extraconjugais (particularmente em se tratando de relacionamentos de homens casados com moças solteiras), o exercício da paciência e da gentileza com a esposa e os filhos, a diligência em prover o alimento para a família e para a refeição comunal.

A obediência às normas sociais, o cumprimento rigoroso da palavra empenhada e o culto à verdade são atitudes menos propaladas e mais demonstradas; as lideranças se esforçam em convencer seus interlocutores da excelência de seu comportamento, mais através de atos do que de palavras, pois a autopromoção é igualmente rejeitada no mundo baniwa. A prática de tais habilidades só se faz 
possível mediante o cultivo cotidiano da autodisciplina, outra virtude muito apreciada no código moral baniwa. Ritos de passagem, cuidados de higiene e saúde, a dietética, a organização da vida e dos ritmos de trabalho diário são estratégias correntes de aprimoramento da disciplina pessoal, que se espraiam pelo conjunto da vida social.

No capítulo anterior, foi possível explorar a importância da disciplina e do autocontrole na manutenção de uma vida harmoniosa e saudável; também no âmbito político a disciplina pessoal desponta como um elemento essencial para que as práticas políticas de um líder possam se aproximar dos rígidos critérios que orientam a avaliação de seu desempenho. Apenas uma chefia capaz de cumprir este conjunto infindável de requisitos poderia ser um candidato potencial ao utópico papel de watalikana, um tipo de chefe cujas qualidades morais seriam tão elevadas que o colocariam acima de quaisquer contestações.

Todas essas características de comportamento e de personalidade definem critérios de seleção e/ou manutenção do apoio político a lideranças; elas não operam sozinhas, mas são parte de um conjunto de critérios mais amplos aos quais se somam a posição hierárquica clânica, a posição de 'irmão mais velho' e 'mais moço' e, nos dias de hoje, o domínio da língua portuguesa, falada e escrita.

Outro traço marcante da cultura e valores morais baniwa é a aversão que demonstram aos confrontos abertos e diretos entre as pessoas; esse tipo de incidente é pouco freqüente e, quando ocorre, suas conseqüências são imprevisíveis, interferindo pesadamente na continuidade da vida social. A violência irrefreada é um tema recorrente da mitologia baniwa; os tempos pré-humanos mostram uma variedade de situações em que o descontrole emocional gera conseqüências funestas que marcaram a vida humana para sempre. Nos relatos míticos, os principais descontroles a serem combatidos são a agressividade e a sexualidade transgressora; as doenças e infortúnios que hoje acometem o povo baniwa são fruto dessas transgressões e da perda do autocontrole pelos heróis ancestrais. ${ }^{45}$

A socialização dos novos membros do grupo enfatiza o exercício do autocontrole e boa parte das estratégias de prevenção de doença e rituais de cura se ordena através do desenvolvimento das disciplinas corporais e espirituais, do reforço ao ascetismo, do cultivo da sobriedade e da contenção dos impulsos pelos indivíduos. As relações cósmicas e sociais são concebidas como uma via de mão dupla, orientada pela noção de reciprocidade. Todos devem pautar suas ações pela idéia de que, se servir a alguém, futuramente será servido; se partilhar bens e favores, receberá em troca a mesma gentileza. Da mesma forma, quem enviar veneno, sopros ou outros malefícios quaisquer receberá de volta o mau conteúdo de suas ações. Nenhuma esfera da vida e do comportamento deixa de ser perpassada pela noção de reciprocidade, que coexiste com a tensão gerada pelo comportamento censurado, mas real, daqueles que tentam receber sem 
retribuir, instaurando as formas de reciprocidade negativa. Existe, portanto, uma partilha de responsabilidades entre indivíduo e sociedade na manutenção da ordem social.

A explosão da violência é um fantasma que ronda o cotidiano e ameaça romper a continuidade da vida social. Assim, uma das principais tarefas da chefia ${ }^{46}$ é a mediação dos conflitos diários para prevenir a irrupção da violência no grupo; quando ela ocorre, são poucos os mecanismos existentes para evitar que ela se alastre no corpo social. Um dos principais atributos do capitão é exercer os meios de dissuasão de tumultos, efetuando um monitoramento permanente sobre suas manifestações. Por razões como estas, a disciplina e o autocontrole são atributos extremamente valorizados no líder político, que deve se esforçar para não se envolver nas disputas e ciúmes que permeiam o corpo social.

Existe um último aspecto, mas nem por isso menos importante, da organização social baniwa que parece servir de contraponto às extremadas pressões exercidas sobre seus membros, para atender aos interesses comunais. Trata-se da valorização do esforço individual autônomo, da valorização obtida em virtude do próprio trabalho, da diligência e do mérito pessoal, elementos cuja relevância já foi assinalada em trabalho anterior de Wright (1992a). A busca da não-dependência do corpo social é um atributo que contrabalança a rígida hierarquia da sociedade e pode compensar, dentro de certos limites, uma desvantagem de nascimento. O lugar hierárquico de cada um na sociedade é herdado, mas isso representa somente uma pré-condição, uma potencialidade que pode se realizar ou não; a obtenção de reconhecimento social e de prestígio depende mais do esforço pessoal em confirmar a potencialidade outorgada por sua posição de nascimento, ou em negá-la, caso seja desfavorável. É inegável que a ocupação de uma boa posição hierárquica, de sib ou de geração, proporciona maiores oportunidades de acesso a certos nichos sociais - é mais fácil ser chefe sendo filho de chefe; estes também têm maior possibilidade de ocupar o cargo de agente de saúde -, mas isso não representa uma garantia automática de ocupação de tais lugares ou de um desempenho satisfatório. As regras de hierarquia têm um caráter mais orientador do que prescritivo.

O esforço individual também se expressa na relação ensino-aprendizado travada entre as gerações. Entre os Baniwa, a busca ativa de saberes é muito valorizada, não se vendo, como em outras sociedades, a insistência dos mais velhos em transmitir saberes que os mais jovens não mostrem interesse em aprender. Esta ética do esforço pessoal tem conseqüências importantes na apropriação desigual do acervo cultural disponível e vem contribuindo para uma interrupção na transmissão dos antigos saberes entre os membros das novas gerações. A motivação para dominar os processos simbólicos que garantem a reprodução do grupo, para aprender as técnicas que garantam a subsistência cotidiana e para chefiar parece se alimentar do desejo de prestígio que move os homens em busca de 
reconhecimento social e contém, em si mesma, os germes da diferenciação individual combatida pelos já demonstrados mecanismos de coerção social.

Mesmo a pessoa mais disciplinada, interessada, diligente e bem-sucedida na apropriação de bens simbólicos e materiais que façam dela uma liderança reconhecida e valorizada pode tropeçar, em algum momento de sua trajetória, no estopim disparador dos mecanismos da inveja, da difamação e do envenenamento, enfim, nos meios de controle da diferenciação. No mundo baniwa, o sucesso contém em si mesmo o germe de sua ruína. Indivíduo e sociedade são elementos constitutivos de um campo de tensão, no qual a energia do primeiro alimenta a existência do segundo, mas operando por meio de um balanço geral de forças que tendem a favorecer mais o grupo que a pessoa.

Notas

37 Overing (1983/1984) considera os grupos tribais ameríndios como sociedades que não praticam uma economia política, classicamente entendida como sistemas nos quais uma parte da sociedade teria o poder de controlar e usufruir os produtos do trabalho de outros. Ao contrário, o que se observa nos grupos étnicos sul-americanos é a existência de uma série de mecanismos sociais destinados a limitar ou mesmo impedir essa apropriação. Aqui, circulação dos bens e produtos do trabalho seria regulada pelos circuitos de troca - não mercantil - fundados na reciprocidade e nas obrigações de parentesco. É esse circuito de trocas ritualizadas que a autora denomina de "antropologia política dos bens".

38 Para Rivière (1984), o que caracteriza a economia política ameríndia não é a apropriação dos frutos da produção, e sim o controle dos membros da sociedade que são, entre outras coisas, produtores de bens. Dessa forma, as riquezas mais desejadas são os próprios membros da sociedade, bens escassos quando comparados ao grande número de inimigos perigosos e à riqueza de recursos ambientais disponíveis para o grupo. Em sociedades nas quais as pessoas constituem uma das principais fontes de poder e de prestígio, o que caracteriza a economia política são os meios de gerenciamento e de controle delas, e não dos bens produzidos com seu trabalho; na verdade, a maior parte destes grupos disporia de normas sociais que instituem a circulação obrigatória dos produtos do trabalho humano entre diversos níveis do corpo social. Dentre os casos estudados pelo autor, as estratégias que viabilizam esta "economia política das pessoas" passam pelo nível genealógico, com as gerações mais velhas exercendo o controle sobre os grupos mais jovens (reais ou classificatórios), e pelas diferenças de gênero, nas quais a mulher se situa como o pólo subordinado da relação. De modo semelhante, a proximidade/distância geopolítica entre o grupo local e seus aliados ou inimigos também faz parte dos meios de gerenciamento de pessoas, definindo possibilidades de aliança ou enfrentamento entre grupos.

O Baixo Içana congrega uma tal mistura de residentes, principalmente nas comunidades próximas à foz do rio, que se torna difícil a caracterização precisa do sib de influência em cada uma delas; entretanto, a predominância de chefias de aldeia Dzawenai permite caracterizá-lo como área de influência desta fratria. 
40 O termo Curipaco não se refere a uma fratria, e sim a uma variação dialetal. Entretanto, os sibs que exercem essa variedade de fala no Içana podem se comportar operativamente como uma fratria, tendo um território e uma unidade política bem caracterizados e estabelecendo relações de exogamia com as fratrias Hohodene e Walipere.

41 A composição das fratrias Hohodene e Dzawenai foi descrita por Wright (1981) e Hill (1984), respectivamente.

42 Nos relatos míticos as esposas de Nhiãpirikoli se sucedem, em geral advindas de grupos hostis com os quais ele está tentando estabelecer alianças e obter saberes; assim, ele toma esposas entre os peixes agressivos, entre os macacos Eenunai e outros seres não humanos, como o dono da noite. Também para os Baniwa de hoje, qualquer grupo não pertencente à sua fratria é um afim potencial. Na prática, pouco se observam casamentos com membros de grupos distantes ou hostis; em geral, os casamentos costumam seguir as regras de acordo e alianças entre as fratrias.

43 Sahlins (1983) chama atenção para o fato de que na nossa sociedade a categoria "não-parente" pode denotar interações positivas, geralmente pautadas na especialização profissional, como, por exemplo, relação médico-paciente, professor-aluno etc. Nas sociedades indígenas a relação entre não parentes costuma se apresentar como sinônimo de estranho e de inimigo.

44 A mudança de postura da Igreja Católica, que hoje se propõe a valorizar a cultura indígena e estimular a restauração de costumes abandonados, como as festas Pudali, é vista com desconfiança e descrença entre os capitães católicos. Em seu modo de pensar, as transformações no estilo de evangelização, longe de serem vistas como um fato positivo, são indicativas de pouca firmeza de posições dos padres atuais.

45 Lembrar que Kowai foi morto por ter perdido o autocontrole ante a desobediência dos jovens no primeiro ritual de passagem; os iniciandos, por sua vez, foram comidos por Kowaiapós quebrarem o jejum prescrito, devido à sua incapacidade de controlar a fome.

46 Não é apenas o chefe que intervém no controle da irrupção de conflitos na sociedade Baniwa. De modo geral os homens mais velhos e experientes também costumam ser acionados neste tipo de situação. O grau de intervenção varia em função da habilidade de cada um em lidar com o problema. A ênfase dada à figura do chefe decorre da preocupação que aqui temos de descrever suas atividades e habilidades; além disso, os chefes podem dispor de um maior background para a tarefa, já que costumam adicionar a posição de nascimento e o treino social a uma capacidade individual de mediar conflitos. 
Nos próximos capítulos nos preocuparemos em analisar as interações travadas pelas Organizações Indígenas de $\mathrm{Base}^{47}$ no âmbito das fratrias e sibs que formam sua base política, buscando entender como essas entidades não tradicionais se inserem na organização social baniwa e como essas condições contribuem para legitimar ou deslegitimar a atuação de seus líderes. Trata-se de buscar os mecanismos internos de expressão da autoridade política, analisando também os potenciais pontos de congruência e de conflito com os espaços institucionalizados - não indígenas - de exercício de poder.

Personagens habitualmente denominados 'tradicionais', como os xamãs, benzedores e chefias de aldeia, devem ser considerados como membros de um único campo cultural que também comporta os chamados 'agentes da modernização', isto é, agentes de saúde, professores e lideranças do movimento indígena. A dicotomia entre tradicional e moderno se rompe, à medida que cada um deles circula num espaço social multifacetado que produz posições sociais muito distintas entre si, variando ao sabor de circunstâncias que podem determinar, por exemplo, que uma jovem liderança indígena defenda a construção de malocas em aldeias e a retomada de rituais de iniciação hoje abandonados, ao mesmo tempo em que um xamã apóie a exploração garimpeira nas áreas indígenas. Nas condições atuais de vida dos Baniwa, as produções culturais do mundo não-indígena não são apenas exterioridades, muitos de seus elementos foram incorporados e circulam em diversos extratos sociais, inclusive naqueles que abrigam os detentores dos saberes mais centrais na cultura baniwa.

Às referências teóricas citadas no capítulo anterior, que também ordenaram a discussão dos dados aqui expressos, adicionamos as contribuições de Miguel Bartolomé (1995), que caracteriza os movimentos etnopolíticos como a busca do protagonismo político através da defesa dos interesses dos grupos indígenas, estruturadas em torno das manifestações da etnicidade, em geral reconstruída no próprio processo. As lutas étnicas podem ser consideradas espaços de disputa de relações simbólicas, através das quais se busca a conservação ou a transformação das correlações de força na sociedade e uma neutralização simbólica e material das 
desigualdades sociais, articulando a realidade política das aldeias com forças exteriores a elas, inaugurando formas de luta centradas no direito à diferença étnica e no acesso a bens e serviços oriundos da aplicação de políticas públicas.

Bartolomé (1995:365) também identifica como linhas fundamentais da prática política em sociedades indígenas "a normatividade do passado, a hierarquia e o consenso", fatores que permitem estabelecer conexões com a autoridade dos idosos, fundadas na hierarquia de gerações e nas relações de parentesco. Tais elementos são similares àqueles encontrados na sociedade baniwa, onde o poder político se apóia nos saberes simbólicos controlados pelos membros das gerações mais velhas que se atualizam e se redimensionam nas configurações assumidas pelo movimento indígena naquela área.

Um dos conceitos-chave no texto é o de poder político, que, para as finalidades analíticas deste capítulo, será articulado à idéia de 'poder social', caracterizado por Viveiros de Castro (1986:2) como "...aquele funcionamento normalizador e totalizador da sociedade sobre os indivíduos". Este conceito se aplica adequadamente à sociedade em estudo, na qual o poder político é exercido não em espaços centrais de autoridade coercitiva, e sim através de uma rede de interações sociais que incidem de forma pulverizada no cotidiano, exercendo uma forma difusa de coerção, que varia segundo os fatores conjunturais que modulam sua inflexão sobre os membros do grupo.

No entanto, os sujeitos dispõem da possibilidade de exercer o 'poder simbólico', caracterizado por Pierre Bourdieu (1989:19) como "...um poder de construção da realidade que tende a estabelecer uma ordem, um sentido imediato do mundo, em particular do mundo social".

$\mathrm{Na}$ interface entre estas duas formas de poder, conduziremos a análise dos modos de atuação das lideranças indígenas, aqui caracterizadas como núcleos discursivos que disputam com outros agentes políticos, intra e interétnicos, a legitimidade e a capacidade de produzir sentidos que possibilitem intervenção nos rumos da sociedade baniwa e nos espaços de negociação com instituições da sociedade nacional.

\section{Aviamento, o ontem e o hoje}

O aviamento na Amazônia já foi estudado por diversos autores, como Wagley (1977) e Santos (1980), mas análises como a de Aramburu (1994) mostram que o sistema permitiu ao produtor rural amazônico o acesso indireto ao sistema de crédito bancário, aos insumos agrícolas, à divisão internacional do trabalho e à economia de mercado, promovendo uma integração subalterna do produtor rural amazônico à sociedade regional, nacional e mundial. A obtenção de crédito 
diretamente dos estabelecimentos financeiros permitia a oferta, pelo aviador, de um financiamento indireto ao produtor rural, possibilitando-lhe o acesso imediato a mercadorias mediante a promessa de entrega futura de produtos extrativos.

O mesmo autor chama a atenção para o caráter paradoxal do aviamento que simultaneamente atrela o produtor à economia formal, mas se constitui também num obstáculo à difusão e aprofundamento das relações impessoais de mercado, na medida em que os vínculos estabelecidos entre o aviador e o aviado envolvem laços de compadrio e de fidelidade, pouco compatíveis com as formas de operar da economia moderna. $\mathrm{O}$ aviador também assume uma série de funções sociais de um Estado ausente; o produtor deposita sua confiança no patrão e nele busca apoio para a educação dos filhos e para o tratamento de familiares em caso de doença. Dessa forma, o aviamento monopoliza as relações do produtor com o mercado e com o Estado e se transforma numa barreira à modernização das relações sociais.

$\mathrm{Na}$ área baniwa, as interações travadas com o sistema de aviamento guardaram muitas dessas características, de tal maneira que, até a decadência final do extrativismo na década de 80 , os comerciantes aviadores, brasileiros e colombianos, se mantiveram como uma das principais vias de acesso às sociedades nacionais e às mercadorias industrializadas que se tornaram essenciais ao modo de vida indígena. A Igreja Católica, que se mostrava como uma alternativa, não era de fato diferente, já que movimentava um sistema de crédito similar ao do aviamento, feito através das chamadas cantinas, armazéns onde mercadorias obtidas por doação em outros locais eram adiantadas em troca de produtos extrativistas e artesanato, a serem pagos na estação seguinte; tratava-se de um verdadeiro sistema de financiamento a longo prazo, que a missão salesiana não conseguiu manter nos anos mais recentes.

No tempo de patrão, ele chegava e perguntava se tinha borracha, cipó, sorva ou chicle; aqui só tirava sorva, aí o patrão dizia: 'a sorva está dando um bom preço pra gente trabalhar; se tu tiver tantos quilos, sai assim tantos cruzeiros'; aí todo mundo escutava, ficavam escutando quanto era o valor do quilo; se estava como eles queriam, se eles ficavam de acordo, era só perguntar pro pessoal e, se eles queriam trabalhar, eles iam lá no patrão fiar, tirar crédito lá no porto. Quem queria, ia lá no porto e pegava um fiado... eles desciam no porto e tiravam o que precisavam; se queria espingarda, pegava espingarda, ou então roupa. Naquele tempo, ainda não tinha forno (para fazer farinha); o que tinha era terçado, machado, pólvora; a linha também não tinha nâo, só havia a linha americana, só; e anzol tinha; também dava pra tirar panela, prato, tabaco e cachaça. A pessoa tirava e depois juntava tudo, era um montão de mercadoria; depois disso ia trabalhar tirando sorva pra pagar; eles trabalhavam para os outros, né? Até que eles liquidavam a conta, mas logo depois faziam outra. (A .C., capitão curipaco) 
Com a falência do extrativismo, o acesso da população aldeada ao mercado se manteve através da venda de artesanato, mas o monopólio dos comerciantes que aviltavam o preço pago ao produtor, aliado ao elevado custo de produção decorrente do alto preço do transporte, grande distância do mercado e dos limites de uma produção centrada apenas na capacidade de trabalho de cada família nuclear munida de ferramentas rudimentares, mostrou-se incapaz de oferecer uma alternativa econômica adequada às necessidades da população.

No mundo baniwa, a subsistência está garantida; embora a pesca e a caça estejam progressivamente mais escassas, ainda não há necessidade de comprar comida para a alimentação diária; da mesma forma, é possível dispor dos materiais necessários para a moradia. Todos esses bens parecem estar escasseando e, pelo menos no entendimento dos indígenas, parece ser uma questão de tempo o seu completo desaparecimento, caso sua exploração mantenha os atuais padrões de baixa sustentabilidade.

Existe, porém, a necessidade de obtenção de diversos produtos industrializados que foram incorporados ao longo da história do contato e se tornaram imprescindíveis à reprodução material e simbólica da sociedade. Mercadorias como pilhas, anzóis, linhas e lanternas são hoje indispensáveis para a pesca cotidiana; o sal é necessário ao preparo do alimento; as casas exigem portas, pregos e dobradiças; a roupa tornou-se elemento essencial da identidade baniwa, sua manutenção exige produtos como sabão, linha e agulhas. Motor de popa e combustível são importantes para a manutenção da vida social, pontuada por festas, visitas, encontros religiosos e políticos, para as transações econômicas na cidade de São Gabriel e, sobretudo, para a remoção de doentes para o hospital na cidade. $O$ esforço pela obtenção dessas mercadorias, assim como dos serviços essenciais de atenção à saúde e à educação, constitui-se hoje uma poderosa via de mobilização das pessoas nas aldeias.

Quando deixaram de percorrer os rios, os comerciantes criaram uma lacuna que ainda não foi preenchida por outro ator econômico e as comunidades se mantêm na busca de outros agentes de mercado que possam suprir tal papel. É a partir dessa ótica que se pode entender a aceitação da Goldamazon, uma mineradora que atuou no Alto Rio Negro na década de 80 . Segundo alguns informantes, os Baniwa estavam atrás de um 'patrão' a quem pudessem vender seus produtos e oferecer sua mão-de-obra, reinserindo-se assim na economia de mercado. Rechaçados pela mineradora, desinteressada do que lhe era oferecido, continuaram sua busca através de alternativas como o populismo eleitoreiro e atualmente do trabalho da Organização de Base. Voluntariamente ou não, os dirigentes das Organizações Indígenas são pressionados a exercer o papel do aviador; essa expectativa se perpetua em torno deles, apesar da superação histórica do modelo extrativista que impossibilita a manutenção do sistema de aviamento. 


\section{Poder político e organização social baniwa}

O trabalho político hoje desenvolvido pelas Organizações de Base reflete, em grande parte, as tensões do parentesco expressas na distribuição geográfica e nas fissões periódicas das aldeias que lhes proporcionam base de apoio. Estas tensões costumam redundar no incremento ou retirada do apoio político à entidade e são acompanhadas com atenção por seus dirigentes, que têm clara noção de suas repercussões sobre seus mandatos. Os princípios que orientam os critérios de exercício de poder, legitimidade e desempenho das chefias de aldeia trabalhados no capítulo anterior, são aplicados também ao trabalho das lideranças de Organização Indígena, não havendo, neste sentido, uma descontinuidade significativa entre as duas formas de exercício de vida política.

Entretanto, as formas de atuação das Organizações não deixam de representar novas estratégias de intervenção social, pois sua busca por uma posição menos assimétrica nas relações interétnicas as leva a negociar com instituições não inscritas na sua tradição. Em razão disso, os líderes das associações têm uma parcela de sua legitimidade garantida pela escolaridade e domínio de saberes do mundo do branco, sendo a outra fundada nas relações de parentesco que determinam o status que a sociedade lhes atribui por nascimento e que pode operar como sistema de partida, por sobre o qual a liderança constrói sua carreira política.

Para iniciar a discussão sobre a atuação das Organizações de base da área baniwa, procederemos a uma descrição sumária dos padrões atuais de assentamento e distribuição de sibs e fratrias no território baniwa, pois tais elementos se mostram essenciais para o entendimento de suas estratégias de atuação. No Brasil o povo baniwa conta com uma população aproximada de 4.840 indivíduos, hoje distribuída em 94 assentamentos (ISA/Foirn, 1997) nos Rios Içana, Aiari, Cuiari, Quiari e afluentes, ${ }^{48}$ que comportam a divisão expressa no Mapa 3 (vide Anexo).

Como se pode observar, cada Organização Indígena atua sobre determinada parcela de território frátrico que equivale à sua base política e em cujos sibs busca legitimar-se. Além das questões relativas ao parentesco, essas regiões têm características geográficas e ambientais diversas e diferentes histórias de contato, expressando-se como um mosaico de múltiplas influências que determinarão os resultados obtidos no trabalho político das entidades. Em termos geopolíticos, a área baniwa está assim configurada:

O Baixo Içana, compreendido entre a foz do rio e a aldeia de Tunuí, é uma região de maior proximidade com a área urbana e de mais fácil acesso pela via fluvial; ao longo da história do contato sofreu mais influência do processo colonizatório. A população desta subárea tem maior contato com as agências da sociedade nacional, acesso mais fácil à assistência à saúde, escolas municipais, 
aparelhos de TV e antenas parabólicas instalados em boa parte das comunidades. A missão salesiana sediada em Assunção, bem no centro desta área, exerce considerável influência sobre as localidades católicas.

A intervenção das empresas mineradoras na década de 80 gerou grande impacto nesta sub-região, particularmente porque as aldeias evangélicas apoiavam sua presença e enfrentaram a oposição das comunidades católicas. O conflito, deliberadamente incentivado pelos funcionários da empresa, deixou marcas profundas cujos efeitos ainda hoje repercutem e vêm dificultando a organização etnopolítica dos grupos ali assentados.

As lideranças de aldeia do Baixo Içana mantêm alianças permanentes com a política partidária de São Gabriel da Cachoeira, emprestando apoio a prefeitos e vereadores em troca de bens de consumo, como roupas, ferramentas e insumos agrícolas em geral. Tal influência se espraia ao longo de todo o Içana e afluentes, mas se torna mais diluída à medida que se sobe o rio; as dificuldades de navegação e a rarefação demográfica das comunidades tornam pouco atrativo o investimento em práticas populistas nas regiões mais distantes, de acesso difícil e poucos eleitores. O rendimento eleitoral se mostra mais proveitoso nesta subárea populosa do território baniwa, já que a mesma congrega uma população estimada de 2.251 pessoas, pouco menos da metade da população baniwa aldeada (ISA/Foirn, 1997).

A fratria de maior influência política nessa região é a Dzawenai, mas a recolonização forçada das décadas anteriores gerou a mistura, atualmente encontrada, de sibs e fratrias nas aldeias. Os padrões de assentamento populacional no Baixo Içana são distintos daqueles tradicionalmente encontrados em outros espaços da terra baniwa, nos quais existe uma definição bem marcada na ocupação do território por cada fratria.

Em termos geopolíticos, pode-se dizer que Tunuí, uma grande cachoeira que representa uma importante barreira física à entrada de agentes de colonização oriundos do lado brasileiro, demarca a fronteira com a sub-região localmente denominada de Médio Içana, que é a área de principal influência da fratria Walipere e da Organização Indígena da Bacia do Içana (Oibi), comportando 16 localidades falantes de Baniwa. Dessas, 13 são dos sibs Walipere, duas são controladas por sibs da fratria Dzawenai e uma outra é cindida ao meio, enfrentando fortes conflitos políticos entre membros de sibs Hohodene (católicos) e Walipere (evangélicos) que residem no mesmo local. No Médio Içana, onde se situa hoje o pólo mais dinâmico do movimento indígena na região, há uma predominância de aldeias evangélicas; do total de 16 aldeias que formam a base política da Oibi, seis praticam a religião católica.

As aldeias são pequenas, com população variando de 13 a 85 pessoas por comunidade, mas o hábito de realizar Conferências evangélicas ${ }^{49}$ facilita a 
organização política e a capacidade de mobilizar rapidamente um grande número de pessoas para outras finalidades; tais condições favorecem uma interação entre as aldeias e a disseminação de propostas e atividades do movimento indígena.

A sub-região já contou com a presença da missão Novas Tribos, que hoje detém apenas uma base fixa nesse rio. A escassez atual de missionários não-índios não parece afetar a prática do evangelismo nas aldeias, cada uma das quais conta com um 'ancião', ou seja, um membro indígena, considerado como pessoa versada na Bíblia, que assume o papel de coordenador local das práticas religiosas e exerce influência política no cotidiano da aldeia (Journet, 1995). O trabalho do ancião representa uma forma de autonomia religiosa, pois, diferente da Igreja Católica, que exerce o monopólio das prédicas religiosas, o evangelismo indígena é desenvolvido de modo independente das igrejas dos brancos.

O território curipaco, na área conhecida no Brasil como Alto Içana, conta com 16 aldeias, todas evangélicas. Essa região sofreu, ao longo das últimas décadas, forte influência do pelotão do Exército brasileiro estabelecido bem no centro da área. Dada a completa ausência de outros órgãos de governo, o pelotão tem suprido algumas funções de assistência à saúde e educação e formação de vínculos com a sociedade nacional brasileira, apesar da inadequação de suas ações às necessidades da população. Igualmente, a presença do grupo missionário Novas Tribos se manteve relativamente constante, contando com um missionário residente na aldeia de Jerusalém. A permanência dessas instituições tem exercido uma influência contrária à constituição do movimento indígena no local; a área curipaco tem mostrado, ao longo dos últimos anos, um conservadorismo político e uma certa oposição às propostas ambientalistas e de revitalização da etnicidade que emanam do movimento indígena; seus chefes de aldeia têm apoiado propostas desenvolvimentistas como as do projeto Calha Norte, a presença de mineradoras e outros agentes de colonização.

O Aiari, com 22 aldeias, tem sua população dividida entre católicos e protestantes, sendo os primeiros majoritariamente membros dos sibs da fratria Hohodene o últimos representados por sibs da fratria Walipere, ali residentes. A influência da missão salesiana foi grande neste rio, enfrentando acentuada decadência nos últimos anos. As observações atuais dão conta de uma incapacidade institucional católica em manter a intensa ação de décadas anteriores. Atualmente, as atividades missionárias se reduzem a viagens periódicas de religiosos pouco entusiasmados, levando os sacramentos e um simulacro de assistência médica, cuja má qualidade tornou-se cada vez mais evidente com a oferta de serviços de saúde pelo recém-implantado Distrito Sanitário Especial Indígena. A decadência da missão, que intervinha incisivamente na vida cotidiana das pessoas, desestimulando as iniciativas autogestionárias, deixou um vazio que ainda não foi preenchido por atores políticos indígenas que possam emergir do processo. 
Os grupos do Aiari contam com outra presença muito importante, os xamãs, os últimos em atividade em todo o Alto Rio Negro, que exercem uma influência direta sobre as comunidades católicas, e indireta, mas nem por isso menos efetiva, sobre aquelas que são evangélicas. As aldeias de origem dos principais xamãs vêm direcionando suas alianças políticas no mundo dos brancos para a Prefeitura de São Gabriel, o que tem repercussões sobre o alcance do movimento indígena local, representado pela Acira.

As características da organização social baniwa exercem influência sobre os modos de funcionamento das Organizações de Base que congregam grupos de parentes (e, às vezes, também seus afins) através de obrigações sociais recíprocas estabelecidas desde épocas anteriores ao contato, constituindo-se como mais um (dentre outros) meio de demarcação de uma identidade de uso local, no cadinho pluriétnico do Alto Rio Negro.

As obrigações de reciprocidade equilibrada que regem as relações entre sibs e fratrias atinge não apenas a convivência cotidiana, mas também se estende à redistribuição dos bens obtidos pelas Organizações nas instituições nãoindígenas. Dessa forma, a escolha de agentes de saúde, a distribuição das radiofonias, motores de popa, outros bens de consumo obtidos com a Foirn, e o subsistema de saúde indígena é menos orientada pela racionalidade técnica e mais pelas linhas de poder que demarcam as interações dos grupos de parentesco (Garnelo, 2001). Por outro lado, como estes agentes da modernização tampouco dispõem de poder de mando, podem utilizar o prestígio conferido por tais bens e serviços para ampliar seu espaço de negociação e convencimento das chefias mais velhas, junto a quem buscam legitimar-se.

Retomando a base geográfico-cultural - mostrada anteriormente, no Mapa 3 - a partir da qual as associações baniwa se organizam, vemos que elas praticamente coincidem com as áreas de distribuição territorial das respectivas fratrias; assim, verificamos que a Acira é uma entidade que representa majoritariamente os Hohodene; a Oibi congrega principalmente a fratria Walipere; a Oicai representa sibs de falar curipaco; a Unibi e a Aibri dividem entre si o território controlado pela fratria Dzawenai do Baixo Içana, havendo uma divisão bém evidente entre ambas: a área da Unibi cobre os falantes de Baniwa do Baixo Içana, e a Aibri, os falantes de Nheengatu; dentro da área de abrangência da Oibi e da Acira estão encravados alguns assentamentos de outras fratrias, que assumem o papel de minorias políticas na subárea.

Sob o rótulo de diferenciação geográfica encontramos diferenciações de fratrias, que expressam as configurações assumidas pelo poder local. 
No mundo baniwa, a vida cotidiana está impregnada da religiosidade que perpassa todos os elementos constitutivos da sociedade e do cosmos, não sendo possível (nem desejável) separar ação política da religiosidade, o que confere à primeira uma singularidade de atuação e contribui para definição de um estilo de ação característico das lideranças do movimento indígena.

Wright (1994) utiliza o conceito de mitopráxis, para problematizar os movimentos sociorreligiosos em grupos indígenas do Brasil, demonstrando que várias dessas manifestações são atualizações rituais de produções míticas preexistentes, numa busca de transformação simbólica (e, às vezes, material) da realidade encontrada num momento histórico determinado. A apropriação e ressignificação de um produto da alteridade como a doutrina cristã se fez em consonância com a estrutura simbólica do pensamento nativo (Barabas, 1989), (Wright, 1981, 1994).

Os conflitos entre evangélicos e católicos são temas recorrentes em qualquer conversa nas aldeias. As posições intermediárias são indesejáveis e todos têm de definir seu lugar; tais opções permitem uma caracterização do interlocutor como aliado ou adversário potencial. Esta polarização é congruente com as produções culturais baniwa, cujos mitos evidenciam que uma das principais fontes de tensão nessa sociedade são as relações de afinidade, boa parte das quais se expressa hoje nos conflitos estabelecidos entre cunhados de sibs evangélicos e católicos.

A religião professada pela liderança de Organização Indígena também influi na concessão ou retirada de apoio à sua atuação; entidades como a Acira e a Oibi que têm crentes e católicos entre suas bases, têm de lidar com a desaprovação a priori dos capitães de religiões contrárias; isso gera a necessidade de manter contatos mais freqüentes e intensos com seus oponentes religiosos, na tentativa de evitar a perda de legitimidade e credibilidade potencializada pelos boatos e desconfiança mútua.

É possível verificar no território baniwa diferenças fundamentais nas relações políticas travadas entre líderes de aldeias católicas e evangélicas; os primeiros têm níveis mais rarefeitos de interações entre si, parecendo mais voltados para as disputas do mundo intracomunal, gozando de poucas oportunidades de reunir diversas aldeias, como ocorria outrora nos rituais pudali. Entre os evangélicos, as Conferências contribuem para o incremento da organização política das aldeias, pois elas propiciam reuniões trimestrais ou quadrimestrais de um grande número de pessoas, facilitando a troca de opiniões, a circulação de informações e versões explicativas de fatos políticos, e favorece, além disso, a tomada coletiva de decisões.

Estes eventos já eram, antes da formação das Organizações Indígenas, um meio de avaliação do desempenho dos líderes políticos e religiosos e passaram 
a absorver também a função de controlar a atuação dos jovens que atuam nas fronteiras das relações interétnicas. Não por acaso, as mudanças de diretoria de entidade nas áreas evangélicas ocorrem com maior freqüência quando há descontentamento dos capitães com sua atuação.

As tensões entre católicos e evangélicos podem ser consideradas como uma dentre as diversas estratégias de demarcação nas relações identidade/ alteridade; as diferentes formas de conversão operam como delimitadores das diferenças polarizadas entre consangüíneos e afins. As disputas religiosas são formas de expressão de relações de força, de afirmação de alteridades em luta, que tentam exercer um poder simbólico capaz de impor sua própria visão de mundo, concebida como única e legítima forma de organização da sociedade (Bourdieu, 1989). As lideranças de Organização de base atuam num cenário onde, apesar de sua condição de 'especialistas políticos', não gozam de uma credibilidade imediata; ao contrário, têm de trabalhar arduamente para fazer valer seus pontos de vista e se equilibrar numa instável condição de mediadores que buscam obter consensos a partir de pares de oposições onde se conflagram afins e consangüíneos, evangélicos e católicos, moradores do Içana e do Aiari.

Para Faulhaber (1994:97), o movimento reivindicatório indígena, mesmo se situando no plano político-secular, é nutrido por conteúdos utópicos oriundos de campos políticos e religiosos e produz inferências sobre as condições sociais que instituem as identidades étnicas, implicando uma aspiração de concretização de utopias que sustentam o imaginário mítico nativo. Para a autora, os movimentos étnicos geram eficácia mobilizadora da sociedade ao se apropriarem, simultaneamente, de aspectos do imaginário da cultura ocidental, ao incorporar símbolos do cristianismo e ao reinterpretar a identidade mítico-étnica de acordo com os novos parâmetros apreendidos no contato interétnico.

No mundo baniwa as lideranças também podem ser vistas como instrumentos do sagrado, responsáveis pelo resgate físico e metafísico de seus liderados, percorrendo uma trajetória que deve se harmonizar com a dos líderes messiânicos, bem conhecidos nesta cultura. Sob um desempenho aparentemente laico, esconde-se um componente profundamente religioso que orienta as expectativas socialmente produzidas em torno do trabalho político.

A interação das lideranças evangélicas com as concepções mítico-religiosas da cultura baniwa se expressa ainda na forma rigidamente disciplinada de sua atuação. Delas é cobrado o seguimento rigoroso das regras alimentares e de higiene e a participação regular nos cultos e Conferências evangélicas. Tal religiosidade auxilia na organização cotidiana de suas vidas, disciplina seus esforços e impulsiona seu trabalho político e conquistas econômicas, representando um encontro entre antigos padrões de comportamento e formas atuais de sociabilidade (Journet, 1995). O fervor religioso, a prestação de serviços e atendimento a demandas consideradas 
relevantes pelo grupo são também fontes de legitimação e de acumulação de poder simbólico usado na busca de consensos e de equilíbrio nas relações entre os sibs que formam sua base política. O que os capitães exigem das Organizações e os líderes exigem de si mesmos é a concretização, em seu trabalho e vida, dos padrões morais ideais da cultura baniwa. A ação política baniwa pode ser concebida, então, como uma incorporação ressignificada de elementos do mundo não-indígena, desde que estes guardem congruência com a cosmologia preexistente (Wright, Pablo, 1994).

Embora as lideranças percebam os limites do pensamento mítico em propiciar uma adequada sustentação para suas atividades atuais e compreendam que o espaço/tempo cíclico da cultura indígena não consegue lidar com as mudanças, cada vez mais aceleradas, da sociedade mundial, com as quais o movimento indígena deve interagir, elas não podem e nem desejam romper com os antigos saberes, pois conhecem os prejuízos que tal ruptura acarretaria para a legitimidade de sua atuação política. Isso as leva a um exercício de apropriação crítica dos elementos de sua cultura, trazendo a ordem político-econômica não-indígena para o campo étnico, gerando uma ampliação do próprio conceito de identidade étnico-cultural e da idéia de poder, habitualmente permeada em todo o corpo social e que passa a ser associada também aos aparelhos de Estado. Configura-se, aqui, um processo que Sahlins (1988) denomina de "desenvolvimento neotradicional", no qual a mediação feita pelos agentes políticos locais gera formas diferenciadas de apropriação das forças econômicas e políticas mais globais, que podem representar inclusive um enriquecimento do sistema local e não apenas uma troca baseada na desigualdade e na transferência lucrativa dos bens locais para a metrópole (Sahlins, 1988:54-55).

47 Organizações de Base devem ser aqui entendidas como entidades etnopolíticas que atuam no plano local, efetuando simultaneamente uma intermediação com o cenário do movimento indígena no Alto Rio Negro, formado por outros grupos étnicos e com agentes/instituições da sociedade nacional globalizada. Elas se caracterizam como mediadoras entre vida personalizada das solidariedades clânicas e o mundo público, impessoal e burocratizado das instituições do mundo não-indígena.

48 Os dados aqui citados se referem exclusivamente à população baniwa residente na área rural de São Gabriel da Cachoeira. Estão excluídas destas informações as populações residentes em áreas urbanas e em outros municípios.

49 Conferências são grandes reuniões de finalidade religiosa, nas quais a população de diversas aldeias geograficamente próximas se reúne periodicamente para a celebração de cultos evangélicos, o que confere um alto grau de interação e articulação política entre as chefias; no intervalo das Conferências são realizadas as Santas Ceias, eventos que reúnem um número menor de participantes, mas com finalidades semelhantes. 



\section{Organizações de Base do Içana e Aiari}

Usando como eixo de análise a atuação da Oibi e da Acira e tendo como contraponto as recém-criadas Onere, Aibri (Associação Indígena do Baixo Rio Içana) e Oicai, estabeleceremos uma correlação entre os dados até aqui descritos e a ação política delas também na realidade mais ampla do Alto Rio Negro. A análise será perpassada pela clivagem entre católicos e evangélicos, porque é impossível falar das relações intercomunais nessa região sem se referir às tensões entre esses dois tipos de práticas religiosas, que ordenam e dividem o mundo dos informantes e que seguem os trilhos a partir dos quais se pensam as relações de afinidade e alteridade.

Pode-se dizer que existe ação política quando identificamos a movimentação de atores e instituições em busca de construir objetivos comuns (Kushinir \& Carneiro, 1999). Neste sentido, as Organizações Indígenas se aglutinam em torno de dois tipos de objetivos comuns: um voltado para a intervenção no mundo não-indígena, ou seja, nas instituições de saúde, de educação, de desenvolvimento agrícola, de política partidária, na Funai e mesmo na Foirn. ${ }^{50} \mathrm{O}$ segundo tipo de objetivo é voltado para as aldeias, espaços em que os líderes de organizações indígenas de base constroem alianças com os chefes locais e buscam ampliar sua legitimidade para a consecução dos projetos partilhados, em parte selecionados pela diretoria da entidade e em parte definidos a partir de pressões e demandas dos capitães e seus liderados.

Tal situação pode ser exemplificada com a fundação da principal Organização de Base da área baniwa, a Oibi. Antes dela os capitães fizeram, no final da déćada de 80 , várias tentativas de negociação com a empresa mineradora que invadira seu território. Os fracassos evidenciaram a fragilidade de suas estratégias para lidar com os complexos interesses de mineração, redundando em acirramento de conflitos internos e na formalização de acordos lesivos aos interesses indígenas. O problema evoluiu para um conflito armado, no qual os índios danificaram equipamentos e expulsaram os empregados da mineradora de seu território; em represália, diversos deles foram presos. $\mathrm{O}$ episódio tornou clara a necessidade de criação de entidades especializadas em entabular negociações com 
as instituições e grupos econômicos não-indígenas, propiciando, na década de 90 , a proliferação das Organizações de Base que hoje atuam na região.

As lembranças de informantes mais velhos que participaram da assembléia de fundação da Oibi em 1992 mostram um processo consciente e deliberado de construção de alianças políticas dos sibs em torno da nova entidade; a ela foi outorgada a missão de costurar uma aliança sólida entre sibs católicos e evangélicos, congregando as facções políticas mais importantes, aglutinando-as em torno de um projeto político comum, fundado nas propostas do movimento indígena, mas atendendo às peculiaridades da organização política local.

Da primeira diretoria ficaram de fora as comunidades que apoiavam o garimpo e que se posicionavam contra a fundação da entidade, feita sob os auspícios de capitães contrários à presença garimpeira. Em termos frátricos a eleição encobria um confronto político entre Hohodene e Walipere, vencido pelos últimos, que obtiveram - e mantêm até hoje - o controle da entidade. A influência dos capitães da fratria Walipere, que tinham participado da movimentação recente contra o garimpo foi decisiva para o resultado final do processo político em curso.

A composição da primeira diretoria girou num limitado universo de escolha, o das pessoas com uma adequada posição na hierarquia dos sibs e a escolaridade necessária para dirigir uma entidade que operava nos moldes das instituições de branco. As opções eram ainda mais restritas entre os evangélicos, cuja recusa em enviar os filhos para as missões católicas limitava muito o número de jovens que tivessem cursado além da $4^{\text {a }}$ série do ensino fundamental, o limite do ensino regular ministrado nas escolas disponíveis nas comunidades.

Retomando a idéia de Rivière (1984) de "economia política das pessoas", pode-se dizer que indivíduos qualificados para exercer funções modernizantes são até hoje bens escassos e valorizados na sociedade baniwa. A disputa dos capitães pelo controle desses personagens mostra que os mesmos buscam, por essa via, garantir interveniência sobre a vida política comunal.

\section{Legitimidade}

Smith (1987a), estudando Organizações Indígenas no Peru, estabeleceu uma série de parâmetros ligados à legitimidade, autonomia e identidade de entidades indígenas que atuam naquele país. $\mathrm{O}$ autor questiona quem escolhe $\mathrm{e}$ como são escolhidas as lideranças indígenas e se sua legitimidade é fundada nas relações tradicionais de poder ou por critérios oriundos da situação colonial.

A investigação no Içana demonstra que, na escolha de agentes indígenas de saúde e de lideranças de Organização, os critérios oriundos das relações de contato interétnico são importantes, mas não conferem à liderança uma completa 
autonomia e independência das chefias de aldeia; ela recebe uma delegação instável e provisória, cuja legitimidade pode ser rapidamente contestada. O que se observa aqui é a construção de um tipo de identidade política, que, não sendo centrada exclusivamente na tradição, promove uma manipulação no capital simbólico ${ }^{51}$ detido por alguns membros do grupo e permite um reencontro e um reforço da 'comunidade étnica' que busca se apropriar e utilizar, para seus próprios fins, dos saberes ligados à dinâmica do contato.

$\mathrm{Na}$ área baniwa, a base de legitimidade que garante a sustentação política dos mediadores do contato interétnico deve ser buscada a partir da interseção entre o domínio dos saberes do mundo do branco e os atributos adequados ao exercício das funções da chefia de aldeia. A educação formal é um requisito básico ao trabalho da liderança, mas não é condição suficiente para legitimá-la. Critérios como posição hierárquica do sib de origem, respeito às regras de boa convivência social, habilidade de falar em público, capacidade de convencimento e/ou de prender a atenção de uma platéia, esforço pessoal, autodisciplina e o respeito aos valores morais enfatizado na cultura baniwa são tão ou mais importantes que a escolaridade na aceitação de uma liderança, o que confere um caráter endo-referido à sua legitimação.

O modelo de Organização Indígena foi construído historicamente a partir da apropriação de formas institucionais não-indígenas, cujas características foram sendo ressignificadas por seus praticantes ao longo do processo de incorporação. Porém, as relações políticas estabelecidas por elas obedecem também a um padrão típico de sociedades sem um poder central de Estado, nas quais a chave da organização política tem que ser buscada no parentesco; neste, o princípio de segmentação permanente gera tensões e disputas internas, por meio das quais os diferentes grupos que formam a sociedade buscam o equilíbrio.

Segundo Wright (1981), as fratrias são elementos de grande importância na organização do mundo baniwa, pois através delas se regulamenta o direito de exploração das riquezas naturais do território, as regras de exogamia e os saberes rituais que garantem a reprodução das relações sociais. Em função das interações dinâmicas entre seus elementos constitutivos, a sociedade oscila entre a 'hierarquia', cujo campo principal de expressão é a interação intra e inter sibs, e 'igualitarismo', que se expressa na relação entre as fratrias, campo onde se evidenciam mais abertamente as disputas e a competitividade. As interações políticas entre sibs e fratrias são cruciais para a compreensão da legitimidade e representatividade das associações indígenas.

O trabalho dessas agremiações recobre a distribuição territorial frátrica, podendo receber apoio e/ou oposição dos sibs que compõem sua base. No Alto Rio Negro, as relações consideradas como mais legítimas e estáveis são aquelas travadas entre consangüíneos; tal como na guerra, a aliança entre Organizações que representam grupos frátricos diferentes tende a ocorrer apenas quando há 
necessidade de enfrentamento de inimigos externos, como os brancos ou entidades representativas de outros povos indígenas.

A educação formal ${ }^{52}$ auxilia no aprendizado das atividades políticas advindas do contato e é sem dúvida o mais importante dentre os critérios legitimadores não-oriundos do mundo baniwa, conforme se pode observar no depoimento a seguir:

Quando a gente fazia a assembléia, não tinha também uma pessoa inteligente, de estudo mais ou menos. Aqui no Rio Içana tem pouca pessoa que tenha estudo de $1^{\circ}$ grau e de $2^{\circ}$ grau, só tem de $4^{a}$ ou $5^{a}$ série malmente. Então, nesse ponto aí não dava pra gente eleger um da gente lá porque lá, na Federação, precisa de uma pessoa que entende pouco as coisas, que entende palavra, português mais ou menos, que entende ouvir as palavras dos brancos, que sabe escrever melhor um pouquinho... mas já passou esse tempo, apareceu esse já novato, o moço daqui do Rio Içana, que teve já a $8^{a}$ série, então já dava pra gente eleger um da gente; foi aí que nós encaminhamos, podemos dizer, empurramos ele pra frente...antes não dava porque a maioria da gente não tinha estudo ... (R. P., vice-capitão Dzawenai)

Se por um lado os capitães reconhecem a necessidade de eleger representantes com escolaridade suficiente para aprender a lidar com os complexos problemas da política indígena e indigenista, por outro, não estão dispostos a abrir mão de sua autoridade em favor de jovens, capacitados ou não, para lidar com os saberes dos brancos. Ao contrário, o que se observa é que as habilitações obtidas pelos jovens, seja no campo da saúde, da educação ou da política indígena, têm sido utilizadas como instrumento de reforço ao poderio dos capitães, para reafirmar sua própria importância não apenas entre os co-residentes, ou entre os afins nos rios vizinhos, mas também entre os outros grupos étnicos do Uaupés, Tiquié e Rio Negro.

Se tomarmos o agente de saúde como um exemplo desta situação, podese ver que este personagem é hoje, no Içana, um dos elos de uma corrente de relações familiares, em cujo núcleo central está o capitão. Este, por sua vez, articula uma rede de alianças entre parentes e opera como uma 'máquina' de captação de recursos de subsistência e sobretudo bens industrializados; sua maior ou menor capacidade de obtê-los se reflete no poder que pode exercer no seu grupo de influência. Quando tem vários filhos, procura distribuí-los em diversos papéis que possam reforçar seu prestígio e importância. Assim, encontramos capitães com filhos soldados, agente de saúde, professor etc.; em geral, as duas últimas profissões são desempenhadas pelos mais novos, que puderam estudar um pouco mais, através do esforço conjugado do pai e irmãos mais velhos, para custear os estudos fora da aldeia. Nesse contexto, o trabalho do agente é concebido por ele mesmo, e pelo próprio capitão, como um meio de sustentação do poder político do pai, tio ou avô. 
Ao contrário do que parece à primeira vista, o exercício destas funções 'modernas' não significa trilhar um caminho rumo à individualização, mas tende a reforçar as relações aldeãs de poder; dispor de um agente de saúde na comunidade é sem dúvida um privilégio, e os capitães o guardam ciosamente.

No requisito da hierarquia dos sibs contam, simultaneamente, a posição hierárquica do sib de origem da liderança e a posição de senioridade de seus ascendentes. As relações de senioridade não ocorrem apenas entre os sibs, mas também se expressam dentro deles, atingindo famílias e indivíduos, sendo herdadas a partir da ordem cronológica de nascimento de seus ascendentes diretos (pai e avô) em relação a outros homens de suas gerações e atualizada na geração de ego, a partir da ordem cronológica de nascimento de ego e de seus irmãos, no interior de sua família nuclear. Tomando como exemplo as famílias da aldeia Tucumã Rupita, no Içana, é possível observar que nela existem cinco famílias classificadas entre si em uma ordem hierárquica, tradicionalmente estabelecida.

Segundo os relatos coletados, o chefe da família considerada 'mais velha' tem a prioridade na ocupação dos postos disponíveis na comunidade; na ausência de membros da primeira família na hierarquia, a prioridade na ocupação de cargos passa para a família seguinte, e assim por diante. A pesquisa de campo demonstrou que o papel de capitão e o cargo de agente de saúde estavam sendo ocupados por membros da família mais prestigiada residente na aldeia, mas a direção da Organização de Base (Oibi) era controlada por membros da penúltima família na hierarquia da aldeia.

As razões para essa aparente disparidade podem ser buscadas na singularidade do momento político. Na época da fundação da Oibi, as famílias mais prestigiadas de Tucumã não dispunham de representantes qualificados para dirigir a entidade, já que nenhum de seus membros detinha a escolaridade necessária para a tarefa. O primeiro presidente eleito ocupava um lugar de 'mais novo' quando comparado a outras famílias de Tucumã; esse fato, porém, tinha mais importância no plano interno da aldeia, pois no âmbito interlocal a filiação a um sib prestigiado adquire maior relevância e o presidente eleito pertencia a um sib considerado adequado para o desempenho de funções políticas na sociedade baniwa. Após a primeira eleição, o status adquirido com o bom desempenho à frente da entidade relativizou mais ainda as influências decorrentes de sua posição na hierarquia social.

Em resumo, a posição ocupada por nascimento na hierarquia do parentesco é importante, mas também não é o único fator de peso na definição de quem ocupa cargos, e em que seqüência, no mundo baniwa. A norma social orienta e regula as posições na hierarquia social, mas não obriga a uma obediência inflexível; não sendo prescritiva, a regra deve se curvar às conjunturas e às exigências da realidade (Sahlins, 1988). 
Apesar disso, é perceptível o esforço das lideranças indígenas para obter um equilíbrio na distribuição de cargos entre as famílias, de acordo com sua posição na hierarquia da sociedade. Habitualmente a distribuição de cargos procura contemplar, de forma relativamente equânime, os membros do sexo masculino de todas as famílias, evitando (ou limitando) as disputas e conflitos daí decorrentes.

A observação participante de assembléias também pode ilustrar a concepção hierárquica subjacente às atividades do movimento indígena. No início do evento, o ritual de apresentação dos participantes é feito segundo a ordem de senioridade dos presentes: primeiro se apresentam os capitães que formam a base política da entidade; um deles, com freqüência um dos mais idosos e prestigiados, fala em nome do grupo, e seu discurso já expressa algo dos pontos mais importantes que devem ser discutidos na assembléia; não são incomuns os entendimentos antecipados entre a diretoria da entidade e os líderes idosos de sua confiança, costurando um acordo prévio, capaz de viabilizar as propostas encaminhadas pela direção da Organização.

A ordem de fala durante o evento pode variar segundo a dinâmica do evento, mas a forma de enunciação do discurso segue a mesma lógica dos falares dos capitães; quem fala em nome do grupo costuma ser um membro de sib prestigiado, preferencialmente de maior idade cronológica. Num espaço social minuciosamente esquadrinhado, nenhum dos presentes deixa de ser apresentado, identificado e classificado na hierarquia dos papéis desempenhados na assembléia; os pronunciamentos feitos ao longo dela obedecem à ordem de precedência da senioridade. Em geral, os mais jovens e/ou menos prestigiados esperam o que os discursos dos velhos se esgotem para se pronunciar.

As oportunidades e as seqüências de fala são ritualizadas, de modo que existem falas enunciadas pelos velhos para os seus iguais, outras produzidas por eles, mas dirigidas aos jovens, às autoridades presentes ou à direção da Organização Indígena. Os tempos e formas de fala são demarcados para enfatizar cada papel social que está sendo desempenhado e explicitado pela enunciação do discurso. As falas dos jovens, por sua vez, costumam ser dirigidas aos membros de sua categoria social; nunca pudemos observar falantes jovens se dirigindo aos velhos presentes nas reuniões, exceto nos momentos de avaliação e de apresentação, a menos que o jovem seja, por exemplo, presidente da entidade ou coordenador de uma atividade de grupo, posição que o obriga a dirigir a palavra a todos os presentes. Via de regra, não se observam tumultos, nem manifestações de impaciência, impolidez ou disputas abertas pelo controle da palavra. Nas assembléias baniwa, todos se esforçam por aparentar calma, paciência e tranqüilidade na espera do momento certo para fazer suas intervenções; esta capacidade de autocontrole parece decorrer da intensa disciplina física e mental requerida na socialização dos membros masculinos do grupo, e está ligada às estratégias de prevenção do Manhene. 
A disposição física dos presentes segue uma ordem inversa: a diretoria se posta habitualmente à frente da platéia; os primeiros lugares na fila de assentos são ocupados pelos jovens escolarizados cuja função é registrar os eventos da assembléia; cada capitão costuma trazer ou enviar como representante um jovem parente escolarizado, capaz de preservar uma memória escrita das decisões da assembléia para que eles possam cobrar futuramente da diretoria os encaminhamentos combinados na reunião. Nos assentos do fundo ficam os capitães, ostentando um aparente desinteresse, mas de fato acompanhando atentamente o desenrolar das atividades, intervindo quando lhes interessa, quando são diretamente consultados pela diretoria ou no momento de tomada de decisão. Quando existem mulheres na assembléia, elas costumam ocupar os assentos do fundo, no lado direito do salão, numa disposição similar à que ocupam no salão de conferências. Essa disposição fixa dos participantes visa propiciar aos capitães o controle da participação dos jovens, pois ficando no fundo do salão os mais velhos conseguem acompanhar tudo o que ocorre no ambiente e verificar se a escrita está sendo feita a contento ou se os encarregados dela se distraem em conversas paralelas.

Em resumo, a ordem inicial de fala expressa o prestígio atribuído a cada subgrupo presente, e a disposição espacial dos assentos demonstra que a retaguarda é o espaço de poder de onde os velhos encaminham seus jovens representantes para a ação concreta na assembléia, fazendo um controle estrito sobre eles e intervindo apenas nos momentos decisivos, numa lógica interna de organização que mimetiza a interação de gerações nos antigos raids guerreiros. A diretoria da entidade tem um perfeito conhecimento dessas disposições subjacentes, pois seus esforços de convencimento e negociação são direcionados especificamente para o fundo do salão, onde serão tomadas as decisões-chave do evento.

A convivência cotidiana no mundo baniwa desperta a inquietante sensação de que ali todos têm um lugar definido na sociedade e de que todos 'sabem qual é o seu lugar' no mosaico caprichoso da hierarquia que ordena a vida social. É uma sensação enganosa, pois as transgressões e subversões do modelo ideal de comportamento são facilmente observáveis e os membros da sociedade se esforçam ativamente para limitar as oportunidades de disputas e confrontos, por meio do uso dessas estratégias de enquadramento e segmentação detalhada dos papéis sociais a serem desempenhados pelo indivíduo. Nas assembléias, reuniões e encontros religiosos, como as Conferências evangélicas, é possível observar a materialização dessa busca obsessiva da ordem e da classificação dos papéis sociais: no salão de eventos existem lugares definidos para serem ocupados por homens, mulheres, jovens, velhos, pessoas de maior e de menor prestígio; os locais de tomar banho, lavar roupa e de defecar também são rigidamente demarcados para cada sexo, sendo alvo de atenta fiscalização dos organizadores do evento. A 
diferenciação espacial de lugares e assentos materializa a distribuição hierarquizada das pessoas pelos diferentes nichos de poder contidos no espaço de reunião.

O espaço de poder configurado em torno da Organização Indígena está diretamente ligado à construção de um campo de conhecimento oriundo dos saberes e técnicas dos brancos, mas ainda está a serviço dos poderes dos velhos. As assembléias indígenas são momentos privilegiados de aprendizado do saberes não-indígenas; devido aos assuntos tratados, invariavelmente surgem idéias e conceitos desconhecidos por muitos dos presentes; tais temas podem variar desde coisas simples, como um algarismo romano que surge no título VII Assembléia anual da Oibi, até discussões complexas como a regulamentação do direito à exploração mineral presente na proposta de Estatuto do Índio, que hoje tramita no Congresso Nacional.

A influência hierárquica dos sibs na vida cotidiana não é consensual na literatura sobre os Baniwa; Journet (1995) afirma que ela tem expressão apenas ritual. A diferença com os dados encontrados nessa pesquisa talvez se deva ao tipo de análise feita. Se observarmos a questão a partir da ótica da vida da aldeia, marcada pelo ideal autárquico e pelo relativo igualitarismo nos modos de viver, não se observam formas evidentes de expressão dessas posições hierárquicas; ou seja, pertencer a um sib socialmente mais valorizado não gera mudança significativa na vida cotidiana e nas relações travadas entre as comunidades. O problema se evidencia quando olhado a partir da dinâmica desencadeada pelas relações de contato interétnico, particularmente aquelas travadas pelas Organizações Indígenas, que demandam a escolha de representantes de comunidades, habitantes de calhas de rio ou de grupo étnico, para atuar no conjunto de cargos e eventos que se geram a partir das atividades etnopolíticas.

Antes da consolidação do movimento indígena, as relações políticas entre as aldeias se orientavam principalmente pelas alianças de casamento e/ou consangüinidade e religiosidade. A entrada dos Baniwa no movimento gerou a necessidade de decidir 'quem nos representa' fora da área indígena e de definir critérios de orientação dessa escolha; com freqüência lhes é solicitado que elejam ou designem representantes para comparecer a reuniões, assembléias, negociar com autoridades não-indígenas, compor comitês, conselhos etc. A ocorrência de tais espaços de poder, anteriormente inexistentes, institui uma aliança 'Baniwa', um tipo de identidade genérica para representar um grupo muito amplo de sibse fratrias, relativizando a diferença constitutiva das identidades locais. Como resposta a este novo desafio, observa-se uma revitalização da hierarquia de sibs, tomada como um dos fatores de avaliação/definição de escolha de representantes e visando à obtenção de consensos capazes de contemplar os interesses e disputas dos grupos faccionais.

Diante das novas necessidades de decidir 'quem nos representa', estabelecem-se parâmetros que orientem tais decisões, e a posição hierárquica no sistema clânico é um dos critérios que transcende às rivalidades grupais. Igualmente 
se procede a uma revitalização da idéia de chefia como 'aquele que nos precede', a 'nossa cabeça', que toma a iniciativa nos processos sociais, favorecendo a escolha de representantes que pertençam a sibs prestigiados, identificados como produtores de chefes, responsáveis pelo encaminhamento de decisões. Talvez essa variável possa explicar também a inoperância de algumas organizações cujos presidentes são omissos ou despreparados para o exercício do cargo; nestas situações, mesmo na existência de outros membros qualificados e motivados na diretoria, observa-se uma tendência dos diretores se manterem em compasso de espera das decisões e iniciativas do 'cabeça' da Organização.

Ao se orientar pela consangüinidade e pelo controle das gerações mais jovens, o trabalho das Organizações Indígenas promove uma revigoração da etnicidade, sendo assimilado ao eixo vertical da sociedade baniwa, no qual se dá a reprodução das genealogias e a sucessão de gerações (Wright, 1981). Como estes elementos proporcionam um marco de orientação da relação líder-seguidor, a ocupação de cargos políticos por pessoas muito jovens, ocorrência comum na direção das Organizações de Base, subentende um certo grau de incoerência lógica que onera sua credibilidade com os mais velhos.

No eixo horizontal, representado pelas relações estabelecidas entre fratrias e aldeias geograficamente mais distantes entre si, distribuídas em microterritórios políticos situados entre o Alto e Baixo Içana e Aiari, o relacionamento costuma ser marcado pelas tentativas de reciprocidade negativa, como é comum entre afins. No âmbito da afinidade, o eixo de relações se dá entre sogro-genro-cunhado, respeitando também a precedência das gerações mais velhas sobre as gerações mais novas, ainda que não-consangüíneas.

As injunções da consangüinidade e da afinidade influenciam na eficácia social das Organizações Indígenas, que conseguem atuar de forma mais eficiente quando fundem seus rumos às matrizes demarcadas pelas interações hierárquicas de sibs, à sua distribuição territorial e às noções de senioridade estabelecidas para os membros de cada geração.

Trabalhando com os Amuesha, Granero (1994) percebe que naquele povo as relações entre irmãos não estão regidas por nenhuma forma de classificação hierárquica e por isso são relações mais expostas a conflitos e disputas. A noção rionegrina de irmão mais velho e irmão mais novo limita a possibilidade deste tipo de disputa, pois também estas relações estão regulamentadas na hierarquia generalizada; desse modo, as Organizações cujas bases são formadas apenas por consangüíneos podem, potencialmente, contar com mais apoio que aquelas formadas por grupos de cunhados. A hierarquia não resolve em si mesma o conflito, mas ameniza o potencial disruptivo de interações cotidianas, minadas por disputas.

Nas relações de afinidade existem campos não regulamentados pela hierarquia e o igualitarismo das relações frátricas produz um campo fértil para 
controvérsias; então, quando a área de abrangência política de uma Organização a obriga a lidar também com relações travadas entre fratrias diferentes, sua capacidade operativa tende a ser permeada pela desconfiança que permeia as interações entre afins; como a liderança tem de pertencer obrigatoriamente a um dos pólos desta relação, os eventuais conflitos produzem reflexos na sua credibilidade.

A variáveis como esta se ligam a disciplina, o respeito às regras morais, a capacidade de trabalho e o conhecimento da Bíblia, também muito importantes para os evangélicos na constituição dos critérios de legitimação das lideranças. 0 cumprimento dos valores morais priorizados na cultura baniwa pode não ser determinante para eleger um dirigente, mas é suficiente para inviabilizar o seu trabalho se, ao longo do mandato, ele demonstrar um comportamento incompatível com aquele considerado desejável. Os critérios de validação da legitimidade de uma liderança se ordenam na forma de 'status atribuído' - aquele que o indivíduo obtém a partir de sua posição de nascimento na estrutura social - e de 'status adquirido' - aquele que ele atinge através de seu próprio esforço e trabalho pessoal. A legitimidade resulta de uma distribuição equilibrada de requisitos de ambos os tipos (Kushinir, 1999).

Não há diferença essencial no que é cobrado da chefia de aldeia e das lideranças de Organização Indígena a quem são igualmente atribuídas funções de mediação, negociação e prevenção de conflitos e confrontos diretos no exercício de suas funções. De modo análogo lhes é censurada a liberação de paixões e hostilidade no seu meio social; a liderança deve obedecer à lógica da likoada e evitar que a própria violência ou a dos outros se espalhe no meio social. Nas formas de entendimento baniwa da realidade, os grupos que partilham relações de consangüinidade formam um todo indiviso, e a ameaça a um de seus membros pode facilmente atingir o restante do conjunto. Cada indivíduo tem a responsabilidade de autolimitar sua própria agressividade e de monitorar as manifestações hostis no conjunto do corpo social; o não-cumprimento desta obrigação pode redundar num retorno, sob a forma de infortúnio e doença, capaz de atingir qualquer membro do grupo de consangüíneos.

\section{Representatividade}

A Organização Indígena ocupa uma condição ambígua no mundo indígena, por ser um privilegiado veículo de captação de bens e prestação de serviços, oriundos principalmente dos poderes de Estado, e por se caracterizar como uma instituição sem equivalente nas formas habituais de organização social de sua cultura de origem. Gera-se, então, o risco permanente de autonomização da entidade e de sua transformação em uma burocracia indígena, que atue como 
um fim em si mesma, fora do alcance e controle das estruturas políticas que propiciaram sua existência.

Faz-se necessário se interrogar sobre os mecanismos de controle, acessíveis às forças comunais, da atuação da Organização Indígena e sobre que meios elas dispõem (ou não dispõem) para coagir lideranças a agir de acordo com os interesses dos grupos de poder a quem se propõem representar. O primeiro passo é problematizar as formas de representatividade exercida por lideranças que provêm de sociedades que não partilham a idéia de democracia representativa tipo grega. Aqui a noção de representatividade é radicalmente diferente da maneira como o termo é entendido no mundo ocidental; a idéia de delegação de autoridade e poder de decidir pelos representados é estranha à sua lógica interna. $\mathrm{O}$ chefe político indígena não costuma receber uma delegação de autoridade com alcance suficiente para tomar decisões que lhe confiram poder de intervir e mudar a realidade social de seus liderados e nem de garantir que suas decisões e acordos sejam cumpridos por aqueles que eles supostamente representam. Sua autoridade é centrada no uso da palavra e no poder de convencimento da justeza de suas proposições; não conduzem os liderados conforme seus desejos, mas enunciam propostas e pontos de vista que podem ser considerados, seguidos ou rejeitados por eles (Clastres, 1990).

As modernas lideranças indígenas também não detêm uma delegação de poder que lhes permita modificar a conduta de seus liderados ou de representá-los ante o mundo não-indígena; sua função é ouvir, entender, explicar e sugerir rumos a tomar, sobretudo no que se refere às complexas negociações travadas com a sociedade nacional (Bartolomé, 1995). Os líderes das Organizações de Base baniwa são "cultural brokers", agentes interculturais sem poder de mando, cuja delegação recebida se destina principalmente a uma intervenção intercultural mais eficiente no mundo não-indígena, veiculando demandas coletivas que ultrapassam os interesses individualizados de cada aldeia (Bartolomé, 1995).

\section{Formas de controle da Organização Indígena}

Vinculado ao domínio da palavra, o poder outorgado às chefias políticas indígenas se situa numa interface de injunções materiais, políticas e simbólicas, gerando um valor social que ultrapassa a mera capacidade lingüística. Para Pierre Bourdieu (1996a:53), "...os discursos não são apenas signos destinados a serem compreendidos, decifrados; são também signos de riqueza a serem avaliados, apreciados e signos de autoridade a serem acreditados e obedecidos". Assim, o manejo do discurso é um dos meios pelos quais as lideranças indígenas buscam ampliar seu capital simbólico e o poder potencial daí decorrente. A função mediadora da capacidade discursiva tem sido trabalhada na etnologia da chefatura indígena 
sul-americana por autores como Santos-Granero (1993, 1994), Rivière (1989) e Clastres (1982), para quem o domínio da palavra é uma das pré-condições do exercício da chefia.

No mundo das Organizações Indígenas, uma das formas de fazê-lo é mediante visita periódica às aldeias da área de abrangência da entidade. Este trabalho, denominado localmente de 'articulação política', é um elemento essencial para a manutenção da credibilidade e legitimidade dos líderes de base. Nessa ocasião, a liderança desenvolve um ritmo intenso de deslocamento fluvial para visitar cada aldeia de sua área de abrangência e cumprir uma pesada agenda de reuniões e conversas com os principais atores políticos das comunidades, divulgando o plano de atividades da entidade, detalhando encaminhamentos de atividades planejadas, tentando convencer sua base política da justeza de suas propostas, da honestidade de sua atuação e desmentindo boatos que lhe sejam desfavoráveis. Através do contato face a face, a liderança de Organização Indígena, nem sempre presente no dia-a-dia da aldeia, compete no mercado simbólico ${ }^{53}$ local, tentando produzir verdades e inteligibilidade à sua versão dos eventos políticos. Trata-se de relações de comunicação que implicam o conhecimento e reconhecimento de diferentes interpretações da realidade; são formas de poder simbólico que atualizam relações de força entre grupos; por meio delas aqueles que, por intermédio de atos extralingüísticos, acumularam suficiente capital simbólico, exercitam a capacidade de "fazer crer" nos seus projetos políticos e nas suas propostas de atividades (Bourdieu, 1989).

A visita periódica às bases representa uma reafirmação do vínculo e do interesse pelo mundo da aldeia; é uma prova de que a liderança náo iniciou uma diferenciação inaceitável ante o comportamento cotidiano da população aldeada. O contato reafirma seu compromisso público com os interesses e necessidades indígenas e demonstra que a liderança não 'virou branco', a grande acusação que pesa sobre qualquer pessoa que assuma funções institucionais não-indígenas. Além disso, os Baniwa valorizam muito o contato pessoal: para eles o 'olho no olho' é um elemento essencial de avaliação das intenções do interlocutor e permite atestar a coragem para encarar as eventuais críticas das lideranças mais velhas; além disso, permite uma avaliação in loco do seguimento das regras de cortesia e do comportamento que a liderança de Organização vem adotando na sua interação com as chefias mais velhas.

A articulação é ampliada com o estabelecimento de rede de radiofonias que permite a troca diária de idéias, o confronto de versões, a circulação de boatos e a recepção de informações sobre os eventos que ocorrem no mundo dos brancos. Atualmente, a diretoria da Foirn tem restringido o financiamento das atividades de articulação, o que é visto como um potencial comprometimento da confiabilidade do trabalho das Organizações de Base. 
A credibilidade adquirida pela liderança deve ser entendida como resultado da participação num cenário social onde se disputam sentidos. Situados na confluência de disputas infindáveis, os diretores das Organizações estão sempre tentando fazer valer suas versões e explicações sobre os eventos que se sucedem, num espaço simbólico onde todos buscam tornar hegemônica sua própria interpretação dos fatos e disso auferir ganhos políticos. Se a liderança não consegue adeptos para apoiar suas formas próprias de ver o mundo e agir sobre ele, pode terminar isolada ou ser vítima de uma campanha de acusações, cuja veracidade ou falsidade não faz muita diferença quanto ao seu efeito final, a recategorização de 'boa' para 'má liderança', com a subseqüente queda.

A eficácia social do boato deve ser buscada nas suas condições de produção e circulação, sua força demonstra que ele não é um mero comentário ou juízo de valor; caso seus enunciantes sejam considerados mandatários legítimos da palavra, com capacidade de obter (ou produzir) uma correspondência entre a mensagem veiculada e a realidade sociológica, o boato adquire eficácia suficiente para produzir conseqüências concretas no meio social, produzindo realidades que ultrapassam sua origem lingüística (Bourdieu, 1996a).

Uma vez desencadeado, o boato ganha uma força quase incoercível; atualmente ele é potencializado pela rede de radiofonia, o que the permite ultrapassar, embora não substituir, o alcance dos comentários face a face. Em muitas situações, o boato é deliberadamente manejado pelos capitães em busca de proveito político; em outras ele ganha autonomia própria, cabendo ao chefe da aldeia apenas se curvar ao mesmo, sob pena de comprometer também a própria credibilidade entre seus liderados. A refeição comunal diária é um momento crucial para alimentar ou refutar os boatos; nela o capitão avalia cuidadosamente a correlação de forças entre seus liderados e eventuais desafetos e busca reforçar sua própria posição política no grupo. Nesse âmbito, o capitão goza de um poder diferenciado, pois detém o monopólio da convocação da refeição comunitária e pode, de acordo com seus interesses, beneficiar grupos de aliados franqueando ou esvaziando as falas dos homens presentes.

De que tratam afinal os boatos que constroem ou arruínam reputações? Seu tema principal parece ser a censura ante uma suposta apropriação desigual de bens e privilégios.

Tem capitão que é firme; fica sabendo o que está acontecendo e, se não gostar (da atuação da liderança de Organização Indígena), vai lá na Federação e acusa, acusa que ele está ganhando dólar através de você, através da comunidade; depois volta na comunidade e transmite na fonia, fala pras pessoas que ele é assim e assado. Aí pronto, as pessoas escutam esse boato e a gente conversa, conversa; daí ele vai caindo, caindo e depois ninguém mais escolhe ele... (V. P., capitão Dzawenai, católico) 
Como a sociedade dispõe de pouco poder de coerção sobre eventuais transgressores, o boato se mostra um eficiente meio de controle moral e de desempenho do trabalho de lideranças. Uma de suas principais conseqüências é o incremento da ameaça de envenenamento. O Manhene deve ser encarado como um instrumento inerente ao jogo político, particularmente entre afins, sendo a contrapartida lógica, na forma de vingança, de um comportamento individualista, que gera uma apropriação de bens e poderes em detrimento do grupo. O Manhene é a expressão anti-social da likoada, é um tipo extremo de reciprocidade negativa.

Mesmo detendo um considerável grau de autonomia, as Organizações são controladas pelas estratégias que buscam inibir a diferenciação entre os indivíduos; tais mecanismos, ampliados pelo uso da radiofonia, promovem a circulação dos boatos que forçam a liderança a explicar e justificar suas ações (e limitar sua autonomia) nas reuniões, assembléias e conferências que ocorrem ao longo do ano nas aldeias. Acusações de desvio de verbas, abuso de álcool, de adoção de padrões autoritários de comportamento ou similares aos modos dos brancos existem, e algumas vezes são fundamentadas, mas as relações de poder locais têm sido fortes o suficiente para impor uma rotatividade das lideranças acusadas. Na ausência de outras forças capazes de obrigá-las a executar corretamente suas tarefas e garantir o cumprimento das obrigações redistributivas (likoada), a publicidade da vida tribal se torna o principal meio de coação moral sobre a atuação dos líderes de Organização Indígena. O receio do veneno, do ciúme, das inimizades força muitas lideranças a 'andar na linha'; o poder individual dos velhos sobre os jovens líderes é frágil; somente sua potencialização, através da rede de interações políticas entre as aldeias, é capaz de produzir obediência às regras da sociedade, mesmo quando atuam no mundo não-indígena.

Um dos pontos que dificulta o controle sobre as Organizações Indígenas é o desconhecimento, pelas chefias de aldeia, das nuances burocráticas que envolvem o dia-a-dia da administração da entidade. Um controle adequado exige o entendimento de regras eleitorais, estatuto, $\mathrm{CNPJ},{ }^{54}$ prestação de contas, realização de assembléias etc. No momento atual, os dirigentes de uma Organização dispõem, caso o desejem, de um grande espaço de manobra para obtenção de um maior manejo sobre o processo político e para se manter fora do alcance dos poderes oriundos das aldeias. Como já se disse, as formas mais eficientes de controle ocorrem fora das instâncias burocráticas, operam no âmbito das sanções morais, que, no caso baniwa, estão intrinsecamente ligadas à religiosidade, ao messianismo e à produção social de doença.

A movimentação política da Organização estimula a consolidação da trajetória de personagens que se individualizam e tendem a se destacar do corpo social, criando-se uma contradição com processos sociais fundados no pensamento de tipo selvagem, no qual se admite a diferenciação de grupos sociais, mas se desestimula 
a diferenciação dos indivíduos no interior da sociedade (Lévi-Strauss, 1976). Ao longo de sua existência, as etnias rionegrinas desenvolveram fortes mecanismos de combate às diferenças não inscritas na lógica da diferenciação de sibs e fratrias, fundada na hierarquização de papéis e posições rituais que ordenam a vida social; a ruptura com tais mecanismos costuma redundar em conflitos e sanções que terminam por inviabilizar a carreira política da liderança.

Construídas a partir desses critérios, legitimidade e representatividade de Organizações de Base se ampliam na medida em que elas consigam mimetizar formas de atuação políticas preexistentes e já praticadas pelas chefias de aldeia de sua área de abrangência. Apesar de lidarem com temáticas mais ligadas ao mundo extraaldeia, as lideranças fazem um ativo processo de ancoragem, ${ }^{55}$ incorporando técnicas. institucionais não-indígenas, mas adaptando-as às suas formas próprias de pensar e intervir no mundo. Esses atores sociais não se comportam de forma meramente reativa à dominação gerada pelo contato interétnico, mas, agindo conforme suas próprias "leis de movimento", buscam uma ativa transformação de sua cultura incorporando "...a experiência do sistema mundial em algo que é lógica e ontologicamente mais inclusivo: seu próprio sistema de mundo" (Sahlins, 1988:51).

\section{Política e reciprocidade}

As obrigações de reciprocidade se atualizam na atuação das Organizações Indígenas, mas simultaneamente produzem um reforço nas ordens hierárquicas previamente estabelecidas, na medida em que os novos cargos e papéis (agente indígena de saúde, professor, pessoas de maior escolaridade) tendem a ser ocupados por aqueles que já estavam no topo da hierarquia dos sibs e que são instados não apenas a conservá-los, mas também a manter as obrigações redistributivas. 0 processo produz o que Sahlins (1983:227/228) chama de "efeitos redundantes sobre o sistema de hierarquias", no qual a capacidade de reunir um grupo de seguidores e obter prestígio e fama é mediada por uma generosidade calculada e dirigida a esta finalidade. Assim, a liderança de Organização Indígena precisa estar atenta ao cumprimento das obrigações redistributivas em relação aos seus consangüíneos, sob pena de descrédito e acusações que redundarão em prejuízo político; neste nível, a atuação da liderança indígena está intrinsecamente ligada às obrigações morais e políticas do parentesco.

A legitimação da liderança é sempre frágil, pois nada garante que as forças políticas das aldeias retribuam seus bem-sucedidos esforços à frente das entidades. Como seu desempenho também é mensurado segundo parâmetros congruentes com as regras de reciprocidade, se o líder passa a ser identificado como alguém que fracassa repetidamente em obter bens e prestígio ou se, ao 
obtê-los, os retém para si, o troco virá na forma de denúncias e descrédito, culminando com sua não-indicação para cargos eletivos futuros.

$\mathrm{O}$ agente de saúde é representado socialmente e nomeado como ithapetakaita, 'aquele que dá remédios'; a atividade está inserida no circuito de reciprocidade: a sociedade o designa para ocupar cargo politicamente prestigioso e, em troca, ele deve retribuir com bens e serviços. Os medicamentos manejados pelos agentes de saúde estão permanentemente na mira dos mais velhos; a lógica técnica, sob a qual os agentes de saúde foram treinados pelas instituições de saúde, diz que remédios se destinam àqueles que apresentem sintomas específicos de doença; a lógica comunitária, que os incorpora ao conjunto de bens disponíveis, indica que medicamentos devem circular segundo as regras de reciprocidade e não segundo necessidades biomedicamente determinadas (Garnelo, 2001a).

Na ótica dos profissionais de saúde, a distribuição de bens sanitários (remédios, consultas, combustível para remoção de doentes etc.) faz parte de um direito de cidadania, desfrutável pela simples condição de nascer e viver no País; para os índios são bens distribuídos por um chefe (o Estado, o dirigente da Fundação Nacional de Saúde - Funasa etc.) que finalmente começa a cumprir com suas obrigações de generosidade redistributiva. Na ótica indígena, tais bens se destinam a uma distribuição equânime a todos os grupos que constituem o corpo social tal como se espera que um bom chefe o faça; já a razão técnica, partilhada por mediadores indígenas como os agentes de saúde, conselheiros de saúde e líderes de Organização Indígena, diz que o rádio ou o motor de popa se destinam ao pólobase $^{56}$ ou a pontos de apoio à remoção rápida de doentes.

Se os mediadores do contato interétnico passam a utilizar uma lógica das instituições do branco, que aprendem a conhecer e à qual se submetem e/ou aderem, por apreenderem sua coerência interna, a tendência dos capitães é buscar e obter bens e serviços para os seus próprios co-residentes; de modo geral estes não partilham as orientações técnicas das instituições do branco e, quando as conhecem, nem sempre concordam com elas, particularmente quando ferem seus interesses políticos.

Para os capitães, o perigo de traição ao princípio da reciprocidade pelas lideranças das Organizações é constante, sempre havendo a possibilidade de subtração, para uso próprio, de uma parcela de bens que se destinariam ao corpo comunal, o que pode explicar o controle férreo, que os mais velhos fazem, sobre a potencial apropriação de bens pelos agentes da modernização (Garnelo, 2001a). A vigilância sobre os mediadores interculturais pretende evitar que eles atendam demais a racionalidades estranhas às prioridades políticas dos sibs e tenta conduzilos a um projeto político que, mesmo se utilizando de instrumentos e meios políticos 
oriundos das relações de contato, se mantenha fiel aos pressupostos e valores do mundo indígena (Turner, 1993a).

O desafio atual das Organizações Indígenas não é romper com essa lógica, mas inserir no universo das relações de reciprocidade a idéia de 'projeto', na qual a contraprestação feita pela entidade não se faz em bens, e sim no favorecimento das relações de trabalho, e/ou de prestação de serviços de educação, saúde e outros capazes de alterar positivamente, num prazo mais alongado, as condições de vida de seus liderados. A exigência de generosidade da chefia é mantida, o que muda é o objeto dela; a polêmica que se estabelece gira principalmente em torno do alcance da retribuição feita pela liderança, pois tanto os parentes mais próximos quanto os mais distantes pressionam para maximizála em seu próprio favor, ameaçando com o ciúme e o boato, caso a redistribuição não ocorra de forma satisfatória.

Tais idéias contradizem os princípios do pan-indigenismo, que concebe os índios como estabelecendo obrigatoriamente relações de fraternidade e solidariedade entre si, mantendo um compromisso moral e solidário a priori com a causa indígena, desconsiderando as nuanças que envolvem as relações intra-étnicas. No conjunto das relações de reciprocidade devem ser incluídas também as relações travadas com o branco, que representa um tipo mais extremo de não-parente, o que acirra a suspeita, a desconfiança e as mútuas tentativas de reciprocidade negativa, apesar da assimetria de poder que tão obviamente favorece o branco.

Esse tipo de raciocínio pode ser estendido para a atuação da Organização Indígena. Quando a área de abrangência da entidade recobre, como é o caso atual da Oibi e da Oicai, aldeias geograficamente próximas, pertencentes ao conjunto de sibs que guardam laços de consangüinidade entre si, maximiza-se o surgimento de relações equilibradas de reciprocidade, viabiliza-se um controle maior da atuação das lideranças pelos membros das comunidades e um trabalho mais centrado nos interesses coletivos. As Organizações que se propõem a atuar em regiões geopolíticas muito amplas, muito distantes entre si, congregando afins e consangüíneos entre suas bases, enfrentam um difícil clima de hostilidade e desconfiança, tendo sérias dificuldades em obter organicidade e credibilidade em sua ação política. Tais premissas têm conseqüências para um rumo geral do movimento indígena porque parecem indicar a necessidade de recortar seu espaço político de atuação em microunidades, que sigam mais a lógica da organização do parentesco do que a idéia de abrangência geográfica típica das instituições políticas do mundo do branco. 


\section{O Dia-a-Dia das Organizações Baniwa de Base}

Para Granero (1994), a autoridade política indígena se expressa mediante o parentesco, na relação entre um líder e seus seguidores, que deve ser entendida como se fosse uma relação entre um pai e seus filhos, reais ou classificatórios. $O$ outro fator sobre o qual o exercício do poder se fundamenta são as relações de troca/reciprocidade, feitas prioritariamente entre consangüíneos. Entre os povos rionegrinos também é a consangüinidade que proporciona a metáfora para expressar as relações de poder; a aliança entre irmãos do sexo masculino é a base a partir da qual se configura a manutenção do poder político, o que pode ser confirmado na tendência das Organizações Indígenas em formar diretorias com a presença de dois ou mais irmãos; o nepotismo representa, aqui, uma forma de garantir alianças harmônicas na condução dos objetivos políticos da entidade; por outro lado, relação de afinidade costuma se caracterizar pela desconfiança, a disputa e o estranhamento que, entre os Baniwa, se expressam de forma extremada no uso do Manhene.

Proposições teóricas como esta podem ser ilustradas no entendimento do papel do 'conselheiro' de Organização de Base. A criação deste cargo ocorreu inicialmente na Foirn, por exigência legal para reconhecimento da entidade e, a partir daí, foi sendo reproduzida para as Organizações de Base que se formaram nos momentos subseqüentes. Na estrutura da Foirn, o conselho fiscal é composto por representantes das diversas sub-regiões políticas que compõem a federação, exercendo uma função similar a dos conselhos fiscais sindicais, ou seja, aprovar o planejamento e a prestação de contas anuais. Nas organizações baniwa, tais funções foram redimensionadas; no geral o conselho se resume a um ou dois indivíduos, escolhidos entre os membros mais velhos e respeitados das comunidades; eles devem, preferencialmente, pertencer a um sib entre cujas antigas funções estava a de 'aconselhar' os mais jovens, apoiar o trabalho de chefia e transmitir orientações de comportamento às pessoas comuns da maloca.

Nas entidades de base, as principais tarefas deste personagem são as seguintes: orientar os jovens dirigentes quanto a eventuais transgressões de valores morais, intermediar suas relações com os velhos capitães, apaziguando eventuais conflitos, fornecendo exemplos de bom comportamento social e zelando pelo cumprimento das regras vigentes. Como o domínio da língua portuguesa e a escolaridade dessas pessoas costumam ser restritos, elas não teriam os requisitos necessários para exercer o controle fiscal, que seria a função precípua de seu cargo; entretanto tal não lhes é solicitado: a sua função é a de mediar o contato entre os grupos de idade que intervêm na vida política das aldeias. Trata-se, portanto, da ressignificação de uma função institucional não-indígena que é reacomodada a um papel reconhecido e valorizado desde os períodos anteriores ao contato. 
Tomando como exemplo a Oibi, observa-se que, nos dois primeiros mandatos da entidade, o capitão koteroeni, cuja atuação foi decisiva no episódio de enfrentamento da mineradora Goldamazon, desempenhou a função de 'conselheiro', assumindo posições públicas de defesa e divulgação dos objetivos da entidade, exercendo uma influência que foi decisiva para a aceitação da Organização. Esse personagem resgatou uma das funções tradicionais de seu sib: falava para as chefias de aldeia em nome do presidente, walipere dakenai que, por sua juventude e inexperiência, tinha menores chances de ver suas propostas ouvidas e acatadas. Ele emprestou, nos primeiros tempos da entidade, legitimidade aos diretores, convencendo outros mais velhos a apoiar o difícil começo de uma agremiação desprovida de quaisquer meios de atuação política e material. Pode-se dizer que a legitimidade obtida inicialmente pela Oibi foi concretizada através da ação de seu 'conselheiro', que gozava de um prestígio adquirido em vivências políticas anteriores, que independiam do movimento indígena.

Depois de uma trajetória de nove anos de trabalho, a diretoria da entidade adquiriu legitimidade suficiente para falar e ser ouvida pelos mais velhos, sendo possível dispensar, dentro de certos limites, a intermediação do conselheiro. A vantagem de posição de nascimento dos membros da Oibi, aliada ao bem-sucedido trabalho de seus dirigentes, gerou um acúmulo de capital simbólico suficiente para neutralizar uma posição desfavorável na hierarquia de idades. Por outro lado, eles conseguiram acumular capital econômico, ${ }^{57}$ representado pelos bens materiais da Organização, mas têm sido, até o momento, capazes de demonstrar para seus liderados que o usufruto desses bens tem se dado de forma coletiva e não de modo privado, o que vem contribuindo para manter o apoio político de suas bases.

A análise do relatório de atividades da Oibi para o ano de 2000 mostra um conjunto de ações nas áreas de Educação, Saúde e Alternativas Econômicas, dirigidas às comunidades de sua área de abrangência.

No campo da Educação, a atuação da entidade se volta principalmente para a implantação da Escola Indígena Baniwa e Curipaco, que tem por objetivo oferecer educação formal, na área indígena, até a $8^{\mathrm{a}}$ série. A escola funciona por meio de relação de convênio com a Secretaria Municipal de Educação de São Gabriel da Cachoeïra, mas seu eixo político gira em torno da busca de desenvolvimento de uma proposta educativa etnicamente diferenciada e de preparar quadros nativos para a condução futura do movimento indígena local.

Outra área de atuação da Oibi, que constitui atualmente sua iniciativa mais visível e seu empreendimento de maior sucesso, é o projeto de comercialização de cestaria baniwa produzida por artesãos indígenas. O projeto de artesanato materializa uma resposta da Organização a uma das maiores demandas das comunidades, que é a geração de renda. Depois de quase três anos de penosas tentativas, a diretoria da entidade, com a ajuda de parcerias não-indígenas, 
conseguiu colocar peças de cestaria no mercado nacional, obtendo um preço bem melhor que aquele habitualmente pago no mercado local de São Gabriel da Cachoeira. O desenvolvimento do projeto de artesanato exigiu um detalhado aprendizado de como desenvolver pesquisas de mercado, traçar um plano de comercialização, viabilizar a produção de peças capazes de atender às exigências de mercado, capacitar artesãos para desenvolvê-las de acordo com as especificações dos compradores, implantar um sistema de escoamento capaz de recolher os cestos nas aldeias, efetuar o pagamento dos impostos e taxas de comercialização e transportar a mercadoria até os compradores em outros estados e no exterior, em tempo hábil para atender ao cronograma previamente combinado.

Internamente, o projeto de artesanato vem produzindo renda para os artesãos, favorecendo a entrada de recursos para cobrir os custos de produção e propiciando um incremento da credibilidade política da Associação, cujas atividades aliam o desenvolvimento de projetos de auto-sustentação com bandeiras políticas mais gerais como a organização de uma futura federação baniwa. Os recursos auferidos com a venda de artesanato também têm permitido manter um intenso trabalho de articulação política entre as aldeias, reuniões e assembléias periódicas com as chefias políticas locais, além do custeio da infra-estrutura e manutenção administrativa da entidade.

Uma das mais importantes conseqüências locais do sucesso do projeto de artesanato foi a superação do modelo de aviamento. Até pouco antes de sua implementação, havia uma forte expectativa de revitalização do mesmo; apesar de cientes do endividamento gerado, a médio prazo, pelo sistema de crédito do aviamento, as pessoas esperavam pelo aparecimento de um 'patrão' que lhes possibilitasse novamente o acesso às mercadorias. Na ausência de comerciantes interessados nos produtos oferecidos pelos indígenas, havia forte expectativa de que a Oibi assumisse o papel de 'patrão'.

Um penoso trabalho político foi o de convencer os comunitários da inviabilidade do adiantamento de mercadorias, em troca de produção futura de artesanato. A Oibi estabeleceu como protótipo de comercialização a venda à vista, adaptada às condições locais, ou seja, o artesão fornece as peças para a entidade que recolhe numa só viagem toda a produção; esta, por sua vez, é vendida e no final da operação comercial o dinheiro entregue em mãos do produtor, de acordo com o número de peças produzidas. É uma operação aparentemente simples, mas propicia ao produtor um controle sobre o produto de seu trabalho, pois ele deixa de comprar mercadorias impostas pelos comerciantes com os quais tinha relações de endividamento, ficando livre para estabelecer transações que lhe sejam mais favoráveis; por fim, ela desmonta o sistema de relações de deferência, obrigações e endividamento progressivo que sempre cercaram as relações aviador-aviado. 
No árduo caminho da autogestão, as estratégias do cooperativismo e regras da economia de mercado se juntam às disputas do parentesco, misturando-se ainda às desconfianças entre consangüíneos e afins, entre produtores e comerciantes. A fusão de localismos e globalismos traz a lógica do sofisticado mercado de produtos de selo étnico para o campo das disputas fráticas baniwa.

O terceiro locus de atuação da Oibi é o trabalho de saúde, no qual as principais ações têm sido o apoio ao trabalho dos agentes indígenas de saúde e uma intensa participação nos conselhos de saúde, nos quais se exerce o controle social ${ }^{58}$ sobre as atividades sanitárias, destinadas à população indígena do Alto Rio Negro. As lideranças da Oibi e da Acira têm investido boa parte de seu tempo e esforço para aprimorar o funcionamento dos conselhos de saúde da área baniwa, construir uma participação qualificada e informada e disseminar, entre os mais velhos, os projetos e propostas para a melhoria das condições sanitárias nas áreas indígenas. As lideranças baniwa vêm exercendo cargos de coordenação nos conselhos de saúde e participando ativamente da formulação, acompanhamento e avaliação dos planos de saúde.

A atuação no campo de políticas de saúde, além de contribuir para reafirmar a legitimação da entidade, também favorece a articulação política entre seus dirigentes e chefias locais, pois o controle social em saúde se caracteriza por um grande número de encontros e reuniões, que são devidamente aproveitados pelas lideranças indígenas também para a discussão de outros temas 'não sanitários', facilitando a tomada coletiva de decisões.

Como último eixo da ação da Oibi no campo da saúde, assinala-se o Projeto de Medicina Tradicional Baniwa. Um balanço político geral dessa atividade mostra um redimensionamento do papel das gerações mais velhas ante o trabalho sociossanitário dos agentes de saúde e líderes de Organizações Indígenas, cuja atuação em campos de saber exteriores à cultura baniwa limita as formas comunitárias de controle sociopolítico sobre seu trabalho. Na contramão da ordem social baniwa, o domínio de saberes não-indígenas tende a favorecer a autonomização dos mais jovens; neste caso, as atividades do Projeto de Medicina Tradicional Baniwa e Curipaco propiciaram um importante revés nesta situação, ao valorizar os saberes das gerações mais velhas e reaproximar os jovens dos preceitos de sua cultura. Ao chancelar uma atividade que a coloca numa interface direta com os velhos, muitos dos quais não-evangélicos, a Oibi promoveu uma demonstração concreta dos objetivos agrupados sob a bandeira genérica de luta pelos direitos à diferença étnica e à preservação da cultura tradicional.

A análise do conjunto de atividades desenvolvidas pela Oibi mostra que seus dirigentes a estão conduzindo de forma a desenvolver a prestação de um conjunto de serviços e funções de políticas públicas que não são implementadas pelos órgãos pertinentes. A pauta de sua assembléia do ano de 2001 demonstra a 
tentativa de equilíbrio entre o que Albert (2000) chama de "Etnicidade política" e "Etnicidade de resultados", congregando temas de interesse imediato de suas bases, como o preço da passagem no barco da associação e a formação de um fundo destinado ao conserto de motores e radiofonia; temas intermediários, como a avaliação do projeto educativo da Escola Baniwa e do funcionamento dos conselhos de saúde, são também tratados ao lado de questões muito amplas, como os direitos de mineração no novo Estatuto dos Povos Indígenas e a proposta de criação do Território do Rio Negro.

O plano de trabalho da entidade para o triênio 2001-2003 também segue lógica similar, pois alinha propostas rotineiras, como as regras de funcionamento da Escola Baniwa e os rumos do Projeto de Medicina Tradicional, com questões de interesse geral, como a participação dos Baniwa em projetos de manejo ambiental e geração de renda e na política de implantação dos Distritos Sanitários Especiais Indígenas; dele ainda constam propostas de capacitação de lideranças para gestão de associações comunitárias e para a participação nos fóruns de política indígena.

A entidade vem priorizando atividades cada vez mais direcionadas para a implantação de ações de políticas públicas, particularmente nos campos da saúde, educação e auto-sustentação, buscando responder, ainda que parcialmente, às demandas concretas por melhoria das condições de vida. Os condutores desta política demonstram pleno conhecimento das limitações de sua atuação, por estarem substituindo o papel de um Estado omisso; entretanto eles valorizam uma ação propositiva como a participação no desenvolvimento de políticas públicas, ainda que para suprir lacunas na sua implementação. Tais alternativas são consideradas como uma inserção que poderá lhes permitir, no futuro, uma legitimação perante a sociedade brasileira e uma apropriação de políticas setoriais, a partir das quais possam sair da condição de receptores passivos e prejudicados - que apenas sofrem os efeitos das políticas públicas geradas no contato interétnico - para a posição de quem nelas pode intervir.

Em contraste, Acira tem que lidar com uma realidade bem diferente, pois enfrenta dificuldade em se legitimar com suas bases políticas, formadas por fratrias diversas, que também praticam diferentes religiões, gerando-se um clima de tensão que vem inviabilizando politicamente a entidade.

Os principais pólos de prestígio político no Aiari são as aldeias hohodene de Uapuí e Ucuqui, depositárias de saberes e práticas xamânicas e de benzimentos, que vêm tendo sucesso na obtenção de bens e prestígio; outrora, apesar da presença de seus xamãs, elas conseguiram estabelecer relações privilegiadas com a missão católica, o que atualmente vem sendo feito através de vínculos com a Prefeitura de São Gabriel, onde conseguem algumas melhorias sociais, o que agrava a desvalorização do movimento indígena. Os laços com a política populista da Prefeitura seguramente dificultam o estabelecimento das formas próprias de atuação 
do movimento indígena, pois as sucessivas diretorias da Acira não têm recebido apoio dos detentores de poder esotérico e nem os têm convencido de que a Organização Indígena pode se constituir numa alternativa viável às interações com o poder público municipal.

No momento atual, o desgastante trabalho de permanecer à frente de uma entidade com fraco poder de intervenção social parece não ser considerado compensador pelos sibs mais prestigiados da fratria Hohodene. Os católicos do Aiari são altamente desinformados e desarticulados politicamente, situação que é agravada pelo reduzido número de aparelhos de radiofonia, dificultando a disseminação de informações.

As aldeias evangélicas Walipere do Rio Aiari, embora em menor número, têm uma agressiva política de demarcação de sua identidade e se esforçam por acompanhar e influenciar os rumos dos eventos políticos que envolvem a população local. Entre os evangélicos, as Conferências e Santas Ceias facilitam a definição de posições e de bandeiras comuns - sem que se negue também a existência de conflitos latentes que podem explodir nessas ocasiões - conferindo-lhes, apesar do reduzido número, uma vantagem em relação aos católicos, que dispõem de poucas ocasiões para se reunir.

A primeira diretoria da Acira foi constituída basicamente de membros de sibs Hohodene, de Ucuqui, com a participação minoritária de membros de sibs Walipere de outras aldeias. Essa diretoria, que durou apenas dois anos, se autodissolveu, por alegada incompatibilidade entre suas funções como a de professores e as crescentes atividades, não-remuneradas, de líderes de Organização Indígena envolvidos com a intensa atividade da demarcação de terras. Outra razão da insatisfação da diretoria era a ausência de recursos próprios da entidade, o que demandava investimento de seus recursos pessoais para custeio do trabalho da associação. Opositores Walipere (do Aiari) dessa diretoria de Hohodene alegam que ela foi destituída por insatisfação dos capitães das outras aldeias, pois a entidade não apresentava, a seus olhos, resultados positivos, e os parcos recursos captados na Foirn eram redistribuídos apenas para a base comunal/familiar dos membros da diretoria, não havendo redistribuição para outras aldeias.

A segunda diretoria seguiu trajetória semelhante, visto que seus diretores sofreram, ao longo de seu mandato, pesadas críticas dos capitães que também reclamavam de sua não-produtividade. As censuras das chefias de aldeia giravam principalmente em torno da falta de resultados práticos do trabalho da Associação, que, em sua ótica, deveria redundar na obtenção de produtos industrializados ou formas de geração de renda. A frustração dos capitães, se expressando como descrédito no desempenho das lideranças, deve-se ao desejo de que a entidade ocupe a lacuna deixada pela não-implementação de políticas públicas, uma 
expectativa que não pode ser suprida por uma entidade incipiente como a Acira e provavelmente por nenhuma Organização Indígena.

No caso do Rio Aiari se estabelece um ciclo vicioso: sua Organização tem pouca credibilidade e apoio das bases, chegando enfraquecida na Foirn e tendo então dificuldade em conseguir bens e recursos que poderiam melhorar sua aceitação entre os capitães; essa dinâmica perpetua o circuito de baixa credibilidade, nível insuficiente de organização, dificuldade de captar recursos etc. A isso se adicionam as linhas de tensão entre crentes e católicos; sendo católica, a diretoria poderia contar com uma base de apoio potencial entre as aldeias católicas, mas, como se viu, este grupo desempenha um papel de adversário político não emprestando prestígio e credibilidade junto ao conjunto das forças políticas do Aiari; a presença dos poderosos sibs Hohodene na Acira opera apenas como uma reserva de controle político sobre os rumos da mesma.

Os sibs evangélicos, por sua vez, tendem a praticar um alinhamento automático contra as iniciativas vindas dos católicos. A religião dos dois principais diretores os torna alvo de uma dupla desconfiança, pois, além de serem da etnia Cubeo, numa área sob controle político dos sibs Hohodene, são também católicos e, portanto, suspeitos, aos olhos dos crentes, de fazer uso de bebida alcoólica e de participar de festas e rituais rejeitados pelos evangélicos. A reserva dos crentes pode se traduzir em agressões semiveladas, como danos ao motor de popa de propriedade pessoal de um dos diretores.

Acrescentem-se as tensões entre os três grupos de afins (Cubeo, Hohodene e Walipere), que formam a base política da entidade; temos um quadro político complexo e de difícil gerenciamento, o que pode explicar as grandes dificuldades enfrentadas pela Acira desde sua fundação, obrigada a gerenciar tensões muito anteriores ao estabelecimento do movimento indígena na região. A partir da condição de minoria étnica, seus diretores mais atuantes, que são Cubeo, enfrentam a difícil missão de negociar interpretações e intervenções sobre a realidade, dispondo apenas de uma escassa delegação de poder para construir um montante de capital simbólico suficiente para sustentar viabilidade institucional da Organização, convencer seus liderados da adequação dos sentidos que atribuem à realidade e conduzir um consenso que os habilite a falar em nome de todos (Bourdieu, 1996a).

A atuação do movimento indígena baniwa mostra uma forte imbricação entre o geral e o particular, que é produzida por pessoas que residem em aldeias nos altos rios, mas simultaneamente navegam na Internet, militam em partidos políticos, negociam com autoridades do Banco Mundial, participam de Conferências Nacionais de Saúde, enfim, gerenciam a coexistência de padrões ocidentais de organização política com uma aproximação deliberada dos fundamentos da vida tribal. Sua atuação se pauta na idéia de que a vida social 
se funda no ato de dar e receber, e de que relações políticas só se legitimam quando garantem o acesso de todos às fontes de poder, o que é viabilizado mediante processos redistributivos generosos. A violação destas normas gera o risco de retorno ao período caótico ancestral, em que o assassinato, o ódio, a cobiça e a avareza impossibilitavam o estabelecimento da vida social. A atuação da liderança deve ser entendida como uma forma de moralidade positiva, comportando singularidades explicáveis apenas pela forma específica como a cultura indígena influi sobre a mesma. Assim, o movimento indígena baniwa só adquire sentido pleno ao inteligirmos as relações de reciprocidade que fundam e garantem a existência da sociedade que o fez nascer.

Para finalizar, queremos assinalar o caráter instável da realidade flagrada pela pesquisa. No passado, a hierarquia dos sibs expressava mais uma especialização de papéis do que uma posição privilegiada na sociedade; hoje isto se atualiza por intermédio da ocupação de cargos remunerados, e a posição de prestígio deixa de se exercer no contexto economicamente igualitário da aldeia, passando a implicar maior acesso aos bens industrializados e conquistas decorrentes de políticas sociais. $\mathrm{O}$ contato interétnico tem a potencialidade de transformar uma posição de prestígio simbólico em posição de mando e acúmulo de capital econômico, possibilitando a um grupo restrito o acesso privilegiado a bens e serviços não disponibilizados para todos os membros da sociedade.

Some-se a isso a mudança que se gesta em uma das categorias mais fundamentais na cultura baniwa - a hierarquia de gerações - cuja ordem ancestral está ameaçada pelo próprio avanço da organização política do grupo, feita através de seus jovens. O aprimoramento do movimento indígena dos Baniwa contém, em seu próprio cerne, a possibilidade de contestação da hierarquia de geração e a alteração da posição relativa de prestígio e poder dos sujeitos engajados na mediação interétnica, em geral pessoas jovens; associe-se a isso um afrouxamento, amplamente reconhecido pelos membros do grupo, na disciplina pessoal entre os mais jovens e um bloqueio na transmissão dos antigos saberes para as futuras gerações e teremos um quadro de contornos sombrios.

Sè retomarmos a idéia de cultura de Sahlins (1990), caracterizada como uma rede de relações entre suas categorias constitutivas cuja estrutura pode ser transformada quando essas categorias mudam, podemos inferir que existe uma transformação em curso na sociedade baniwa na medida em que importantes categorias constitutivas estão em mudança acelerada, gerando efeitos que redimensionarão a própria estrutura social na qual elas se constituem, produzindo cenários que não temos hoje a possibilidade de prever. 
50 As relações com a Foirn assumem um caráter diferenciado, pois são dirigidas ao mundo indígena, mas transcorrem num espaço institucionalizado aos moldes do mundo do branco e compreendendo ainda as disputas e negociações com outros povos e Organizações Indígenas rionegrinos não-Baniwa.

51 Segundo a conceituação de Bourdieu (1989, 1996a, 1996b), o capital simbólico representa o reconhecimento e a legitimação num meio social, de uma acumulação de bens materiais e culturais por indivíduos ou grupos pertencentes a este conjunto social, capaz de lhes conferir condições sociais de êxito em intervenções concretas no cenário social; trata-se do poder socialmente reconhecido de impor uma certa visão de mundo, em concorrência com outras potencialmente válidas.

52 Na história das relações de contato do Alto Rio Negro, a escolarização aparece como um dos sinais distintivos do processo civilizatório desenvolvido pela Missão Salesiana. Atualmente, qualquer processo educativo desenvolvido recebe uma valorização imediata, independente de sua qualidade pedagógica e eficácia social. Nas representações e práticas sociais dos informantes da pesquisa, a escolaridade surge como um disputado objeto de desejo e de prestígio, que inflama as disputas intercomunitárias.

53 O conceito de Mercado Simbólico, caracterizado por Verón (1980) como um espaço social onde as posições políticas dos atores sociais se expressam através de discursos e práticas concorrentes e de alternância de posições de poder, se aplica a esta conjuntura baniwa, na qual coexistem distintas posiçōes políticas e econômicas, que surgem nos discursos desenvolvimentistas dos capitães, da politização da etnicidade nas Organizações Indígenas, do sanitarismo dos conselheiros e agentes de saúde, da religiosidade dos xamãs etc. Todos estes atores políticos disputam posições de poder e buscam a hegemonia na vida social.

54 Sigla de Cadastro Nacional de Pessoa Jurídica. O cadastramento é um procedimento formal necessário ao reconhecimento de uma empresa ou entidade sem fins lucrativos, para que a mesma possa atuar legalmente no Brasil. O processo legal de registro compreende uma série de passos burocráticos e o dispêndio de uma soma de recursos financeiros da instituição a ser cadastrada; ele se constitui numa medida imprescindível para a celebração de convênios para a captação de recursos e/ou comercialização de produtos pela Organização Indígena.

55 A ancoragem foi descrita por Moscovici (1989) como um processo do pensamento que consiste em classificar, nomear e inteligir, a partir de categorias, imagens e juízos já conhecidos, aquilo que é novo e desconhecido para o sujeito.

56 Pólo-base é um tipo de unidade de saúde que comporta ações mais complexas que aquelas disponíveis no posto indígena de saúde; assim, o pólo-base oferece atendimento médico, de enfermagem e alguns recursos laboratoriais.

57 O termo está sendo usado na formulação de Bourdieu (1989), com o sentido de acumulação de bens materiais por um grupo social, com geração subseqüente de prestígio e poder, e difere da idéia marxiana de capital como relação social de apropriação de mais-valia. 
58 O termo controle social é utilizado na saúde pública brasileira para designar o controle e o acompanhamento que a sociedade civil deve exercer sobre a aplicação das políticas públicas e dos recursos destinados à prestação de cuidados sanitários; via de regra, o controle social é exercido nos conselhos de saúde, onde são planejadas as ações de saúde destinadas a uma região geográfica determinada. 

A Politização da Etnicidade

$m$

峁

...está certo que todo mundo é igual, mas sempre tem que ter alguém pra ir primeiro, enfrentar as coisas...

Liderança baniwa 



\section{Mundialização, Globalização e Etnicidade}

O trabalho será aqui direcionado para os planos mais gerais do movimento indígena, priorizando, de um lado, a abordagem das interações entre os diversos grupos étnicos rionegrinos no espaço político da Foirn e, de outro, as mediações interétnicas travadas com agências brasileiras de contato e com grupos mundializados de apoio à causa indígena. O objetivo maior desta discussão é apreender como certas categorias oriundas do movimento indígena - externas ao mundo baniwa - circulam no espaço regional rionegrino, como são apropriadas e redimensionadas entre as lideranças de Organização de Base e chefias de aldeia baniwa e como influenciam em sua intervenção política no espaço multiétnico da Federação e nas instituições responsáveis pela implementação de políticas públicas.

Essa temática remete à discussão sobre manutenção e transformação da identidade étnica; porém, ela deve ser precedida por outro importante conceito, o de ocidentalização, habitualmente interpretada como processo civilizatório associado à idéia de modernização, um parâmetro dado pela cultura dominante às culturas subalternizadas (Latouche, 1996). Segundo Ianni (1995), a ocidentalização pressupõe a transformação de valores e padrões de comportamento, envolvendo a sacralização do mundo, o privilegiamento do indivíduo, o culto à propriedade privada, à racionalidade e ao urbanismo, características típicas dos padrões de vida e cultura das classes dominantes da Europa Ocidental e Estados Unidos da América. Esta concepção subentende a idéia de que progresso, evolução e aprimoramento da raça humana são sinônimos da adoção de padrões ocidentais de comportamento. Industrialização, modernização, ocidentalização e adoção de tecnologias avançadas são facetas da globalização que perpassam as diversas realidades planetárias.

Como os conceitos e valores subjacentes, a idéia de ocidentalização vem orientando as relações interétnicas desde os primórdios da colonização; antes da crise deste paradigma evolucionista, as sociedades indígenas pareciam fadadas ao desaparecimento, lhes restando como única alternativa de sobrevivência o amalgamamento aos padrões não-indígenas de vida e o abandono de suas formas próprias de conceber e intervir no mundo. 
A eclosão em diversos espaços políticos, sociais, econômicos e midiáticos do processo de globalização, ${ }^{59}$ tendo o ambientalismo como um de seus subprodutos, expressou de forma aguda a crise do paradigma da ocidentalização e deu visibilidade à heterogeneidade cultural das diversas sociedades do planeta, algo que nunca deixou de existir, mas que antes era negativamente valorada.

Ortiz (1994) demonstra que a globalização econômica e a adoção de um modelo básico de tecnologia geram um certo grau de homogeneização dos cenários mundiais que passam a se assemelhar entre si, mas isso não encontra equivalente no plano da cultura, pois, apesar dos prognósticos em contrário, o processo de globalização não aniquilou as manifestações culturais singulares em favor de uma única, tendo na verdade promovido uma revalorização das especificidades e heterogeneidades culturais. Para o autor, as estruturas econômicas globalizadas são simultaneamente homogeneizantes e heterogeneizantes, pois, se por um lado promovem uma padronização da produção capaz de anular as diferenças, por outro, não abolem as disparidades locais nem a formação de grupos segmentados que passam a compor a sociedade civil mundial e que incorporam as totalizações de formas díspares e contraditórias, recriando o global por meio de especificidades que não são incompatíveis com a globalidade, mas a ela se subsumem (Ortiz, s.d.).

Ele lança uma importante distinção entre os conceitos de pattern e standard; o primeiro termo traduz a idéia de "normas estruturantes do comportamento social", ao passo que o segundo se refere particularmente ao processo de produção de objetos. Na globalização, existe uma uniformidade da base tecnológica - que homogeneiza o processo de produção de objetos - mas não uma padronização similar dos comportamentos sociais; estes permanecem plurais coexistindo com os elementos homogêneos do capitalismo global (Ortiz, 1994).

A existência de modelos diferenciados de pattern não anula a padronização e subalternização forçada ao padrão standard imposto pela tecnologia; ambos são situações complementares, num mundo em que já não existem grupos sociais desligados do fluxo principal da cultura mundializada. O caráter e intensidade dessas inter-relações são bastante variáveis, mas nenhum grupo social pode hoje se situar efetivamente como uma exterioridade em relação à cultura mundial (Ortiz, 1992). Tais condições interativas levam à necessidade de problematizar a idéia convencional de imposição de valores e comportamentos de uma cultura à outra, num contexto mutante no qual o que era externo, pertencente a um padrão mundial, pode tornarse nativo, legitimando-se por meio da inserção em práticas locais de caráter amplamente polifônico. Instituições e comportamentos ditos tradicionais convivem com formações socioculturais mundializadas, que por sua vez podem assumir configurações inesperadas ao serem reapropriadas pelos grupos subalternizados (Ortiz, 1994). Nesse contexto, a adoção de padrões globalizados de comportamento, como o uso de bens tecnológicos, em vez de se constituir apenas em fator de 
dependência e de destruição da organização da sociedade, pode passar a figurar como parte das estratégias de luta pela autonomia política e econômica de povos indígenas (Turner, 1993b).

Uma das possibilidades abertas por um sistema permanente e mundializado de comunicação é o estabelecimento de grupos sociais desterritorializados, distintos daqueles que constituíam anteriormente as sociedades nacionais; os extratos sociais estabelecidos na dinâmica própria do Estado-nação permanecem existindo, mas podem se rearranjar na forma de grupos de interesse, articulados a partir de "redes de cultura" interativas e mundiais (Ortiz, s.d.; Araújo, 1998). Essas redes interligam permanentemente as mais distantes regiões do globo, viabilizando o funcionamento de um sistema econômico e financeiro mundial, reduzindo a importância das fronteiras territoriais e possibilitando a formação de alianças entre grupos aparentemente díspares. Neste tipo de rede, situamos o entrelaçamento que se formou entre o movimento indígena e o ambientalismo, colocando as Organizações Indígenas num eixo de articulação entre universalismos e localismos e superando um cenário anterior em que as culturas indígenas se referiam essencialmente às políticas indigenistas produzidas pelo Estado nacional. A liderança indígena - ligada em seu cotidiano imediato ao poder local que a constitui e legitima sua participação - é guindada ao papel de interlocutor de uma comunidade discursiva mundial.

A globalização da Amazônia não é um evento ínédito, tendo se expressado de diversas maneiras desde o início da história da colonização. $\mathrm{O}$ que o momento atual apresenta de novo é a possibilidade de que grupos subalternizados, como os indígenas, possam angariar apoio político participando de redes desterritorializadas, detentoras de poderes e influência capazes de ampliar a ressonância de suas lutas por direitos étnicos e sociais, de auxiliá-los na obtenção de posições menos assimétricas que aquelas anteriormente disponibilizadas e a perceber e valorizar uma diferença étnica até então naturalizada, oferecendo um contraste pelo qual eles reelaboram sua etnicidade. A agilização do fluxo de circulação da tecnologia permite tanto uma maior penetração das ideologias e práticas globais na vida aldeã, quanto o fluxo inverso, possibilitando aos índios a veiculação de suas propostas e reivindicações em redes mundiais como a $W E B$.

A valorização de culturas locais também já ocorreu em outros momentos históricos, mas nessas ocasiões não existiam os meios de comunicação que hoje viabilizam a circulação das idéias com uma intensidade capaz de fazer diferença na vida cotidiana das pessoas. Igualmente eles tornam possível a atores políticos estritamente locais constituir ou participar de redes globais de interesses estabelecendo alianças que permanecem assimétricas - pois os centros de decisão estão fora de seu alcance e as oportunidades de obter visibilidade e credibilidade não são igualmente acessíveis a todos -, mas que ainda assim têm propiciado um 
maior grau de governabilidade dos índios sobre os seus destinos, que o obtido nas fases anteriores do processo colonizatório.

No mundo indígena, este fenômeno gera saberes e vivências que modificam e redimensionam suas práticas sociais e influem no modo de viver; suas lutas pelos direitos étnicos concretizam um tipo de "educação mundializada," que se expressa na partilha de bens simbólicos de uma cultura mundial que já pode até ser pensada como mecanismo interno de uma mega-sociedade em expansão (Ortiz, 1994:97). Também existe uma partilha desigual de bens econômicos que, mesmo desfavorável aos índios, lhes propicia a aquisição de artefatos industrializados. $\mathrm{O}$ uso desses produtos não é sinônimo de adoção automática dos princípios culturais do ocidente, pois, se os indígenas usam tênis, relógio, computador ou GPS, isso não significa que houve uma assimilação de suas expressões culturais à cultura de onde provêm estes bens econômicos, pois cultura e economia não são dimensões equivalentes da realidade e a cultura não deve ser reduzida a seus produtos (Ortiz, 1994).

As Organizações Indígenas podem exprimir uma face mundializada ${ }^{60}$ quando se ordenam na forma de rede descentrada, pertencente a todos os lugares, representando todos os índios, sem limites geográficos e/ou fronteiriços bem definidos, construindo um grupo de interesse definido através da diferença étnica. Tais características surgem em entidades de abrangência muito ampliada como a Coordinación de las Organizaciónes Indígenas de la Cuenca Amazônica (Coica), a Coordenação de Articulação dos Povos Indígenas do Brasil (Capoib) e, dentro de certa medida, também na Coiab, que evidenciam este caráter desterritorializado, contrário à lógica das sociedades indígenas, cujas relações de poder se orientam por territorialidades restritas e bem definidas. Para os habitantes comuns das aldeias, grandes estruturas como a Coiab e a Coica são meras abstrações que não têm expressão concreta no seu cotidiano.

A dinâmica do movimento indígena constrange as direções das grandes Organizações a priorizar atividades que, mesmo sendo de interesse dos grupos aldeados, costumam ser desenvolvidas fora do espaço tribal, comprometendo a visibilidade de seu trabalho nas aldeias e instaurando uma crise permanente de legitimidade de lideranças que priorizam ações políticas em espaços globais, mas representam culturas que valorizam o poder local.

As lideranças das grandes Organizações são colocadas num duplo e contraditório papel, que elas devem harmonizar em si próprias: diluir sua identidade numa condição genérica de índio em luta, demandando direitos de cidadania e, ao mesmo tempo, reafirmando a diferença étnica ante as sociedades nacional e mundial. Carregam, de modo imperceptível para os não-índios, as marcas indeléveis de sua identidade tribal, da pertinência a um grupo étnico específico, de uma língua materna diferenciada da língua nacional, enfim, de formas diferenciadas de 
socialização, que, embora perpassadas pela cultura mundial, não se reduzem a ela. Nestes espaços políticos desterritorializados, a manipulação da identidade étnica assume uma auto-objetivação na adoção da identidade de índio genérico que favorece a superação conjuntural de rivalidades e disputas clânicas, propicia a reelaboração cosmológica do contato e permite estabelecer uma solução de compromisso entre o universal e o particular, instalando um campo de negociação interétnica (Bartolomé, 1979, 1995).

Uma das conseqüências do descompasso entre os planos local e geral do movimento indígena é a migração para as grandes entidades de lideranças que se inviabilizaram em suas áreas de origem, gerando uma espécie de exílio para cima por meio do qual a liderança desgastada tenta reconstruir uma nova forma de intervenção mais afastada do espaço local, conforme evidencia o depoimento abaixo:

É, isso acontece mesmo; não é todo mundo que vem para uma organização grande que está queimado na base, mas acontece sim. É mais comum quando as pessoas da base não entendem o papel das entidades grandes. Eu sou contra isso porque é um prejuízo para a comunidade local e para a organização maior. Para mim, o melhor seria não fazer isso e sim tentar recuperar essa liderança no seu local de origem; a base é que tem o poder de recuperação do trabalho dessas pessoas; não devia deixar ela vir ou mandar ela para se livrar de um problema porque, quanto mais longe, maior é a chance dela se complicar aqui fora; aqui não tem quem faça um controle político do trabalho dessa liderança. (R .T., Baniwa, ex-dirigente da Coiab e da Foirn)

As lutas étnicas capitaneadas pelo movimento indígena são travadas num cenário em que se entrecruzam distintos modos de conceber a vida; sua intervenção pressupõe a existência de discursos concorrentes, enunciados por portadores de 'pontos de vista'61 que variam segundo suas posições na cena social, na qual representam interesses diversos, cuja coexistência as lideranças devem gerenciar. Assim, é possível observar, entre muitos representantes das gerações mais velhas e dos primeiros dirigentes do movimento indígena, aqueles que buscam um padrão ocidentalizante de comportamento e a negação de sua cultura de origem, mas também aqueles que são influenciados pelas idéias ambientalistas e de revalorização da etnicidade, que se esforçam por fazer valer suas idéias e suas interpretações sobre presente e futuro do mundo indígena. Entre ambos os grupos existe uma massa de pessoas, cujas posições podem oscilar conforme a eficácia social de cada discurso.

Antes da interveniência do movimento etnopolítico rionegrino, o futuro parecia passar pela aceitação de uma definição, não apenas exógena da identidade, mas também centrada na negação dos elementos da cultura tribal na adoção do estilo de vida ocidentalizado. 
Essa coisa toda começa na escola do missionário; eles queriam apoiar a educação para nós deixarmos de ser índios. Os caras diziam: vocês vão estudar, vão ter escola, vão ser educados, vão se vestir, vão ficar bonitos... as pessoas gostavam, eu gostava e ficava pensando: eu quero ser aviador, quero ser piloto da FAB ou então ser professor, não quero ser índio, que é uma coisa atrasada. Isso era uma coisa muito ruim, era pior do que pegar uma arma e matar o sujeito, porque o que eles faziam era envenenar a alma da pessoa, fazendo a gente odiar o que a gente era... Só depois que eu comecei a participar do Cimi, a ir naquelas reunióes nacionais, eu comecei a ver a verdade. Naquele ano de 88, nós estávamos querendo colocar uma lei pra garantir os direitos dos índios. Eu via os Kayapó lutando, aí eu comecei a me interessar por esse lado. Puxa vida! Meus parentes não são diferentes desses Kayapó, eles também precisam de apoio; foi aí que eu comecei a me interessar desse trabalho, a lutar para colocar os direitos dos povos indígenas na Constituição, a defender nossas terras e o nosso ambiente. (L. A., Dessana, ex-dirigente da Foirn e parlamentar indígena)

A identidade assume aqui uma configuração dinâmica que se constrói e se transforma nas fronteiras étnicas, situação em que as lideranças indígenas buscam obter visibilidade social e negociar posições favoráveis na arena política do espaço interétnico. Ela se consubstancializa apenas na presença/existência da alteridade (Barth, 1988, 1998); é o contraste oferecido pela diferença que permite à liderança Dessana, antes desatenta às manifestações de sua própria cultura, empreender primeiro um processo de negação identitária, expresso no desejo de ser piloto, professor ou de adotar qualquer forma de não ser indígena para depois, ante um alteríndio de sua admiração, reformular sua auto-imagem, valorizando a recém-adquirida consciência étnica.

Práticas discursivas como estas remetem a uma identidade-processo, em permanente ressignificação, rejeitam o fixismo de um modelo prescritivo; e mostram que esta deve ser permanentemente reconstruída segundo as necessidades e prioridades geradas no contato intersocietário estabelecido não apenas com o mundo dos brancos, mas também com outros grupos indígenas. Em regiões como o Alto Rio Negro, a etnicidade comporta elementos de um prolongado processo colonizatório, com a incorporação de diversos saberes e ideologias alheios ao núcleo central dessas culturas. Embora a ordenação mítica se mantenha como discurso fundador e agregador das formas de atribuir sentido à realidade, as representações sociais elaboradas pelos indígenas evidenciam uma permeabilidade a elementos ressignificados da cultura do colonizador que foram incorporados ao ethos de cada grupo, permitindo releituras críticas das normas culturais e a geração de estratégias cognitivas que favoreçam as interações com a alteridade.

Essa é uma dinâmica que supera os habituais questionamentos sobre a autenticidade/inautenticidade das iniciativas de reconstrução cultural promovidas pelo movimento etnopolítico, os quais traem uma concepção de estática da 
etnicidade, negando aos agentes políticos indígenas a possibilidade de, ante as transformações e injunções forjadas pela alteridade, promover reinterpretações, recortes e seleções de elementos da cultura e de decidir ativamente sobre as formas de seu redimensionamento e sobre quais deles devem ser repassados para as futuras gerações.

As organizações indígenas que se constituíram ao longo da década de 90 se caracterizam, por um lado, como uma forma de luta para obtenção de melhoria das condições de vida, mas, por outro, sua dinâmica interna estabelece importantes transformações na concepção de etnicidade de suas lideranças. Essas aprendem a partilhar símbolos da modernidade, a transitar pelas linhas de força da globalização e a mobilizar valores e padrões culturais produzidos fora das fronteiras da terra indígena. Tal movimentação 'para fora' redimensiona o modo como essas lideranças lidam com as manifestações de sua cultura de origem. A consciência da 'indianidade' adquirida no mundo não-indígena torna as lideranças mais alertas e sensíveis para a necessidade de preservar rituais, saberes tradicionais e o meio ambiente onde vivem, não apenas para negociar com poderes externos ao mundo indígena, mas também por que percebem que mudanças nas antigas pautas de comportamento se fazem necessárias, a fim de dar conta dos novos desafios que se constituem no contato com a modernidade.

Nas grandes reuniões e assembléias realizadas em contextos supralocais, observa-se um manejo identitário progressivamente ampliado de acordo com a abrangência do fórum político do qual a liderança participa. O uso de múltiplas identidades e da língua portuguesa como língua franca nesses eventos configura a presença de estratégias neutralizadoras, negadoras das divisões internas em busca de consensos práticos, unificadores das tensões entre os grupos. Em busca de alianças capazes de ampliar o poder de negociação e deliberação em espaços políticos amplos, as lideranças efetuam uma relativização temporária da identidade tradicional, mesmo que, na vida cotidiana e na política das aldeias, a identidade operativa permaneça sendo aquela ligada ao sib e à fratria.

Tais artifícios não são utilizados apenas no espaço de interações dos grupos étnicos entre si, mas são também aplicados nas negociações com instituições nãoindígenas, nás quais as lideranças estabelecem sentidos particulares da unidade e identidade indígena, passíveis de serem apreendidas pelos não-índios e gerar resultados positivos na negociação. O 'ser indígena' configura uma identidade que longe de ser meramente inventada ou contrastiva com a população regional, se expressa como um processo multifacetado de circulação de significados que, sem negar o que é estrutural, assume um caráter historicamente dinâmico em sua configuração cada vez mais perpassada pela realidade mundial. 


\section{Movimento indígena como movimento social}

Antes de prosseguirmos, faz-se necessário problematizar a idéia de 'movimento indígena', tomado até aqui como um dado, sem uma adequada discussão deste conceito.

Em uma extensa revisão sobre a teoria dos movimentos sociais, Gohn (1997) discorre sobre as diversas vertentes do tema, partindo das clássicas abordagens do funcionalismo e estrutural-funcionalismo, passando pelas contribuições sobre a Escola de Chicago e do Marxismo até chegar à teoria dos Novos Movimentos Sociais.

Para ela, movimentos sociais são "expressões de poder da sociedade civil e sua existência, independentemente do tipo de suas demandas, se desenvolve num contexto de correlação de força social. Eles são, portanto, fundamentalmente, processos políticos-sociais" (Gohn, 1997:251).

A rigor, o movimento indígena não se enquadra plenamente em nenhum dos enfoques habitualmente utilizados para a análise dos movimentos sociais, particularmente quando nos debruçamos sobre as características e contradições internas das culturas que lhes oferecem a base organizativa. Entretanto, estas produções teóricas se tornam úteis para o entendimento de suas formas de institucionalização e das interações travadas com nichos de poder do mundo nãoindígena. Mesmo reconhecendo os limites de um potencial enquadramento do movimento indígena nas correntes teóricas que os descrevem, encontramos mais afinidades entre a realidade rionegrina e a abordagem dos Novos Movimentos Sociais que priorizou "a criação de esquemas interpretativos que enfatizavam a cultura, a ideologia, as lutas sociais cotidianas, a solidariedade entre pessoas de um grupo ou movimento social e o processo de identidade criado" (Gohn, 1997:121).

Os autores dessa corrente rejeitam as abordagens centradas apenas em questões macroestruturais genéricas, como o economicismo, incapazes de dar conta da influência dos aspectos culturais, das interações travadas entre indivíduos e grupos e de como os constrangimentos estruturais influenciam no comportamento dos atores sociais que intervêm nos processos políticos instaurados pelo movimento social.

Estudiosos dos Novos Movimentos Sociais, como Alberto Melucci (1994) e Cohen (1985), os tratam como processos sociais em construção, fugindo das abordagens sistêmicas estabilizadas e procurando abarcar as práticas cotidianas dos sujeitos, ligadas às relações micropolíticas, inclusive as não-institucionalizadas, como o espaço doméstico, as interações afetivas, de gênero e de comunicação. Sua abordagem prioriza questões relativas aos sistemas de valores de grupos sociais, não redutíveis à mera análise macroeconômica. Essa perspectiva não nega o exercício do poder nas macroesferas do Estado e também favorece o entendimento de como os movimentos sociais podem passar historicamente de uma atuação informal para instituições políticas estruturadas e em interação com o sistema hegemônico de 
poder. É uma perspectiva em rede, que procura articular os aspectos macro e microssociais e culturais e que se adequa à abordagem que desejamos enfatizar na análise do movimento social rionegrino.

Cohen \& Arato (1992:138) denominam esses processos microssociais de "mundo da vida", um subsistema da sociedade civil voltado para "a emergência de instituições especializadas na reprodução de tradições, solidariedades e identidades". Embora o conceito de mundo da vida tenha sido criado para contextos urbano-industrializados, ele se mostra passível de aplicação na análise das relações do movimento indígena com ambientalismo e com aliados e assessores oriundos da sociedade mundializada.

Melucci (1980) também distingue 'movimentos políticos' - ações coletivas que buscam ampliar a participação política e a posição dos membros do grupo nos processos de tomada de decisão - de 'movimentos organizacionais' que seriam um tipo de comportamento coletivo fundado em uma dada organização, cujas atividades podem ser dirigidas contra o poder de governo e o sistema de normas e de papéis sociais preexistentes, tendendo igualmente para a transgressão dos limites que lhes são impostos externamente. Para o autor ambos se constituem como estratégias distintas dentro de um mesmo processo de mediação que une a organização social ao sistema político. Ele relembra, porém, que uma das principais características dos novos movimentos sociais é que eles não almejam a tomada do poder político, direcionando mais os seus esforços para a satisfação de necessidades, que é o que ocorre no Alto Rio Negro.

Segundo a forma de organização, os novos movimentos sociais costumam ser descentralizados, portando estruturas colegiadas que favorecem a participação, deixando pouco espaço para líderes que tentam exercer poder sobre seus liderados a partir de sua oratória e carisma. Tal característica é de especial interesse para a análise do movimento indígena, que rejeita as estruturas piramidais do sindicalismo e prioriza as decisões colegiadas em assembléias e reuniões de conselhos deliberativos. Além disso, o movimento indígena no Brasil atravessa um momento de mudanças, no qual as lideranças carismáticas que centravam suas ações nas denúncias e na militância em grandes entidades nacionais com escassa penetração nas aldeias vêm cedendo lugar a um conjunto de microentidades de atuação local ou microrregional com um perfil mais voltado para o gerenciamento de projetos e ações de auto-sustentação. Esta mudança, para Albert (2000:198), vem produzindo uma "rotinização do discurso étnico", na qual "a afirmação identitária se tornou pano de fundo para uma busca de acesso ao mercado e, sobretudo, ao 'mercado de projetos' internacional e nacional, aberto pelas novas políticas descentralizadas de desenvolvimento (local/sustentável)".

Segundo esse autor, a intrusão das vidas e territórios indígenas pelas frentes colonizatórias na Amazônia vem produzindo uma reconstrução 
sociossimbólica dessas culturas, dependente de processos legitimadores externos, configurados e impostos pelo Estado e pelas entidades não-governamentais de apoio e solidariedade aos povos indígenas. As estratégias identitárias e as lutas territoriais travadas pelas entidades etnopolíticas são indissociáveis da conjuntura nacional e internacional que hoje envolve a Amazônia e que tem tornado possível aos indígenas se apropriarem do sistema de leis e de valores simbólicos, gerados pelos grupos sociais (não-indígenas) que dominam politicamente o espaço de relações interétnicas (Albert, 1995:182). A apropriação indígena de saberes e poderes institucionais oriundos do mundo não-indígena e utilizados para reforçar as lutas étnicas tem gerado, entre outras conseqüências, a institucionalização de suas organizações.

Albert (1997a) demonstra que categorias reivindicatórias, como 'comunidades' e 'terras indígenas', que vêm sendo manejadas pelo movimento indígena em suas estratégias de mobilização, assim como seus principais "registros de legitimação", representados pela diferenciação étnica, os saberes sobre a ecologia e a ética da diferença, são exodefinições construídas pelas agências de contato e entidades de apoio. De modo análogo, uma identidade de "índio genérico" foi produzida pela atuação do indigenismo oficial e vem sendo utilizada pelo movimento indígena, ainda que simbolicamente reconstruída, em suas negociações etnopolíticas. Porém, o autor ressalva que o enfoque sobre o papel central representado pelo Estado e entidades indigenistas não-governamentais não anula a riqueza da etnicidade construída na experiência reivindicatória e nas inter-relações com entidades de solidariedade internacional por meio das quais o movimento indígena tem adquirido as "ferramentas discursivas e as relações sociais necessárias" para o enfrentamento ou negociação de proposições com o indigenismo oficial (Albert, 1997a:185-186).

Gohn (1997) também assinala a tendência de transformação do movimento, ou partes dele, em organizações, mas sem descartar a possibilidade de que o inverso se dê, ou seja, de que instituições preexistentes possam dar origem a movimentos sociais. No caso indígena, os relatos históricos feitos por Ramos (1997), Ortolan Matos (1997) e Albert (1997a, 1997b) demonstram que a intervenção de entidades preexistentes, como a Igreja e grupos de solidariedade nacional e internacional, viabilizou a constituição do movimento indígena no Brasil, que, por sua vez, vem percorrendo a trilha de uma progressiva institucionalização de suas organizações, com aquisição de sedes próprias, eleições regulares de diretorias, registro de estatutos em cartório, abertura de contas bancárias e organizações de setores administrativofinanceiros para o gerenciamento de recursos e projetos, aprofundando, por esta via, sua face de movimento organizacional (Ricardo, 1995).

Essa trajetória não é uma peculiaridade do movimento indígena, sendo comum a grupos políticos que buscam reconhecimento pelas instâncias formais de 
poder, o que costuma exigir uma estrutura organizacional com a presença de representantes formalmente eleitos e a constituição de instâncias burocráticas que intermedeiam as interações correntes com outras instituições, particularmente com os representantes do Estado (Doimo, Doxsey \& Beling, 1986). Os líderes das organizações indígenas também precisam fazer escolhas e tomar decisões racionais em busca de financiadores, adeptos, apoios políticos e consumidores de produtos étnicos. Desenvolvem ações de gerenciamento, competem por fontes de financiamento para o desenvolvimento de suas atividades e participam de um mercado de bens simbólicos, em que efetuam cálculos de custos e benefícios para subsidiar suas ações, o que permite caracterizá-los, neste aspecto, como um grupo de interesses.

No Alto Rio Negro, o movimento indígena se insere no tecido social como entidade mobilizadora e no plano político mais amplo, no qual se tomam decisões sobre a distribuição dos recursos produzidos no mundo não-indígena, buscando intervir nele através de argumentos fundamentados na diferenciação étnica. Seus líderes efetuam uma mediação entre identidades étnicas e identidades políticas, instaurando definições identitárias estruturadas em torno de um 'nós', índios, em oposição a 'eles', não-índios, por meio das quais procuram legitimar-se e conquistar posições no cenário político.

Porém, mesmo que as idéias políticas das lideranças indígenas sejam profundamente marcadas pela oposição branco-índio, pode-se observar uma complexificação na teia de relações de poder; nela, os atores sociais mudam suas posições no campo político intersocietário, de acordo com os contextos que precisam enfrentar, situando-se como indígenas ora em consonância, ora em oposição ao mundo dos brancos ou com as produções de sua cultura de origem. Em outros momentos, são os brancos que desempenham tais papéis, instaurando uma dinâmica que permite a construção de alianças variadas e transitórias em que se intercambiam interesses e prioridades dos blocos de poder que cruzam a questão indígena.

Aqui se configura um cenário em que a oposição de 'nós índios' e 'eles, os brancos', é estritamente conjuntural, habitualmente se expressando em espaços políticos públicos do campo interétnico, particularmente na mídia e nos documentos oficiais do movimento indígena. Nas relações concretas do cotidiano, as oposições entre brancos e índios podem se borrar e se reconstituir como alianças entre grupos de lideranças indígenas e de representantes institucionais não-indígenas, variando em virtude do tipo de objetivo perseguido. No entanto, as relações entre os próprios índios não têm caráter homogêneo; são igualmente interações conflituosas que tanto recobrem divergências tribais irredutíveis, quanto alianças e oposições transitórias formadas nas disputas eleitorais e de recursos materiais e simbólicos. Em consonância com o estilo rionegrino de exercício de poder político, sua expressão pública costuma ser sutil, sendo quase imperceptível ao observador desavisado. 
Das análises de Gohn (1997) sobre as formas de intervenção dos movimentos sociais, destacamos algumas que sintetizam as principais características de ação etnopolítica no Alto Rio Negro:

- a presença de uma consciência grupal, um sentimento de pertença a um grupo articulado por compromissos coletivos que se desenvolvem como um espirit de corps, criando uma idéia de coletivo;

- a necessidade de utopias, de ideais de transformação da realidade que vão além do que é factível de se obter no momento atual;

- a tendência à institucionalização, com o objetivo de ganhar reconhecimento na sociedade mais ampla em referência à qual eles se constituem; tais práticas, inicialmente informais, costumam trilhar um grau progressivo de formalização;

- a existência de um ativo processo de produção de representações sociais e identitárias, que se desenvolve mediante relações de comunicação e de cooperação em atividades cotidianas como reuniões, assembléias, viagens, elaboração de documentos, uso do espaço midiático, conversas em bares, documentos, uso da Internet, elaboração de jornais e boletins informativos sobre as atividades do movimento etc.;

- a partilha de identidades e crenças que une e facilita a mobilização dos membros do movimento social; tais identidades são reconstruídas em processo e fazem parte de um conjunto de negociações políticas travadas entre os integrantes do grupo e seus interlocutores, na busca de obter respostas e soluções para os problemas detectados;

- a manipulação de símbolos e ideologias construídos fora do movimento e, algumas vezes, anteriores a ele, mas que são recriados e ressignificados no decorrer de suas atividades, sendo manejados pelas lideranças para reforço do processo político em curso, e incorporadas como parte de seu projeto e trajetória política. Tais disputas simbólicas envolvem a busca pelo controle dos significados e interpretações hegemônicas dos fatos e eventos políticos de interesse do movimento;

- atividades que envolvem conflitos de interesse e relações de poder entre etnias distintas, em busca de acesso a bens e políticas públicas capazes de melhorar sua qualidade de vida;

- a dependência em que o seu sucesso, em grande medida, se encontra do reconhecimento político pelos grupos com os quais interagem e do grau de obtenção dos benefícios pelos quais luta; entretanto suas atividades não almejam apenas recursos, mas também reconhecimento e a legitimidade;

- a produção de elites políticas que atuam inicialmente nas próprias instâncias do movimento, mas que são progressivamente incorporadas em outras instâncias de poder.

Essas características dos movimentos sociais, selecionadas em razão de reconhecermos sua expressão na realidade rionegrina, serão utilizadas ao longo do texto, para pontuar formas de atuação do movimento indígena na região. 
Para Sztompka (1993), os movimentos sociais podem ainda ser agrupados segundo as motivações subjacentes à sua ação, o tipo e abrangência da mudança almejada pelas atividades que desenvolvem. Nessa perspectiva, pode-se dizer que o movimento dos indígenas rionegrinos pode ser caracterizado como um conjunto de iniciativas políticas que busca um reconhecimento de seu modo de vida e de sua diferença cultural, o que coexiste com uma lógica instrumental que visa à conquista de espaços de poder político em frações do Estado, tal como ocorre na terceirização em saúde e na busca de cargos de representação parlamentar.

Embora os esforços de lideranças expressivas do movimento indígena rionegrino tenham se voltado para a busca de mudanças sociopolíticas dos valores e crenças ligados à imagem e lugar do índio no mundo não-indígena, é possível observar uma lacuna entre tais objetivos e as práticas de suas Organizações, que demonstram, no momento atual, um baixo nível de mobilização para obtenção de mudanças no sistema de leis e regulamentos indigenistas, sanitários e outras disposições legais que discriminem ou inflijam penas aos povos indígenas. Habitualmente, o que se observa é a busca de amparo na legislação que regulamenta a questão indígena e da aplicação prática dos direitos nela garantidos, sem um questionamento mais profundo da estrutura legal vigente no País. É dentro deste enquadre legalista que se situam as facetas reivindicatórias, interessadas em ampliar o poder de decisão e acesso aos canais de definição de políticas públicas e intervir nos processos de aplicação/destinação de recursos para sua implementação.

Com base nas características que acabamos de discutir, passaremos a analisar o movimento indígena rionegrino, enfatizando posteriormente sua expressão na área baniwa.

\section{Situação atual do movimento indígena rionegrino}

O início do movimento indígena no Brasil, no início dos anos 80 , foi marcado pelas reuniões e assembléias nas quais lideranças de diversas regiões do País trocavam experiências e denunciavam agressões e a exploração a que eram submetidos na violência do contato interétnico. Segundo Matos (1997), esse período, orientado pela idéia de um pan-indigenismo, se caracterizou pela formulação de denúncias sobre as más condições de vida, de surtos epidêmicos, mortes indígenas e pelas bandeiras de luta pela demarcação da terra.

A Foirn foi fundada em 1987, no tumultuado contexto gerado pela intrusão das mineradoras e da agressiva política desenvolvimentista do Calha Norte (Oliveira Filho, 1990). Logo a entidade entrou no compasso das pautas do pan-indigenismo praticado em nível nacional, do qual algumas de suas lideranças já tinham experimentado a militância. Segundo a rememoração de lideranças da época, suas principais atividades eram a articulação para discutir a demarcação, a esta altura 
já encaminhada pelo Projeto Calha Norte, e propostas para a valorização da cultura indígena, o que nem sempre era bem recebido por chefias de aldeia acomodadas à negação dos sinais diacríticos de sua etnicidade.

Apesar da importância atribuída ao discurso etnopolítico, a necessidade de oferecer respostas econômicas já estava presente desde o primeiro momento da entidade:

Quando a Foirn foi criada já era devido a problemas econômicos. No fundo, a divisão que o Calha Norte causou entre as comunidades era um problema econômico; as pessoas tinham necessidades e o projeto prometia uma saída para esses problema; por isso muitas comunidades e lideranças apoiaram os militares. É claro que a luta pelos direitos estava no estatuto da Foirn, mas o que fez as pessoas se movimentarem em torno da Federação era o desejo de achar saída para a auto-sustentação; isso já estava lá desde o começo (R. T., Baniwa, ex-dirigente da Foirn)

Cientes de que o discurso etnopolítico sozinho era incapaz de prover a adesão à utopia veiculada pelo movimento, por parte de liderados que demandavam transformações concretas na sua realidade cotidiana, as lideranças buscaram formas de atuação centradas no desenvolvimento de projetos sociais e econômicos. Essas pressões oriundas das bases exerceram uma influência decisiva na superação precoce do 'denuncismo' que se manteve por muito mais tempo em outras entidades no resto do País. Tal possibilidade se concretizou com a obtenção de financiamentos vindos dos países europeus, direcionados ao desenvolvimento de projetos de autosustentação. Os acordos firmados demandavam o estabelecimento de uma assessoria técnica para a entidade, papel assumido pelo Instituto Sócio-Ambiental, que passou a desenvolver uma parceria regular com a Foirn.

A opção feita pela diretoria da Foirn não só se concatenou com as demandas de parcerias e financiadores, mas também representou um encontro com as expectativas geradas pela concepção de chefia política vigente nas aldeias, nas quais se exigia que também os mediadores das relações interétnicas fossem capazes de captar bens e serviços para redistribuição comunal, sob pena de esvaziamento da retórica política do movimento indígena.

O Estado brasileiro tem intervido como um fator essencial na definição de rumos e estratégias da organização política do movimento indígena, seja para se opor, como se deu nos seus primórdios, seja para propor parcerias na execução de políticas públicas, tal como ocorreu com a demarcação das terras indígenas do Alto Rio Negro e como vem se dando na implantação do Distrito Sanitário Especial Indígena. No momento atual, observa-se em entidades na Foirn e nas Organizações de Base mais estruturadas uma tendência de aproximação, expressa numa constelação de reivindicações estruturadas não apenas em torno da busca de bens e serviços do poder de Estado - sendo essa uma demanda que nunca cessa totalmente -, 
mas também do direito de participar politicamente das decisões que afetam suas vidas e culturas, na rejeição à condição de tutelado e no propósito de demonstrar capacidade de gestão e execução de políticas públicas para elas direcionadas.

A análise das pautas discutidas nas reuniões ${ }^{62}$ do Conselho Administrativo da Foirn (CAF), de 1999 a 2001, mostra alguns temas recorrentes, tais como a avaliação do trabalho desenvolvido e o planejamento de ações para o período seguinte, discussão de relatórios de atividades de Organizações de Base e prestação de contas. A partir de 1998, o convênio de saúde com a Funasa apareceu nas pautas de todos os eventos; outros podem surgir conjunturalmente, dependendo das demandas e fatos políticos que se sucedam no cenário local e extralocal. As pautas costumam equilibrar questões de relevância política mais ampla com questões administrativas ou gerenciais de interesse local.

Também podem ser citados, para o período enfocado, assuntos como a implantação da rede de radiofonias, plano de fiscalização das áreas demarcadas, Marcha dos 500 anos, Fórum de Direitos Indígenas e discussão sobre potenciais candidatos indígenas para as eleições municipais, proposta de criação de Território do Rio Negro pelo governo do Amazonas, construção de hidrelétrica pelos militares na região do Médio Rio Negro, Lei de Patentes e de Propriedade Intelectual e presença de pesquisadores em áreas indígenas.

Mesmo não formando uma listagem exaustiva das discussões travadas nas reuniões do CAF, observa-se que a maior parte dos temas citados se origina em contextos externos ao mundo indígena, reforçando a idéia de Albert (1997) de que o Estado e as ONGs permanecem configurando a movimentação política indígena. Pelo menos em entidades grandes como a Foirn discussões são, em boa parte, respostas a necessidades e problemas gerados por atores sociais não indígenas. As discussões, internamente geradas, que costumam despertar maior interesse dos delegados presentes, giram em torno da distribuição de bens e serviços viabilizados pela Federação.

A trajetória seguida pela Foirn mostra uma busca de legitimação através da participação nos espaços de poder e de decisão na condução de políticas públicas setoriais de interesse imediato, mas não consegue encobrir a ausência de propostas sistemáticas de redimensionamento dessas mesmas políticas públicas; durante o período de observação, a única iniciativa deste tipo foi o Plano de Proteção e Fiscalização das Terras Demarcadas, que foi apresentado à Funai, comportando uma proposta de reformulação das finalidades e formas de atuar do órgão no Alto Rio Negro. Essa lacuna é percebida por algumas lideranças que reclamam da ausência de uma agenda propositiva nas negociações com o Estado, situações em que as entidades têm se limitado a reagir às iniciativas governamentais, não raro se adequando a moldes preestabelecidos por aquele. 
Uma vez superada a grande e unificadora bandeira da demarcação das terras, observa-se uma tendência a priorizar outros espaços de negociação, particularmente no campo de políticas sociais como a saúde, a educação e a produção. Tourraine (1989) reconhece esta opção como uma das facetas típicas dos novos movimentos sociais da América Latina, por ele caracterizados como movimentos organizacionais, que têm direcionado esforços para o controle dos propósitos da produção cultural, tais como a finalidade da escola, dos cuidados de saúde e dos veículos de comunicação de massa.

Esses campos de atuação das Organizações vêm crescendo em importância e freqüência nas pautas e atividades do movimento indígena, que tem pleiteado não apenas a ampliação do número de escolas e de serviços de saúde nas áreas indígenas, mas também buscado um redimensionamento nas características e finalidades de sua atuação, expressos nas reivindicações por uma educação bilíngüe e bicultural e por um subsistema de saúde indígena culturalmente sensível.

Ao contrário da arraigada desconfiança dos militares, para os quais a movimentação indígena representa uma ameaça à integridade da nação brasileira, as práticas atuais das entidades rionegrinas parecem se encaminhar para um rumo oposto. A bandeira da autonomia permanece íntegra, mas se tem observado uma ampliação progressiva, embora lenta e freqüentemente contraditória, dos vínculos com o poder de Estado, que não se reduzem, porém, a uma forma simplista de subordinação. As lideranças rionegrinas se orgulham de sua habilidade em ocupar espaços de negociação com o poder de Estado, mas existe uma atenta vigilância exercida particularmente pelos adversários dos dirigentes em exercício de cargos eletivos - com o intuito de flagrar quaisquer sinais de subalternização às práticas estatais e mesmo das entidades assessoras. Denúncias com este teor têm significância para os liderados e já custaram mais de um mandato.

Nos últimos anos, a Foirn tem executado várias ações de políticas públicas, que lhes foram delegadas por intermédio de ativas negociações feitas pelas lideranças ou pela ocupação de nichos de recursos e poder acessíveis nas instituições, mas nunca antes utilizados. Dentre as políticas sociais executadas pela Federação e suas filiadas nos últimos quatro anos, podemos citar a execução da demarcação das terras feita por ela e o Instituto Sócio-Ambiental; as ações de saúde no recém-implantado Distrito Sanitário Especial Indígena; a construção, a reforma e a implantação de escolas indígenas nas comunidades com recursos do Fundef/Ministério da Educação e outras fontes não-governamentais; o projeto Balcão da Cidadania com recursos do Ministério da Justiça, que busca auxiliar na obtenção de documentos básicos e de conhecimentos sobre os direitos do cidadão e um amplo leque de atividades de desenvolvimento etno-sustentável, como a piscicultura e a comercialização de artesanato. Todas são iniciativas que surgem como alternativas a um poder de Estado que se omite na realização de suas obrigações legais. 


\section{A distritalização sanitária}

A implantação dos Distritos Sanitários Especiais é um fato ilustrativo da progressiva retração do poder de Estado, que tem viabilizado a execução de ações de saúde nas aldeias - uma atribuição legal e intransferível do governo federal mediante a contratação de serviços pelo Ministério da Saúde/Fundação Nacional de Saúde e de entidades não-governamentais para desempenhar esta tarefa.

A distritalização sanitária, iniciada em 1999, vem seguindo a via da terceirização da prestação de serviços, concretizada em todo o País por meio de convênios com entidades não-governamentais, boa parte das quais são Organizações Indígenas, contratadas para a execução integral das ações distritais de saúde. Tal iniciativa não encontra correspondente em qualquer outra área do Sistema Único de Saúde (SUS), as experiências de terceirização têm se restringido à contratação de serviços em situações específicas como atividades-meio, recursos complementares de diagnóstico e prestação de alguns serviços especializados. Embora a rede privada permaneça ocupando um espaço privilegiado na destinação de recursos do SUS, sua atuação não implica renúncia da execução direta de serviços pelo poder público, como vem ocorrendo com a saúde indígena. Esta decisão política restringe o cumprimento dos princípios constitucionais que atribuem ao Governo Federal a responsabilidade plena pela gestão do subsistema de saúde indígena.

Analisando as relações entre o Estado e o terceiro setor, ${ }^{63}$ Magalhães (2000) demonstra que no contexto neoliberal brasileiro vem se instalando um processo de redução do Estado, com repasse progressivo de suas funções públicas para entidades civis, como as Organizações Sociais e as atuais Organizações da Sociedade Civil de Interesse Público (Oscip), que passam a se pautar pelo atendimento a interesses do Estado ao serem encarregadas da execução de políticas públicas. O processo é potencialmente capaz de conduzir a um incremento da democratização da sociedade e da capacidade de intervenção nas políticas públicas por grupos civis organizados, que buscam a redução de assimetrias econômicas e sociais. Além disso, a captação de recursos pela terceirização pode propiciar um fortalecimento institucional e um aprimoramento da gestão administrativa dessas entidades civis, podendo resultar numa maior capacidade de intervenção no cenário social (Magalhães, 2000:42-54).

Entretanto, o deslocamento de poder também implica uma desconstrução do aparelho estatal e, no caso da saúde, uma impossibilidade de funcionamento adequado do sistema de saúde, cujas ações e serviços por serem pulverizadas tendem a gerar descoordenação, ineficiência e ineficácia. O modelo terceirizado tampouco afasta o risco de corrupção, além de instaurar a necessidade de um acompanhamento técnico minucioso das ações conveniadas, para as quais os órgãos públicos não têm atualmente um preparo apropriado. 
Magalhães (2000:47) assinala outra importante conseqüência, ao repassar a responsabilidade da execução, o poder de Estado afasta de si a cobrança dos destinatários do serviço a ser prestado; por sua vez, a entidade civil captadora dos recursos passa a sofrer uma dupla pressão, a dos usuários e a do financiador. $\mathrm{O}$ autor assinala ainda a superposição de papéis do terceirizado, que passa a atuar simultaneamente como 'organização militante', isto é, em luta pelos direitos sociais, e como uma 'organização profissional', ou seja, uma entidade prestadora de serviços sociais, cujo acesso a organização militante procura garantir.

As características descritas por Magalhães são bastante convenientes para direcionar a análise das relações entre as Organizações Indígenas que assumiram convênios com o Ministério da Saúde para executar as ações distritalizadas nas áreas indígenas. ${ }^{64} \mathrm{~A}$ vinculação das entidades à proposta de terceirização do Ministério da Saúde gera uma influência direta desta política de governo sobre as condições de vida da maior parte dos povos indígenas da Amazônia legal, área sobre a qual incidem as atenções e interesses da sociedade globalizada.

Ao contrário de outras grandes Organizações Indígenas da região Norte da Amazônia brasileira, que aceitaram integralmente a terceirização das ações de saúde, a direção da Foirn (e provavelmente também seus assessores não-índios) se mostrou inicialmente relutante em firmar um convênio para a execução de serviços de saúde nas aldeias, limitando-se a pactuar o recebimento de recursos para execução de atividades de controle social, isto é, o acompanhamento e a fiscalização sobre a aplicação dos recursos públicos e sobre a qualidade dos serviços prestados pelas ONGs não-indígenas encarregadas da prestação de cuidados de saúde nas aldeias. Ao longo dos últimos três anos, a Federação foi sendo paulatinamente pressionada a assumir também as responsabilidades na prestação de cuidados de saúde, de tal forma que no ano de 2002 a Foirn recebeu os encargos e recursos para efetuar o atendimento para mais de $70 \%$ da população indígena aldeada do Alto Rio Negro, ficando, a partir de 2003, com a total responsabilidade pela assistência às comunidades.

Essa nova condição gera um redimensionamento, deliberado ou não, do perfil de atuação da entidade, que se obriga a efetuar um aprimoramento de sua gestão administrativa, de modo a responder às complexas demandas de programação e de prestação de contas de recursos públicos. Além disso, os dirigentes passam a enfrentar uma inusitada situação de coordenar a atuação de um grande número de profissionais de saúde, como médicos, enfermeiros e odontólogos contratados para o desenvolvimento das obrigações conveniais, que trazem para o espaço das relações etnopolíticas suas demandas e lógicas próprias de atuação, as quais nem sempre se harmonizam com as prioridades políticas da entidade.

As novas tarefas da Federação também geram impacto na geopolítica e economia locais. Atualmente, a Foirn é a segunda maior empregadora em saúde no 
município de São Gabriel, ficando atrás apenas das Forças Armadas. O impacto dos recursos de saúde na economia do município e nas relações internas da entidade pode ser mensurado a partir dos seguintes dados: em 2001, o orçamento aplicado pela Foirn em suas atividades não-sanitárias foi de $\mathrm{R} \$ 531.150,33$ e o recurso oriundo do convênio firmado com a Funasa foi da ordem de $\mathrm{R} \$ 2.900 .000,00$, ou seja, quase cinco vezes maior que o orçamento destinado ao trabalho político geral. Em 2002, o convênio de saúde pulou para $R \$ 5.700 .000,00$, pois a Foirn assumiu a responsabilidade da assistência de toda a área indígena do município de São Gabriel da Cachoeira, exceto calha do Rio Negro e Xié, que ficaram sob a responsabilidade da Diocese. No mesmo ano o orçamento da Federação não chegou a atingir R\$ 600.000,00.

O montante total de recursos captados para a saúde indígena pelo Distrito Sanitário do Rio Negro, compreendendo ações sanitárias nos municípios de São Gabriel, Santa Izabel e Barcelos, corresponde a R $\$ 11.700 .000,00$ para 2002. Se considerarmos uma população estimada de 28 mil pessoas que devem receber atendimento, teremos uma previsão de gasto de $\mathrm{R} \$ 417,8$ per capita/ano, quase três vezes acima da média de gasto brasileiro para os não-índios, que foi de $\mathrm{R} \$ 156,00$ per capita/ano em 2001, e 41 vezes acima do que as Secretarias Municipais de Saúde recebem do Ministério da Saúde, que habitualmente repassa para os sistemas municipalizados o montante de $\mathrm{R} \$ 10,00$ per capita/ano.

A magnitude desses recursos cobra um preço em termos de tempo e atenção voltados para uma atividade especializada, como a prestação de serviços de saúde. Tais eventos ainda são muito recentes para que se possa ter uma dimensão adequada de suas conseqüências no campo etnopolítico, mas desde já é possível delinear o peso que o convênio de saúde tem no quadro geral de atividades da Federação. As responsabilidades geradas pelas funções sociais da ação sanitária, pela complexidade técnica das ações programadas e dos intrincados mecanismos de movimentação e prestação de contas de recursos públicos, tendem a exigir um grande esforço das pessoas e instituições, geram um risco efetivo de relegar outras atribuições da entidade a um plano secundário e de produzir uma burocracia indígena voltada para a condução de processos técnico-administrativos com pouca aderência às prioridades políticocomunais. Somente o exercício de uma grande habilidade política poderá obter um equilíbrio satisfatório entre estas funções conflitantes.

Outras potenciais conseqüências políticas enfrentadas pela Foirn se dão na interação entre seu perfil de 'organização militante' e 'organização profissional', no caso como prestadora de serviços de saúde. Quando a Federação assumiu um convênio apenas para fazer o controle social, foi sua faceta militante que predominou, pois ela passou a receber recursos para controlar e acompanhar a qualidade da execução de uma política pública de seu interesse. Na situação atual, em que ela mudou para a condição de executora de serviços de saúde, gera-se um desequilíbrio em favor da condição de organização profissional. 
Antes mesmo da chegada dos primeiros recursos do Ministério da Saúde para 2002, já se faziam sentir os reflexos políticos dessa desproporção de atribuições. O processo de negociação com a Funasa exigiu restrição de despesas e os negociadores da entidade optaram por efetuar o corte dos recursos destinados ao controle social, o que significa que, pelo menos para este ano, a opção da Federação foi a amputação de sua faceta de 'organização militante' no campo da saúde, uma vez que renunciou à possibilidade de acompanhar e controlar a aplicação de recursos destinados à população indígena. Não é desprezível a contradição presente no desempenho simultâneo das funções de organização militante e de prestadora dos serviços, cuja abrangência e qualidade a militância procura garantir, pois o formato peculiar da terceirização da saúde indígena e do funcionamento dos conselhos de saúde transforma a convenente indígena em executora e fiscalizadora de si própria. As informações disponíveis não permitiram evidenciar se as conseqüências políticas desta decisão são plenamente apreendidas pela direção da entidade.

A situação enfrentada pelas convenentes indígenas exprime uma das características contradições da interveniência de grupos organizados em processos participativos. Segundo Gohn (1988:26), participar é estar presente em atividades que já existem, com suas estruturas e finalidades, pois participação não é sinônimo de autogestão. É desta maneira que as entidades indígenas foram chamadas a participar da política de saúde, através do enquadramento a uma proposta preestabelecida cujos contornos e grandes decisões estão fora do seu alcance; sua participação não lhes confere autonomia de decisão para gerir, definir orçamentos e efetuar macroplanejamentos do subsistema de saúde indígena. Às entidades terceirizadas é facultado planejar e programar ações de saúde apenas dentro de limites orçamentários e de uma configuração de serviços preestabelecidos pelo poder público e restritos à sua realidade local/distrital. As formas de administração desses recursos públicos são igualmente exodefinidas, cabendo às Organizações adequar suas estruturas administrativas para responder às exigências de aquisição de insumos, contratação de pessoal, prestação de serviços e de contas. A este respeito os dirigentes da Funasa têm uma postura transparente, pois costumam relembrar em seus pronunciamentos públicos que as entidades terceirizadas estão cumprindo uma política de governo, devendo então adequar suas estratégias de funcionamento às disposições legalmente estabelecidas neste campo.

Novas configurações de ação demandam novos perfis de gerência, exigindo, além dos saberes já apreendidos no contato com as parcerias de cooperação internacional, a formação de quadros com habilitação técnico-administrativa, capazes de conduzir processos de captação e circulação de bens e serviços que anteriormente não compunham a grade habitual de atuação das Organizações Indígenas. A trajetória dos dirigentes evidencia um ativo aprendizado da linguagem e estratégias da tecnoburocracia, do manejo de instrumentos administrativos e 
técnicas de gestão, como via de apropriação da lógica institucional de entidades públicas, particularmente da saúde.

As contradições da terceirização são reeditadas no próprio seio do movimento indígena. A opção por uma parceria com o Estado para a execução de funções públicas lança sobre a Organização Indígena também o ônus do desmanche do Estado brasileiro, pois nesse momento ele assume funções constitucionais das quais o poder de Estado tenta se eximir (Magalhães, 2000). O processo gera um atrelamento, ainda que involuntário, a prioridades políticas definidas nas esferas de governo e molda o funcionamento da entidade a planos, metas, prazos e orçamentos que violentam seu ritmo de trabalho e seus propósitos de atuação.

Atrasos no repasse de recursos, cortes de orçamento, conflitos trabalhistas e problemas decorrentes do mau funcionamento de outros níveis do Sistema Único de Saúde passam a onerar politicamente a prestadora de serviços, deixando os órgãos de governo a salvo das críticas e insatisfação dos usuários. A recepção da responsabilidade de efetuar o controle social, associada à opção de corte de recursos para fazê-lo, remete a Foirn para uma curiosa encruzilhada ética, pois a entidade assume a responsabilidade de fiscalizar a si mesma e renuncia aos meios para executar a fiscalização. Trata-se de uma nuance delicada, mas decisiva, pois aqui se borra completamente a clássica oposição 'nós', índios, contra 'eles', órgãos de governo, que não cumprem suas atribuições legais, podendo a própria Organização Indígena ser responsabilizada e vitimizada pelos eventuais fracassos.

No Sistema Único de Saúde brasileiro, a participação da sociedade civil é viabilizada sobretudo por meio de colegiados (conselhos de saúde), cujo caráter deliberativo instaura um processo de gestão dos recursos públicos, com o objetivo de corrigir e aprimorar o funcionamento de instituições pautadas por prioridades definidas pelo governo e que devem ser ajustadas às realidades locais. Um dos maiores desafios enfrentados por conselhos e conselheiros é a complexidade dos temas enfrentados, aliada à escassa qualificação de profissionais e usuários, índios e não-índios, para efetuar os processos de gestão requeridos e viabilizar um acompanhamento eficaz dos procedimentos técnicos empregados nos Distritos Sanitários. O desafio dessa forma de participação é superar a condição de correia de transmissão de decisões políticas oriundas do poder de Estado e lograr um nível de representatividade capaz de elaborar propostas autônomas, redimensionadoras da produção e gestão de políticas públicas e que se mostrem capazes de atender às prioridades e necessidades da população.

Outro problema enfrentado pelos conselhos é que sua lógica de funcionamento é etnocêntrica, dimensionada pela idéia de participação de indivíduos, consumidores/usuários de serviços de saúde, comprometidos com uma democracia 
universal, a serviço de cidadãos isonômicos. Essas instâncias colegiadas não se adequam à estrutura indígena de parentesco centrada na pessoa, e não no indivíduo gerando obrigações e responsabilidades específicas desta condição; dessa forma, a presença de um representante tukano ou baniwa num conselho de saúde, tomada como sinônimo de defesa dos interesses de todos os membros do grupo étnico, não faz jus à sua condição real de participação, pois ali ele fala em nome de um número muito restrito de pessoas e não recebe, como já foi visto anteriormente, delegação de poder para decidir por seus representados.

Em sua atuação, o conselheiro indígena de saúde é obrigado a harmonizar noções contraditórias de democracia universal e hierarquia ritual. A instável conciliação entre diferentes lógicas políticas neste espaço de mediação interétnica deixa o conselheiro de saúde numa difícil encruzilhada entre necessidades universais de saúde e suas obrigações particulares em relação dos consangüíneos. A observação do funcionamento regular dos conselhos tem demonstrado a tendência dos representantes indígenas de priorizar as demandas de seu grupo de parentesco e particularmente dos co-residentes, especialmente nas situações que envolvam acesso a recursos de saúde. No campo das relações interétnicas, a participação nos colegiados de saúde assume, não raro, um caráter de desforra cada vez que os representantes indígenas conseguem aprovar suas propostas, em detrimento das posições dos representantes institucionais não-indígenas.

Como em qualquer processo social, este também não é uma via de mão única e nem o Estado é um bloco monolítico, isento de contradições. A participação indígena gera permanentemente contradições internas e incertezas e as adiciona às iniciativas do Estado, pois os sujeitos sociais imprimem nelas suas marcas e prioridades, efetuando redimensionamentos diversos nos espaços de participação, que costumam ser alargados à revelia dos seus propositores. Os processos de negociação instaurados no campo da saúde também propiciam o acúmulo de experiências e competências aplicáveis a outros campos de sua atuação, algo rapidamente percebido pelas lideranças, que avaliam de forma positiva o aprimoramento da estrutura administrativa de suas entidades e os saberes adquiridos nos penosos processos de negociação com o Ministério da Saúde.

A Foirn não está sozinha no caminho aberto pela terceirização; sua posição, retardatária em relação a outras Organizações Indígenas, é de cautela ante as iniciativas governamentais. Cabe perguntar sobre as razões que têm levado os dirigentes indígenas a adotar uma opção de alto risco político para o movimento indígena e aceitar uma interação tão profunda e complementar com instituições de um poder de Estado, contra o qual a história do movimento tem se configurado contrastivamente.

A primeira pista para tal decisão política aparece num documento elaborado por líderes indígenas, no contexto de uma guerra de posições e de 
interpretações dos conflitos políticos ocorridos na comemoração dos 500 anos de descoberta do Brasil, no ano de 2000 . Os signatários, ${ }^{65}$ entre os quais encontramos o representante da Foirn, são dirigentes das maiores e mais institucionalizadas Organizações Indígenas no País e respondem ao Conselho Indigenista Missionário, que os acusara em carta anterior de terem sido cooptados pelo governo; historiam e justificam suas posições no trecho transcrito a seguir:

Atuou-se para que a participação indígena deixe de ser apenas decorativa para que possamos assumir nossas responsabilidades. Articulações, convênios foram firmados na perspectiva de promover a melhoria de vida para as populações indígenas de todo país. Mais recentemente, várias organizações passaram a manter Convênio com a Fundação Nacional de Saúde na perspectiva de modificar o triste quadro de saúde dos povos indígenas; cansados de analisar os relatórios anuais do Cimi a respeito das "violências contra os povos indígenas", procuramos mudar o curso da história e dos acontecimentos na vida cotidiana das aldeias. Por assinarmos os convênios com a Fundação Nacional de Saúde, fomos duramente criticados pelo Cimi, que não concorda que as Organizações Indígenas atuem na prestação de serviços de saúde, alegando que esta é uma política de terceirização (Povos Indígenas no Brasil, 2000:74)

A posição política veiculada na carta das lideranças reflete o momento organizativo dessas entidades, que buscam uma vinculação mais objetiva com as necessidades da vida aldeã do que as clássicas bandeiras do movimento indígena permitem. O esvaziamento da bandeira de luta da demarcação, hoje resolvida na maior parte dos grandes territórios indígenas amazônicos, gera a necessidade de novos campos de consenso capazes de manter a aglutinação dos sujeitos sociais aos projetos do movimento etnopolítico. Aqui a etnicidade política se transfigura em necessidade técnica, capaz de gerar produtos visíveis e palpáveis de saúde, educação e auto-sustentação, entre outros. A chamada 'etnicidade de resultados' é uma forma de ação política, mais pragmática decerto, mas legitimada pelas pressões oriundas das aldeias, que empurram as diretorias das Organizações para a busca de novos espaços de poder, buscando viabilizar a resolução de problemas.e propostas de transformação da sociedade através da própria iniciativa indígena, numa clara demonstração de descrédito da capacidade ou desejo do Estado em fazê-lo.

Esta posição é reforçada por uma avaliação indígena do processo de distritalização sanitária, feita em evento organizado pela Coiab no ano de 2001, que contou com a participação de todos os gerentes indígenas dos convênios firmados com a Funasa. 
... nossa idéia desse debate é para discutir o que está acontecendo, problemas que tivemos e a reação de nossas Organizações... em alguns lugares tivemos problemas políticos seríssimos com essa coisa de terceirização e neoliberalismo, mas lá na ponta, na comunidade, está o agente de saúde, trabalhando com sua radiofonia; os médicos passando por lá, fazendo atendimento, fazendo alguma coisa pelo povo que jamais se viu lá... Com isso, algumas organizações não gostaram, disseram que a gente agora tinha contrato e que agora o governo ia ditar regra para fazer o trabalho, que estávamos em risco porque assumimos toda a responsabilidade administrativa e iríamos receber toda a reclamação dos povos... então aparentemente é uma coisa assim tão complicada porque a gente nunca tinha trabalhado nisso, mas se você for perceber, aos poucos o povo e as lideranças, todos estão aprendendo... (presidente da Coiab)

A fala transcrita foi pronunciada na abertura do evento ocorrido mais de um ano depois dos conflitos de Coroa Vermelha; seu teor representa uma continuidade lógica com o documento que reproduzimos e uma posição compartilhada por todos os dirigentes indígenas que se posicionaram naquele encontro.

Os aspectos políticos mais gerais que envolvem a participação na terceirização apontam também para a possibilidade de desconstrução do estigma da tutela e da incapacidade política e intelectual que lhes foi atribuída pelo mundo do branco no processo colonizatório. O reconhecimento das Organizações Indígenas como parceiras efetivas pelo Ministério da Saúde instaura a possibilidade de um protagonismo que as traz para o centro de uma cena política na qual, graças ao indigenismo oficial - que chegava mesmo a se negar a reconhecer a sua existência jurídica -, sempre ocuparam um lugar secundário. As potencialidades desta conjuntura foram rapidamente apreendidas pelos dirigentes e contribuíram para sua decisão de assumir a arriscada proposta da terceirização; o discurso do representante da Foirn no mesmo evento ilustra claramente essa idéia.

A Foirn é uma Organização Indígena que foi fundada em 87 e, com o decorrer dos anos, foi crescendo suas atividades, haja visto que era só discussão política teórica que se fazia; os governantes não tomavam posição em relação às comunidades, então por isso é que as lideranças indígenas resolveram dar meios de ação para a Foirn, para que se pudesse colocar em prática, para mostrar para o poder público que é possível fazer as coisas...É neste sentido que a Foirn, além de outros convênios que ela já tinha com agências estrangeiras, também fez convênio com o governo. Esse convênio permitiu fazer muitos trabalhos de saúde nas comunidades, mas também contribuiu para a política indígena porque, nesta mobilização comunitária para discutir política de saúde, também se discute projetos de interesse do movimento indígena. Neste sentido, o convênio que a Foirn tem com o governo ... dá mais força para o movimento indígena para se capacitar para entender melhor de política de saúde e de 
administração. Então a gente vê o outro lado... (representante da Foirn, no fórum de avaliação da distritalização promovido pela Coiab)

As falas mostram a preocupação de dirigentes que, por força do ofício, devem lidar simultaneamente com localismos e globalismos, conjugando intervenções dirigidas a temas muito amplos com o ônus político de partilhar o processo de terceirização e com a necessidade de desenvolver ações comunais concretas. A mudança do paradigma que orienta a atuação do movimento etnopolítico no campo da saúde é perceptível nas histórias e necessidades por ele vivenciadas e potencializada por uma eficiente apropriação dos conceitos e propósitos da reforma sanitária brasileira. As formas de intervenção social das lideranças indígenas evidenciam os propósitos de assumir o protagonismo na implantação do modelo de distritalização sanitária indígena, apesar das dificuldades e percalços que vêm enfrentando. Percebendo também a multipotencialidade do processo, planejam obter através do mesmo uma intensificação de bandeiras políticas gerais do movimento indígena, numa intervenção contraditória, em que a utopia da autodeterminação é alimentada pela vinculação com o poder de Estado.

$\mathrm{O}$ tema remete à questão da autonomia possível aos povos indígenas nos cenários amazônicos. A este respeito, Smith (1987) interroga que constelação de interesses cerca uma Organização Indígena e que liberdade de ação ela tem ante as pressões de partidos políticos, donos de terras, igrejas etc. Na realidade rionegrina não se pode falar em completa autonomia do movimento indígena, subsumido como está às determinações da sociedade global, que conjunturalmente lhe empresta apoio e visibilidade em detrimento dos interesses de um desenvolvimentismo rudimentar da burguesia regional, mas não se evidencia uma subordinação importante a nenhum ator político específico das atividades desenvolvidas pela Foirn na condução de suas rotinas e programações.

$\mathrm{Na}$ vigência dessa autonomia relativa, vale a pena assinalar a independência ante ao órgão indigenista oficial, favorecida pela obtenção de recursos próprios para sustentar suas atividades políticas e de desenvolvimento econômico, gerando renda e/ou melhorando o acesso aos bens de consumo para seus liderados. Além disso, suas alianças têm lhes propiciado acesso a meios jurídicos - entre os quais a própria legalização de suas filiadas - capazes de representá-los diretamente, dispensando, ou mesmo se opondo, a mediação do órgão indigenista. 
59 Dada a vasta literatura produzida sobre a globalização e ambientalismo, não vamos nos deter sobre o tema, remetendo a discussão para Ianni (1995, 1996), Ortiz (1992, 1994, s.d.), Chesneaux (1996), Leis (1991), Viola (1996) e Latouche (1996).

œ Ortiz (1994:31) distingue a mundialização como processo, que nos remete mais diretamente à produção e reprodução de práticas sociais e à atuação de atores sociais concretos em suas relações cotidianas, de mundialização como totalidade, que é por ele caracterizada como um "conjunto extranacional de fenômenos sociais específicos e comuns a várias sociedades", que, neste caso, equivaleria à idéia de globalização. A base territorial da cultura mundializada seria o próprio planeta, que comportaria, no entanto, em seu seio a heterogeneidade e a pluralidade.

61 O termo 'ponto de vista' está sendo aqui utilizado em seu sentido literal, isto é, aquele ponto a partir do qual um sujeito observa, representa e enuncia juízos sobre o meio social onde atua.

62 As chamadas reuniões do Conselho Administrativo da Foirn/CAF são, na verdade, grandes assembléias que podem chegar a congregar mais de 300 participantes e costumam ocorrer semestralmente, comportando eventualmente algumas reuniões extraordinárias no intervalo entre elas.

63 Fernandes (1994:21) caracteriza o terceiro setor como "um conjunto de organizações e iniciativas privadas que visam à produção de bens e serviços públicos".

$64 \mathrm{O}$ impacto desta relação pode ser dimensionado ao considerarmos o perfil dos 11 convenentes indígenas na Amazônia, que são entidades de grande alcance regional, recobrindo realidades multiétnicas que agregam os povos indígenas de Roraima (Conselho Indígena de Roraima/CIR), Rondônia (Coordenação das Nações e Povos Indígenas dos Estados de Rondônia, Norte do Mato Grosso e Sul do Amazonas/Cunpir), Alto Solimões (Organização Töru Möru/OTM), Vale do Javari (Conselho Indígena do Vale do Javari/Civaja), Alto Rio Negro (Foirn), Médio Solimões (União das Nações Indígenas de Tefé/UNI-Tefé), Alto Juruá e Alto Purús/Acre (União das Nações Indígenas do Acre/UNI-Acre), Médio Purus (Organização dos Povos Indígenas do Médio Purús/ Opimp), Amapá (Associação dos Povos Indígenas do Oiapoque/Apio) e Coordenação das Organizações Indígenas da Amazônia Brasileira/Coiab, totalizando mais da metade dos povos indígenas da Amazônia legal. Tais Organizações são as maiores, mais estruturadas e experientes nas lutas etnopolíticas travadas nas duas últimas décadas.

65 .Dos 25 signatários deste documento, 14 deles têm ligações diretas com a gestão dos convênios estabelecidos com o Ministério da Saúde. 
Após essa incursão pelo cenário mais amplo do movimento indígena, cabe retomar a análise de como essa realidade se expressa no plano local do complexo Içana/Aiari.

Questões importantes nas análises gerais do movimento indígena como 'autenticidade', 'indianidade', 'identidade' não encontram grande eco numa realidade marcada pelas interações frátricas e na qual não proliferam as dúvidas sobre a identidade étnica, mesmo que alguns possam lamentá-la. Não se observa grande tolerância com lideranças que, negociando em nome dos Baniwa, sejam capazes de obter bens ou serviços para o conjunto da população, mas falhem na obtenção de resultados palpáveis para seu grupo de consangüíneos e/ou residentes próximos; as conquistas direcionadas para outras fratrias tendem a acirrar as tensões entre elas, já que a identidade genérica de 'Baniwa' não é operativa nas relações do dia-a-dia.

Um espaço sociopolítico em que as epidemias, mortes súbitas e acidentais costumam ser interpretadas como fruto da ação de pajés uaupesinos não comporta harmonicamente a noção de um pan-indigenismo rionegrino. Concessões a uma identidade genérica costumam ser toleradas como estratégias de atuação direcionadas 'para fora' da reserva, podendo se prolongar, caso redundem em resultados apreciados. No âmbito comunal as rivalidades clânicas, as relações de poder fundadas no controle de gênero e de geração têm prioridade absoluta na cena social e geram um desafio permanente: o de como constituir entidades supracomunais capazes de defender - por exigência de atores políticos nãoindígenas, que, por desconhecimento ou desinteresse pela variedade e diversidade dessas culturas, só legitimam temas e interesses supralocais - posições unificadas, num universo em que a única unidade aceitável é restrita à consangüinidade.

Não se deve, porém, desprezar a capacidade performativa dos símbolos em criar realidades e redimensionar instituições e práticas autóctones; as estratégias de apagamento temporário de identidades vêm produzindo persistentes reflexos nas formas de auto-identificação nas aldeias, onde pessoas imersas nas identidades clânicas aprendem também a se interessar e buscar/prover apoio para que suas 
entidades lutem pelos interesses dos 'Baniwa' na Foirn, em São Gabriel, em oposição aos Tukano, aos brancos e outros.

A relevância obtida pela discussão sobre 'autenticidade da cultura' e 'identidade étnica' fora das fronteiras do mundo baniwa e a escassa repercussão desses temas dentro das áreas demarcadas é uma amostra da diversidade da visão de mundo dos membros de gerações mais velhas, detentores dos meios simbólicos de reprodução da sociedade, e a dos líderes das Organizações etnopolíticas, mais jovens e menos legitimados no mundo da aldeia. $\mathrm{Na}$ busca de ampliar sua legitimidade, estes têm desenvolvido criativos sistemas de comunicação pelos quais tentam fazer os velhos entenderem os propósitos e atividades de suas entidades, se esforçando em construir uma atuação diferenciada dos líderes populistas e clientelistas que desempenharam, outrora, papéis sociais que guardam semelhança com os assumidos pela Organização Indígena.

As negociações em torno da política identitária implicam também uma manipulação dos novos conteúdos aprendidos no movimento indígena, na busca de enfrentar os desafios cotidianos dentro e fora das aldeias. No mundo nãoindígena, as lideranças aprendem a importância da diferença étnica, a moeda de troca capaz de ampliar seu poder de intervenção no mundo globalizado; entretanto, nas aldeias seus liderados encaram demarcadores culturais como as pinturas corporais, adornos, malocas e rituais de passagem, como uma volta, por eles indesejada, a um estado de violência e selvageria. Nos dias atuais, a roupa é um elemento constitutivo da identidade social, mais um dos sinais de distinção, de urbanidade e de harmonização que, no seu entender, a sociedade baniwa deve buscar. Roupas e outros estigmas da ocidentalização são encarados como sinais de uma vida social bem instaurada e recolocam os sujeitos num patamar de civilidade que os afasta dos tempos de caos primordial. Este conflito de posições deixa as lideranças num impasse, que instaura um processo de negociação de prioridades entre as exigências de cada um dos pólos dessa relação.

Como exemplo bem-sucedido do esforço de negociação de prioridades pelos líderes do movimento indígena, retomaremos a análise das atividades do Projeto de Medicina Tradicional Baniwa, coordenadas pela Oibi; o choque de perspectivas pode ser evidenciado na construção de uma maloca pela segunda diretoria da Acira e destinada a ser a sede da entidade.

A primeira iniciativa surgiu de uma preocupação das lideranças da Oibi em diversificar a capacitação dos agentes de saúde, centrada em conteúdos de biomedicina, ignorando os sistemas indígenas de doença e cura e gerando um risco potencial de desvalorização das práticas de medicina tradicional baniwa. $O$ desenvolvimento deste projeto, uma temática valorizada nas bandeiras do movimento indígena, enfrentava um sério risco de rejeição da base evangélica da 
Oibi, uma vez que o tema doença/cura remete às ligações com o xamanismo e os donos de cânticos, elementos recusados na conversão à religião protestante.

Entretanto, as lideranças sabiam que uma discussão inicial sobre as doenças podia não ser aceita, mas um treinamento centrado no uso de plantas medicinais seria bem recebido, pois estas são meios de cura correntemente utilizados nas comunidades evangélicas e havia uma preocupação dos mais velhos com a interrupção da transmissão de tais saberes para as gerações mais jovens. A partir dessa avaliação preliminar, a entidade iniciou o projeto, obtendo um apoio gradativo dos velhos para a ampliação do trabalho até a obtenção de um clima adequado para a livre discussão do tema de doenças.

Ao longo de quatro anos, o trabalho exigiu a identificação e a sensibilização de detentores de saberes sobre doença e cura, que pudessem apoiar os agentes indígenas de saúde nessa temática e estabelecer com eles uma parceria permanente, garantindo uma continuidade ampliada do processo de capacitação no espaço familiar; paralelamente, foi efetuado um registro escrito de informações consideradas pelos velhos como adequadas à circulação pública, além de se discutir estratégias socioculturalmente aceitáveis de comercialização de plantas medicinais sem uma violação de seu caráter sagrado e/ou secreto. Neste caso, a decisão coletiva foi de iniciar os estudos, visando à futura comercialização de plantas destinadas a finalidades cosméticas, tendo em vista os entraves gerados pela sacralidade dos saberes e plantas destinados à cura e a falta de proteção adequada aos direitos de propriedade intelectual dos conhecimentos indígenas.

O conjunto de ações desenvolvidas produziu uma revalorização do papel dos velhos no campo da saúde, um reforço ao controle do trabalho dos agentes de saúde e um incremento do apoio dos idosos às iniciativas da Organização de Base, propiciando uma inesperada consolidação da aliança entre os dirigentes da entidade, benzedores e conhecedores de plantas medicinais; além disso, a possibilidade de comercialização de plantas cosméticas ampliou o apoio político a estas atividades, face à perspectiva de geração de renda daí advinda. $\mathrm{O}$ capital simbólico ${ }^{66}$ da Oibi, traduzido no "poder de fazer crer" na revalorização da etnicidade, pôde competir, neste caso, de forma satisfatória com as estratégias de negação cultural, própria das influênoias políticas alheias ao movimento indígena (Bourdieu, 1989).

Por outro lado, a iniciativa da Acira em construir uma maloca em Canadá, aldeia walipere dakenai, evangélica e sede da entidade no Aiari, não obteve o resultado desejado; na ótica dos capitães daquela região, a maloca, longe de representar um símbolo valorizado da cultura, se associa a um 'tempo de atraso', remetendo a um renegado período pré-civilizatório; além disso, a maloca construída por uma diretoria católica numa aldeia evangélica provocou uma reagudização de conflitos religiosos latentes, pois sua mera presença evoca os rituais abandonados 
no processo de conversão. Como resultado prático deste embate, ela foi rejeitada como local adequado para a realização de reuniões e assembléias da entidade; sem uso, foi abandonada e vem se deteriorando lentamente. $\mathrm{O}$ episódio demonstra que o sucesso das iniciativas das lideranças de base depende muito de sua capacidade de negociação e de convencimento dos liderados, da justeza das bandeiras de revitalização étnica veiculadas pelo movimento indígena.

É perceptível a existência de uma lacuna entre os saberes das gerações mais velhas e os dos mais jovens, particularmente os que não militam no movimento etnopolítico; nas aldeias existe um grande número de pessoas que desconhecem muitos aspectos básicos de sua cultura, não dispondo dos meios de reproduzi-las para as futuras gerações. No descompasso entre as idéias de valorização da antiga cultura e o desejo, freqüentemente expresso pelos capitães, de 'progredir' e 'ir para frente' - termos tomados como sinônimo de abandono das evidências de diferenciação étnica e de adoção de pautas ocidentalizantes de comportamento -, a influência da escola é decisiva para incrementar o processo de desvalorização dos saberes próprios do mundo indígena (Weigel, 2001). Entretanto, a retomada do interesse pela diferenciação cultural já se faz visível em vários campos da sociedade, surgindo como o desejo de aprender os mitos, a retomada da produção de cestaria e da nomeação de crianças com nomes da geração dos avós. Iniciativas como o Projeto de Medicina Tradicional e a Escola Baniwa querem atingir este grupo populacional, buscando uma restauração da experiência dos antepassados e uma sensibilização para a importância da consciência étnica.

A revitalização de elementos da etnicidade na área baniwa - como, por exemplo, a revalorização da hierarquia de sibs - é atribuída tanto a uma conquista do movimento indígena, quanto à falta inicial de parâmetros de orientação frente à criação de novos papéis sociais produzidos na fronteira das relações interétnicas. Diante do confronto com o inusitado, a tendência seria lançar mão do processo de 'ancoragem' no qual se procuram pontos de referência no acervo pré-disponível na cultura, em busca de orientação para a ação; nessa conjuntura, a busca de antigas formas de classificar e distribuir pessoas e papéis sociais pode oferecer parâmetros para a escolha de representantes e para a tomada de decisão.

\section{Relações com o poder de Estado}

No trabalho dos dirigentes das Organizações locais, é nítida a tensão entre o papel de articulador político de lutas mais gerais pelos direitos de cidadania e/ou ligados à diferença étnica e o atendimento a solicitações individuais de combustível, fornos de farinha, implementos agrícolas e remoção de doentes. De muitas formas, as Organizações Indígenas suprem a ausência do aviador, mas principalmente estão 
sendo chamadas a ocupar as funções de políticas públicas que não se interiorizam nas áreas indígenas. Elas também entram num campo direto de competição com o populismo político-partidário que atua numa vertente análoga. $\mathrm{O}$ eixo de atuação política das entidades compreende a interação de diversos campos de ação social onde oscilam permanentemente as disputas individuais e coletivas, a ordem e a desordem, a manutenção e o redimensionamento da ordem social.

Essas múltiplas atribuições aguçam a confusão estabelecida em torno das funções e responsabilidades sociais das Organizações Indígenas por parte de um conjunto de liderados que tem uma visão muito fragmentária da estrutura, funcionamento e contradições das instituições não-indígenas que regulam a vida dentro e fora da terra indígena. Dentre as estratégias priorizadas no circuito comunicativo entre lideranças e base, destaca-se a busca incessante de explicar como está organizado o mundo 'lá fora', buscando, dentre outras coisas, limitar o volume e a intensidade de cobranças que incidem sobre a Organização quando as políticas públicas falham ou estão ausentes.

As iniciativas para tornar as instituições da sociedade nacional mais inteligíveis para as pessoas nas aldeias podem ser observadas na análise de um relatório de 1999, da Oibi. Na primeira parte deste relatório, observa-se a descrição de uma atividade destinada a explicar para os participantes de um treinamento agentes de saúde, professores, capitães e lideranças de Organizações de base baniwa e Curipaco - as características das políticas de saúde do Estado brasileiro. No momento inicial do relato, uma liderança tenta explicar o que é uma política pública, a origem dos recursos para viabilizá-la e as distorções que podem ocorrer na concretização das atividades. $\mathrm{O}$ relato diz literalmente o seguinte:

Esta parte foi dado aula pelo presidente da Oibi com a dinâmica da farinha, que se procedeu cada um trazendo um pouco de farinha em cuia ou caneco, taça, prato ou panela para ser juntado em um urutu grande, que representou a arrecadação e cofre público federal, estadual ou municipal. Depois foi pego três vasilhames com tamanhos diferentes, capacidades diferentes de farinha, um cheio, outro mais ou menos cheio e outro nada cheio. (Os) Vasilhames representam porcentagens de distribuição de recursos dos governos para os ministérios ou secretarias. ... Muitas vezes eles nem repassam os recursos. Outras vezes o recurso repassado é desviado. O recurso não é do governo. $O$ dinheiro é do povo. O governo e seus subordinados são pagos pelo dinheiro do povo. O governo apenas foi confiado para administrar o recurso do povo para melhorar sua saúde, educação etc. A partir dessa dinâmica é que foi possível explicar a situação de São Gabriel e o que acontece no Conselho Municipal de Saúde....Com a mesma dinâmica foi explicado o sistema atual de repasse de recurso para a saúde do índio, que passa do Estado para depois passar para São Gabriel por exemplo, e muitas vezes o recurso não passa, é desviado... (Relatório de treinamento da Oibi, 1999) 
O trecho transcrito mostra o esforço, por meio de um recurso analógico que utiliza imagens familiares às pessoas das aldeias, em explicar sofisticados conceitos como política pública, distribuição percentual de recursos e má aplicação dos mesmos. O monitor do treinamento se esforça por estabelecer um campo de interlocução com suas bases políticas, de forma a tornar mais evidente a razão de suas lutas e a necessidade de ampliar a organização política indígena. Aqui a liderança atua como um agente intercultural, efetuando a mediação entre o mundo da aldeia e a sociedade envolvente (Bartolomé, 1995).

Com freqüência, os jovens líderes se queixam da dificuldade de fazer os velhos compreenderem a dinâmica de funcionamento das Organizações Indígenas e as diferenças entre esta forma de atuação e o trabalho de gestão cotidiana da vida na aldeia; eles vêm tentando superar esta defasagem através de um processo intensivo de divulgação dos saberes que consideram importantes para que aqueles possam entender e apoiar sua atuação à frente das entidades.

Nas assembléias e reuniões, tornaram-se rotineiras as explicações sobre as formas de organização e funcionamento de instituições e políticas do governo brasileiro, as nuanças que envolvem o desenvolvimento de projetos, os princípios ambientalistas e os grupos ecologistas que apóiam o trabalho da Foirn etc. Obviamente, tais iniciativas envolvem a tentativa de tornar hegemônicas as idéias desses jovens líderes sobre as formas mais adequadas de intervenção no espaço interétnico.

Em outra reunião, a diretoria da Oibi reproduz no diagrama abaixo a concepção que faz de sua própria atuação:

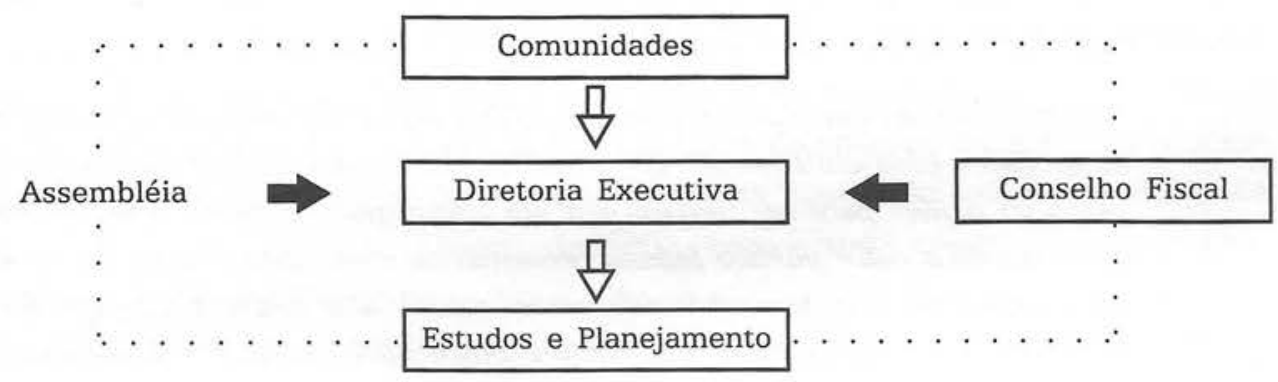

Pela ordem das setas, se pode observar que a diretoria representa a si própria como um grupo a serviço das deliberações comunitárias expressas nas assembléias, viagens de articulação e no trabalho dos conselheiros fiscais. Essa concepção de dirigente político sem poder é utilizada também nas suas representações sobre o Governo. Tal como aparece no depoimento cujo registro apresentamos, ao Governo foi apenas confiada a capacidade de administrar os recursos para implementação de políticas públicas; na área baniwa é possível ouvir com certa freqüência essa caracterização de um Governo administrador, sem poder 
de mando e dependente das vontades e decisões da população, numa amostra de como antigas matrizes culturais que expressam concepções indígenas sobre o papel da chefia adquirem sentido no momento presente, mediante uma bricolage com as mensagens supostamente democráticas do discurso político-partidário.

A bricolage da ação política se expressa em diversos planos quando, por exemplo, uma Organização como a Oibi, cujos líderes viajam com freqüência para fóruns e encontros nacionais e internacionais, busca assessoria em Universidades e ONGs ambientalistas, mas valoriza igualmente a orientação dos sábios das aldeias e inclusive os conselhos de um benzedor, tio materno de um dos diretores e detentor de alegados poderes premonitórios; este personagem atua como um conselheiro invisível, orientando, por meio de suas visões e premonições, quanto aos rumos a seguir quando se estabelecem conflitos, dentro e fora da área indígena. A ação final de uma entidade como esta é uma síntese da influência de elementos de diferentes culturas, articulados como uma totalidade na práxis de seus membros.

É um cenário que congrega códigos culturais de diversos contextos sociais, demonstrando não apenas a vinculação ao seu meio social de origem e às formas mais amplas de organização societária vigentes no planeta, mas também o desejo de síntese de registros culturais distintos, que as lideranças processam em si mesmas, na busca de interpretar o que ocorre no âmbito de sua atuação política. São exemplos de situações em que o movimento social se transforma em uma nova instituição política potencialmente capaz de criar novos quadros de referência, novas produções culturais a partir do redimensionamento das anteriores (Melucci, 1994; Tourraine, 1998).

\section{Ação e discurso no movimento indígena baniwa}

A entrada baniwa no 'mercado de projetos' está profundamente vinculada à necessidade de legitimar-se diante de seus pares, uma vez que as propostas de valorização étnica encontravam pouco eco nas relações internas.

Hoje é diferente de quando assumimos a direção da Oibi. Se você visse como a gente era recebido em certas comunidades Curipaco, em certas comunidades de Tunuí pra baixo... Porque nesses lugares eles não queriam saber do movimento, as coisas de índio para eles eram sinais de atraso; em certos lugares eu era recebido porque eu sou walipere dakenai, mas como organização Oibi, como movimento indígena eles não queriam nem que tocasse nesse assunto; eu era bem recebido, eles serviam chibé, comida, e outras coisas assim; mas para conversar sobre o movimento, sobre resgate das coisas tradicionais, das práticas culturais, essas coisas, eles não aceitavam não. Foi assim que começou o movimento, essa época nós chegamos até a ser presos no pelotão de fronteira; pegamos muitas 'porrada', por assim dizer, dos capitães 
porque a gente não era bem recebido nas comunidades. (B. J., ex-dirigente da Oibi, walipere dakenai)

Ao fim de um certo tempo a ação puramente discursiva se esgotou e os dirigentes se viram pressionados a desenvolver atividades que justificassem a existência da Organização e concretizassem seus propósitos e finalidades, o que os levou a iniciar projetos demonstrativos das potencialidades da recém-formada entidade. Como já foi relatado, uma das primeiras e bem-sucedidas iniciativas foi a implantação do trabalho dos agentes de saúde. Nos anos seguintes, diversos projetos de auto-sustentação foram desenvolvidos, com maior ou menor sucesso. O consenso atual na área baniwa é que a adesão das pessoas às propostas políticas mais gerais é condicionada ao desenvolvimento de atividades geradoras de renda e/ou de bens industrializados, configurando uma visão gerencial, na qual a Organização Indígena passa a se preocupar sobretudo com a resolução de questões concretas da vida cotidiana, reproduzindo internamente a chamada "etnicidade de resultados" (Albert, 2000).

$\mathrm{Na}$ área rionegrina, o início das atividades políticas de boa parte das Organizações de Base é marcado pela fase de doação de fornos de farinha, motores e barcos; Oibi e Acira foram capazes de cumprir o seu papel neste momento inicial, algo que se tornou mais difícil para as Organizações que se constituíram mais tardiamente devido à retração, na Foirn, de recursos para tais finalidades. Atualmente as entidades baniwa priorizam a elaboração de projetos de autosustentação e lutam contra a lógica populista estabelecida pela Funai e Prefeitura, que também privilegiam a distribuição desses bens de consumo. Pode-se dizer que elas seguiram a mudança geral de estilo que vem ocorrendo no movimento indígena, cujas formas de atuar priorizaram em certos momentos o discurso de denúncia, potencializado pelo carisma pessoal das lideranças, passando pela rotinização do carisma e se configurando hoje mais como um estilo administrativo-gerencial preocupado com a viabilização de políticas sociais nas aldeias. Não se pode dizer que as expressões iniciais foram superadas historicamente, sendo mais adequado descrever o cenário como uma convivência entre estas diferentes facetas do movimento indígena, sendo que cada uma delas pode adquirir relevância em certos momentos políticos e em outros não.

As Organizações de Base articulam a realidade da aldeia com forças políticas exteriores às terras indígenas, inaugurando novas formas de lutas pelos direitos civis, baseadas no direito à diferença étnica e no acesso a bens e serviços oriundos da aplicação de políticas públicas e do apoio de ONGs sensíveis à causa indígena. Elas buscam o estabelecimento de bandeiras coletivas capazes de substituir o vínculo afetivo/clientelista/individualizado estabelecido entre capitães e autoridades governamentais e da sociedade civil, como, por exemplo, regatões, comerciantes, 
militares, políticos. No último caso, as estratégias utilizadas, que transitavam entre o pedido humilde, o aliciamento, o compadrio e a exigência irada, mudam para o estabelecimento de relações mais objetivas, alicerçadas no direito político de pertencimento a grupos socialmente desfavorecidos e obtidas através de movimentos reivindicatórios coletivos.

\section{Clientelismo, partidos, eleições e outras habilidades interétnicas}

Numa sociedade em que o controle sobre seus membros é exercido por intermédio de uma rede capilar na qual se distribuem diversos focos de saber/poder, não existem muitos meios centralizados de coação sobre as pessoas e a subsistência cotidiana só pode ser obtida por intermédio de processos de negociação capazes de garantir a cooperação permanente dos membros do grupo e a manutenção de um sistema de trocas que garanta a circulação dos bens necessários à manutenção da vida. No passado, as trocas no espaço interétnico eram estabelecidas com o aviador ${ }^{67}$ e hoje se atualizam com parlamentares e com as lideranças de Organização Indígena.

As lideranças reclamam que os capitães cobram uma distribuição periódica de mercadorias e que tal distribuição contribui mais para seu prestígio e legitimação do que as 'falas' do movimento indígena. Se os primeiros passos de uma Organização Indígena de Base têm seguido a trilha da distribuição de bens de consumo, a seu ver o desafio consiste agora em passar para uma forma de atuação mais ampla, abandonando a mera distribuição de bens, para alcançar o desenvolvimento de projetos auto-sustentáveis que não apenas possam garantir a subsistência, mas que também logrem reinserir as comunidades no mercado, numa posição mais favorável que a de que dispunham anteriormente.

Como lembra Oliveira Filho (1987), em diversas regiões da Amazônia, a figura do capitão foi engendrada historicamente para suprir necessidades econômicas do mundo não-indígena, mas no contexto rionegrino atual, de baixa pressão colonizatória, a dinâmica interna das relações comunais redimensionou seu papel, designando-os para atuar principalmente na ordenação da vida cotidiana das povoaçọ̃es e no contato com membros da sociedade nacional que a elas acorram. O capitão permanece como figura de referência no contato com os não-índios, mas tal atividade não se traduz em arregimentação de mão-de-obra ou em captação/ acumulação diferenciada de bens, em relação aos demais; a mediação de negociações com parlamentares, com a Prefeitura, e outros órgãos do poder público ainda é feita por eles, mas vem sendo paulatinamente suplantada pela atuação das Organizações de Base. 
A interlocução dos capitães com autoridades não-indígenas expressa em grande medida um padrão clientelista que foi dominante no regime do barracão extrativista e ainda costuma ordenar a busca por bens e serviços pelas populações pauperizadas da Amazônia, a qual costuma ser viabilizada mediante relações verticais, tipo patronal-clientelista, que continuam em vigor e produzindo relações de dependência.

É flagrante a diferença entre as práticas discursivas das jovens lideranças indígenas que reivindicam direitos legais e as dos capitães, particularmente os mais idosos, que, através do que é chamado localmente de 'discurso de coitado', tentam driblar a profunda assimetria das interações com o poder político e econômico local.

Nós, lideranças, não queremos pedir coisas, nós queremos é mandar alguém fazer o que é de direito; pra fazer coisas tem o governo; ele é que tem que fazer e nấo faz, por isso a liderança tem que cobrar que ele faça... O problema dos capitães é que eles ficam sozinhos para enfrentar os brancos, é difícil, dá medo; por isso é que eles, quando querem conseguir as coisas, dizem que nós somos uns pobres coitados, que não sabemos nada, que não temos nada; eles não se valorizam, não valorizam o indígena, mas é o jeito deles; ficam fazendo dessa maneira, se fazendo de bom ou de coitado para conseguir alguma coisa, porque nâo sabem dos nossos direitos. (I. B., liderança evangélica koteroenı)

A aliança com as Organizações de Base costuma ser benéfica para as chefias de aldeia, pois, no contexto baniwa atual, elas representam um veículo privilegiado de captação de benefícios sociais, bens industrializados e geração de renda, cuja circulação nas aldeias é realizada a partir de pressões de capitães em busca da manutenção de seu prestígio e das obrigações redistributivas típicas dos circuitos de reciprocidade.

As atividades do capitão foram sendo redimensionadas ao longo do processo histórico de contato, mas uma de suas antigas atribuições, a recepção dos visitantes, permaneceu intocada. Nos dias de hoje, porém, o trabalho na aldeia e a movimentação de visitantes, notadamente não-indígenas, aumentou muito, exigindo do capitão um dispêndio de tempo e esforço outrora desconhecidos; é o que se pode observar no depoimento a seguir:

O que eu escuto muito é que quem lidera hoje em dia uma comunidade tem muito trabalho, são coisas que antigamente não tinha; hoje o capitão tem que lidar com prefeito, com pessoal de secretaria, com muitos brancos que passam, muitos visitantes que vêm de fora. Mesmo quando você tem Conferência e vem muita gente, é mais fácil, porque são os parentes e já é da convivência; o problema são os que vêm de fora e as reuniões que o capitão tem que ir, tem que viajar pra São Gabriel, coisas assim. Ainda tem que ver o motor de luz 
que quebra, ver conserto na casa comunitária, vem vacina, é muita coisa! Antigamente não tinha isso, hoje isso dá muito trabalho e o capitão não tem tempo pra sua roça, pra sua família, gasta todo tempo nisso, daí o máximo que ele agüenta é dois, três anos, daí ele sai porque senão a família dele fica muito prejudicada. Antigamente, o capitão era capitão e só tinha que se preocupar em receber os parentes mesmo, fazer certas festas e as coisas do dia-a-dia da comunidade. Assim, dava pra ele ter a vida normal dele de fazer roça, fazer canoa, caçar, pescar para a família. Isso é o que eu escuto as pessoas falarem, por isso elas inventaram isso de ter mandato de no máximo quatro anos, pra dar tempo pra pessoa trabalhar para sua família. (R. G., vice-capitão evangélico Adzanent)

O estabelecimento de eleições e mandatos para o capitão ainda é uma coisa nova na região. Alguns informantes mais velhos são taxativos em condenar a novidade, atribuindo-a à 'mania de imitar os brancos'. Nas comunidades com um pequeno número de famílias, prevalece o antigo sistema: o capitão costuma ser o membro mais velho da família também classificada como mais velha em relação a outras ali residentes; com o passar dos anos, por morte ou idade avançada, surge a necessidade de substituí-lo. Nessas ocasiões, a escolha costuma recair sobre um de seus filhos, desde que tenha idade e comportamento considerados adequados ao cargo. Na ausência de um candidato que obedeça a esses requisitos, a escolha é direcionada para a família seguinte em ordem de senioridade, e assim por diante. Nas comunidades maiores e/ou sob maior influência do contato interétnico é que se observa o estabelecimento sistemático do processo eletivo para a escolha do capitão, com um mandato que costuma ter duração de quatro anos.

A eleição é uma ressignificação das regras eleitorais tal como as conhecemos. Os dados obtidos mostram que não é qualquer pessoa que goza de credibilidade suficiente para se candidatar e ter a chance de ser eleita; só os membros de alguns sibs, aqueles identificados como sibs de prestígio e de chefia, têm chances reais de obter sucesso em um processo eletivo. A rotatividade do cargo de capitão é, portanto, uma mescla entre um processo eleitoral direto e a hierarquia dos sibs, congregando apenas candidatos oriundos de alguns nichos do corpo social. Embora o indivíduo eleito possa ser substituído a cada quatro anos, os membros de um mesmo sib costumam manter o controle do posto; não é infreqüente que a ocupação do cargo circule entre pai/filho-mais-velho/filhodo-meio/filho-mais-novo de uma mesma família que se revezam no papel de capitão a cada quatro anos. Em outras situações, a eleição de um genro ou cunhado pode representar uma compensação por sua permanência na aldeia da esposa, renunciando ao privilégio da patrilocalidade. ${ }^{68}$ 
Sobre o tema, diz uma liderança:

... tem mandato, mas nấ é todo mundo que concorre; essas pessoas de clã baixo nem querem competir porque ele acha que não é papel deles, porque não é ele quem tem que estar lá, na frente; mas se quiser também, dificilmente vai ser eleito. Tem eleição, mas só quem concorre são aquelas pessoas de família de clã alto. É misturado, tem eleição, tipo de branco, mas só quem concorre na eleição são as pessoas daquelas famílias de clã de chefe. (P. J., liderança walipere dakenal)

Numa comunidade grande, é comum a presença de famílias consideradas 'de fora', isto é, que vieram de outras aldeias, muitas vezes várias gerações atrás; estas, porém, não costumam ter boas oportunidades na participação em processos eleitorais. No geral, a tendência destes 'estrangeiros' é evitar uma disputa na qual suas chances são reduzidas e sempre existe o risco de uma confrontação direta com outros concorrentes que se sentem como candidatos mais legítimos, mais ligados à família que fundou a aldeia, os chamados 'donos da comunidade'.

O processo de transformação histórica do papel da chefia de aldeia é assim descrito por um informante:

É, dentro dos Baniwa é assim, mas isso é já adaptando uma própria imposição dos missionários; eles diziam: "tem que ter capitão, tem que ter liderança". Na verdade sempre teve, mas era diferente. Antigamente, o líder era escolhido de uma descendência pra outra; ele era escolhido já com uma certa idade, com uma certa experiência de vida, ele era escolhido assim, depois de ser bem observado por todos. Aí, ele entrava para ser líder e só saía depois que estivesse muito velho ou depois de morrer; essa era a maneira tradicional, ele vinha de família de líder; para ser líder de uma comunidade era escolhido talvez já na faixa de 40 pra 50 anos, e depois que a pessoa tivesse mostrado um comportamento bom na convivência com todos. Já nesses tempos de hoje, o que eles fazem é geralmente isso; hoje tem capitão, vice-capitão, secretário e animador; são quatro pessoas que dirigem uma comunidade. Além disso, nos crentes tem o ancião, que é, hoje, a pessoa que faz o papel tradicional, porque ele entra e não sai; ele sempre vai dar conselho, vai apartar um do outro, aconselhar pra não fazer coisa errada. Eu acho que esse é o papel mais tradicional, porque ele entra naquela vida e só sai quando estiver muito velho ou quando morrer. Já o papel do capitão é mais pra confrontar com a vida política atual, com os brancos, com a Organização, com os políticos. Por isso que, quando erra, isso acaba causando briga, por causa de certos benefícios que são recebidos e não são divididos. Quando está tendo um desentendimento, se ele for entre as lideranças que estão na frente, se elas é que estiverem tendo essa briga, sai tudo, não pode ficar. Se a briga for com um membro da comunidade, aí a liderança tem que conversar pra ver se pode acabar a briga. (R.. F., liderança evangélica, walipere dakenai) 
A mudança das condições históricas, levando a uma intensificação das relações com espaços não-indígenas de poder também tem aumentado a necessidade de competência lingüística do idioma português. Para um exercício adequado de suas funções, hoje também se exige dos chefes de aldeia o manejo de um conjunto mínimo de informações sobre as formas de operar do mundo e instituições dos brancos, das regras de etiqueta que envolvem as interações entre essas realidades, de conhecimentos técnicos sobre os equipamentos de uso comunal, como os motores de popa e geradores de luz; enfim, um grande conjunto de saberes que os habilitem para o desempenho satisfatório de suas funções. Trata-se de uma ampliação das atribuições de recepção de visitantes, de negociação com elementos da alteridade - que nos dias de hoje também é constituída de falantes de português - e de gerenciamento do cotidiano da aldeia. Tais demandas podem favorecer a eleição de capitães mais jovens e mais escolarizados, sem que ocorra uma alteração profunda nas esferas decisórias da aldeia. Como enfatiza o relato que reproduzimos anteriormente, o capitão não é a única instância de poder na aldeia; decisões difíceis e controvertidas costumam ser tomadas mediante a consulta aos membros mais velhos da comunidade; face ao seu nulo poder de mando, ele necessita da adesão de membros influentes do grupo às suas idéias e propostas, para viabilizar a condução dos assuntos da vida diária da comunidade.

Igualmente, a atuação da liderança de Organização tem como exigência básica o conhecimento de habilidades próprias do mundo do branco e de suas relações de poder. $\mathrm{O}$ aprendizado de técnicas e da linguagem institucional, como abaixo-assinados, ofícios, requerimentos, formulários, estatísticas, procedimentos administrativos e elaboração de projetos, para captação de recursos e prestação de contas, são pré-requisitos comuns ao militante do movimento indígena, ao professor e ao agente de saúde. A posse desses bens simbólicos viabiliza, dentro de certos limites, a contestação da hierarquia de gerações, mas tal possibilidade não deve ser absolutizada, pois, como se viu, os critérios de legitimação são múltiplos e a escolaridade representa apenas uma pequena fração de um conjunto mais amplo de requisitos.

A transformação das lideranças em 'cidadãos do mundo' passa também pela adoção de práticas sociais e políticas modernas e pela ressignificação das disputas e padrões de comportamento dos grupos de parentesco a que pertencem. Essas entidades funcionam nos moldes da sociedade nacional, mas também traduzem as relações travadas entre grupos hierarquizados de parentes. Em função disso, seus dirigentes precisam gerenciar a coexistência entre os padrões de organização política da modernidade - fundada nos direitos de cidadania, no voto, no igualitarismo entre os representantes - e o exercício do poder do parentesco, que lhes outorga o papel de mediador entre sociedade nacional e mundial, mas não abandona o controle de seu desempenho. 
Tais variáveis estabelecem campos de interações conflitivas e negociações estabelecidas entre dois principais tipos de capital cultural ${ }^{69}$ que ali disputam sentidos: o dos saberes míticos dos xamãs, donos de cânticos e outros membros idosos da sociedade e o saber escolar e técnico-administrativo detido pelas gerações mais jovens. A distância entre as formas de operar dos dois tipos de capital simbólico dificulta o entendimento dos modos de funcionamento das Organizações e o controle de seu trabalho pelos mais velhos. Ainda assim, a parca informação detida por eles não inibe suas expectativas sobre o desempenho das lideranças que negociam com o mundo dos brancos, particularmente no que diz respeito às tarefas de captar e distribuir bens industrializados, canalizados através do trabalho da Organização.

Uma vez que a realidade opera como um sistema multidimensional, a posição momentaneamente ocupada pelo agente político varia no tempo, ora ocupando um espaço mais central de poder, ora um lugar periférico, sem que haja uma garantia de manutenção permanente da posição hegemônica por nenhum dos atores sociais em pauta. Apesar da proeminência dos saberes obtidos no mundo do branco, os líderes que rompem com as expectativas de seus liderados podem ter sua representatividade sumariamente bloqueada, ao lhes ser negado novo acesso à representação de seu grupo de parentes em cargos eletivos do movimento indígena.

O trabalho político cotidiano exige o entendimento do mundo nãoindígena, da dinâmica do próprio movimento e das conjunturas políticas e econômicas que possam favorecer ou dificultar as lutas étnicas. Nas aldeias, há uma circulação limitada destas informações, boa parte das quais exige o domínio da escrita, o que deixa muitos líderes potenciais fora do páreo e aprofunda a assimetria. Entre as próprias lideranças indígenas a apropriação desses saberes é desigual; tanto podemos encontrar lideranças perfeitamente familiarizadas com a linguagem do mundo globalizado, como outras que, em fase mais inicial de aprendizado, expressam posições mais próximas às do mundo da aldeia, imersas numa lógica predominantemente local.

Nas Organizações Indígenas observa-se um padrão de aprendizado horizontal, informal, desenvolvido no contato das lideranças entre si, numa forma eminentemente social de apropriação de saberes. O locus de aprendizado são as práticas regionais, nacionais e internacionais do movimento, pelas quais os dirigentes aprendem a lidar com eventos, reuniōes, audiências com autoridades, a elaborar projetos e negociar credibilidade com suas bases e com as outras entidades, buscando ampliar a legitimidade, o prestígio, os recursos e bens captados no trabalho político. Tais estratégias de ação e de aprendizado, características do movimento indígena, geram construções analíticas específicas, distintas daquelas praticadas por instituições não-indígenas que exercem funções sociais similares e que forneceram o modelo político e administrativo inicial que orientou a constituição do movimento indígena no Brasil. A aquisição horizontal desses saberes redunda 
na acumulação de um capital cultural essencial para o desempenho de papéis e atribuições na política indígena (Bourdieu, 1989).

O campo político produzido na interface do contato interétnico exige um progressivo aprofundamento dos registros escritos, implicando uma separação entre os processos de produção e transmissão de conhecimentos e uma dinâmica educativa distinta das formas de cognição e reflexão pré-contato, nas quais não há uma dissociação entre os momentos de transmissão, aprendizagem, composição/ recriação de saberes que se dão pela oralidade, diluídos na vida cotidiana. $O$ pensamento domesticado pela escrita é utilizado pelas lideranças no trabalho de gestão de suas entidades, e as que têm poucos anos de estudo enfrentam muitas dificuldades para produzir a documentação necessária, que compreende um amplo leque de relatórios, regimentos, planejamentos, movimentação bancária etc.

A apropriação de conhecimentos oriundos das relações de contato exige não apenas o domínio ágil da linguagem formal-institucional, mas também o aprofundamento nos campos especializados da saúde, da educação, do direito e da política, com o manejo de temas como princípios universais de justiça e de igualdade de cidadãos, direitos humanos, democracia, voto e direitos de cidadania. O cardápio básico do trabalho da liderança inclui categorias como a de reivindicação, herdada do código jurídico ocidental, que se constitui numa das principais estratégias de lutas étnicas. O líder deve apreender, manipular e ressignificar tais conceitos, passando a utilizá-los num contexto diferente daquele de sua cultura de origem e também da sociedade que o gerou. Ante a crônica ausência de cumprimento de suas funções pelos ocupantes do poder, busca-se a geração de estratégias que possam suprir alternativamente o trabalho que os governantes deixaram de fazer.

A existência de demandas reprimidas nas áreas de saúde, da autosustentação e da educação costuma gerar fortes pressões, por parte dos capitães, para que o movimento indígena encontre formas de atendê-las. Caso a Organização tenha sucesso, sua atuação resulta na ampliação do poderio das chefias de aldeia; se estes anteriormente tentavam responder a tais questões por meio de um 'corpo a corpo' com as autoridades, atualmente preferem encaminhar tais demandas para as suas Organizações de Base.

\section{No Campo Sanitário...}

A implantação do Distrito Sanitário Especial Indígena surge dentro da área baniwa na forma de uma inédita prestação de cuidados de saúde oferecidos nas próprias aldeias, propiciando ainda a participação indígena em conselhos de saúde nos quais se planeja e se delibera, de forma paritária, sobre as atividades programadas. 
Garnelo (2001) e Garnelo \& Wright (2001) demonstraram que as demandas baniwa por cuidados biomédicos são configuradas pelas representações e práticas tribais de conservação da saúde e prevenção de doenças. Não se constituindo em campo autônomo, a questão sanitária é sempre referida à cosmologia do grupo e às relações de poder intra e interétnico; desta forma as categorias baniwa de doença fornecem um campo de 'ancoragem' para a apropriação dos saberes biomédicos circulantes nas aldeias. Do conjunto de informações disponibilizadas pelo discurso autorizado da saúde, apenas alguns elementos são selecionados, em geral aquilo que pode subsidiar e legitimar as práticas e demandas políticas e sociais dos indígenas e que, com freqüência, passam ao largo dos desígnios e prioridades das agências de saúde.

As explicações biomédicas costumam ser aproveitadas quando apresentam congruência com os saberes preexistentes e/ou quando se coadunam com as necessidades determinadas pelas condições de vida. Este aproveitamento passa, porém, por um processo de ressignificação que redimensiona seus sentidos prévios, configurando-as como novas realidades sociais, capazes de orientar as relações travadas no âmbito da vida cotidiana, contribuindo para legitimar e/ou redimensionar a identidade indígena e prover mecanismos de entendimento da realidade prévia e dos novos saberes circulantes no meio social. A apropriação (e a expressão) dos conceitos sanitários não é nem individual, nem arbitrária, mas demonstra a existência de um mercado simbólico no qual coexistem distintos modelos de saúde, indígenas e não-indígenas. Dentre os últimos, destacamos o campanhismo praticado pela Funai por intermédio de suas Equipes Volantes de Saúde (EVS); o higienismo moralizante praticado pelos missionários, um conjunto heteróclito de informações de senso comum próximas ao que se denomina de medicina popular; o discurso da medicina curativa de 'alta densidade tecnológica' e a presença ainda tênue do sanitarismo preventivo do Distrito Sanitário.

Tanto lá como aqui, o modelo médico curativo é hegemônico, mas sua apropriação pelos Baniwa não equivale a uma simples reprodução das práticas sanitárias vigentes nas instituições biomédicas. Na sociedade baniwa, as práticas sanitárias costumam assumir o formato das regras do bom convívio social e de circulação de mercadorias, sendo objetivadas em produtos, como remédios, exames e combustível. Quando os informantes reivindicam atendimento curativo aos doentes, eles esperam que não apenas as pessoas enfermas sejam tratadas, mas também os seus consangüíneos, expectativa que está em consonância com a prestação nativa de cuidados. Gera-se igualmente a expectativa de que as equipes de saúde cumpram as regras do bom viver, que incluem a partilha de alimentos, a troca de gentilezas e informações com as lideranças locais, os ritos de higiene corporal, enfim as atitudes que caracterizam as regras de comportamento socialmente adequado para os membros desta cultura. Para os usuários baniwa 
dos serviços distritais, os profissionais de saúde deveriam inserir combustível e medicamentos no circuito de troca de presentes, distribuindo-os com generosidade (Garnelo, 2001).

A lógica subjacente aos cuidados de saúde também influencia as formas de uso de medicamentos industrializados; por exemplo, um conhecedor de plantas é socialmente prestigiado quando conhece um grande número delas e é capaz de preparar receitas complexas, que, por vezes, exigem o concurso de várias plantas; de forma análoga, um bom agente de saúde deve conhecer um grande número de medicamentos. Para os agentes de saúde e demais pessoas nas aldeias, o medicamento é o símbolo essencial do saber/poder em saúde; apesar de os agentes serem perfeitamente capazes de desenvolver atividades como preparo de soro caseiro, controle da desnutrição, educação em saúde e imunização, nenhuma dessas ações confere o prestígio obtido com o domínio dos medicamentos industrializados dos brancos. ${ }^{70}$

Também existe uma relação de analogia entre os instrumentos de trabalho do xamã e os do agente de saúde, considerado como conhecedor/doador de remédios (ithapetakaita). Se um xamã é impotente para curar sem os seus instrumentos mágicos (maracá, pedras, cigarro etc.), também o agente de saúde precisa do medicamento para materializar o poder mágico obtido na alteridade. A demanda reprimida dos medicamentos não fornecidos pelas instituições de saúde tem sido suprida por intermédio da obtenção alternativa com parentes, políticos, garimpeiros, pelotões do exército ou mesmo através da compra nas farmácias na cidade. Apesar da oposição dos profissionais não-indígenas de saúde, os medicamentos se inseriram e hoje são importantes componentes do circuito de trocas generalizadas.

O processo de Distritalização na área baniwa gerou um infindável leque de discussões e explicações sobre a sua natureza, finalidades e formas de organização; apesar disso a apreensão do conceito de Distrito Sanitário se dá essencialmente pelo seu aspecto material, como se pode ver nos dois depoimentos a seguir:

...pra mim o Distrito é uma coisa que se chama pólo-base, onde vai colocar essa casa, né? É prédio, uma casa pequena mas vai ter rádio, microscópio, motor e uma equipe completa que vai trabalhar; eles vão demorar aqui, assim um mês e depois retorna pra lá; depois vem outra equipe pra trabalhar também. Assim que é o pólo-base do distrito. (G. G., capitão mawlienı)

...esse Distrito Sanitário Especial Indígena é uma casa completa, equipada: tem radiofonia, tem motor, enfermeiro, auxiliar de enfermagem, médico, dentista e agente de saúde no meio deles; vai ser treinado tudo junto; isso é o Distrito Sanitário. Porque muitas dessas pessoas vêm pra ajudar no melhoramento da nossa vida, no futuro, sabe? Não sei se vai funcionar tudo 
isso, mas graças a Deus vamos esperar isso, né? Esse Distrito Sanitário, se ele funcionar aqui no meio de nós, indígenas, ele vai facilitar o nosso trabalho porque, por enquanto, nós estamos sofrendo. Se, por exemplo, ele vai implantar pólo-base com rádio aqui no Canadá, vai ficar mais fácil pra nós trabalhar; se ele funcionar já, vai ter auxiliar de enfermagem, um médico, fazendo viagem nas comunidades, ao menos uma ou duas por ano vai ser bom. Isso é que é Distrito Sanitário. (I. S., agente de saúde walipere dakenal)

Apesar de enunciados por agentes sociais distintos e em contextos muito diferentes, os depoimentos são bastante parecidos, o que pode ser atribuído ao esforço das Organizações Indígenas para disseminar as idéias da distritalização. As falas destacam duas reivindicações essenciais para os Baniwa: uma base material comportando pessoas e equipamentos, configurando o distrito pela presença física de equipes, prédios e materiais. O outro ponto importante é a permanência dos profissionais nas aldeias; uma das maiores reclamações em todo Alto Rio Negro é que as equipes de saúde permanecem pouco tempo nas comunidades quando para lá se deslocam a serviço; o que é interpretado como manifestação de etnocentrismo, de rejeição à convivência com os indígenas.

As ações sanitárias atribuídas ao Distrito são visivelmente influenciadas pelo modelo campanhista de cuidados de saúde, historicamente praticado pela missão salesiana e pela Funai, caracterizado pelo deslocamento periódico de profissionais para as aldeias, realizando atendimentos curativos de baixa resolutividade, centrados na demanda espontânea da população. Tanto nas reivindicações espontaneamente levadas aos conselhos de saúde quanto nos depoimentos gravados para a pesquisa, observou-se um escasso grau de penetração das propostas sociopolíticas e preventivas contidas no modelo de cuidados primários de saúde que orientam a distritalização sanitária veiculada pela Funasa.

A implantação dos conselhos locais de saúde no Içana e Aiari possibilitou a ampliação de espaços de reivindicação antes situados apenas na distante São Gabriel. As reivindicações encaminhadas e esses conselhos evidenciam os peculiares caminhos do pensamento sanitário baniwa. Por exemplo, as solicitações de aumento do número de agentes de saúde são antigas e foram parcialmente viabilizadas pela distritalização. A análise dessas demandas mostra que elas obedecem mais às prioridades comunais do que a necessidades de saúde. A presença de um agente de saúde representa não apenas prestígio perante outras aldeias, mas viabiliza também o ingresso dos cobiçados bens que acompanham sua atuação, além do pagamento de salário regular a ele.

As aldeias que não dispõem desse profissional indígena são atendidas por um que more mais próximo, uma medida centrada na racionalidade técnicoadministrativa dos serviços de saúde, que trabalham segundo a noção de área de abrangência de serviços e profissionais, mas que fere o ideal autárquico das aldeias 
e que costuma exacerbar conflitos preexistentes. Longe de ser um ato técnico, a contratação de agentes tem um caráter intensamente político, que pode ampliar ou minar o prestígio da Organização Indígena e dos representantes indígenas nos conselhos, em geral os encarregados de negociar estes privilégios com o sistema de saúde.

Desde 1998, os agentes de saúde do Alto Rio Negro foram contratados pela Foirn, por meio de recursos obtidos em convênio firmado com a Funasa, passando a receber um salário mensal por seu trabalho. $\mathrm{O}$ assalariamento representa um importante ingresso de recursos em uma vida social marcada pelo baixo nível de acesso à economia de mercado; em conseqüência disso, os membros de sua parentela têm exercido uma pressão permanente para inserir estes ganhos no circuito coletivo da partilha de bens, cobrando dos agentes uma redistribuição de seu salário por meio da compra de itens como sal, pilhas, sabão e roupas, que, embora sejam gêneros de primeira necessidade, são de difícil aquisição pelos aldeados.

Os profissionais indígenas de saúde têm reagido contra esta forma de apropriação coletiva de seu salário e em algumas localidades encontramos capitães dispostos a depô-los e assumir o seu lugar, pois querem receber seu ganho; outros iniciaram um movimento coletivo pelo qual vêm pleiteando uma remuneração pela realização de suas atividades perante as comunidades. Os agentes não têm sido bem-sucedidos em convencer a parentela do direito de apropriação individual da remuneração obtida por seu trabalho e alguns tentam conciliar o conflito, oferecendo presentes baratos (sabão, bombons, fósforo) para os co-residentes. $\mathrm{O}$ assalariamento do agente de saúde é visto por muitos velhos como um privilégio indevido, que contribui para subverter a hierarquia de gerações, o que vem desencadeando pesadas formas de controle da individualização que ele pode potencializar.

No momento em que assume uma condição regida por saberes técnicos e beneficiada por um ganho regular, o profissional indígena passa a ocupar um status não partilhado por outras pessoas da comunidade, acionando as já conhecidas estratégias de controle da diferença, típicas das sociedades rionegrinas. Ele se torna alvo de boatos, o temor do Manhene se exacerba, suas ações são fiscalizadas, seus movimentos controlados, sua presença na aldeia é cobrada e se instala um maior rigor na avaliação da conduta de um detentor de bens e prestígio que estão fora do alcance de seus co-residentes.

Seus deslocamentos para fora da aldeia são freqüentes e se devem principalmente ao paralelismo da ação institucional e à desconsideração com o ritmo de vida comunal, acirrando os conflitos já instalados. Nos anos de 1999 e 2000, os agentes de saúde baniwa tiveram de se deslocar de suas comunidades para um comparecimento obrigatório a cinco eventos por ano em São Gabriel da Cachoeira, organizados por diferentes instituições de saúde, o que acarretou um 
longo período de afastamento de casa. Neste sentido, o comportamento das equipes de saúde é bastante etnocêntrico, por desconsiderar as condições de vida do agente e gerar múltiplas demandas que conflitam com as atividades rotineiras nas aldeias, seja o próprio trabalho de saúde ou aqueles voltados para a sobrevivência de sua família, como a pesca e a roça.

$\mathrm{O}$ desenvolvimento de atividades de planejamento participativo nos conselhos de saúde possibilitou a muitos agentes, que são também conselheiros, o acesso às planilhas de custo das ações programadas, onde estão registrados os salários a serem pagos às outras categorias profissionais (médicos, enfermeiros, e técnicos de enfermagem e de laboratório), dando-lhes uma medida da disparidade salarial existente entre profissionais indígenas e não-indígenas. ${ }^{71} \mathrm{O}$ quadro se agravou quando os agentes puderam comparar o salário mínimo que recebem com a remuneração dos Técnicos de Enfermagem, boa parte dos quais são indígenas que recém-concluíram o $2^{2}$ Grau em São Gabriel, cujo salário é de aproximadamente $\mathrm{R} \$ 600,00$. A constatação da assimetria gerou um clima de irritação entre os agentes indígenas, particularmente os mais antigos, que passaram a pleitear em sua associação um aumento de salário diferenciado segundo os anos de experiência e trabalho nas aldeias.

Em seu ponto de vista, os recém-chegados, independente da categoria profissional, deveriam receber salários menores que os dos profissionais mais antigos. Tal reivindicação obedece a critérios distintos daqueles fundados na escolaridade e qualificação técnica; ela se baseia na mesma lógica que leva os capitães a cobiçarem o salário do agente de saúde: quando comparados aos mais jovens/menos experientes, os mais velhos/mais experientes devem ter acesso preferencial aos bens e privilégios outorgados pela sociedade.

As representações sociais e demandas baniwa pelos cuidados de saúde no Distrito Sanitário se processam através de temas e prioridades muito distintas das discussões sobre terceiro setor, neoliberalismo e papel do Estado no desenvolvimento de políticas sociais, que vêm ocupando o cenário político das grandes Organizações Indígenas. A lacuna entre as duas realidades desnuda um processo de negociação política, ora forjada no espaço interfrátrico, ora no campo interétnico, no qual os atores sociais disputam posições e privilégios na cena social formada pelos conselhos de saúde; para esta finalidade, lançam mão de produções discursivas permeadas pelo recém-incorporado discurso sanitário que emerge do processo de distritalização, mas que são manejadas pelos agentes políticos também como ferramentas não sanitárias, voltadas para o atendimento de demandas e prioridades das relações de parentesco.

A lógica do pensamento indígena redimensiona as distinções e regulamentações monopolizadas pelo sistema de saúde, que habitualmente define o que sejam demandas sanitárias legítimas, borrando as distinções institucionais 
entre público e privado. Nesta ótica, a definição de prioridades nos conselhos de saúde tende a atender mais a necessidades dos grupos familiares do que a prioridades técnicas genéricas, como a redução de doenças preveníveis obtida pela vacinação dirigida, por exemplo, a grupos de adversários. As reivindicações e avaliações indígenas do processo de distritalização passam por critérios distintos de racionalidade epidemiológica, que avalia o impacto das ações de saúde pela melhoria do perfil mórbido da população. A visão indígena de mundo prioriza fatores como a presença física de profissionais, contato personalizado destes com a clientela indígena e a fartura na distribuição dos insumos de saúde que ocupam um lugar privilegiado na hierarquia rionegrina de valores e que 'deixam as pessoas contentes' com a passagem das equipes.

66 Segundo a conceituação de Bourdieu (1989, 1996a, 1996b), o capital simbólico representa o reconhecimento e a legitimação num meio social de uma acumulação de bens materiais e culturais por indivíduos ou grupos pertencentes a este conjunto social, capaz de lhes conferir condições sociais de êxito em intervenções concretas no cenário social; trata-se do poder socialmente reconhecido de impor uma certa visão de mundo, em concorrência com outras potencialmente válidas.

67 Ao falarmos em relação de trocas com o aviador, não se está negando a assimetria e a violência que permeavam estas interaçōes; queremos apenas enfatizar um lado pouco explorado, o dos interesses indígenas envolvidos nesta interação. Por mais assimétricas e coercitivas que fossem as relações do sistema extrativista, a partir do ponto de vista nativo o que se estabelecia era um tipo de relação de troca, tensa, desconfiada, travada nas perigosas fronteiras da alteridade, mas congruente com as sangrentas lutas travadas por Nhiãpirikolie seus consangüíneos para obtenção de bens materiais e simbólicos que constituíram a cultura baniwa. A manutenção das relações extrativistas gerava/mantinha poderes e privilégios locais, se constituindo como transações materiais colocadas a serviço das relações sociais travadas localmente.

68 Esse padrão talvez seja uma especificidade da área baniwa, pois outros entrevistados da etnia Baré atribuem o advento de eleições para capitão nas comunidades que se formaram no Baixo Rio Negro - a partir de uma aglutinação gerada em torno de escolas rurais implantadas pelos salesianos - ao seu caráter multiétnico, o que gerava uma intensa disputa de poder entre seus moradores; neste contexto a eleição representava uma tentativa de apaziguar conflitos.

69 Capital cultural pode ser representado pela acumulação de bens não-materiais como saberes, habilidades técnicas, domínio de linguagens e outros meios que facilitam a intervenção e a busca de posições hegemônicas no meio social (Bourdieu, 1989).

70 O poder mágico dos brancos é um elemento presente em muitos mitos baniwa, assim como a caracterização de patologias como a 'Praga', doença grave, freqüentemente de evolução fatal, 
gerada pela ação de macumbeiro branco. As mercadorias oriundas do mundo dos brancos são consideradas como fonte de poder mágico, passíveis também de gerar doenças. O medicamento industrializado é considerado parte deste poder; ao aprender seu manejo, o agente de saúde passa a partilhar dessa magia, que pode ser utilizada para a cura de doentes. Nessa ótica, a ação farmacológica não é considerada como elemento essencial na cura.

71 As cifras são realmente muito díspares; o salário para os médicos é da ordem de $\mathrm{R} \$ 7.000,00$, quarenta vezes maior que a remuneração dos agentes, fixada em $R$ \$180,00; ambos os valores aqui referidos são brutos, incidindo sobre eles os descontos de ISS e INSS, o que reduz ainda mais o ganho proporcional do agente de saúde. 
A discussão até aqui desenvolvida pretendia identificar meios nativos de apropriação de sua cultura ancestral e dos novos elementos trazidos pelo contato interétnico, apreender as interações sociopolíticas, culturais e cognitivas travadas no Alto Rio Negro e compreender como agentes etnopolíticos - tomados como manifestações individuais de experiências coletivas - atuam na definição, reprodução e transformação das relações de força e assimetrias que perpassam suas vidas. Buscou-se igualmente demonstrar como os aspectos internos da cultura baniwa estão sendo historicamente reordenados e como a reprodução de sua estrutura vem gestando a transformação de si própria e estabelecendo um 'modo baniwa' de interagir com o mundo não-indígena.

A exploração das concepções tradicionais de doença e cura evidenciou sua condição de elemento multifuncional que engloba diversos tipos de relações econômicas, morais, políticas e técnicas, que fazem delas 'fatos sociais totais', pelos quais se pretende preservar a ordem social vigente, sem nunca lográ-lo plenamente. Os eventos patológicos ligam-se diretamente à dimensão relacional da existência, razão pela qual os cuidados com a saúde são concebidos como mediadores materiais e simbólicos destinados a reduzir a anomalia gerada pela eclosão do episódio mórbido e a reconduzir o doente aos comportamentos desejáveis a uma plena condição humana.

Doença, cura e cuidados de saúde têm íntimas interações com as formas autóctones do controle exercido sobre os membros de uma sociedade, na qual a produção e a modulação da doença são expressões da política e da ética do grupo; sua ocorrência é indicativa de conflitos cósmico-sociais, não se esgotando na problemática particular do indivíduo doente. Categorias como likoada e manhene permitem entrever os caminhos através dos quais o político perpassa o campo sanitário baniwa e como influenciam na moldagem das novas práticas políticosanitárias exigidas por sua inserção no mundo globalizado. Sendo estratégias produzidas segundo a lógica ancestral da cosmologia do grupo, também se configuram como formas de ação simultaneamente sanitárias, sociais, morais e educativas, oferecendo parâmetros para avaliação do desempenho das lideranças 
etnopolíticas e base para a incorporação dos saberes biomédicos, veiculados a partir das relações interétnicas.

Os cuidados pela preservação e recuperação da saúde também estabelecem conexões entre a vida cotidiana e os fundamentos mítico-rituais, repercutindo nos mais diversos planos da vida social. A plena retomada da condição de membro adulto do grupo por um doente implica a revitalização de relações de solidariedade, reciprocidade, limitação dos comportamentos excessivos de toda ordem, e cultivo da sobriedade. Não por coincidência são requisitos similares àqueles exigidos para um bom desempenho da chefia, formando a base da vida pública e atestando a disposição para a harmonia e a restrição à expressão aberta de conflitos.

Saberes sobre doença e cura são uma alternativa para propiciar o controle de uma fração do corpo social - aqui representada pelas gerações mais velhas sobre outra desprovida dos meios rituais necessários para garantir a reprodução da sociedade. É um tipo de poder simbólico, mas não desprovido da capacidade de gerar mudanças concretas na vida social, transformando produções mentais em relações sociais e garantindo a hierarquia que fundamenta a ordem social.

No mundo baniwa a hegemonia das gerações que detêm o controle dos meios simbólicos de reprodução social vem sendo ameaçada pela eclosão de outras formas de poder obtido no mundo não-indígena, acirrando tensões preexistentes no interior da sociedade. Num grupo em que a alteridade tradicionalmente tem sido considerada como fonte de poder e de transformação, tais situações não são inusitadas; a rebeldia dos jovens ocupa um lugar central em sua cosmogonia, sendo um comportamento previsível, que conta com estratégias que visam sua normalização. O que gera a singularidade do momento atual da vida desse povo é a ampliação da capacidade contestatória dos jovens pelo movimento etnopolítico, cujas conquistas materiais se mostram potencialmente capazes de superar ou neutralizar o poder simbólico dos mais velhos e acelerar as transformações na tradição do grupo. Nessa ótica, a medida de sucesso do movimento indígena pode ser a própria medida de mudança - eventualmente indesejável - de uma ordem social calcada no controle dos mais jovens e na negação da individualidade.

Antigas noções de chefatura, guerra, hierarquia de sibs e de gerações também permanecem ativas e operantes desempenhando funções éticas e normalizadoras. Elementos centrais na cosmologia baniwa, aparentemente restritos àquilo que se convencionou chamar de tradicional, os venenos manhene, os sopros, a hierarquia de sibs e as obrigações de reciprocidade agrupadas sob a idéia de likoada tanto intervêm no campo sanitário, quanto configuram as relações intercomunais e as ações das entidades de base, atribuindo sentidos inusitados a atividades desenvolvidas em contextos interétnicos como as assembléias da Foirn e as eleições de líderes e chefias de aldeia. A recente revitalização das hierarquias, em resposta a novas demandas, demonstra que a estrutura de parentesco permanece 
regulando a definição e redefinição dos espaços e lugares dos atores políticos, obrigando-os a desenvolver esforços extraordinários caso se arrisquem a romper os limites definidos pela ordem vigente.

A reciprocidade, base das relações cósmicas e sociais, perpassa os diversos níveis da vida social aqui mencionados. A troca de favores, a partilha de bens, a afabilidade com os membros do grupo garantem a contrapartida de atitudes similares. Os comportamentos destrutivos e agressivos implicam igualmente retorno do mesmo teor. Tal condição modela as expectativas comunais sobre a atuação de agentes políticos indígenas e não-indígenas, e as Organizações Indígenas que rompem com este pacto implícito têm sua legitimidade comprometida. Nesse âmbito, as interações entre lideranças de Organizações Indígenas e suas bases devem ser concebidas como parte indissolúvel do sistema de relações recíprocas, no qual mandatos e prestígio são trocados por bens e serviços captados nas instituições do mundo do branco.

A importância das relações de reciprocidade faz com que influenciem nas formas de atuação etnopolítica no Alto Rio Negro, onde a acumulação - real ou atribuída - de bens e de prestígio obtidos nas agências de contato pode disparar os mecanismos reguladores como o manhene, ameaçando a continuidade de iniciativas bem-sucedidas, como vem ocorrendo na Oibi. Tal contingência obriga as lideranças a agir em consonância com as expectativas de seus liderados, voltando suas pautas de atuação para a satisfação de demandas e pressões de sua base comunal, sob pena de perda de seus mandatos.

A pesquisa mostra uma sociedade imersa em transformações históricas, mas preservando espaços como o doméstico - mais resistente a mudanças e mais favorável à reprodução da ordem social -, onde costuma ocorrer a legitimação e deslegitimação das chefias políticas. O plano doméstico pode fornecer o entendimento das razões pelas quais lideranças e ações políticas aparentemente bem-sucedidas podem ser sacrificadas à norma social. É inegável, porém, que as novas condições enfrentadas pelos Baniwa promovem conflitos e contradições, gerando alterações funcionais nas relações internas de sua sociedade e acarretando mudanças na estrutura social, que por sua vez retroalimentam as relações internas de poder.

No entanto, as disputas e tensões cotidianas de consangüíneos e afins, nas quais os conflitos intra e intertribais falam mais alto, evidenciam a inadequação da idéia de representação democrática, as dificuldades de estabelecer identidades étnicas genéricas e de viabilizar um movimento indígena pan-rionegrino. Organizações indígenas, conselhos de saúde e o trabalho do agente de saúde podem ser formas institucionalizadas de atuação política, mas elas também são perpassadas pela lógica da organização social nativa que as precede, instaurando-se uma contínua retroalimentação entre estes dois planos da existência. 
Aqui cabe, outra vez, a reflexão sobre as implicações dessas pré-condições enfrentadas pela ação etnopolítica. O movimento indígena rionegrino pode guardar muitas semelhanças com outros movimentos sociais; nele podemos encontrar o espirit de corps, as utopias de transformação social, a produção de novas relações identitárias e a institucionalização; entretanto ele não se deixa capturar e reduzir a estas similaridades. As identidades genéricas e o pragmatismo da 'etnicidade de resultados', que tem preocupado os estudiosos, são peças-chave nestes embates e, pelo menos na realidade analisada, não têm sido estratégias construídas à revelia e/ou em oposição às prioridades e rumos definidos pela base político-comunal. Elas têm sido, ao contrário, meios pelos quais lideranças em busca de legitimidade têm viabilizado uma maior aproximação com sua base de apoio político.

A explicação desses eventos a partir de injunções exteriores, que inegavelmente existem, não é suficiente para abarcar toda a complexidade dessa dinâmica social. Se as lideranças parecem se curvar docilmente às pressões e determinações de aliados não-indígenas, é porque isso recobre uma complementaridade com demandas internas de uma realidade na qual os liderados buscam, por meio da ação etnopolítica, obter uma inserção menos assimétrica na sociedade globalizada. A visível prioridade dada à faceta gerencial, responsável por boa parte do sucesso obtido por suas entidades, é algo mais do que um mero aceder às ingerências dos atores políticos externos; ela é parte de uma motivação profunda oriunda dos planos internos dos grupos de sustentação do movimento, os quais vêm pressionando seus etno-representantes por melhorias objetivas em suas condições de vida. Tais características conferem um caráter inegavelmente endo-referido às bases de sustentação política do movimento indígena praticado no Alto Rio Negro.

A relação com o mundo não-indígena, marcada pelo incremento da institucionalização das entidades indígenas, é influenciada pela conjugação entre o refluxo de investimentos do Estado brasileiro em políticas sociais e a trajetória de lideranças que, segundo suas próprias palavras, estão cansadas de ler infindáveis denúncias e relatórios catastróficos sobre as más condições de vida dos povos indígenas, sem que se obtenha alteração significativa neste cenário; em razão disso, elas explicitam o desejo de participar de políticas de intervenção, capazes de mudar tal estado de coisas. A busca de melhoria nas condições de vida é parte de uma tomada de decisão da política indígena praticada na Amazônia, que vem priorizando intervenções concretas na vida social ainda que feitas por intermédio de alianças com agentes políticos não indígenas, cujos propósitos tentam subverter em benefício de seus povos. Se irão obter sucesso neste intento, só o futuro será capaz de dizer.

A trajetória percorrida pelas lideranças do movimento indígena remete às relações entre sujeitos e estrutura social e permite apreender as diversas formas como a última pode moldar ações humanas e eventos sociopolíticos, e como os 
primeiros podem transformar tais constrangimentos, modulando-os segundo as condições sociopolíticas que enfrentam e os esquemas valorativos que orientam suas ações. Apesar da possibilidade de recriação da vida social pelos sujeitos, os dados também evidenciaram que suas ações não se constituem no vazio, tendendo a assumir configurações próximas àquelas previamente disponíveis no acervo cultural que define sua visão de mundo.

As práticas dos membros da sociedade baniwa são simultaneamente permeadas pelos saberes míticos e pelas visões, proposições e valores do mundo não indígena, sejam os veiculados por missionários, militares e outros agentes de colonização, sejam as idéias de valorização da etnicidade e do meio ambiente, cuja principal fonte emissora são as entidades de solidariedade internacional. Ainda que a apropriação dessas noções se processe de forma desigual entre os membros da sociedade, ela é suficiente para demonstrar que a hegemonia do mundo nãoindígena nas formas de ser baniwa pode ser obtida não apenas pela dominação e pela força, mas também pelo convencimento e pela incorporação desses princípios e ideologias na vida cotidiana. Trata-se, no entanto, de uma reprodução nãomonolítica, comportando, ao contrário, uma infinita variedade no tempo, no espaço e nos diversos segmentos da sociedade.

A diversidade de interesses, disparidade de opiniões e de formas de relação entre pessoas que ocupam papéis sociais distintos na sociedade baniwa afasta a possibilidade de consensos fáceis e instaura a necessidade de uma permanente negociação entre os agentes políticos, pois cada grupo em interação tenta reforçar sua respectiva posição e fazer valer as necessidades que prioriza. A instabilidade da delegação de poder para o exercício da mediação interétnica é parte intrínseca dos modos de operar do movimento indígena e evidencia a vitalidade da influência das relações de parentesco.

Retomando a perspectiva de Sahlins (1988), verifica-se que as diferentes dimensões assumidas pela atividade etnopolítica se configuram, no momento flagrado pela pesquisa, mais como uma variação na expressão das estruturas de sua sociedade do que numa mudança radical na cultura do povo baniwa. É um caso em que a continuidade se expressa pela mudança: mudam-se as formas de lidar com a sociedade global, mudam-se os requisitos para legitimação e para orientação da ação dos atores políticos, mudam-se os instrumentos de trabalho requeridos a este tipo de atividade, altera-se o vocabulário e a etiqueta, mas mantêm-se as relações constitutivas da ordem nesta sociedade. Por quanto tempo? Que configuração assumirá no futuro um processo que contém em si mesmo o germe da negação da hierarquia de gênero e de geração, os pilares da reprodução da ordem social e cosmológica?

Não existem respostas possíveis no momento, pois a mudança cultural não se dá de acordo com lógicas preestabelecidas, seja de ideologias oriundas do 
mundo não-indígena, seja daquelas prescritas pela cultura de origem dos sujeitos, ocorrendo de muitas formas imprevisíveis e contraditórias, ao sabor de experiências e acordos firmados em processo e ordenados não apenas em função de problemas a serem resolvidos e de necessidades a serem satisfeitas, mas também dos ideais e compromissos éticos que permeiam a ação política organizada.

A cultura baniwa vem sobrevivendo à abolição de importantes rituais, como o de passagem, remetendo tais simbolizações - essenciais para a produção de seus membros adultos - ao plano da invisibilidade doméstica. Ao aprimorar o mimetismo até a perfeição, obscureceram as profundas diferenças com os brasileiros que vivem em torno de seu território. Durante um longo período de sua história, muitos Baniwa se 'disfarçaram de brancos' para permanecerem índios, e num determinado momento o movimento indígena surgiu no cenário, preconizando a inversão dessas estratégias e a utilização ostensiva dos estigmas da cultura como uma nova forma de viver a etnicidade, gerando novas incertezas e contradições na vida comunal.

A militância etnopolítica também promoveu outra contradição aparentemente insolúvel, a de como conciliar a individualização efetivada na mediação interétnica com os preceitos de uma cultura organizada para priorizar o grupo em detrimento dos indivíduos. A crise instaurada pela doença do dirigente da Oibi expõe claramente esta contradição; mesmo não sendo alvo de qualquer acusação de apropriação individual dos bens e prestígio auferidos à frente da entidade, o simples sucesso obtido como resultado de seu trabalho foi o suficiente para desencadear reações hostis entre os membros de sua base de apoio, numa sinalização explícita de que sua atuação ultrapassara os limites considerados toleráveis pela sociedade. $\mathrm{O}$ evento surge como uma manifestação singular de doença, mas ilustra o processo coletivo de controle político exercido sobre os agentes de modernização.

O episódio está longe de seu desfecho, mas suas conseqüências já são claramente perceptíveis para todo o movimento indígena baniwa, tendo-se gerado uma expectativa sobre o desfecho do episódio de envenenamento; caso sejam negativas, desenha-se uma tendência de retração no crescimento das atividades das entidades de base, pois várias lideranças vêm expressando o receio de seguir a mesma trajetória e se expor aos mesmos riscos.

$\mathrm{Na}$ conjuntura atualmente instalada, os membros da sociedade baniwa se vêem frente a frente com um contraditório enfrentamento de tradição e modernidade. Por um lado os meios de controle da individualização representam um dos pilares da organização da sociedade; por outro, as pressões oriundas do mundo exterior demandam a atuação de lideranças preparadas para enfrentar as difíceis negociações travadas com as instituições não-indígenas. É uma atividade cujo exercício exige um prolongado aprendizado, instaura uma trajetória que conduz a uma individualização que fere os princípios reguladores da ordem social. $O$ envenenamento do presidente da Oibi indica que até o momento a balança pende 
para a imolação de líderes e para a manutenção dos princípios que regem a vida política nesta sociedade.

As grandes discussões que perpassam as análises científicas sobre o movimento indígena surgiram em vários momentos da pesquisa, mas assumindo com freqüência configurações diferentes daquelas assinaladas pela literatura. Como exemplo podem ser citados os usos políticos da cultura pelo movimento indígena rionegrino, que tanto podem compreender estratégias de valorização da diferença étnica - algumas vezes inclusive em oposição à sua negação pelos liderados quanto o borramento momentâneo de suas diferenças internas, através das quais operam segundo uma identidade genérica que expressa relações coletivas de forças, com base nas quais tentam fazer frente aos interesses e prioridades dos não-índios. Não sendo uma estratégia 'inautêntica', ela contém inúmeras e sutis conotações, devendo ser relida segundo o contexto de enunciação, o tipo de interlocutor e os propósitos do emissor do discurso, sem que represente, porém, um abandono da identidade clânica, operativa no plano local. O que se observa habitualmente neste campo é um jogo de superposição de imagens em busca de maior eficácia e rentabilidade na intervenção política.

As temáticas da autodeterminação, do direito à diferença e da autenticidade das lideranças encontram pouco eco no plano local, imerso em preocupações com o lado prático da vida e com as simbolizações da cosmologia do grupo. O descompasso entre as bandeiras gerais do movimento indígena e as prioridades 'das bases' têm colocado as lideranças ante a difícil tarefa de promover um encontro entre perspectivas divergentes e atender simultaneamente a interesses muito diversos de seus liderados. A militância na Organização Indígena de Base se configura como uma forma de poder local, dividida entre a necessidade de lidar com realidades e problemas supralocais e com as hierarquias do parentesco voltadas para o micro-universo da vida comunal. Ela enfrenta circunstâncias novas, engendradas nas relações interétnicas, como é o caso das políticas públicas que criam postos de representatividade genérica e produzem tensões que anteriormente não ocorriam.

Desafios antes nunca colocados para as chefias locais exigem uma mudança de estilo de atuação política e no perfil das lideranças, que devem se capacitar tecnicamente para o desempenho requerido para tais tarefas. A apropriação da linguagem da tecnoburocracia pelo movimento indígena faz parte de um conjunto de estratégias que buscam a intervenção e apropriação de políticas públicas e outras atividades desenvolvidas pelas entidades não-governamentais, como as ONGs de apoio à causa indígena. No caso da saúde, a possibilidade de participar na gestão de uma política setorial não é recusada por lideranças indígenas que buscam reafirmar suas posições no espaço interétnico de poder, seja pela intenção de colocá-la em andamento dentro das áreas indígenas, seja pela busca de recursos materiais ou simbólicos de saúde. 
As produções discursivas dos líderes indígenas mostram o domínio de diferentes formas e tipos de discurso (discurso científico, histórico, crítico, de denúncia etc.) que são acionados conforme a oportunidade (e necessidade), nas negociações com as agências de contato. Se necessário, eles também podem exibir, durante uma interlocução, uma postura ingênua ou alegar desconhecimento das regras da língua portuguesa; em tais situações é comum invocar a condição de índio, manipulando a etnicidade para melhor identificar e selecionar aliados e adversários no âmbito da sociedade nacional. No campo da saúde as estratégias são similares, pois nos espaços de negociação com representantes das instituições da sociedade nacional, as lideranças manejam e ressignificam sentidos e práticas sanitárias, biomédicas e indígenas, de forma a ampliar seu poder político tanto sobre a população citadina, quanto sobre a aldeada.

Esta prestidigitação exercitada pelas lideranças nos mostra a necessidade de ampliar o enfoque nos estudos do movimento indígena, evitando restringi-lo apenas aos mediadores em situações de intervenção no espaço interétnico, mas entendendo também as condições em que essa mediação se produz, o tipo de sociedade que lhe oferece a base de sustentação política e as redes de comunicação e de poder que se estabelecem nas cenas sociais onde ela é efetivada. Tais estudos deveriam compreender as formas de aprovisionamento da sociedade e da organização política do grupo, os processos geradores do poder atribuído aos mediadores e que são produzidos no interior de sistemas sociais em que não existe autoridade centralizada. Nesses, o exercício do poder perpassa o tecido social, e o cotidiano desempenha um importante papel na produção e reprodução das hierarquias e assimetrias, dispensando ou limitando a institucionalidade dos aparelhos de Estado. São cenários em que as iniqüidades porventura existentes são indissociáveis das relações de complementaridade e reciprocidade que são bem distintas, portanto, da realidade encontrada fora das fronteiras tribais.

A situação descrita para os Baniwa não pode ser automaticamente transferida para os outros povos indígenas, nem mesmo para outros grupos rionegrinos. Os dados devem ser tomados com cautela, pois as formas autóctones de organização social aqui descritas são específicas daquela realidade e vêm variando segundo as características assumidas pelas relações de contato. Apesar disiso, é impossível não pensar nas potenciais implicações desses achados para o desenvolvimento de políticas públicas dirigidas às minorias étnicas.

Obviamente as singularidades internas dos grupos indígenas moldam as demandas que eles dirigem às agências de contato, influenciando nos modos como interagem com elas. Tomando como exemplo as relações dos Baniwa com as instituições de saúde, foi possível observar que as prioridades e necessidades levadas aos conselhos de saúde são, de fato, configuradas por suas formas de interpretar a realidade, e que podem apresentar uma enganosa congruência com as prescrições 
biomédicas, devido ao uso de estratégias cognitivas de ancoragem que selecionam, dentre os novos saberes trazidos pelo contato, apenas aqueles que fazem algum sentido à luz dos conhecimentos prévios do grupo.

Entretanto, existe o outro lado da moeda. Seria pertinente que nos perguntássemos como se ordenam as expectativas e premissas da intervenção das instituições que interagem com os povos indígenas, particularmente porque seus modos de intervenção costumam ser etnocêntricos, congruentes com uma racionalidade tecnoburocrática, e se concretizam por meio de estratégias genéricas, aplicadas de forma indiferenciada a todos os grupos com os quais atuam.

As instituições prestadoras de serviços, e não raro os financiadores do movimento indígena, costumam representar os grupos indígenas como totalidades, ignorando que as divergências e faccionalismos não são um contratempo ou uma distorção, e sim uma parte indissociável da própria mentalidade indígena, voltada para microssegmentações identitárias. Em conseqüência alimentam a expectativa, implícita ou explícita, de que um representante indígena fale em nome dos interesses de todos os índios ou no mínimo de 'seu povo', traindo uma concepção pan-indigenista semelhante à que marcou os primeiros momentos organizativos do movimento indígena.

No subsistema de saúde indígena essas premissas também costumam ser aplicadas na escolha de conselheiros de saúde ou de agentes indígenas e na distribuição de postos de saúde e radiofonias. Nessas circunstâncias, o sistema de saúde, que trabalha com a noção de área de abrangência, ${ }^{1}$ costuma designar áreas de cobertura de profissionais e serviços, sem considerar a lógica própria de aglutinação político-demográfica indígena. A fixação de uma unidade de saúde em uma localidade, com a responsabilidade de prover atendimento a um conjunto de aldeias em suas proximidades, institui uma relação de dependência entre as comunidades, ferindo seu ideal autárquico e acirrando disputas pelos bens e prestígio advindos da presença de um serviço de saúde na aldeia. A presença de profissionais não-indígenas de saúde nas aldeias também costuma ser acompanhada de um acirramento de disputas clânicas, em que as facções disputam o controle político sobre a circulação dos produtos de seu trabalho, lutando para maximizar, para seu grupo de aliança, o acesso a eles. É freqüente que os profissionais da saúde, desconhecedores das linhas comunais de poder e autoridade, se verem envolvidos em disputas políticas que podem inviabilizar o desenvolvimento das rotinas sanitárias necessárias ao cumprimento das ações pactuadas com o sistema de saúde.

A razão técnica da biomedicina recomenda que a distribuição de insumos, como os medicamentos, seja feita em acordo com os diagnósticos médicos recebidos por seus clientes; assim, se uma pessoa recebe o diagnóstico de pneumonia, ela recebe também uma prescrição específica para tratamento do problema. Como anteriormente visto, um dos pilares da organização da vida comunal é o respeito 
às regras de reciprocidade, nas quais, conforme demonstrado por Garnelo (2001), a circulação de medicamentos já está inserida. Assim, a pressão comunal em busca de medicamentos, vista como um retorno de favores e serviços prestados entre parentes, também se choca com a racionalidade técnica que orienta a distribuição dos remédios segundo a patologia que devem tratar.

Sendo a redistribuição um dos elementos-chave para garantir o prestígio político e a legitimidade das chefias, a tendência a ser esperada é a utilização dos bens auferidos nas agências de contato, na manutenção de carreiras políticas, o que de fato ocorre. Não existem dados que permitam avaliar o impacto da utilização política de insumos destinados a execução de rotinas técnicas de serviços, mas pode-se inferir que tal uso - não previsto e não autorizado pelas instituições interfira negativamente no cumprimento de metas e objetivos pactuados nos planos de saúde, prejudicando o desempenho dos serviços.

As intervenções sanitárias costumam ser autoritárias, prescritivas e pouco permeáveis às formas indiretas de exercício do poder no mundo indígena, cujas chefias, desprovidas de poder de mando, dependem de sua capacidade de convencimento para obter a adesão de seus liderados. Os profissionais da saúde partilham a convicção da importância de seus saberes e repudiam a incapacidade, ou desinteresse, dos chefes indígenas de obrigar seus liderados a seguir as recomendações dos serviços de saúde. Além disso, equipes e serviços de saúde costumam encarar sua clientela como receptores passivos dos saberes biomédicos, ignorando a ativa reconstrução dos sentidos e objetivos das ações de saúde, que podem gerar resultados imprevisíveis nos processos educativos destinados à prevenção de doenças.

Tais situações testemunham os desencontros entre necessidades e expectativas nativas e as estratégias de implementação de políticas públicas supostamente diferenciadas para atender às necessidades nativas. $\mathrm{O}$ conhecimento das características de um grupo étnico deveria ser o eixo orientador de programas de intervenção dos órgãos públicos nas comunidades indígenas, mas não é o que ocorre. O estudo dos Baniwa fornece um exemplo da distância entre as necessidades desse povo e os serviços de saúde para eles disponibilizados, que são, como todos os.outros, pautados por uma perspectiva ocidentalizante, pela generalidade uniformizante e pela baixa sensibilidade às diferenças culturais. As complexas representações da doença e práticas de cura, as formas de conceber a autoridade, as alianças e desavenças entre os sibs e os circuitos de reciprocidade, embora sejam elementos essenciais da vida baniwa, são desconhecidos no sistema de saúde e conseqüentemente ignorados ou rejeitados na definição de prioridades de ação e de alocação de recursos destinados ao custeio dos serviços.

Tal situação, longe de ser uma exceção, caracteriza-se mais como regra na abordagem dos diversos grupos étnicos que vivem no Brasil. Habitualmente as 
agências de contato mostram-se incapazes de apreender as singularidades de cada grupo e desconhecem os modos como cada cultura, ou subgrupo dentro de uma totalidade cultural, lança mão de seu acervo próprio de recursos para - dentro de condições que lhes são impostas pelas configurações localmente assumidas pelo sistema-mundo - gerar respostas que viabilizem sua continuidade histórica. Os múltiplos processos engendrados por formações sociais locais que estabeleceram encontros coloniais são negados e homogeneizados na forma de subprodutos sempre iguais, ofertados a populações anônimas e indiferenciadas.

Habitualmente falar em participação indígena nas políticas públicas gera um desdobramento imediato: a identificação da necessidade de capacitá-los para promover a ampliação de seu conhecimento sobre o mundo não-indígena e aprimorar suas formas de intervenção no espaço das relações interétnicas. O cenário aqui descrito conduz ao sentido oposto: como as instituições devem fazer para se capacitar para intervir nessas sociedades e efetivar, por meio de práticas concretas, o ideal abstrato de respeito à diferença? Como devem fazer para lidar com a assimetria e a diferença sem tentar reduzir os diversos grupos indígenas a uma massa amorfa e indiferenciada? Enfim, como oferecer uma política pública efetivamente voltada para as necessidades daqueles a quem pretende servir?

Desafio similar se coloca para as próprias organizações do movimento indígena. Apesar das especificidades descritas nas páginas anteriores, também é perceptível que elas são forçadas a atuar de forma generalizante e que sua origem étnica não fornece uma garantia automática de respeito às diferenças culturais de seus representados. As organizações etnopolíticas atuam num precário equilíbrio entre o modelo racional-burocrático que orienta sua ação e os embates dos grupos tradicionais de poder que as constituem. Em entidades pequenas como as organizações de base da área baniwa, essas interações aparecem de forma bem explícita, mas são menos perceptíveis em associações maiores, que congregam um grande número de povos (e interesses), precariamente unidos sob a frágil bandeira do pan-indigenismo. Tais entidades enfrentam o desafio de conciliar a necessária formação de quadros técnicos profissionalizados - preparados para intervir criticamente em áreas complexas como a de políticas da saúde - com as prioridades definidas no plano dos costumes tradicionais; as demandas do parentesco podem se expressar, por exemplo, em solicitação de cargos assalariados para consangüíneos pouco qualificados para o desempenho de funções técnicas à frente das entidades. Nessas circunstâncias, como equilibrar o respeito às relações de reciprocidades e redistribuição de bens com metas e ações técnicas de projetos de etnodesenvolvimento ou de cuidados de saúde?

Esse conjunto de situações exemplifica o caleidoscópio de problemas vividos hoje pelos povos indígenas. Não existem respostas fáceis para os impasses e contradições aqui apontadas; caminhos e soluções terão que ser construídos pelos 
atores políticos indígenas e não-indígenas que enfrentam essa conjuntura e que atuam, transformando a ela e a si próprios numa engenhosa produção de identidadesprocesso, continuamente reconstruídas nos seus modos próprios de fazer a vida.

72 O conceito de área de abrangência considera a relação entre o quantitativo dos serviços oferecidos e o total de população a ser atendida. Segundo essa lógica, um agente indígena de saúde deve se responsabilizar pela prestação de cuidados sanitários dirigidos a uma população de 50 a 100 pessoas, residentes em áreas próximas ao posto de saúde onde atua. A definição da área de abrangência baseia-se essencialmente em critérios de distância física entre as moradias e os serviços de saúde. A população a ser atendida é vista como um grupo homogêneo unido pela proximidade geográfica; outras variáveis como conflitos de relacionamento ou ligações de parentesco entre residentes mais distantes não são consideradas. Obviamente tal sistema é conflitante com a forma própria de interação social dos grupos indígenas, cuja distribuição espacial obedece à dinâmica das alianças e conflitos do parentesco, não sendo congruente com a definição dos serviços de saúde. Em conseqüência, não é incomum que um agente de saúde se veja obrigado a desenvolver atividades em aldeias hostis ao seu grupo de parentes, relegando a segundo plano o trabalho com os membros de seu próprio sib; tais ocorrências costumam redundar em conflitos que prejudicam as atividades sanitárias. 
Mapa 1 - Comunidades indígenas no Alto e Médio Rio Negro

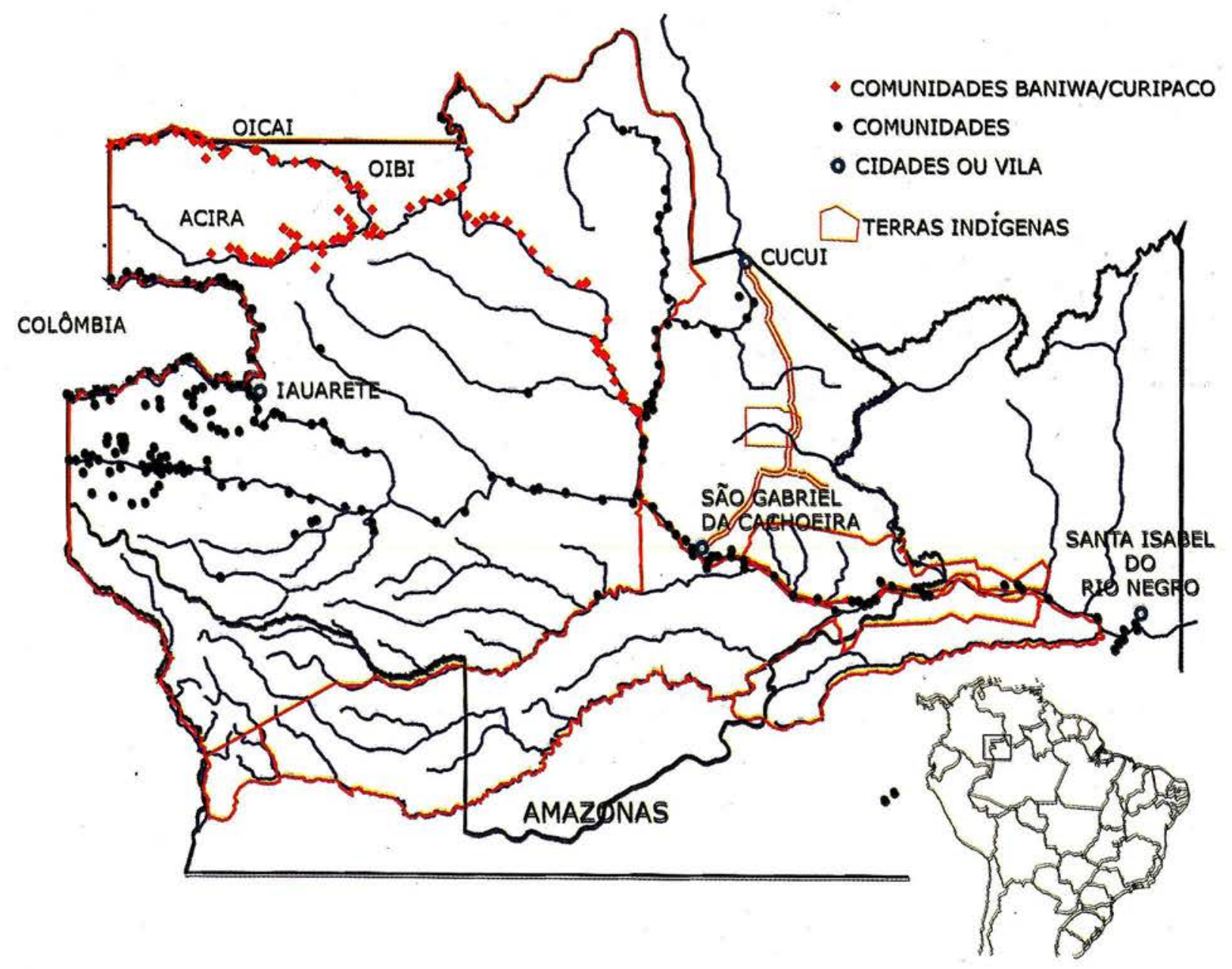


Mapa 2 - Distribuição ancestral e atual dos territórios por fratria

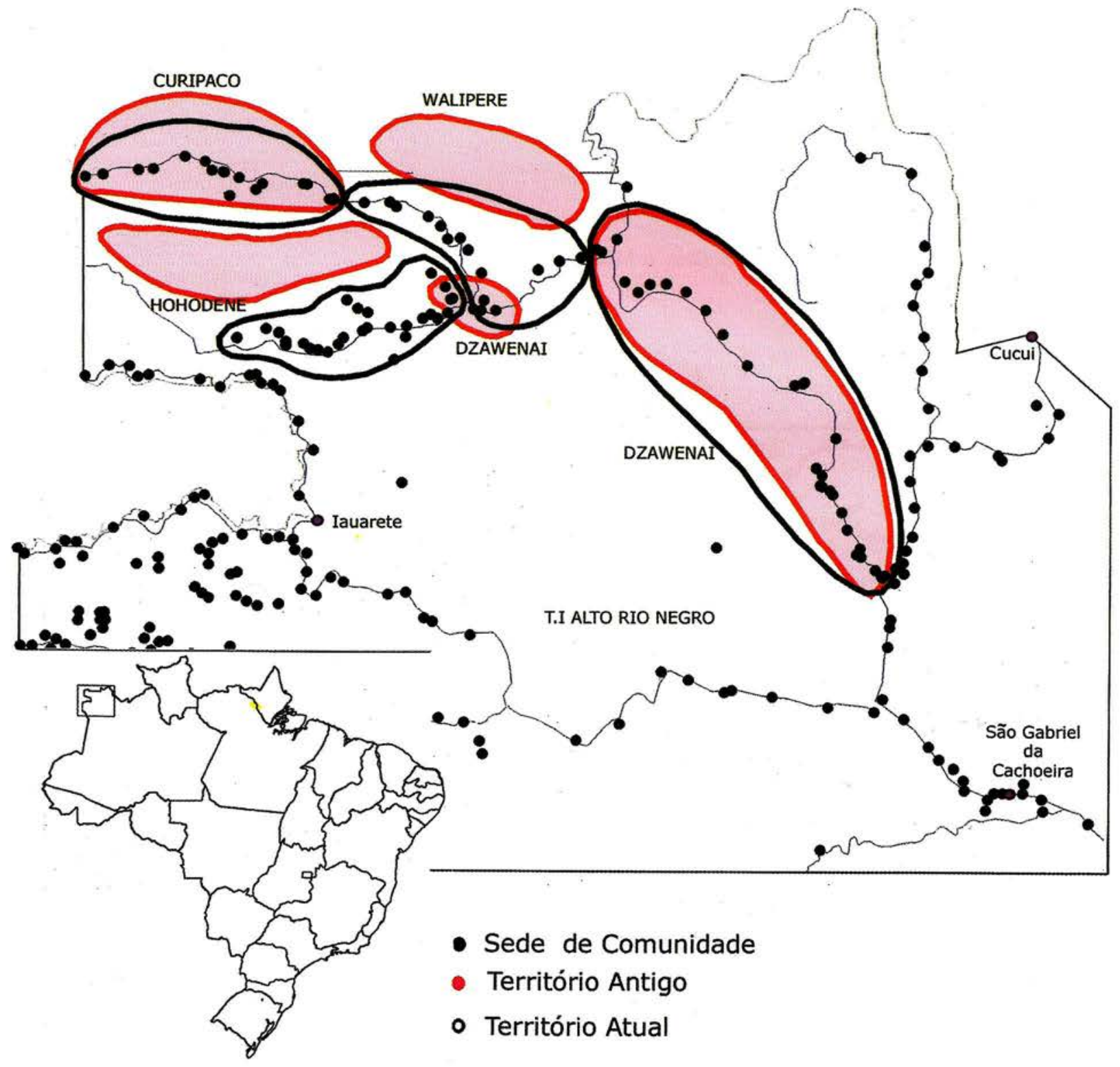

Fonte: Adaptado de ISA/Foirn, 1999 
Mapa 3 - Abrangência de organização indígena por fratria e sub-região

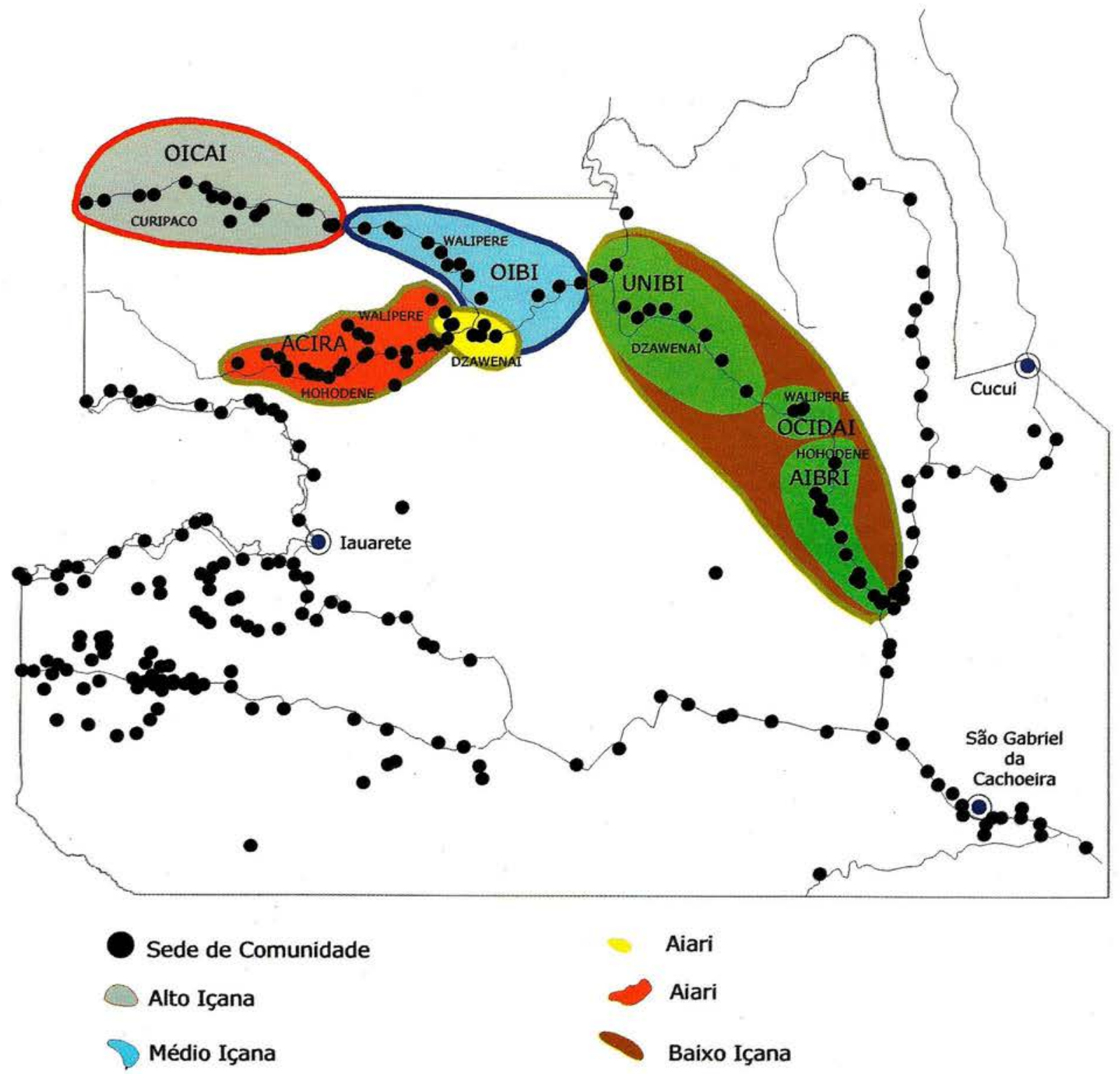

Fonte: Adaptado de ISA/Foirn, 1999 



\section{Referências Bibliográficas}

ABRIC, J-C. L'organization interne des représentations sociales: système central et système periphérique. In: GUIMELlI, C. (Org.) Structures et Transformations des Représentations Sociales. Neuchâtel: Delachaux et Niestlé, 1994.

ABRIC, J-C. Pratiques sociales, représentations sociales. In: Pratiques Sociales et Représentations. Paris: PUF, 1997.

ALBERT, B. Temps du Sang, Temps des Cendres: représentations de la maladie, systèm rituel et espace politique chez les Yanomami du sue-est (Amazonie brasilienne), 1988. Tese de Doutorado, Paris: Université de Paris X. Orston.

ALBERT, B. Terras indígenas, política ambiental e geopolítica militar no desenvolvimento da Amazônia: a propósito do caso Yanomami. In: LENA P. \& OLIVEIRA, A. E. (Orgs.) Amazônia: a fronteira agrícola 20 anos depois. Belém: Ed. MPEG, 1991.

ALBERT, B. O Ouro Canibal e a Queda do Céu: uma crítica xamânica da economia política da natureza. Brasília: Ed. UnB, 1995. (Série Antropológica)

ALBERT, B. Territorialité, ethnopolitique et developpement: à propos du mouvement indien en Amazonie bresilienne. Cahiers des Amériques Latines, 23:177-210, 1997a.

ALBERT, B. 'Ethnographic situation' and ethnic movements: notes on post-Malinowskian fieldwork. Critique of Anthropology, 17(1):53-65, 1997b.

ALBERT, B. Associações indígenas e desenvolvimento sustentável na Amazônia brasileira. In: RICARDO, C. A. (Org.) Povos Indígenas no Brasil, 1996/2000. São Paulo: Ed. Instituto Sócio-Ambiental, 2000.

ALTMAN, L. 'Madija' - um Povo entre a Floresta e o Rio: trilhas da produção simbólica Kulina, 1984. Dissertação de Mestrado, São Bernardo do Campo: Instituto Metodista Superior.

ARAMBURU, M. Aviamento, modernidade e pós-modernidade no interior amazônico. Revista Brasileira de Ciências Sociais, 25:81-99, 1994.

ARAÚJO, I. A dupla ilusão: uma leitura possível das relações discursivas entre brancos e índios. In: CONGRESSO BRASILEIRO DE CIÊNCIAS DE COMUNICAÇÃO/INTERCOM, XXI, 1998, Rio de Janeiro.

AUGÉ, M. L'Anthropologie de la maladie. L'Homme. XXVI(97-98):81-89, 1986. 
BARABAS, A. Utopias Índias: movimientos sociorreligiosos en Mexico. Mexico: Enlace/ Grijalbo, 1989.

BARTH, F. The analysis of Culture in complex societies. Ethnies, 3-4, 1988.

BARTH, F. Grupos étnicos e suas fronteiras. In: POUTIGNAT, P. \& STREIFF-FENART, J, Teorias da Etnicidade. São Paulo: Ed. Unifesp, 1998.

BARTOLOMÉ, M. Consciencia étnica y autogestión indígena. In: Indianidad y Descolonización en America Latina. p.309-323. Mexico: Nueva Imagen, 1979.

BARTOLOMÉ, M. Movimientos etnopolíticos y autonomías. America Indigena, 1-2:361382, 1995.

BOURDIEU, P. Le Sens Pratique. Paris: Les Editions de Minuit, 1980.

BOURDIEU, P. O Poder Simbólico. Rio de Janeiro: Bertrand Russel, 1989.

BOURDIEU, P. A Economia das Trocas Lingüísticas. São Paulo: Edusp, 1996a.

BOURDIEU, P. Razões Práticas: sobre a teoria da ação. São Paulo: Papirus, 1996b.

BUCHILLET, D. Maladie et Memoire des Origenes chez les Desna du Uaupés (Brésil), 1983. Tese de Doutorado, Paris: Université de Paris X. Orston.

BUCHILLET, D. Interpretação de doença e simbolismo ecológico entre os índios dessana. Boletim Museu Paraense Emilio Goeldi, 4(1):27-42, 1988. (Série. Antropologia)

BUCHILLET, D. Los poderes del hablar: terapia y agresión chamánica entre los indios Desana del Vaupes brasilero. In: BRASSO, E. \& SHERZER, J. (Orgs.) Las Culturas Nativas Latinoamericanas atraves de su Discurso. Quito: Abya-Yala, 1990. (Col. 500 años)

BUCHILlET, D. Os Índios da Região do Alto Rio Negro: história, etnografia e situação de terras. Brasília, 1991a. (Mimeo.)

BUCHILLET, D. Pari Cachoeira: o laboratório tukano do projeto Calha Norte. In: RICARDO, C. A. (Ed.) Aconteceu Especial, Povos Indígenas do Brasil, 1987/88/89/90/91. São Paulo: Ed. Cedi, 18:107-115, 1991b.

BUCHILLET, D. A antropologia da doença e os sistemas oficiais de saúde. In: . Medicinas Tradicionais e Medicina Ocidental na Amazônia. p.22-33. Belém: Ed. Cejup/MPEG/ UEP, 1991c.

BUCHILLET, D. Representações e práticas de medicinas tradicionais. Introdução In: Medicinas Tradicionais e Medicina Ocidental na Amazônia. Belém: Ed. Cejup/MPEG/ UEP, 1991d.

CHERNELA, J. Gender, language, and placement in Uanano song litanies. Journal of Latin American Lore, 14:2 193-206, 1988a.

CHERNELA, J. Righting history in the Northwest Amazon: myth, structure, and history in an arapaço narrative. In: HILL, J. (Org.) Rethinking History and Myth: indigenous South American perspectives on the past. Urbana: University of Illinois Press, 1988b.

CHERNELA, J. The ideal speech moment: women and narrative performance in the Brazilian Amazon. Feminist studies, 29(1):73-96, 1997.

CHESNEAUX, J. Modernidade-Mundo. Petrópolis: Vozes, 1996. 
CLASTRES, P. Arqueologia da Violência: ensaio de antropologia política. São Paulo: Brasiliense, 1982.

CLASTRES, P. A Sociedade contra o Estado: pesquisas de Antropologia Política. São Paulo: Brasiliense, 1990.

CHERNELA, J. Gender, language, and placement in Uanano Song Litanies. Journal of Latin American Lore, 14:2 193-206, 1988a.

CHERNELA, J. Righting history in the Northwest Amazon: myth, structure, and history in an arapaço narrative. In: HILL, J. (Org.) Rethinking History and Myth: indigenous south american perspectives on the past. Urbana: University of Illinois Press, 1988b.

CHERNELA, J. The ideal speech moment: women and narrative performance in the Brazilian Amazon. Feminist studies, 29(1):73-96, 1997.

COHEN, J. Strategy or identity: new theoretical paradigms and contemporary Social Movements. Social Research, 52(4):663-716, 1985.

COHEN, J. \& ARATO, A. Civil Society and Political Theory. Cambridge: Mit Press, 1992.

COPANS, J. Antropologia política. In: primitivas? Lisboa: Ed. 70, 1971. Antropologia. Ciência das Sociedades

DESCOLA, P. La Selva Culta: simbolismo y praxis en la ecologia de los Achuar. Quito: Abya-Yala, 1989.

DOIMO, A; DOXSEY, J. \& BELING, N. R. Os novos movimentos sociais: teoria e prática. Ciências Sociais Hoje, [s.n.]:8-36. São Paulo: Cortez/Anpocs, 1986.

DOUGLAS, M. Pureza e Perigo. São Paulo: Perspectiva, 1976.

FAULHABER, P. Uma viagem ao 'mundo de lá': imaginário e movimento dos índios no Jupará-Solimões. In: BARABAS, A. (Org.) Religiosidad y Resistencia Indígenas hasta el fin del Milenio. Quito: Abya-Yala, 1994.

FERNANDES, R. Privado, porém Público: o terceiro setor na América Latina. Rio de Janeiro: Relume Dumará, 1994.

FLAMENT, C. Structure, dynamique et transformation des représentations sociales In: ABRIC, J-C. Pratiques Sociales et Représentations. Paris: PUF, 1997.

GARNELO, L. Projeto Rede Autônoma de Saúde Indígena: uma experiência de educação e comunicação em saúde indígena. In: VASCONCELOS, E. (Org.) A Saúde nas Palavras e nos Gestos: reflexões da Rede de Educação Popular e Saúde. p.237260. São Paulo: Hucitec, 2001a.

GARNELO, L. (Org.) Manual de Doenças Tradicionais Baniwa. Manaus: Ed. Universidade do Amazonas, 2001b.

GARNELO, L. \& WRIGHT, R. Doença, cura e serviços de saúde: representações, práticas e demandas baniwa. Cadernos de Saúde Pública, 17(2):273-284, 2001.

GOHN, M. da G. Participação e gestão popular na cidade. Serviço Social e Sociedade, 26:25-47, 1988.

GOHN, M. da G. Teorias dos Movimentos Sociais: paradigmas clássicos e contemporâneos. São Paulo: Loyola, 1997. 
HILL, J. Social equality and ritual hierarchy: the Arawakan Wakuenai of Venezuela. American Ethnologist, 11(3):528-544, 1984.

HILL, J. Wakuenai cerimonial exchange in northwest Amazon. Journal of Latin American Lore, 13(2):183-224, 1987.

HILL, J. The soft and the stiff: ritual power and mythic meaning in a northern Arawak classifier system. Antropologica, (68):55-77, 1988.

HILL, J. Keepers of the Sacred Chants: the poetics of ritual power in an amazonian society. Tucson: University of Arizona Press, 1989.

HILL, J. 'Muzicalizing' the other: shamanistic approaches to ethnic-class competition along the Upper Rio Negro. In: BARABAS, A. (Org.) Religiosidad y Resistencia Indigenas hasta el fin del Milenio. Quito: Abya-Yala, 1992.

HILL, J. Cosmology and situation of contact in Upper Rio Negro basin. In: TURNER, T. (Org.) South American Studies: cosmology, values and inter-ethnic contact in South America, 2:42-51, 1993.

HILL, J. \& WRIGHT, R. Time, narrative, and ritual: historical interpretations from an amazonian society. In: HILL, J. (Org.) Rethinking History and Myth: indigenous south american perspectives on the past. Urbana: University of Illinois Press, 1986.

HUGH-JONES, S. The Palm and the Pleiades - initiation and cosmology in Northwest Amazonia. London: Cambridge University Press, 1979a.

HUGH-JONES, C. From the milk river. Spatial and temporal processes in Northwest Amazonia. Cambridge: Cambridge University Press, 1979b.

IANNI, O. Teorias da Globalização. Rio de Janeiro: Civilização Brasileira, 1995.

IANNI, O. A Era do Globalismo. Rio de Janeiro: Civilização Brasileira, 1996.

JACKSON, J. The Fish People, Linguistic Exogamy and Tukano Identity in Northwest Amazonia. London: Cambridge University Press, 1983.

JACKSON, J. Gender relations in the central northwest Amazon. Antropologica, 70:17$38,1988$.

JACKSON, J. The meaning and message of symbolic sexual violence in tukanoan ritual. Anthropological Quartely, 65(1):1-18, 1992.

JOURNET, N. Los Curipaco del rio Içana: economia y sociedad. Revista Colombiana de Antropología, XXIII:125-182, 1980-1981.

JOURNET, N. La Paix des Jardins: structures sociales des indiens curipaco do Haut Rio Negro (Colombia). Paris: Ed. Musée de L'Homme/CNRS, 1995.

KOCH-GRÜMBERG, T. Dos años entre los índios. Bogota: Editorial Universidad Nacional, 1995. v. I e II.

KUSHINIR, K. \& CARNEIRO, L. As dimensões subjetivas da política: cultura política e antropologia da política. Estudos Históricos, (24):227-245, 1999.

LANGDON, J. Representações de doença e itinerário terapêutico dos siona na Amazônia colombiana. In: SANTOS, R. V. \& COIMBRA JR., C. (Orgs.) Saúde e Povos Indígenas. Rio de Janeiro: Ed. Fiocruz, 1994. 
LAPlANTINE, F. Antropologia da Doença. São Paulo: Martins Fontes, 1991.

LATOUCHE, S. A Ocidentalização do Mundo. Petrópolis: Vozes, 1996.

LEIS, H. A Desordem ecológica na Amazônia e a desordem político-econômica da ordem internacional. In: ARAGÓN, L. A Desordem Ecológica na Amazônia. Belém: Ed. UFPA, 1991. (Série Cooperação Amazônica)

LÉVI-STRAUSS, C. Las regras de la buena educación. In: __. El Origen de las Maneras de Mesa. Mitologicas III. Mexico: Siglo Veinteuno, $19 \overline{84}$.

MAGALHÃES, E. O Estado e a Saúde Indígena: a experiência do distrito sanitário yanomami, 2000. Tese de Doutorado, Brasília: Universidade de Brasília.

MELUCCI, A. The new social movements: a theoretical approach. Social Science Information, 19(12):199-226, 1980.

MELUCCI, A. Movimentos sociais, renovação cultural e o papel do conhecimento. Novos Estudos Cebrap, 40:152-166, 1994.

MOSCOVICI, S. Des representations colletives aux représentations sociales. In: JODELLET, D. (Org.) Les Représentations Sociales. Paris: PUF, 1989.

OLIVEIRA, A. A terminologia de parentesco baniwa. Boletim Museu Paraense Emílio Goeldi, 56:1-36, 1975.

OLIVEIRA, A. Depoimentos baniwa sobre as relações entre índios e 'civilizados' no Rio Negro. Boletim Museu Paraense Emílio Goeldi, 72:1-31, 1979.

OLIVEIRA, A. G. Índios e Brancos no Alto Rio Negro: um estudo da situação de contato dos Tariana, 1981. Dissertação de Mestrado, Brasília: Universidade de Brasília.

OLIVEIRA, A. G. O Mundo Transformado: um estudo da cultura de fronteira no Alto Rio Negro. Belém: Ed. MPEG/PR/MCT/CNPq, 1995.

OLIVEIRA, A. \& GALVÃO, E. A situação atual dos Baniwa (Alto Rio Negro). Boletim Museu Paraense Emilio Goeldi, 20:27-40, 1973.

OLIVEIRA FILHO, J. P. O 'Nosso Governo': os Tikuna e o regime tutelar. São Paulo: Marco Zero/CNPq, 1987.

OLIVEIRA FILHO, J. P. Segurança das fronteiras e o novo indigenismo: formas e linhagens do Projeto Calha Norte. In: Janeiro: Peti/Ed. UFRJ, 1990. Antropologia e Indigenismo, (1):15-33. Rio de

ORTIZ, R. Cultura e Modernidade. São Paulo: Brasiliense, 1992.

ORTIZ, R. Mundialização e Cultura. São Paulo: Brasiliense, 1994.

ORTIZ, R. Um Outro Território: ensaios sobre a mundialização. São Paulo: Olho D’água, [s.d.].

ORTOLAN MATOS, MA. H. O Processo de Criação e Consolidação do Movimento PanIndígena no Brasil (1970-1980), 1997. Dissertação de Mestrado, Brasília: Universidade de Brasília.

OVERING, J. Elementary structures of reciprocity: a comparative note on Guianese, Central Brazilian, and North-West Amazon socio-political thought. Antropológica, 5962:331-348, 1983-1984. 
RAMOS, A. Indian voices: contact experiencied and expressed. In: HILL, J. (Org.) Rethinking History and Myth: indigenous south american perspectives on the past. Urbana: University of Illinois Press, 1988.

RAMOS, A. O Brasil no movimento indígena americano. In: Anuário Antropológico/82. Fortaleza/Rio de Janeiro: Ed. Universidade Federal do Ceará/Tempo Brasileiro, 1994.

RAMOS, A. The indigenous movement in Brazil: a quarter century of ups and downs. Cultural Survival Quartely, 211(2):50-53, 1997.

RICARDO, C. A. Os índios e a sociodiversidade nativa contemporânea no Brasil. In: SILVA, A. \& GRUPIONI, L. (Orgs.) A Temática Indígena na Escola: novos subsídios para professores do primeiro e segundo graus. Brasília: Ed. MEC/Mari/Unesco, 1995.

SAHLINS, M. Economia de la Edad de Piedra. Madrid: Akal/Universitaria, 1983.

SAHLINS, M. Cosmologias do capitalismo: o setor trans-pacífico do 'sistema mundial'. In: REUNIÃO BRASILEIRA DE ANTROPOLOGIA, XVI, 1988, São Paulo.

SAHLINS, M. Ilhas de História. Rio Janeiro: Zahar, 1990.

SAHLINS, M. O 'pessimismo sentimental' e a experiência etnográfica: por que a cultura não é um 'objeto' em via de extinção. Mana, 3(1):41-73, Parte I , 1997a.

SAHLINS, M. 'O 'pessimismo sentimental' e a experiência etnográfica: por que a cultura não é um 'objeto' em via de extinção. Mana, 3(2):41-73. Parte II , 1997b.

SAILLANT, F. \& GAGNON, E. Vers une anthropologie des soins? Anthropologie et Sociétes: soin, corps, alterite, 23(2):5-39, 1999.

SAMAJA, J. A Reprodução Social e a Saúde. Salvador: Casa da Qualidade Ed., 2000.

SAMPAIO, S. Conferências Bíblicas: religião e estratégias políticas no mundo baniwa, 2000. Monografia, Manaus: Universidade Federal do Amazonas.

SANTOS, R. História Econômica da Amazônia. São Paulo: TAQ Editor, 1980.

SANTOS-GRANERO, F. Poder, ideologia y rituales de production en las sociedades indigenas amazonicas. Amazonia Peruana, Tomo X (19):27-61, 1990.

SANTOS-GRANERO, F. From prisoner of the group to darling of the gods. L'Homme, 26128, XXXIII (2-4):213-230, 1993.

SANTOS-GRANERO, F. El Poder del Amor: poder, conocimiento y moralidad entre los Amuesha de la selva central del Perú. Quito: Abya-Yala, 1994.

SINDZINGRE, N. La nécessité du sens: l'explication de l'infortune chez les Senufo. In: AUGÉ, M. \& HERZLICH, N. (Orgs.) Le Sens du Mal: anthropologie, histoire, sociologie de la maladie. Paris: Ed. des Archives Contemporaines, 1984.

SINDZINGRE, N. \& ZEMPLÉNI, A. Modeles et pragmatique, activation et repetition: reflexions sur la causalite de la maladie chez les senufo de cote d'Ivoire. Social Science and Medicine, 15b:279-293, 1981.

SMITH, R. C. A. Amazonian indian participate at UN. Cultural Survival Quartely, 8(4):2031b, 1986. 
SMITH, R. C. A. Indigenous autonomy for grassroots development. Cultural Survival Quartely, 11(1):8-12, 1987.

SWARTZ, M.; TURNer, V. \& TUDEN, A. Political Anthropology. Chicago: Aldine Publishing Company, 1966.

SZTOMPKA, P. The Sociology of Social Change. Cambridge: Cambridge University Press, 1993.

TOURRAINE, A. Palavra e Sangue. Campinas: Ed. Unicamp, 1989.

TOURRAINE, A. Os movimentos sociais. In: Ed. Livros Técnicos e Científicos, 1998. . Sociologia e Sociedade. Rio de Janeiro:

TURNER, T. Os Mebengokre Kayapó: história e mudança social. In: CARNEIRO DA CUNHA, M. (Org.) História dos Índios no Brasil. São Paulo: Cia. das Letras, 1992.

TURNER, T. Da cosmologia à história. In: VIVEIROS DE CASTRO, E. \& CARNEIRO DA CUNHA, M. (Orgs.) Amazônia: etnologia e história indígena. São Paulo: NHII /USP/ Fapesp, 1993a.

TURNER, T. From cosmology to ideology: resistence, adaptation and social consciousness among the Kayapó. In: TURNER, T. (Org.) South American Studies: cosmology, values and inter-ethnic contact in South America, 2:1-13, 1993b.

TURNER, T. History, myth, and social consciousness among Kayapó of Central Brazil. In: HILL J. (Org.) Rethinking Myth and History. Urbana: University of Illinois Press, 1998.

VERÓN, E. A Produção do Sentido. São Paulo: Cultrix/USP, 1980.

VIOLA, E. A Multidimensionalidade da globalização, as novas forças sociais transnacionais e seu impacto na política ambiental no Brasil, 1989-1995. In: FERREIRA, L. \& VIOLA, E. (Orgs.) Incertezas de Sustentabilidade na Globalização. Campinas: Ed. Unicamp, 1996.

VIVEIROS DE CASTRO, E. Escatologia pessoal e poder entre os Araweté. Religião e Sociedade, 13/3:3-26, 1986.

VIVEIROS DE CASTRO, E. Os pronomes cosmológicos e o perspectivismo ameríndio. Mana, 2(2):115-145, 1996.

WAGLEY, C. Uma Comunidade Amazônica. São Paulo: Cia. Editora Nacional, 1977. (Coleção Brasiliana)

WEIGEL, V. Escola de Branco em Maloca de Índio. Manaus: Ed. Universidade do Amazonas, 2001.

WRIGHT, P. Perspectivas teoricas en la antopologia de los movimientos sociorreligiosos do Chaço Argentino. In: BARABAS, A. (Org.) Religiosidad y Resistencia Indígenas hasta el fin del Milenio. Quito: Abya-Yala, 1994.

WRIGHT, R. Hidden enemies: Baniwa witchcraft and sorcery. In: WHITEHEAD, N. \& WRIGHT, R. (Orgs.) Dark Shamans: the anthropology of assault sorcery in Amazonia. Duke University Press. (no prelo)

WRIGHT, R. Prophetic Traditions among the Baniwa. (no prelo)

WRIGHT, R. The History and Religion of the Baniwa Peoples of the Upper Rio Negro Valley, 1981. Tese de Doutorado, Ann Arbor: University Microfilms. Stanford University. 
WRIGHT, R. Uma história de resistência: os heróis baniwa e suas lutas. Revista de Antropologia, 30/31/32:355-381, 1987, 1988, 1989.

WRIGHT, R. Uma política de dividir-e-conquistar: os Baniwa, a mineração e o Projeto Calha Norte. In: ENCONTRO ANUAL DA ANPOCS, XIII (GT DE POLÍTICA INDIGENISTA), 1989, Caxambu.

WRIGHT, R. Guerras e alianças nas histórias dos Baniwa do Alto Rio Negro. Ciências Sociais Hoje, (12):217-236, 1992a.

WRIGHT, R. Baniwa-Curipaco-Wakuenai. In: Enciclopedia of World Cultures. New Haven: J. Wilbert Ed., 1992b.

WRIGHT, R. História indígena do noroeste da Amazônia: hipóteses, questões e perspectivas. In: CARNEIRO DA CUNHA, M. (Org.) História dos Índios no Brasil. São Paulo: Cia. das Letras, 1992c.

WRIGHT, R. 'Uma conspiração contra os civilizados': história, política e ideologias dos movimentos milenaristas dos Arawak e Tukano do noroeste da Amazônia. In: Anuário Antropológico/89, 191-231, Rio de Janeiro: Tempo Brasileiro, 1992d.

WRIGHT, R. Pursuing the spirit: semantic construction in Hohodene Kalidzmai chants for iniciation. Amerindia, (18):1-37, 1993.

WRIGHT, R. Umawali: Hohodene myths of the Anaconda, father of fish. Société Suisse des Américanistes Bulletin, (57/58):37-48, 1993/1994.

WRIGHT, R. Catastrophe and regeneration. In: BARABAS, A. (Org.) Religiosidad y Resistencia Indígenas hasta el fin del Milenio. Quito: Abya-Yala, 1994.

WRIGHT, R. Os guardiōes do cosmos: pajés e projetas entre os Baniwa. In: LANGDON, J. (Org.) Xamanismo no Brasil: novas perspectivas. Florianópolis: Ed. UFSC, 1996.

WRIGHT, R. Cosmos, Self and History in Baniwa Religion: for those unborn. Austin: University of Texas Press, 1998.

WRIGHT, R. (Org.) Waferinaipe Ianheke: a sabedoria dos nossos antepassados. S. Gabriel da Cachoeira: Ed. Foirn/Acira/ISA, 1999a.

WRIGHT, R. O tempo de Sophie: história e cosmologia da conversão Baniwa. In: (Org.) Transformando os Deuses: os múltiplos sentidos da conversão entre os povos indígenas no Brasil. Campinas: Ed. Unicamp, 1999b.

WRIGHT, R. Purity and contamination: millenarian traditions among the Baniwa and other Arawakan Peoples of the Northwest Amazon. In: INTERNATIONAL . CONFERENCE ON COMPARATIVE ARAWAKAN HISTORIES, 2000, Panama.

WRIGHT, R. \& HILL, J. History, ritual and myth: nineteenth century millenarian in the Northwest Amazon. Ethnohistory, 33(1):31-54, 1986.

YOUNG, A. The Anthropology of illness and sickness. Annual Review of Anthropology, 11:257-285, 1985. 


\section{Bibliografia}

AGIER, M. \& CARVALHO, M. do R. Nation, race, culture: les mouvements noirs et Indiens au Brésil. Cahiers des Amériques Latines, 17:107-124, 1994.

ALVES, P. C. \& RABELO, M. Antropologia da Saúde: traçando identidade e explorando fronteiras. Rio de Janeiro: Ed. Fiocruz/Relume Dumará, 1998.

ARAÚJO, I. A Reconversão do Olhar, 1995. Dissertação de Mestrado, Rio de Janeiro: Universidade Federal do Rio de Janeiro.

ARAÚJO, I. A batalha do Alto Rio Negro. In: REUNIÃo DA COMPÓS, VI, 1997, Caxambu.

ARVELO-JIMÉNES, N. Relaciones Políticas en una Sociedad Tribal: estudio de los ye'cuana, indígenas del Amazonas venezoelano. Mexico: Ed. Instituto Indigenista Interamericano, 1974.

ATHIAS, R. Doença e cura: sistema médico e representação entre os Hupdë-Maku da região do Rio Negro, Amazonas. Horizontes Antropológicos, 4(9):237-261, 1998.

ATHIAS, R. \& CHAGAS, D. Movimento indígena e associações indígenas: discurso e prática de uma política indígena no Rio Negro/AM. In: REUNIÃO DA ANPOCS NORTE E NORDESTE, IX (GT MOVIMENTO INDÍGENA, POLÍTICAS INDIGENISTAS E ESTRATÉGIAS DE GLOBALIZAÇÃO), 1999.

AUGÉ, M. Ordre biologique, ordre social: la maladie forme élémentaire de l'evenement In: AUGÉ, M. \& HERZLICH, C. (Orgs.) Le Sens du Mal: anthropologie, histoire, sociologie de la maladie. Paris: Ed. des Archives Contemporaines, 1984.

BALANDIER, G. Antropologia Política. São Paulo: Difel, 1969.

BALANDIER, G. Antropo-lógicas. São Paulo: Cultrix/Edusp, 1976.

BALANDIER, G. Para ver o poder. In: O Contorno: poder e modernidade. Rio de Janeiro: Bertrand Brasil, 1997.

BARBERO, J. De los Medios a las Mediaciones. Barcelona-Mexico: Ed. G. Gilli, 1987.

BARTH, F. The analysis of culture in complex societies. Ethnies, 3-4, 1988.

BARTH, F. Grupos étnicos e suas fronteiras. In: POUTIGNAT, P. \& STREIFF-FENART, J. Teorias da Etnicidade. São Paulo: Ed. Unifesp, 1998.

BARTOLOMÉ, M. La identidad residencial en Mesoamérica: fronteras étnicas y fronteras comunales. In: Anuário Antropológico/91. Rio de Janeiro: Tempo Brasileiro, 1993.

BELLIER, I. Réflexions sur la question du genre dans les sociétés amazoniennes, L'Homme, XXXIII(2-4):517-526, 1993.

BERGER, T. Native rights movements. Cultural Survival Quartely, 11(1):13-15, 1987.

BONFILL BATALLA, G. Las nuevas organizaciones indigenas hipoteses ara la formulación de un modelo analitico. In: BARTOLOMÉ, M. Indianidad y Descolonización en America Latina, p.23-40. Mexico: Nueva Imagen, 1979. 
BONFILL BATALLA, G. La teoria del control social en el estudio de los procesos étnicos. In: Anuário Antropológico. Brasília: Ed. UnB/Tempo Brasileiro, 1988.

BOURDIEU, P. A Dominação Masculina. Rio de Janeiro: Bertrand Brasil, 1999.

BROWN, M. Facing the state, facing the world: Amazonia's native leaders and the new politics of identity. L'Homme, 33(24):307-326, 1994.

BRUNELLI, G. De Los Espiritus a los Microbios: salud y cambio social entre los Zoró de Ia Amazonía brasileña. Quito: Abya-Yala, 1989.

BUCHILLET, D. Nobody is there to hear: desana therapeutic incantations. In: LANGDON, J. \& BAER, G. (Orgs.) Portals of Power. Albuquerque: University of New Mexico Press, 1992.

BUCHILlET, D. Contas de Vidro, Enfeites de Branco e 'Potes de Malária'. Brasília: Ed. UnB, 1995.

BUCHILLET, D. De la Colonie à la République: images de l'indien, politique et législation indigénistes au Brésil. Cahiers des Amériques Latines, 23:73-93, 1997.

CALDEIRA, T. P. Antropologia e poder: uma resenha de etnografias americanas. Recentes. $B I B, 27: 3-50,1989$.

CAVUSCENS, S. As Lutas Contemporâneas dos Povos Indígenas da Amazônia, 1999. Monografia, Manaus: Universidade Federal do Amazonas.

CHERNELA, J. Estrutura social do Uaupés. In: Anuário Antropológico, 81:59-108. Fortaleza/Rio de Janeiro: Ed. Universidade Federal do Ceará/Tempo Brasileiro, 1983.

CHIAPPINO, J. \& ALlEZ \& C. (Orgs.) Del Microscopio a la Maraca. Caracas: Exlibris, 1997.

CLAD, J. Conservation and the indigenous peoples. Cultural Survival Quartely, 8(4):6873, 1984.

CLAY, J. Organizing to survive. Cultural Survival Quartely, 8(4):2-13, 1984.

CLIFFORD, J. A Experiência Etnográfica: antropologia e literatura no século XX. Rio de Janeiro: Ed. UFRJ, 1998.

CONKLIN, B. Body paint, feathers, and VCR: aesthetics and authenticity in amazonian activism. American Ethnologist, 24(4):711-737, 1997.

CONKLIN, B. \& GRAHAM, L. The shifting middle ground: amazonian indians and ecopolitics. American Anthropologist, 97(4): 695-710, 1995.

DIAKURU \& KISIBI. A Mitologia Sagrada dos Desana-Wari. S. Gabriel: Unirt/Foirn, 1996.

DODGE, R. E. Povos Indígenas: direito, ética e controle social. In: CONFERÊNCIA NACIONAL DE SAÚDE INDÍGENA, III, 2001, Brasília.

DOYLE, M. Aspects of Baniwa Medicinal Flora and Ethnoecology. Manaus: Fundação Universidade do Amazonas, s.d. (Mimeo.)

FAULHABER, P. O Navio Encantado: etnia e alianças em Tefé. Belém: Ed. MPEG/ MCTCNPq, 1987. 
FAULHABER, P. O Lago dos Espelhos: etnografia do saber sobre a fronteira em Tefél Amazonas. Belém: Ed. MPEG/PR/MCT-CNPq, 1998.

FAURÉ, G. Constituição da interdisciplinaridade. In: PORTELA, E. et al. Interdisciplinaridade. Rio de Janeiro: Tempo Brasileiro, 1992.

FISHER, W. Megadevelopment, environmentalism, and resistance: the institutional context of Kayapó indigenous politics in Central Brazil. Human Organization, 53(3):220-232, 1994.

FOUCAULT, M. Microfísica do Poder. Rio de Janeiro: Graal, 1982.

FOX, R. Parentesco e Casamento: uma perspectiva antropológica. Lisboa: Ed. Veja, 1986.

GALLOIS, D. A categoria doença de branco: ruptura ou adaptação de um modelo etiológico indígena? In: BUCHILLET, D. (Org.) Medicinas Tradicionais e Medicina Ocidental na Amazônia. Belém: Ed. Cejup/MPEG/UEP, 1991.

GALLOIS, D. Xamanismo Waiãpi: nos caminhos invisíveis, a relação $i$-apie. In: LANGDON, J. (Org.) Xamanismo no Brasil. Novas Perspectivas. Florianópolis: Ed. UFSC, 1996.

GALVÃO, E. Aculturação indígena no Rio Negro. In: GALVÃO, E. Encontro de Sociedades: índios e brancos no Brasil. São Paulo: Paz e Terra, 1979.

GARNELO, L. Lutas e políticas de saúde no Alto Rio Negro. In: Anais do I Simpósio dos Povos Indígenas do Rio Negro: Terra e Cultura. Manaus: Ed. Universidade do Amazonas, 1997.

Garnelo, L. \& FIgUeroA, A. Proposta de Distrito Sanitário para o Alto Rio Negro. Relatório de Consultoria realizada para o Banco Mundial, 1992. (Mimeo.)

GODELIER, M. La Produción de los Grandes Hombres: poder y dominación masculina entre los Baruya de Nueva Guinea. Barcelona: Akal, 1986.

GOLDMAN, I. The Cubeo: indians of the Northwest Amazonia. Urbana: University of Illinois Press, 1963.

GOHN, M. da G. Conselhos populares, conselhos de cidadãos e participação popular. Serviço Social e Sociedade, 34:65-89, 1990.

GOODY, J. A Lógica da Escrita e a Organização da Sociedade. Lisboa: Ed. 70, 1986.

GOODY, J. A Domesticação do Pensamento Selvagem. Lisboa: Presença, 1988.

GROS, C. L'Indien est-il Soluble dans la modernite? Ou de quelques bonnes raisons de traitêr des amazonies indiennes. Caihers des Amériques Latines, 21:61-72, 1997.

HERRERA, X. Medicina tradicional y medicina institucional: el promotor de salud investiga los puntos de conflicto. In: BUCHILLET, D. (Org.) Medicinas Tradicionais e Medicina Ocidental na Amazônia. Belém: Ed. Cejup/MPEG/UEP, 1991.

HERZLICH, C. A problemática da representação social e sua utilidade no campo da doença. Physis - Revista de Saúde Coletiva, 1(2):24-57, 1991.

HILDEBRAND, M. VON. Gaia and culture: reciprocity and exchange in the Colombian Amazon. In: BUNYARD, P. (Org.) Gaia in Action. Edinburgh: Floris Books, 1993. 
HILL, J. El mito, la musica y la historia: transformaciones poéticas del discurso narrativo en una sociedad amazónica. In: BRASSO, E. \& SHERZER, J. (Orgs.) Las Culturas Nativas Latinoamericanas atraves de su Discurso. Quito: Abya-Yala, 1990. (Col. 500 años)

HILL, J. 'Muzicalizing' the other: shamanistic approaches to ethnic-class competition along the Upper Rio Negro. In: BARABAS, A. (Org.) Religiosidad y Resistencia Indígenas hasta el fin del Milenio. Quito: Abya-Yala, 1994.

HILL, J. \& WRIGHT, R. Time, narrative, and ritual: historical interpretations from an amazonian society. In: HILL, J. (Org.) Rethinking History and Myth: indigenous south american perspectives on the past. Urbana: University of Illinois Press, 1988.

HUGH-JONES, C. La fibre et la pulpe. L'Ethnographie, CXXI Tome LXXV (80):22-46, 1979.

JACKSON, J. Vaupés indigenous rights organizing and the emerging ethinic self. In: HILL, J. (Org.) South American Studies: discourses and the expression of personhood in south american inter-ethnic relations, 3:28-39, 1993.

JACKSON, J. Culture genuine and spurious: the politics of indianness in the Vaupés, Colombia. American Ethnologist, 22(1):2-27, 1995.

JACKSON, J. Preserving indian culture: shaman schools and ethno-education in the Vaupés, Colombia. Cultural Anthropology, 10(3):302-329, 1995.

JACOBI, P. Movimentos sociais urbanos no Brasil: reflexão sobre a literatura nos anos 70 e 80. BIB, (23):18-34, 1987.

JODELET, D. Les Representations Sociales. Paris: PUF, 1989.

JOVCHElOVITCH, S. \& GUARESCHI, P. (Orgs.) Textos em Representações Sociais. Petrópolis: Vozes, 1984.

KRACKE, W. Force and Persuasion: leadership in an amazonian society. Chicago: Chicago University Press, 1978.

KUMU, U. \& KENHIRI, T. Antes o Mundo não Existia. São Paulo: Cultura, 1968.

LACLAU, E. Os novos movimentos sociais e a pluralidade do social. Revista Brasileira de Ciências Sociais, 1(2):41-47, 1986.

LANNA, M. Reciprocidade e hierarquia. Revista de Antropologia, 39(1):111-144, 1996.

LANGDON, J. Saúde indígena: a lógica do processo de tratamento. Saúde em Debate, ed. especial, 1988.

LÉVI-STRAUSS, C. Le triangle culinaire. L'ArC, (26):19-29, 1968.

LÉVI-STRAUSS, C. O Pensamento Selvagem. São Paulo: Cia. Editora Nacional, 1976.

LÉVI-STRAUSS, C. (Org.) L'Identité. Paris: PUF, 1977.

MAGALHÃES, E. A Descentralização e o Terceiro Setor: entre o esvaziamento do Estado e o fortalecimento da sociedade civil. Brasília: SER/UnB, 1999.

MAUSS, M. Sociologia e Antropologia. São Paulo: EPU/Edusp, 1974. v.I e II. 
MAYBURY-LEWIS, D. Indian \& pro-indian organizations in Brazil. CuItural Survival Quartely, 8(4):19-21, 1984.

McCALLUM, C. Comendo com Txai, comendo como Txai: a sexualização de relações étnicas na Amazônia contemporânea. Revista de Antropologia, 40(1):109-147, 1997.

MELUCCI, A. The Playing Self: person and meaning in the planetary society. Cambridge: Cambridge University Press, 1996.

MONTEIRO, J. Raízes Históricas das Organizações Indígenas no Brasil. In: CONGRESSO INTERNACIONAL DA AHILA, XI, 1996, Liverpool.

MORÁn, E. A Ecologia Humana das Populações da Amazônia. Petrópolis: Vozes, 1990.

MOREIRA, I. \& MOREIRA, Â. Mitologia Tariano. Manaus: Ed. IBPC, 1994.

MURPHY, Y. \& MURPHY, R. Women of the Forest. New York: Columbia University Press, 1985.

NIMUENDAJÚ, K. Reconhecimento dos rios Içana, Ayari e Uaupés (1927). In: Textos Indigenistas. São Paulo: Loyola, 1982.

NOVAES, S. C. Jogo de Espelhos: imagens da representação de si através dos outros, 1990. Tese de Doutorado, São Paulo: Universidade de São Paulo.

OLIVEIRA, R. C. O Índio e o Mundo dos Brancos. a situação dos Tukuna do Alto Solimões. São Paulo: Difel, 1964.

OLIVEIRA, R. C. Identidade, Etnia e Estrutura Social. São Paulo: Pioneira, 1976.

OLIVEIRA, R. C. A Politização da Identidade e o Movimento Indígena. In: SEMINÁRIO IBEROAMERICANO DE ESTUDIOS INDIGENAS, I, 1987, Sevilha.

OLIVEIRA FILHO, J. P. Indigenismo e Territorialização: poderes, rotinas e saberes coloniais no Brasil contemporâneo. Rio de Janeiro: Contracapa, 1998.

OLIVEIRA FILHO, J. P. A Viagem de Volta: etnicidade, política e reelaboração cultural no Nordeste indígena. Rio de Janeiro: Contracapa, 1999.

ORLANDI, E. Uma retórica do oprimido: o discurso dos representantes indígenas. In: . Terra à Vista - Discurso do Confronto: Velho e Novo Mundo. São Paulo: Cortez/ Unicamp, 1990.

ORTNER, S. Está a mulher para o homem assim como a natureza está para a cultura? In: ROSALDO, R. \& LAMPHERE, L. A Mulher, a Cultura e a Sociedade. Rio de Janeiro: Paz e Terra, 1979.

ORTNER, S. Theory in anthropology since the sixties. In: (Org.) Culture/Power/ History. a reader in Contemporary Social Theory. Princeton: Princeton University Press, 1994.

ORTOLAN MATOS, MA. H. Histórias de Vida, Histórias de Líderes: trajetórias e perfis das lideranças do movimento indígena brasileiro. Projeto de pesquisa apresentado à Fapesp, 2000, Campinas (Mimeo.)

PALMEIRA, M. Voto: racionalidade ou significado? Revista Brasileira de Ciências Sociais, (20):26-30, 1992. 
PAlmeira, M. \& Goldman, M. Antropologia, Voto e Representação Política. Rio de Janeiro: Contracapa, 1996.

PALMEIRA, M. \& HeREDIA, B. Os comícios e a política de facções. In: Anuário Antropológico, 94:31-94, 1995.

PEREIRA, E. F. Movimento Indígena e Transformação Social no Alto Rio Negro, 2001. Monografia, Manaus: Universidade Federal do Amazonas.

PINTO, L. Pierre Bourdieu e a Teoria do Mundo Social. Rio de Janeiro: Ed. FGV, 2000.

PITKIN, H. The Concept of Representation. Berkeley: University of California Press, 1972.

POLLOCK, D. Personhood and Illness among the Culina of Western Brazil, 1985. Tese de Doutorado, New York: University of Rochester.

POUTIGNAT, P. \& STREIFF-FENART, J. Teorias da Etnicidade. São Paulo: Ed. Unifesp, 1998.

POZZoBon, J. Índios por opção. In: RICARDO, C. A. (Org.) Povos Indígenas no Brasil 1985/1995. São Paulo: Instituto Sócio-Ambiental, 1996.

RAMIREZ, H. Dicionário Baniwa Português. Manaus: Ed. Universidade do Amazonas, 2001.

RAMOS, A. O índio hiper-real. Revista Brasileira de Ciências Sociais, 28:5-14, 1995.

RAMOS, A. Convivência Interétnica no Brasil: os índios e a nação brasileira. Brasília: Ed. UnB, 1995. (Série. Antropologia)

REED, R. Federations of indians communities: strategies for grassroots development. Cultural Survival Quartely, 11(1):2-13, 1987.

REICHEL-DOLMATOFF, G. Desana: simbolismo de los indios Tukano del Vaupés. Bogotá: Procultura, 1986.

RETEL-LAURENTIN, A. (Org.) Etiologie et Perception de la Maladie dans les Sociétés Modernes et Traditionelles. Paris: Ed. L'Harmattan, 1987.

RIBEIRO, A. C. Movimentos sociais: caminhos para a defesa de uma temática ou os desafios dos anos 90. Ciências Sociais Hoje, 95-121, São Paulo: Vértice/Anpocs, 1991.

RICARDO, C. A. Jogo duro na cabeça do cachorro. In: (Ed.) Povos Indígenas do Brasil, 1987/88/ 89/90. Aconteceu Especial, 18:101-106, São Paulo: Cedi, 1991.

RIVIÉRE, P. Individual and society in Guiana: a comparative study of amerindian social organization. Cambridge: Cambridge University Press, 1984.

SÁ, C. Núcleo Central das Representações Sociais. Petrópolis: Vozes, 1996.

SABANA, F. A. Ciencias Naturales en la Mitologia Curripaco. Guainia: Ed. Fundación Etnollano/Programa Fondo Amazonico/Coama, 1997.

SAHLINS, M. Cultura e Razão Prática. São Paulo: Zahar, 1979.

SANTOS, A. M. \& LIMA, M. Medicina tradicional e ocidental no Alto Rio Negro: o papel dos rezadores em S. Gabriel da Cachoeira/AM. In: BUCHILlET, D. Medicinas Tradicionais e Medicina Ocidental na Amazônia. Belém: Ed. Cejup/MPEG, 1991. 
SANTOS, M. Por uma geografia das redes. In: A Natureza do Espaço: técnica e tempo; razão e emoção. São Paulo: Hucitec, 1999.

SEEGER, A. DA MATTA, R. \& VIVEIROS DE CASTRO, E. A Construção da pessoa nas sociedades indígenas brasileiras. In: OLIVEIRA FILHO, J. P. (Org.) Sociedades Indígenas e Indigenismo no Brasil. Rio de Janeiro: Marco Zero, 1987.

SEYFERTH, G. Etnicidade e cidadania: algumas considerações sobre as bases étnicas da mobilização política. Boletim do Museu Nacional, (42):1-16, 1983.

SILVA, M. C. Metamorfoses da Amazônia, 1997. Tese de Doutorado, Campinas: IFCH/ Unicamp.

SMITH, R. C. A. Search for unity within diversity. Cultural Survival Quartely, 8(4):6-14, 1984.

SPINK, M. J. Práticas Discursivas e Produção de Sentidos no Cotidiano: aproximações teóricas e metodológicas. São Paulo: Cortez, 1999.

THOMAS, D. Order without Government: the society of the Pemon Indians of Venezuela. Urbana: University of Illinois Press, 1982.

TORRES LABORDE, A. Mito y Cultura entre los Barasana. Bogotá: Ed. Universidad de los Andes, 1969.

TOURRAINE, A. An introduction to the study of social movements. Social Research, 52(4):749-788, 1985.

UMUSI, P. \& KEHIRI, T. Antes o Mundo não Existia. São Paulo: Cultura, 1968.

VALLADARES, L. \& BOSCHI, R. Problemas teóricos na análise dos movimentos sociais.In: ENCONTRO ANUAL DA ANPOCS, VII, 1981, Friburgo.

VERÓN, E. Quand lire c'est faire: L'enonciation dans le discours de la presse écrite. Semiotique II. Paris: Irep, 1983.

VIEIRA, P. A problemática ambiental e as ciências sociais no Brasil. In: HOGAN, D. \& VIEIRA, P. F. (Orgs.) Dilemas Socioambientais e Desenvolvimento Sustentável. Campinas: Ed. Unicamp, 1985.

VIOLA, E. \& LEIS, H. Desordem global da biosfera e nova ordem internacional: o papel organizador do ecologismo. In: ENCONTRO ANUAL DA ANPOCS, XIII (GT ECOLOGIA POLÍTICA E SOCIEDADE), 1989, Caxambu.

VIVEIROS DE CASTRO, E. Autodeterminação indígena como valor. In: Anuário Antropológico/81. Fortaleza: Ed. Universidade Federal do Ceará/Tempo Brasileiro, 1983.

VIVEIROS DE CASTRO, E. Alguns aspectos da afinidade no dravidianato amazônico. In: VIVEIROS DE CASTRO, E. \& CARNEIRO DA CUNHA, M. (Orgs.) Etnologia e História Indígena. São Paulo: Ed. NHII/USP/Fapesp, 1993.

VIVEIROS DE CASTRO, E. Etnologia brasileira. In: MICELI, S. (Org.) O que Ler na Ciência Social Brasileira (1970-1995). Antropologia. v.I. São Paulo: Sumará/ Anpocs/Capes, 2000.

WHITE, $\mathrm{K}$. The sociology of health and illness: feminist approaches to the sociology of health. Current Sociology, 39(2):50-70, 1998. 
WRIGHT, R. Anthropological presuppositions of indigenous advocacy. Annual Review of Anthropology, 17:365-390, 1988.

ZEMPLÉNI, A. La maladie et ses causes. L'Ethnographie, LXXXI (96-97):13-44, 1985.

ZEMPLÉNI, A. Entre 'sickness' et 'illness': de la socialisation e l'individualisation de la 'Maladie'. Social Science and Medicine, 27(11):1171-1182, 1988.

ZORNOSA, Y. Colombian Indian Organization. Cultural Survival Quartely, 8(4):66-67, 1984.

\section{Documentos Consultados}

ASSOCIAÇÃO DAS COMUNIDADES INDÍGENAS DO RIO AIARI/ACIRA. Relatório de Atividades. Comunidade de Canadá, 1999.

ASSOCIAÇÃO DAS COMUNIDADES INDÍGENAS DO RIO AIARI/ACIRA. Relatório de Assembléia Eletiva. Comunidade de Canadá, 2000.

ASSOCIAÇÃO DOS AGENTES INDÍGENAS DE SAÚDE DO ALTO RIO NEGRO/AAISARN. Ata da III Assembléia Anual. S. Gabriel da Cachoeira, 1998.

ASSOCIAÇÃO DOS AGENTES INDÍGENAS DE SAÚDE DO ALTO RIO NEGRO/AAISARN. Ata da IV Assembléia Anual. S. Gabriel da Cachoeira, 1999.

ASSOCIAÇÕES INDÍGENAS DO IÇANA/AIARI/XIÉ. Relatório da Primeira Assembléia Regional do Içana/Aiari/Xié. Tunuí, 2000.

As Faces Escuras do Indigenismo Missionário com as Modernas Formas de Dominação Colonial. Documento produzido pelas Organizações Indígenas em abril de 2000. In: Povos indígenas no Brasil, 1996/2000. São Paulo: Instituto Sócio-Ambiental, 2000.

As Muitas Faces de uma Guerra. CIMI interpreta comemorações dos 500 anos e critica movimento indígena. In: Povos indígenas no Brasil, 1996/2000. São Paulo: Instituto Sócio-Ambiental, 2000.

CÂMARA MUNICIPAL DE S. GABRIEL DA CACHOEIRA. Ata de Reunião Ordinária. In: RICARDO, C. A. Povos Indígenas do Brasil, 1996/2000. São Paulo: Instituto SócioAmbiental, 2000.

COORDENAÇÃO DAS ORGANIZAÇÕES INDÍGENAS DA AMAZÔNIA BRASILEIRA/COIAB. Relatório Final do Encontro Macro Regional preparatório para a III Conferência Nacional de Saúde Indígena. Manaus, 2001.

COORDENAÇÃO DAS ORGANIZAÇÕES INDÍGENAS DA AMAZÔNIA BRASILEIRA/COIAB. Encontro das Organizações Indígenas Conveniadas com a Funasa. Resultados $e$ desafios do programa dos Distritos Sanitários Especiais Indígenas no atendimento da saúde dos Povos Indígenas. Manaus, 2001.

FEDERAÇÃO DAS ORGANIZAÇÕES INDÍGENAS DO RIO NEGRO/FOIRN. Relatório da XIII Reunião do Conselho Administrativo da Foirn/CAF. S. Gabriel da Cachoeira, 1999.

FEDERAÇÃO DAS ORGANIZAÇÕES INDÍGENAS DO RIO NEGRO/FOIRN. Relatório da XIV. Reunião do Conselho Administrativo da Foirn/CAF. S. Gabriel da Cachoeira, 2000. 
FEDERAÇÃO DAS ORGANIZAÇÕES INDÍGENAS DO RIO NEGRO/FOIRN. Relatório da XVI Reunião do Conselho Administrativo da Foirn/CAF. S. Gabriel da Cachoeira, 2001.

ISA/FOIRN, Comunidades Indígenas do Alto e Médio Rio Negro - Banco de dados da demarcação. São Gabriel da Cachoeira, 1997.

MINISTÉRIO DA SAÚDE/FUNASA. Relatório Final da III Conferência Nacional de Saúde dos Povos Indígenas. Brasília, maio de 2001.

MINISTÉRIO DA SAÚDE/FUNASA. Plano Distrital do Distrito Sanitário Especial Indígena do Rio Negro. S. Gabriel da Cachoeira, 2001.

ORGANIZAÇÃO INDÍGENA DA BACIA DO IÇANA/OIBI. Relatório da V Assembléia Geral. Tucumã Rupita, 1997.

ORGANIZAÇÃO INDÍGENA DA BACIA DO IÇANA/OIBI. Estatuto da Oibi. S. Gabriel da Cachoeira, 1997.

ORGANIZAÇÃO INDÍGENA DA BACIA DO IÇANA/OIBI. Relatório de Treinamento da Oibi. Tucumã Rupita, 1999.

ORGANIZAÇÃO INDÍGENA DA BACIA DO IÇANA/OIBI. Plano de trabalho para o triênio 2001-2003. Tucumã Rupita, 2000.

ORGANIZAÇÃO INDÍGENA DA BACIA DO IÇANA/OIBI. Relatório de gestão da OIB. Tucumã Rupita, 2000.

ORGANIZAÇÃO INDÍGENA DA BACIA DO IÇANA/OIBI. Relatório de gestão da OIB. Tucumã Rupita; 2001.

ORGANIZAÇÃO INDÍGENA DOS CURIPACO DO ALTO IÇANA/OICAI. Relatório de Treinamento. Comunidade de Panã-Panã, 2000. 
Formato: $21 \times 26 \mathrm{~cm}$

Tipologia: Egyptian 505 BT/Baker Signet BT

Papel: Print Max $90 \mathrm{~g} / \mathrm{m}^{2}$ (miolo)

Cartão Supremo $250 \mathrm{~g} / \mathrm{m}^{2}$ (capa)

Fotolitos: Laser vegetal (miolo)

Engenho \& Arte Editoração Gráfica Ltda. (capa)

Impressão e acabamento: Imprinta Gráfica e Editora Ltda.

Rio de Janeiro, novembro de 2003.

Não encontrando nossos títulos em livrarias, contactar a EDITORA FIOCRUZ:

Av. Brasil, $4036-1^{e}$ andar - sala 112 - Manguinhos

21040-361 - Rio de Janeiro - RJ

Tel.: (21) 3882-9039 e 3882-9041

Telefax: (21) 3882-9006

http://www.fiocruz.br/editora

e-mail: editora@fiocruz.br 